ISSN 2308-152X (Print)

ISSN 2313-6197 (Online)

DOI: $\quad 10.22378 / 2313-6197.2021-9-2$

\title{
ЗОЛОТООРДЫНСКОЕ ОБОЗРЕНИЕ
} 2021. Том 9, № 2

\section{ZOLOTOORDYNSKOE OBOZRENIE $=$ GOLDEN HORDE REVIEW}

\author{
2021 , vol. 9 , no. 2
}

http://goldhorde.ru

E-mail: mail@goldhorde.ru

(ㄷ ГБУ «Институт истории им. Ш. Марджани Академии наук Республики Татарстан», 2021 


\title{
ЗОЛОТООРДЫНСКОЕ ОБОЗРЕНИЕ
}

\author{
Научный журнал
}

«Золотоордынское обозрение» - это рецензируемый научный журнал, на страницах которого находят отражение научные публикации конкретно-исторического, историографического и источниковедческого характера, охватывающие все области изучения истории Золотой Орды и татарских ханств.

Журнал печатает ранее неопубликованные, оригинальные статьи российских и зарубежных авторов на русском и английском языках. «Золотоордынское обозрение» уделяет также большое внимание обсуждению новых научных изданий (монографий, академических публикаций), которое осуществляется в формате рецензий.

Журнал входит в Перечень российских рецензируемых научных журналов, в которых должны быть опубликованы основные научные результаты диссертаций на соискание ученых степеней доктора и кандидата наук по научным специальностям:

07.00.02 - Отечественная история (исторические науки), 07.00.09 - Историография, источниковедение и методы исторического исследования (исторические науки).

Размещение и индексирование журнала в международных реферативных и полнотекстовых базах данных: Scopus, Web of Science (ESCI), Directory of Open Access Journals (DOAJ), Ulrich's Periodicals Directory, ERIH PLUS, AcademicKeys, ResearchBib, WorldCat, Google Scholar, EBSCO, Open Academic Journals Index (OAJI), Russian Science Citation Index (RSCI), Российский индекс научного цитирования (РИНЦ), Научная электронная библиотека открытого доступа КиберЛенинка.

Журнал является участником партнерств: CrossRef и профессионального сообщества «Ассоциация научных редакторов и издателей (АНРИ)»

Наименование органа, Свидетельство о регистрации

зарегистрировавшего

СМИ ПИ № ФС77-54682 от 9 июля 2013 г.

издание:

Журнал основан:

выдано Роскомнадзором

ISSN

2013 г.

Периодичность:

ISSN 2308-152X (Print), ISSN 2313-6197 (Online)

Учредитель и издатель:

4 раза в год

Государственное бюджетное учреждение «Институт

истории им. Ш. Марджани Академии наук Республики

Татарстан» (420111, г. Казань, ул. Батурина, 7А)

Адрес редакции:

420111, г. Казань, ул. Батурина, 7А

Типография:

Издательский дом «Логос»

Сайт:

http://goldhorde.ru

E-mail:

Тел./факс

mail@goldhorde.ru

(843) 2928482 (приемная), 2920019

Подписка:

Подписной индекс П7934. Оформить подписку можно как в отделениях почтовой связи, так и в режиме онлайн на сайте podpiska.pochta.ru 


\section{GOLDEN HORDE REVIEW}

\section{Academic Journal}

"Zolotoordynskoe obozrenie = Golden Horde Review" is a peer-reviewed academic journal publishing articles of historical, historiographical and source-researching nature, covering all fields of study of the history of the Golden Horde and the Tatar khanates.

The journal publishes unpublished and original articles by Russian and foreign authors in Russian and English. "Zolotoordynskoe obozrenie = Golden Horde Review" also pays considerable attention to the discussion of new researches (monographs and other academic publications) in the form of reviews.

The journal is included in the List of Russian peer-reviewed scientific journals publishing the main scientific results of dissertations for the academic degrees of a doctor and candidate of sciences in scientific specialties: 07.00.02 - Domestic history (historical studies), 07.00.09 - Historiography, source study and methods of historical research (historical studies).

The journal is indexed by: Scopus, Web of Science (Emerging Sources Citation Index), Directory of Open Access Journals (DOAJ), Ulrich's Periodicals Directory, ERIH PLUS, AcademicKeys, ResearchBib, WorldCat, Google Scholar, EBSCO, Open Academic Journals Index (OAJI), Russian Science Citation Index (RSCI), Russian Science Citation Index Database, CyberLeninka.

The journal is a participant of partnerships: CrossRef and Association of scientific editors and publishers (ASEP).

Name of the authority that registered the periodical:

The journal was founded:

ISSN

Publication frequency:

Founder and publisher:

Editorial address:

Press:

Web-site:

E-mail:

Tel./fax:

Subscription:
Roskomnadzor, certificate of registration of the media

No. PI FS77-54682, issued on July 9, 2013

2013

ISSN 2308-152X (Print), ISSN 2313-6197 (Online)

4 times a year

State Budgetary Institution "Marjani Institute of History

of Tatarstan Academy of Sciences"

(420111, Kazan, Baturin Str., 7A)

420111, Kazan, Baturin Str., 7A

Publishing house "Logos"

http://goldhorde.ru

mail@goldhorde.ru

(843) 2928482 (receiving office), 2920019

Subscription index $\mathbf{\Pi 7 9 3 4}$. The subscription can be made both in the post offices and online at podpiska.pochta.ru 


\section{ГЛАВНЫЙ РЕДАКТОР}

Миргалеев Ильнур Мидхатович, к.и.н., руководитель Центра исследований Золотой Орды и татарских ханств им. М.А. Усманова Института истории им. Ш. Марджани АН РТ (Казань, Российская Федерация)

\section{РЕДАКЦИОННАЯ КОЛЛЕГИЯ}

Салихов Радик Римович, д.и.н., директор Института истории им. Ш.Марджани АН РТ, академик АН РТ (Казань, Российская Федерация)

Хакимов Рафаиль Сибгатович, д.и.н., научный руководитель Института истории им. Ш. Марджани АН РТ, вице-президент АН РТ, академик АН РТ (Казань, Российская Федерация)

Трепавлов Вадим Винцерович, д.и.н., главный научный сотрудник Института российской истории РАН, руководитель Центра истории народов России и межэтнических отношений (Москва, Российская Федерация) Иштван Вашари, Ph.D. (история), профессор Университета им. Лоранда Этвеша (Будапешт, Венгрия)

Виктор Спиней, Ph.D. (история), профессор, вице-президент Румынской академии, почетный директор Института археологии (Яссы, Румыния)

Карпов Сергей Павлович, д.и.н., профессор, академик РАН, президент исторического факультета Московского государственного университета им. М.В. Ломоносова (Москва, Российская Федерация)

Никола Ди Козмо, Ph.D. (история), профессор исследований Восточной Азии, Институт перспективных исследований (Принстон, Нью Джерси, США)

Дариуш Колодзейчик, Ph.D. (история), профессор, директор Института истории Варшавского университета (Варшава, Польша)

Зайцев Илья Владимирович, д.и.н., ведущий научный сотрудник Института российской истории РАН и Института востоковедения РАН (Москва, Российская Федерация)

Крамаровский Марк Григорьевич, д.и.н., ведущий научный сотрудник Отдела Востока Государственного Эрмитажа, куратор центрально-азиатских коллекций (Санкт-Петербург, Российская Федерация)

Чарльз Гальперин, Ph.D. (история), научный сотрудник Института исследований России и Восточной Европы, Индианский университет (Блумингтон, США)

Мари Фаверо-Думенжу, Ph.D. (история), научный сотрудник исторического факультета Оксфордского университета (Оксфорд, Великобритания)

Горский Антон Анатольевич, д.И.Н., профессор МГУ им.М.В. Ломоносова, ведущий научный сотрудник Института российской истории РАН (Москва, Российская Федерация)

Александар Узелац, Ph.D. (история), научный сотрудник Института истории (Белград, Сербия)

Иванов Владимир Александрович, д.и.Н., профессор Башкирского государственного педагогического университета им. М.Акмуллы (Уфа, Российская Федерация)

Муминов Аширбек Курбанович, д.и.н., профессор, Евразийский Национальный университет им. Л.Н. Гумилева (Астана, Казахстан)

Почекаев Роман Юлианович, д.и.н., доцент, профессор, заведующий кафедрой теории и истории права и государства Национального исследовательского университета «Высшая школа экономики» в СанктПетербурге (Санкт-Петербург, Российская Федерация)

Мария Иванич, Ph.D. (история), руководитель кафедры алтаистики и тюркологической исследовательской группы Академии наук Венгрии, Университет Сегеда (Сегед, Венгрия)

Тимоти Мэй, Ph.D. (история), профессор истории Центральной Евразии, университет Северной Джорджии (США)

Борис Черкас, д.и.н., ведущий научный сотрудник Института истории Украины НАН Украины (Киев, Украина)

Аксанов Анвар Васильевич, к.и.н., старший научный сотрудник Института истории им. Ш. Марджани АН РТ (Казань, Российская Федерация)

\section{РЕДАКЦИЯ}

Редакторы английских текстов: Роман Хаутала, Ph.D. (история), старший научный сотрудник Института истории им. Ш. Марджани АН РТ; доцент гуманитарного фракультета университета Оулу (Оулу, Финляндия); Стивен Поу, Ph.D. (история), Центрально-Европейский университет (Будапешт, Венгрия)

Литературный редактор: Сайфетдиновна Эльмира Гаделзяновна, к.и.н., старший научный сотрудник Института истории им. Ш. Марджани АН РТ (Казань, Российская Федерация)

Корректор: Галимов Тэймур Рустэмович, к.и.н., старший научный сотрудник Института истории им. Ш. Марджани АН РТ (Казань, Российская Федерация)

Технический редактор, ответственный секретарь: Гиниятуллина Люция Сулеймановна, младший научный сотрудник Института истории им. Ш. Марджани АН РТ (Казань, Российская Федерация) 


\section{CHIEF EDITOR}

Il'nur M. Mirgaleev, Cand. Sci. (History), Head of the Usmanov Center for Research on the Golden Horde and Tatar Khanates, Marjani Institute of History of Tatarstan Academy of Sciences (Kazan, Russian Federation)

\section{EDITORIAL BOARD}

Radik R. Salikhov, Dr. Sci. (History), Director, Marjani Institute of History of Tatarstan Academy of Sciences, Academician of the Tatarstan Academy of Sciences (Kazan, Russian Federation)

Rafail' S. Khakimov, Dr. Sci. (History), Academic Director, Marjani Institute of History of Tatarstan Academy of Sciences (TAS), Vice-president of TAS, Academician of the Tatarstan Academy of Sciences (Kazan, Russian Federation)

Vadim V. Trepavlov, Dr. Sci. (History), Chief Research Fellow, Institute of Russian history, Russian Academy of Sciences, Chief of the Center of History of the Peoples of Russia and Interethnic Relations (Moscow, Russian Federation)

István Vásáry, Ph.D. (History), Professor, Eötvös Loránd University (Budapest, Hungary)

Victor Spinei, Ph.D. (History), Professor, Vice-president of the Romanian Academy, Honorary Director of the Institute of Archaeology (lasi, Romania)

Sergey P. Karpov, Dr. Sci. (History), Professor, Academician of the Russian Academy of Sciences, President of the Historical Faculty of the Lomonosov Moscow State University (Moscow, Russian Federation)

Nicola Di Cosmo, Ph.D., Professor of East Asian Studies, Institute for Advanced Study (Princeton, New Jersey, USA)

Dariusz Kołodziejczyk, Ph.D. (History), Professor, Director of the Institute of History, University of Warsaw (Warsaw, Poland)

Il'ya V. Zaytsev, Dr. Sci. (History), Leading Research Fellow, Institute of Russian History, Institute of Oriental Studies, Russian Academy of Sciences (Moscow, Russian Federation)

Mark G. Kramarovsky, Dr. Sci. (History), Leading Research Fellow, Oriental Department, State Hermitage Museum, Curator of Central Asian Collection (St. Petersburg, Russian Federation)

Charles J. Halperin, Ph.D., Research Associate, Russian and East European Institute, Indiana University (Bloomington, USA)

Marie Favereau Doumenjou, Ph.D. (History), Research Associate, Faculty of History, Oxford University (Oxford, England)

Anton A. Gorsky, Dr. Sci. (History), Professor, Faculty of History, Lomonosov Moscow State University, Leading Research Fellow, Institute of Russian History, Russian Academy of Sciences (Moscow, Russian Federation)

Aleksandar Uzelac, Ph.D. (History), Research Fellow, Institute of History (Belgrade, Serbia)

Vladimir A. Ivanov, Dr. Sci. (History), Professor, Bashkir State Pedagogical University named after M. Akmulla (Ufa, Russian Federation)

Ashirbek Muminov, Dr. Sci. (History), Professor, L.N.Gumilyov Eurasian National University (Astana, Kazakhstan)

Roman Yu. Pochekaev, Dr. Sci. (History), Associate professor, Professor, Head of the Department of theory and history of law and state, National Research University Higher School of Economics (St. Petersburg, Russian Federation)

Mária Ivanics, Ph.D. (History), Professor, Head of the Department of Altaic Studies and Turcological Research Group of the Hungarian Academy of Sciences, University of Szeged (Szeged, Hungary)

Timothy May, Ph.D., Professor of Central Eurasian History, University of North Georgia (USA)

Boris V. Cherkas, Dr. Sci. (History), Leading Research Fellow, Institute of History of Ukraine, National Academy of Sciences of Ukraine (Kyiv, Ukraine)

Anvar V. Aksanov, Cand. Sci. (History), Senior Research Fellow, Marjani Institute of History of Tatarstan Academy of Sciences (Kazan, Russian Federation)

\section{EDITORIAL OFFICE}

English texts' editors: Roman Hautala, Ph.D. (History), Senior Research Fellow, Marjani Institute of History of Tatarstan Academy of Sciences; Docent at the Faculty of Humanities, University of Oulu (Oulu, Finland); Stephen Pow, Ph.D. (History), Central European University (Budapest, Hungary)

Literary editor: Elmira G. Sayfetdinova, Cand. Sci. (History), Senior Research Fellow, Marjani Institute of History of Tatarstan Academy of Sciences (Kazan, Russian Federation)

Corrector: Teymur R. Galimov, Cand. Sci. (History), Senior Research Fellow, Marjani Institute of History of Tatarstan Academy of Sciences (Kazan, Russian Federation)

Technical editor, Executive secretary: Lyutsiya S. Giniyatullina, Research Fellow, Marjani Institute of History of Tatarstan Academy of Sciences (Kazan, Russian Federation) 


\section{СОДЕРЖАНИЕ}

\section{Оригинальные статьи}

Селезнёв Ю.В. К вопросу о происхождении полководца Бурундая

Hautala R. The Loss and Reacquisition of Caffa: The Status of the Genoese Entrepôt within the Borders of the Golden Horde

Schamiloglu U. Reflections on the Islamic Literature of the Golden Horde:

On the Occasion of the Publication of the Qalandar-nāme

Иванов В.А. Седентаризация средневековых кочевников Восточной Европы: понимание и проявление

Мухаметшин Д.Г. Денежное обращение Булгарского улуса во второй половине XIV в

Полехов С.В. Ярлык хана Токтамыша польскому королю Владиславу II Ягайлу 1393 года. Проблема

происхождения древнерусского текста

Адыгамов Р.К. Булгарские и золотоордынские богословы и богословские источники через призму «Мустафад ал-ахбар...» Ш. Марджани

Аксанов А.В. Промедление Ивана IV при взятии Казани: проявление иносказательности средневековых текстов и реальной поведенческой практики

Адамов А.А. Кучумово городище - столичный город в Сибири или исторический миф (археологические факты и исторические предположения)

Маслюженко Д.Н. «Сибирское царство» как концепт русских летописей и посольских документов второй половины XVI века

Бахтин А.Г. Жизнь и смерть мангытского карачи-бека Дивея

Мустакимов И.А., Ханнанова Г.М. Ханский указ о назначении муфтия: мусульмане под властью волжских калмыков

Антонов И.В. Рецензия на книгу: Злыгостев В.А. Герои «Сокровенного сказания» 


\section{CONTENTS}

\section{Original papers}

Seleznev Ju.V. On the Origin of the Commander Burundai

Hautala R. The Loss and Reacquisition of Caffa: The Status of the Genoese Entrepôt within the Borders of the Golden Horde

Schamiloglu U. Reflections on the Islamic Literature of the Golden Horde:

On the Occasion of the Publication of the Qalandar-nāme

Ivanov V.A. Sedentarization of the Medieval Nomads of Eastern Europe: Understandings and Manifestations

Mukhametshin D.G. Money Circulation in the Bulgar Ulus in the second half of fourteenth century

Polekhov S.V. The Yarliq of Tokhtamish Khan

to King Władysław II Jagiełło of Poland:

The Problem the Old Russian Text's Origins

Adygamov R.K. The Bulgar and Golden Horde's Theologians and Theological Sources through the Prism of Sh. Marjani's "Mustafad al-akhbar..."

Aksanov A.V. Ivan IV's Postponement of the Assault on Kazan:

A Manifestation of the Allegorical Nature of Medieval Texts and Real Behavioral Practice

Adamov A.A. The Kuchum Settlement: The Capital of Siberia or a Historical Myth (Archaeological Facts and Historical Assumptions)

Maslyuzhenko D.N. The "Siberian Tsardom" as a Concept in Russian Chronicles and Ambassadorial Documents of the second half of the sixteenth century

Bakhtin A.G. The Life and Death of the Manghit Qarachi-bek, Divei

Mustakimov I.A., Khannanova G.M. Khan's Decree on the Appointment of the Mufti: Muslims under the Rule of the Volga Kalmyks

Antonov I.V. Book Review: Zlygostev V.A. Geroi

"Sokrovennogo skazaniya" [Heroes of the "Secret History"] 438 


\title{
ОРИГИНАЛЬНЫЕСТАТЬИ
}

\section{К ВОПРОСУ О ПРОИСХОЖДЕНИИ ПОЛКОВОДЦА БУРУНДАЯ}

\author{
Ю.В. Селезнёв \\ Воронежский государственный университет \\ Воронеж, Российская Федераџия \\ orda1359@mail.ru
}

Цель исследования: в данной работе основное внимание уделено происхождению видного ордынского полководца времени завоевательных походов монголов, активного участника западного семилетнего похода, разгромившего главные силы владимирского княжества на реке Сить - эмира Бурундая. Вопросы происхождения полководцев времени становления Монгольской империи и Золотой Орды представляют собой не простую задачу. Синхронные и поздние источники несут информацию в основном о родственниках Чингиз-хана и его ближайших сподвижниках. Биографии же многих участников западного похода реконструируются с большим трудом: о них практически ничего не известно, либо встречается крайне запутанная, обрывочная и противоречивая информация. Именно к таким фигурам, оставшимся в тени Чингиз-хана, его детей и внуков, можно отнести эмира Бурундая. Известный монгольский полководец времени завоеваний XIII века Бурундай активно проявил себя при завоевании Восточной Европы, в походах на Венгрию и Польшу. В исследовательской литературе фигуре Бурундая уделено определенное внимание. Однако он упоминается эпизодически в связи с судьбами и жизнеописаниями русских князей, и целостной его биографии или исторического портрета не составлено. Обусловлено это во многом состоянием источникового материала: его информация не дает нам четкого представления об одном из ярких полководцев времени монголо-татарских завоеваний. В то же время, целостная картина жизни и деятельности отдельных полководцев и военачальников времени монголотатарских завоеваний, реконструированная, исходя из информации источников, может дать нам ценную информацию для обобщений о военном искусстве Монгольской империи и Джучиева улуса, его развитии в исторической перспективе, влиянии на вооружение и ведение военных действий соседних стран и народов.

Материалы исследования: основными источниками сведений о Бурундае являются эпические и хроникальные произведения монгольского и китайского происхождения, персидские и русские летописи. Дополнительную косвенную информацию несет актовый и археологический материал.

Результаты исследования и научная новизна: в статье делается вывод о том, что среди упоминаемых в письменных источниках лиц наиболее предпочтительной фигурой на роль брата Боорчу можно считать Огелен-черби. Соответственно, его же следует признать отцом Буралтая. Последний, по всей вероятности, родился около 1200 г.

Ключевые слова: Джучиев улус, Монгольская империя, поход Батыя, Бурундай 
Для цитирования: Селезнёв Ю.В. К вопросу о происхождении полководца Бурундая // Золотоордынское обозрение. 2021. T. 9, № 2. С. 236-246. DOI: 10.22378/23136197.2021-9-2.236-246

\title{
ON THE ORIGIN OF THE COMMANDER BURUNDAI
}

\author{
Ju.V. Seleznev \\ Voronezh State University \\ Voronezh, Russian Federation \\ orda1359@mail.ru
}

\begin{abstract}
Research objectives: This work focuses on the origins of Amir Buruldai (also recorded as Burundai). He was an eminent military leader of the Horde during the time of the Mongol conquests and an active participant in the seven-year-long Western campaign, defeating the main forces of the Principality of Vladimir at the Sit' River. Research on the origin of the generals living at the time of formation of the Mongol Empire and the Golden Horde is not a simple task. Synchronous and late sources carry information mainly about the relatives of Chinggis Khan and his closest associates. Biographies of many participants of the Western campaign are reconstructed with great difficulty; almost nothing is known about them, or extremely confusing, fragmentary, and contradictory information is found. Amir Buruldai can be included among such figures, left in the shadow of Chinggis Khan, his children, and grandchildren. A famous Mongol commander, Buruldai is distinguishable in the sources during the conquest of Eastern Europe and the campaigns against Hungary and Poland. In the research literature, the figure of Burundai is given some attention. However, he is mentioned occasionally in connection with the fate and lives of Russian princes, and a complete biography or historical portrait was not made. This is largely due to the state of the source material. Its information does not give us a clear picture of one of the more illustrious generals of the time of the Mongol-Tatar conquests. At the same time, a holistic picture of the life and activities of individual military commanders during the Mongol conquests, reconstructed on the basis of written sources, can give us valuable information for generalizations about warfare waged by the Mongol Empire and the ulus of Jochi, its development in a historical perspective, and the impact on the development of weapons and warfare among neighboring countries and peoples.

Research materials: The main sources of information about Burundai are epic and chronicle works of Mongolian and Chinese origin, as well as Persian and Russian chronicles. Additional and indirect information is provided by official documentation and archaeological material.

Results and novelty of the research: This article concludes that among the persons mentioned in written sources, Ogelen-cherbi can be considered the most plausible figure for Boorchu's brother. Accordingly, he is to be recognized as the father of Buraldai. The latter, in all probability, was born in about 1200.
\end{abstract}

Keywords: Ulus of Jochi, Mongol Empire, Batu's Campaign, Burundai

For citation: Seleznev Ju.V. On the Origin of the Commander Burundai. Zolotoordynskoe obozrenie=Golden Horde Review. 2021, vol. 9, no. 2, pp. 236-246. DOI: 10.22378/2313-6197.2021-9-2.236-246 
Появление на карте мира державы Чингиз-хана, а затем стремительный рост Монгольской империи за счет военных завоеваний монголо-татар привели к изменению геополитической ситуации в огромном Евразийском регионе. Владение старшего сына Чингиз-хана - Улус Джучи, сначала как составная часть Монгольской империи, а затем как самостоятельная политическая единица, оказывал сильнейшее влияние на соседние страны и народы. Большую роль в расширении владений Джучидов сыграли военные кампании внука Чингиз-хана Батыя. Именно с его деятельностью связаны завоевательные походы в Европу, завоевание Волжской Булгарии и Руси. Однако под его командованием находились выдающиеся и талантливые военачальники, роль которых в боевых операциях того времени оказалась в тени знаменитого внука Чингиз-хана. Именно к таким полководцам следует отнести эмира Бурундая, известия о котором отложились в ряде источников того времени.

Имя монгольского эмира Бурундая тесно связано с покорением Волжской Булгарии, Половецкой степи, русских княжеств и вторжениями в Польшу в XIII столетии. Именно в связи с этими событиями к его личности существует определённое внимание в исследовательской литературе. Завоевание Руси и установление ордынского ига обусловило упоминание Бурундая в работах Н.М. Карамзина, Н.И. Костомарова, В.Т. Пашуто, Л.Н. Гумилёва, А.А. Астайкина $[2 ; 8 ; 9 ; 15 ; 19$, с. $154-157 ; 23$, с. $245 ; 24 ; 25$, с. 220]. В рамках изменений этнической и геополитической ситуации в причерноморском регионе упоминаются действия ордынского эмира в работах А.О. Добролюбского и Н.Д. Русеева, а также в обширном историко-географическом труде В.Л. Егорова $[10 ; 11]$. Непосредственно посвященная монгольским вторжениям в Польшу работа В.М. Шетеля также не могла обойти стороной личность Бурундая [38]. Кроме того, различные подробности монголо-татарского нашествия на Восточную Европу в конце 1230 - начале $1240-$ х гг. рассмотрены в обширной исследовательской литературе $[5 ; 6 ; 7 ; 8 ; 9 ; 13 ; 14 ; 16 ; 17 ; 20 ; 21$; $31 ; 32 ; 33 ; 34 ; 35 ; 36 ; 39 ; 40 ; 41]$.

Тем не менее эпизодические упоминания о Бурундае в исследовательской литературе не дают нам четкого представления об одном из ярких полководцев времени монголо-татарских завоеваний: его подробная биография или исторический портрет не составлены. Обусловлено это во многом состоянием источникового материала. Если о родственниках Чингиз-хана, его ближайших сподвижниках известно довольно много, то о судьбе многих участников западного похода не известно ничего вовсе, либо встречается крайне запутанная и обрывочная информация. Именно к таким фигурам, оставшимся в тени внуков Чингиз-хана, можно отнести Бурундая.

Между тем, по возможности целостная картина жизни и деятельности отдельных полководцев и военачальников времени монголо-татарских завоеваний может дать ценную информацию о военном искусстве Монгольской империи и Джучиева улуса, его развитии в исторической перспективе, влиянии на вооружение и ведение военных действий соседних стран и народов.

В данной работе основное внимание уделено происхождению видного монголо-татарского полководца времени завоевательных походов монголов.

В рассматриваемый период источники фиксируют следующие события из жизни Бурундая. Во-первых, это победа войск Бурундая в битве на р. Сить 5 марта 1238 г., в которой были разгромлены резервные войска Владимиро- 
Суздальской Руси и убит её глава - князь Юрий Всеволодович [4, с. 234; 22 , с. 74-77; 26, стб. 370], что, наряду с падением столицы княжества - г. Владимира, ставило вопрос о военно-политическом покорении страны. Таким образом, именно тумену Бурундая удалось решить одну из стратегических задач вторжения. Надо полагать, что именно после битвы на р. Сить Бурундай получает почетное монгольское звание бахадур (батур).

Бурундай активно участвовал и, возможно, командовал завоеванием Крыма в 1239 г. Преследование половцев-кипчаков и их разгром в Крыму являлось важной оперативной задачей [14;20;21].

Стратегическая задача другого вторжения, уже в Венгрию, решалась в битве у р. Шайо. По всей вероятности, Бурундай осуществлял общее руководство сражением, а, значит, разрабатывал его план и ставил оперативные и тактические задачи [30, с. 37]. Разгром венгерских войск открыл путь монголо-татарским всадникам вглубь страны.

В конце 1250-х гг. Бурундай и его войска были передислоцированы на крайнюю западную границу Монгольской империи. Его победоносные походы на Польшу и Литву были призваны упрочить положение завоевателей в регионе и, по всей вероятности, поставить под контроль данные государства. Не исключено, что данная военно-политическая задача была Бурундаем выполнена. По крайней мере, в 1392 г. хан Токтамыш требовал от великого князя Литовского Ягайлы выплат дани: «С подданных нам волостей собрав выходы, вручи идущим послам для доставления в казну» [3, с. 51]; а в 1508 г. польско-литовский король Сигизмунд взимает «поминки» для крымского хана «с обоих своих скарбов наших $з$ Лядского и $з$ Литовского» [1, с. 4]. Кроме того, проходя через княжества Галицко-Волынской Руси, войска Бурундая поставили под полный политический контроль земли князей Даниила и Василько Романовичей и их сыновей.

Таковы известные нам факты биографии полководца Бурундая. К сожалению, они весьма скупы и отрывочны и не дают ответов на массу важных вопросов. К примеру, нам не известно происхождение Бурундая и его положение в составе элиты Монгольской империи. Однако ряд косвенных свидетельств различных источников в комплексе могут, на наш взгляд, осветить некоторые из указанных выше моментов.

В первую очередь необходимо отметить, что транскрипция - Бурундай сохранилась только в русских источниках - в Галицко-Волынской летописи. В восточных источниках встречается несколько подобных имен нойонов и эмиров, жизнь и деятельность которых, как и Бурундая русских летописей, выпадают на период 1230-1260-х гг.

В частности, в китайской династийной истории «Юань ши» осенью 1236 г. отмечается указ Угедей-каана о пожаловании дворов «простого народа из всех округов Срединной равнины различным князьям [из рода Чингизхана] и прочим родственникам и членам орды...» В том числе упоминается надел и «для Буралдая - в округе Синчжоу» [12, с. 172]. Составитель комментариев издания Р.П. Храпачевский склонен отождествить его с Буралдаем или Буралтаем, упомянутом персидским автором Рашид ад-дином, который называет его родственником и приемником Боорчу [12, с. 172].

И действительно, Рашид ад-дин в двух местах своего «Сборника летописей», посвященного истории Чингиз-хана и его потомков, отмечает: «Во время 
Угедей-каана его туманом (Богорчин-нойона [Боорчи] - Ю.С.) ведал его племянник по брату, Буралтай, а во время Менгу-Каана - сын Буралтая, Балчик. В эпоху Кубилай-каана тем же туманом ведал сын Богорчин-нойона, впоследствии, также во время Кубилай-каана, ведал сын Буралтая, Джиргамиш. Этот Буралтай имел много сыновей, и они все были старшими эмирами...» [27, c. 170]. В другом месте описано несколько иначе: «когда в эпоху Угедей-каана он скончался (Богорчин-нойон [Боорчи] - Ю.С.), местом его владел Буралдай. Во время Менгу-каана ведал сын Боорчи-нойона, Ил-Тимур, а в последствии Буралдай, сын Иргатмыша, у последнего было много других сыновей, все они - старшие эмиры. Один из них, Ур-Тимур - эмир стольников, инак (друг) и известное лицо в этом владении (Иране), к его потомкам принадлежат Беклемиш и его сын Учан, ещё Тулак, который за стачку с Сукаем был казнен» [28, c. 267]. Такими образом, Рашид-ад-Дин называет двух Бурулдаев, последовательно владевших должностью главы правого крыла. Если первый был племянником Боорчи-нойона, то второй жил уже после правления Менгу-каана (после 1259 г.), и именно у него было множество сыновей.

Персидский автор отмечает участие Буралдая в западном походе 12351242 гг. и его значительную роль в завоевании Венгрии [29, с. 37].

Кроме того, у Рашид ад-дина сохранились упоминание имени ещё одного эмира, четко созвучного с Бурундаем русских летописей: «В эпоху Чингизхана из племени курлаут-уймакут был старший эмир Эбуген-нойон; его сын Бурунтай-нойон во время Чингиз-хана также был почтенным эмиром; его сын Туртака-нойон состоял при Арик-Бука и постоянно сопровождал его» [27, с. 117]. Причем, ко времени написания «Сборника летописей» (нач. XIV в.) Туртака-нойон был ещё жив и активно действовал при дворе Тимуркаана (1294-1307) [27, с. 117].

Кроме того, в «Сокровенном сказании» встречается упоминание о том, что «к Чингис-хану на урочище Гулелгу пришло <..> известие от МулекеТотаха и Боролдая из племени Икирес» [18, с. 112]. Правда, дальнейшая судьба этого Боролдая неизвестна. Но именно поэтому возможность его участия в западном походе монголов не может быть однозначно отвергнута.

Также персидский историк отмечает в 1260 г. смерть старшего эмира («скончались многие старшие эмиры») Бурунгтай-нойона [30, с. 50]. Данное упоминание, таким образом, может относиться к любому из названных Рашид ад-дином «Бурулдаев/Бурундаев».

Таким образом, однозначной возможности отождествить между собой всех упоминаемых синхронно в источниках различного происхождения Бурундаев/Буралдаев не существует. Можно лишь с определённой уверенностью говорить о смерти Бурундая в 1260 г., так как и со страниц русских летописей его имя исчезает именно тогда.

Надо полагать, что внимание восточных авторов и, в частности, Рашид ад-дина не могло быть привлечено к рядовому, одному из многих эмиров. Вызвать необходимость внести имя в хронику могло родовитое происхождение действующего лица, то есть семейная связь с родом Чингиз-хана, либо какие-либо выдающиеся происшествия и события в жизни подобного человека. Именно потому надо полагать, что участника похода на запад, в том числе и на Русь (который, несомненно, и есть Бурундай русских летописей), необходимо отождествить с Буралтаем, племянником Богорчин-нойона 
(Боорчи). Последний был первым нукером и верным сподвижником Чингизхана, пользовался уважением и покровительством монгольского правителя. Его близкие родственники, к примеру, племянники должны были попасть в поле зрение летописцев.

Кроме того, по данным того же Рашид ад-дина, Буралтай в период правления Угедей-каана командовал туманом Богорчин-нойона (Боорчи) или «местом его владел» $[27$, с. $170 ; 28$, с. 267]. А Богорчин-нойон (Боорчи) сначала «был эмиром личной охраны [казик], потом стал эмиром-темником, а затем ведал [войском] правой руки» [28, с. 267]. В «Сокровенном сказании» упоминается назначение Чингиз-хана, подтверждающее положение Боорчи: «Пусть Боорчу ведает тьмою Правого корпуса, прилегающей к Алтаю» [18, с. 161]. Таким образом, глава правого крыла возглавлял одновременно тумен (и, вероятно, соответствующую тысячу), располагавшуюся на крайней правой (западной) территории страны. Именно на крайнюю западную границу Монгольской империи перемещается в конце $1250-$ х гг. Бурундай, что может быть косвенным свидетельством в пользу отождествления Буралтая - племянника Боорчу - с Бурундаем русских летописей.

Однако сама личность отца Буралтая - брата Боорчу - вызывает массу вопросов. Дело в том, что в «Сокровенном сказании» при встрече около 1177 г. Боорчу и Тэмуджина (будущего Чингиз-хана) отмечается: «Мой отец прозывается Наху-Баяном. Я его единственный сын, зовусь Боорчу» [18, c. 94, 95]. Однако при описании событий 1189 г. автор памятника уже указывает: «Из племени Арулад выделился и пришел к своему брату, Боорчу, младший его брат, Огелен-черби» [18, с. 107]. В то же время, Рашид ад-дин при распределении Чингиз-ханом командующих тысячами упоминает: «...Тукули-Чэрби, который был эмиром-тысяцким левого крыла, был братом Богорчин-нойона» [27, с. 170]. Среди эмиров левого крыла, после тысячи Субэдай-бахадура у персидского автора следует: «Тысяча Доклоку-Чэрби, бывшего из племени арулат, брата Боорчи-нойона. Смысл [слова] Доклоку: тот, кто много раз повторяет слова [заика], а чэрби значит “чистосердечный” и “искренний”» [28, с. 272-273].

Таким образом, после 1177 г. у Боорчу появился младший брат, которому, правда, к 1189 г. могло быть не больше 12 лет. Однако к 1203 г., когда Чингиз-хан ввёл высший воинский чин чербия [18, с. 144; 37, с. 262] (и Огелен, и Тукули (Доклоку) - названы в письменных памятниках чербиями), брату Боорчи могло быть около 20 лет (не более 23-х). Стало быть, племянник одного из ближайших сподвижников Чингиз-хана мог появиться на свет на рубеже XII-XIII столетий (условно - в 1200 г.). Тогда, во время нашествия на Русь ему должно было быть около 37-40 лет, а к моменту смерти, отмеченной Рашид ад-дином в 1260 г. - около 60 лет.

Однако в «Сокровенном сказании» и в «Сборнике летописей» Рашид аддина братом Боорчи названы разные лица - соответственно, Огелен и Тукули (Доклоку). Не исключено, что они оба были близкими родственниками соратника Чингиз-хана. Однако у персидского автора встречается упоминание тысячи (левое крыло) «Окэлэ-Чэрби, бывшего из племени сунит» [28, с. 273]. А в «Сокровенном сказании» отмечается, что в 1189 г. на курултай к Чингизхану прибыли «из племени Манхуд - братья Чжетай и Дохолху-черби». Причем Рашид ад-дин также отмечает тысячу «Джэдай-нойона. Он был из племе- 
ни мангут» [27, с. 121-122, 184-185; 28, с. 268]. Таким образом, именно информация персидского историка вносит сомнения и путаницу в свидетельства о личности брата Боорчу. Поскольку в рассматриваемой части «Сокровенного сказания» повествование ведется от первого лица: «Проехали без сна всю ночь. Рассвело. Осмотрелись и видим, что к нам подошли следующие племена...» [18, с. 107], то есть все основания полагать, что рассказ об избрании Чингиз-хана в 1189 г. записывал свидетель, или, во всяком случае, он был записан со слов свидетелей. Потому предпочтительным является указание монгольского эпического произведения, нежели персидского историка начала XIV в.

Косвенным подтверждением родственных связей Боорчу именно с Огеленом может служить карьерный рост последнего, отмеченный в «Сокровенном сказании». В 1206 г. Чингиз-хан распорядился: «Прежний отряд турхаутов, вступивший в службу вместе с чербием Оголе, пополнить до 1000 и передать под командование чербия Оголе же, из родичей Боорчу...» [18, с. 169]. А затем, при распределении полномочий кишектенов-гвардейцев упомянуто: «... с правой стороны от дворца надлежит располагать... Оголееву... дневную стражу...» [18, с. 174]. Как известно, Боорчу был командующим правого крыла, потому вполне закономерно, что и его брат принадлежал к правосторонней части войсковых подразделений, учреждённых Чингиз-ханом.

Таким образом, из упоминаемых в письменных источниках лиц наиболее предпочтительной фигурой на роль брата Боорчу можно считать Огеленчерби. Соответственно, его же следует признать отцом Бурундая. Последний, по всей вероятности, родился около 1200 г. После смерти Боорчу (после 1229 и до 1241 гг.) Бурундай занял должность командующего правым крылом армии, в ведение которого, по всей видимости, включались и войска Джучиева улуса. В 1236 г. он получил удел в Синчжоу, причем при перечислении распределяемых земель он назван четвертым после Бату (внука Чингиз-хана), Чагатая (сына Чингиз-хана и брата действовавшего на тот момента каана Угедея), Гуюка (сына Угедея) и перед Кульканом (сыном Чингиз-хана), что свидетельствует о его высоком статусе на тот момент среди аристократии Монгольской империи. Надо полагать, что именно в силу своих должностных обязанностей (глава войск правого крыла) он участвовал в западном походе монголо-татар 1236-1241 гг.

\section{СПИСОК ЛИТЕРАТУРЫ}

1. Акты, относящиеся к истории Западной России, собранные и изданные археографическою комиссиею. СПб., 1848. Т. 2. № 6.

2. Астайкин А.А. Летописи о монгольских вторжениях на Русь // Арабески истории, Вып. 3-4: Русский разлив. М., 1996. Т. 1. С. 469-470.

3. Березин И.Н. Ханские ярлыки, I: Ярлык Тохтамыш-хана к Ягайле. Казань, 1850.

4. Галицко-Волынская летопись // Библиотека литературы Древней Руси, Т. 5: XIII в. СПб.: Наука, 2000.

5. Греков Б.Д. Татарское нашествие // Исторический журнал. 1937. № 6. С. 46-63.

6. Греков Б.Д., Якубовский А.Ю. Золотая Орда и ее падение. М.; Л., 1950.

7. Греков И.Б., Шахмагонов Ф.Ф. Мир истории: русские княжества в XIIIXIV вв. М., 1986.

8. Гумилев Л.Н. Древняя Русь и великая степь. М., 1992. 
9. Гумилев Л.Н. От Руси к России. М., 1994.

10. Добролюбский А.О., Руссев Н.Д. Кочевое и оседлое население степей СевероЗападного Причерноморья в X-XIV вв. // Исследования по археологии СевероЗападного Причерноморья. Киев, 1986. С. 177-184.

11. Егоров В.Л. Историческая география Золотой Орды в XIII-XIV вв. М., 1985.

12. Золотая Орда в источниках (Материалы для истории Золотой Орды или улуса Джучи). М., 2009. Т. 3.

13. Иванов А.И. Походы монголов в Россию по официальной китайской истории Юань-ши // Записки разряда военной археологии и археографии Русского военноисторического общества. Пг., 1914. Т. 3.

14. Исхаков Д.М. О клановом составе первоначального удела Шибана // Золотоордынское наследие. Вып. 1: Материалы Международной научной конференции «Политическая и социально-экономическая история Золотой Орды (XIII-XVвв.)». Казань: Идательство “Фэн” АН РТ, 2009. С. 25-26.

15. Карамзин Н.М. История Государства Российского. СПб., 1842. Т. 4.

16. Каргалов В.В. Внешнеполитические факторы развития феодальной Руси. М., 1967.

17. Каргалов В.В. Русь и кочевники. М., 2004.

18. Козин С.А. Сокровенное сказание. М.; Л., 1941.

19. Костомаров Н.И. Русская история в жизнеописаниях её главнейших деятелей. Господство дома св. Владимира. М., 1993.

20. Мустакимов И.А. Владения Шибана и Абу-л-Хайр-хана по данным «Таварих-и гузида-Нусрат-наме» // Национальная история татар: теоретико-методологическое введение. Казань: Институт истории им. Ш. Марджани АН РТ, 2009. С. 222.

21. Мустакимов И.А. Ещё раз к вопросу о предках «Мамая-царя» // Тюркологический сборник. 2007-2008. М., 2009. С. 273-274.

22. Новгородская первая летопись старшего и младшего изводов. М.; Л., 1950. $576 \mathrm{c}$.

23. Пашуто В.T. Героическая борьба русского народа за независимость (ХІІІ век). М., 1956.

24. Пашуто B.T. Монгольский поход в глубь Европы // Татаро-монголы в Азии и Европе. М., 1977.

25. Пашуто В.Т. Очерки по истории Галицко-Волынской Руси. М., 1950.

26. Полное собрание русских летописей. М.: Языки русской культуры, 2000. T. 15.

27. Рашид-ад-Дин. Сборник летописей. М.; Л., 1952. Т. І. Кн. 1.

28. Рашид-ад-Дин. Сборник летописей. М.; Л., 1952. Т. І. Кн. 2.

29. Рашид-ад-Дин. Сборник летописей. М.; Л., 1952. Т. ІІ.

30. Рашид-ад-Дин. Сборник летописей. М.; Л., 1946. Т. ІІІ.

31. Сафаргалиев М.Г. Распад Золотой Орды. Саранск, 1960.

32. Соловьев С.М. История России с древнейших времен. М., 1993. Т. 2.

33. Татищев В.Н. История Российская. М.; Л., 1964. Т. 4.

34. Феннел Дж. Кризис средневековой Руси. 1200-1304 гг. М., 1989.

35. Хрусталёв Д.Г. Русь: от нашествия до «ига» (30-40-е гг. ХІІІ в.). СПб., 2004.

36. Черепнин Л.В. Монголо-татары на Руси // Татаро-монголы в Азии и Европе. М., 1977. С. 187-189.

37. Чингисиана: свод свидетельств современников. М., 2009.

38. Шетэля В.M. Борьба Польского государства с вторжениями татаро-монгольских войск // Славяне и их соседи. Славяне и кочевой мир. М., 1998. С. 149-151.

39. Halperin Ch.J. Omissions of national memory: Russian historiography on the Golden Horde as politics of inclusion and exclusion // Ab imperio. 2004. № 3. P. 131-144.

40. Halperin Ch.J. Russia and the Mongols: Slavs and the Steppe in Medieval and Early Modern Russia. Bucuresti: Editura Academiei Romane, 2007. 
41. Halperin Ch.J. The Tatar yoke: The image of the Mongols in medieval Russia. Bloomington, 2009.

Сведения об авторе: Юрий Васильевич Селезнёв - доктор исторических наук, профессор кафедры истории России Воронежского государственного университета (394068, Московский проспект, 88, Воронеж, Российская Федерация); ORCID: 00000002-8224-445X. E-mail: orda1359@mail.ru

Поступила 28.01.2021 Принята к публикациии 17.05.2021

Опубликована 29.06.2021

\section{REFERENCES}

1. Akty, otnosyashchiesya $k$ istorii Zapadnoy Rossii, sobrannye $i$ izdannye arkheograficheskoyu komissieyu [Acts Relating to the History of Western Russia Collected and Published by the Archaeographic Commission]. St. Petersburg, 1848, vol. 2, no. 6. (In Russian)

2. Astaykin A.A. Letopisi o mongol'skikh vtorzheniyakh na Rus' [Chronicles of the Mongol invasions of Rus']. Arabeski istorii, iss. 3-4: Russkiy razliv [Arabesque of History, Vol. 3-4: Russian Razliv]. Moscow, 1996, vol. 1, pp. 469-470. (In Russian)

3. Berezin I.N. Khanskie yarlyki, I: Yarlyk Tokhtamysh-khana k Yagayle [Khans' Yarliqs, I: Toqtamïsh Khan's Yarliq to Jagiełło]. Kazan, 1850. (In Russian)

4. Galitsko-Volynskaya letopis' [Halych-Volhynian Chronicle]. Biblioteka literatury Drevney Rusi, T. 5: XIII v. [Library of Literature of Ancient Rus', Vol. 5: The thirteenth century]. St. Petersburg: Nauka, 2000. 234 p. (In Russian)

5. Grekov B.D. Tatarskoe nashestvie [The Tatar invasion]. Istoricheskiy zhurnal [Historical Journal]. 1937, no. 6, pp. 46-63. (In Russian)

6. Grekov B.D., Yakubovskiy A.Yu. Zolotaya Orda i ee padenie [The Golden Horde and Its Fall]. Moscow; Leningrad, 1950. (In Russian)

7. Grekov I.B., Shakhmagonov F.F. Mir istorii: russkie knyazhestva v XIII-XIV vv. [The World of History: Rus' Principalities in the thirteenth and fourteenth century]. Moscow, 1986. (In Russian)

8. Gumilev L.N. Drevnyaya Rus' $i$ velikaya step' [Ancient Rus' and the Great Steppe]. Moscow, 1992. (In Russian)

9. Gumilev L.N. Ot Rusi k Rossii [From Rus' to Russia]. Moscow, 1994. (In Russian)

10. Dobrolyubskiy A.O., Russev N.D. Kochevoe i osedloe naselenie stepey SeveroZapadnogo Prichernomor'ya v X-XIV vv. [Nomadic and sedentary population of the steppes of the northwestern Black Sea region from the tenth to fourteenth centuries]. Issledovaniya po arkheologii Severo-Zapadnogo Prichernomor'ya [Research in the Archaeology of the Northwestern Black Sea Region]. Kyiv, 1986, pp. 177-184. (In Russian)

11. Egorov V.L. Istoricheskaya geografiya Zolotoy Ordy v XIII-XIV vv. [Historical Geography of the Golden Horde in the thirteenth and fourteenth century]. Moscow, 1985. (In Russian)

12. Zolotaya Orda $v$ istochnikakh (Materialy dlya istorii Zolotoy Ordy ili ulusa Dzhuchi) [The Golden Horde in Sources (materials for the history of the Golden Horde or the ulus of Jochi)]. Moscow, 2009, vol. 3. (In Russian)

13. Ivanov A.I. Pokhody mongolov v Rossiyu po ofitsial'noy kitayskoy istorii Yuan'shi [Mongol campaigns to Russia according to the official Chinese history Yüan-shih]. Zapiski razryada voennoy arkheologii $i$ arkheografii Russkogo voenno-istoricheskogo 
obshchestva [Notes of the Department of Military Archaeology and Archaeography of the Russian Military Historical Society]. Petrograd, 1914, vol. 3. (In Russian)

14. Iskhakov D.M. O klanovom sostave pervonachal'nogo udela Shibana [About the clan composition of the original appanage of Shiban]. Zolotoordynskoe nasledie, Iss.1: Materialy Mezhdunarodnoy nauchnoy konferentsii "Politicheskaya $i$ sotsial'no-ekonomicheskaya istoriya Zolotoy Ordy (XIII-XV vv.)" [Golden Horde Legacy, Vol. 1: Proceedings of the International Research Conference "Political and Socio-Economic History of the Golden Horde (form the thirteenth to fifteenth century)"]. Kazan: Fen, 2009, pp. 2526. (In Russian)

15. Karamzin N.M. Istoriya Gosudarstva Rossiyskogo [History of the Russian State]. St. Petersburg, 1842, vol. 4. (In Russian)

16. Kargalov V.V. Vneshnepoliticheskie faktory razvitiya feodal'noy Rusi [Foreign Policy Factors in the Development of Feudal Rus']. Moscow, 1967. (In Russian)

17. Kargalov V.V. Rus' $i$ kochevniki [Rus' and the Nomads]. Moscow, 2004, pp. 103202. (In Russian)

18. Kozin S.A. Sokrovennoe skazanie [The Secret History of the Mongols]. Moscow; Leningrad, 1941. (In Russian)

19. Kostomarov N.I. Russkaya istoriya $v$ zhizneopisaniyakh ee glavneyshikh deyateley. Gospodstvo doma sv. Vladimira [Russian History in the Biographies of Its Main Figures. Domination of the House of St. Vladimir]. Moscow, 1993, pp. 154-157. (In Russian)

20. Mustakimov I.A. Vladeniya Shibana i Abu-l-Khayr-khana po dannym "Tavarikh-i guzida-Nusrat-name" [Possessions of Shiban and Abu'l-Khayr Khan according to the "Tawarikh-i Guzida Nusrat-Namah"]. Natsional'naya istoriya tatar: teoretiko-metodologicheskoe vvedenie [National History of the Tatars: Theoretical and Methodological Introduction]. Kazan: Marjani Institute of History of Tatarstan Academy of Sciences, 2009, p. 222. (In Russian)

21. Mustakimov I.A. Eshche raz k voprosu o predkakh "Mamaya-tsarya" [Once again to the question about the ancestors of "Mamai Tsar"]. Tyurkologicheskiy sbornik. 20072008 [Turkological Collection. 2007-2008]. Moscow, 2009, pp. 273-274. (In Russian)

22. Novgorodskaya pervaya letopis' starshego i mladshego izvodov [Novgorod First Chronicle of the Senior and Junior Edition]. Moscow; Leningrad, 1950. 576 p. (In Russian)

23. Pashuto V.T. Geroicheskaya bor'ba russkogo naroda za nezavisimost' (XIII vek) [Heroic Struggle of the Russian People for Independence (thirteenth century)]. Moscow, 1956. 245 p. (In Russian)

24. Pashuto V.T. Mongol'skiy pokhod v glub' Evropy [Mongol campaign deep into Europe]. Tataro-mongoly v Azii i Evrope [The Tatar-Mongols in Asia and Europe]. Moscow, 1977. (In Russian)

25. Pashuto V.T. Ocherki po istorii Galitsko-Volynskoy Rusi [Essays on the History of Halych-Volhynian Rus']. Moscow, 1950. 220 p. (In Russian)

26. Polnoe sobranie russkikh letopisey [Complete Collection of Russian Chronicles]. Moscow: Languages of Russian culture, 2000, vol. 15. (In Russian).

27. Rashid al-Din. Sbornik letopisey [Compendium of Chronicles]. Moscow; Leningrad, 1952, vol. 1, part 1. (In Russian)

28. Rashid al-Din. Sbornik letopisey [Compendium of Chronicles]. Moscow; Leningrad, 1952, vol. 2, part 2. (In Russian)

29. Rashid al-Din. Sbornik letopisey [Compendium of Chronicles]. Moscow; Leningrad, 1952, vol. 2. (In Russian)

30. Rashid al-Din. Sbornik letopisey [Compendium of Chronicles]. Moscow; Leningrad, 1946, vol. 3. (In Russian)

31. Safargaliev M.G. Raspad Zolotoy Ordy [Dissolution of the Golden Horde]. Saransk, 1960. (In Russian)

32. Solov'ev S.M. Istoriya Rossii s drevneyshikh vremen [History of Russia from the Most Ancient Times]. Moscow, 1993, vol. 2. (In Russian) 
33. Tatishchev V.N. Istoriya Rossiyskaya [Russian History]. Moscow; Leningrad, 1964, vol. 4. (In Russian)

34. Fennell J. Krizis srednevekovoy Rusi. 1200-1304 gg. [The Crisis of Medieval Russia 1200-1304]. Moscow, 1989. (In Russian)

35. Khrustalev D.G. Rus': ot nashestviya do "iga” (30-40-e gg. XIII v.) [Rus': From the Invasion to the "Yoke" (1230-1240s)]. St. Petersburg, 2004. (In Russian)

36. Cherepnin L.V. Mongolo-tatary na Rusi [The Mongol-Tatars in Rus']. Tataromongoly v Azii i Evrope [The Tatar-Mongols in Asia in Europe]. Moscow, 1977, pp. 187189. (In Russian)

37. Chingisiana: svod svidetel'stv sovremennikov [Chinggisiana: A Collection of Contemporary Testimonies]. Moscow, 2009. (In Russian)

38. Shetelya V.M. Bor'ba Pol'skogo gosudarstva s vtorzheniyami tataro-mongol'skikh voysk [The fight of the Polish State against the invasions of the Tatar-Mongol troops]. Slavyane $i$ ikh sosedi. Slavyane $i$ kochevoy mir [Slavs and Their Neighbors. Slavs and the Nomadic World]. Moscow, 1998, pp. 149-151. (In Russian)

39. Halperin Ch.J. Omissions of national memory: Russian historiography on the Golden Horde as politics of inclusion and exclusion. Ab imperio. 2004, no. 3, pp. 131-144.

40. Halperin Ch.J. Russia and the Mongols: Slavs and the Steppe in Medieval and Early Modern Russia. Bucuresti: Editura Academiei Romane, 2007.

41. Halperin Ch.J. The Tatar Yoke: The Image of the Mongols in Medieval Russia. Bloomington, 2009.

About the author: Yury V. Seleznev - Dr. Sci. (History), Associate Professor, Department of History of Russia of the Voronezh State University (88, Moskovsky Avenue, Voronezh 394068, Russian Federation); ORCID: 0000-0002-8224-445X. E-mail: orda1359@mail.ru 


\title{
THE LOSS AND REACQUISITION OF CAFFA: THE STATUS OF THE GENOESE ENTREPÔT WITHIN THE BORDERS OF THE GOLDEN HORDE
}

\author{
Roman Hautala ${ }^{1,2}$ \\ ${ }^{1}$ Marjani Institute of History of Tatarstan Academy of Sciences \\ Kazan, Russian Federation \\ ${ }^{2}$ University of Oulu \\ Oulu, Finland \\ romanhautala@gmail.com
}

\begin{abstract}
Research objectives: To analyze both the circumstances of the armed conflict of Genoese Caffa with the troops of the Golden Horde ruler, Toqta Khan, in 13071308, which ended with the temporary expulsion of Italian merchants from the Jöchid territory, and their return to Caffa under Toqta's nephew and successor, Özbeg Khan.

Research materials: The information on the conflict between the Genoese and Toqta Khan is contained in an anonymous continuation of the chronicle of the Genoese Archbishop, Jacopo da Varagine, dating to the middle of the fourteenth century; in the chronicles of the Mamluk authors, Baybars al-Mansuri and al-Nuwayri; and in a local Greek source, namely the Sugdeian Synaxarion. In turn, sources that provide information about the circumstances and conditions of the return of the Genoese are much more diverse. Of course, the most important details are contained in the official documents of Genoa and Caffa. Valuable details are also contained in the missionary sources of the Franciscans preaching the gospel within the Golden Horde. For its part, the Franciscan information is useful to compare with that found in Rus'ian sources regarding the relations of Catholic and Orthodox prelates with the Khan of the Golden Horde.

Research novelty: This study highlights that the use of Franciscan sources appears to be extremely useful to complement the analysis of the relationship of the Genoese entrepôt of Caffa with the local authorities.

Research results: An analysis of the conflict between the Genoese and the local authorities, along with the conditions of their return negotiated with the new Khan of the Golden Horde, reveals the obvious fact that Caffa, having undoubtedly grown in the Golden Horde period due to the activities of the Genoese immigrants, had to recognize its submission to the Jöchid rulers from its very foundation. The Genoese administration likewise recognized this dependence during the restoration of Caffa in the first years of Özbeg Khan's reign.
\end{abstract}

Keywords: history of the Golden Horde, Italian trade in the Mongol Empire, Genoese entrepôt of Caffa, Catholic missionary activity in the east, Latin and Muslim sources

For citation: Hautala R. The Loss and Reacquisition of Caffa: The Status of the Genoese Entrepôt within the Borders of the Golden Horde. Zolotoordynskoe obozrenie=Golden Horde Review. 2021, vol. 9, no. 2, pp. 247-263. DOI: 10.22378/2313-6197.2021-9-2.247263 
According to the convincing arguments of Michel Balard, the first Genoese immigrants were able to settle in Caffa between 1270 and 1275, and by about 1285 Caffa grew to the scale of a large Genoese entrepôt, which was destined to play a leading role in the economic life of the Ligurian capital over the next two centuries [3, p. 114-118]. However, the question of the origin of the Genoese entrepôt and its initial status within the borders of the Golden Horde remains unclear due to the absence of any documents (or their traces) that would reflect the conditions for a possible agreement between the Genoese and Möngkä Temür Khan or at least a local government of Solkhat. We can only guess whether Caffa was bought by the Genoese or received as a gift in exchange for a guarantee of the payment of any taxes. The status of the Genoese who regularly visited Caffa or decided to settle in a new Genoese entrepôt, remains unclear, too. Obviously, the Genoese did not lose touch with the metropolis and continued to enjoy the privileges granted to them by the citizenship of the Ligurian capital. However, contemporary sources do not contain sufficient information regarding the degree of simultaneous and parallel subordination of the Genoese inhabitants of Caffa to the power of the Jöchid khans and leave the impression that the Caffa's comune asserted its independent status within the Golden Horde and recognized its dependence solely on the Ligurian metropolis.

The fact that this impression is misleading is confirmed by the analysis of the first armed conflict between the Genoese and the Jöchid authorities, which forced Western merchants to agree to new, less favorable conditions put forward by the Golden Horde Khan. As with the initial agreement, we do not have the text of a new agreement between Genoa and the Khan. Nevertheless, the circumstances of the return of the Genoese to Crimea and the restoration of Caffa are reflected in written sources in a larger volume and suggest the conditions of the new agreement with greater credibility. Revealing the details of the new treaty remains largely hypothetical. Nevertheless, the sources given below reflecting the consequences of this treaty, leave no doubt that the comune of Caffa recognized its subordinate status within the borders of the ulus of Jöchi and probably had recognized it from the very beginning of its existence.

\section{The Expulsion of the Genoese from the Golden Horde}

According to an anonymous continuation of the chronicle of the Genoese Archbishop, Jacopo da Varagine, of the middle of the fourteenth century, on 4 October 1307 Toqta "ordered to capture all the Genoese in his entire empire", and in November of that year he sent his son Il-Basar with troops to Crimea to besiege Caffa. The Genoese held the city's defenses with the local Greeks for eight months, but on 20 May 1308 they were forced to leave and burn the city:

"In the year of Lord 1307, on the feast of St Francis, Toqta, the Emperor of Tartars in the domain of Gazaria, because of the arrogance that the Genoese repeatedly expressed in his Empire, commanded to capture all the Genoese in his entire Empire and seize their property. And this was done so that the merchants who were in Sarai were arrested and robbed, but later, according to the instructions of the Emperor, some of them were taken to Solkhat, and several of them reached Caffa. The rest remained there imprisoned, and later almost all of them died of cold, sword and disease. In the same year, the aforementioned Toqta sent for the destruc- 
tion of Caffa his son Il-Basar ${ }^{1}$, who arrived in Gazaria the same year in the month of November and gathered there his army consisted of one hundred thousand horsemen and foot soldiers and came to Caffa. And there were 300 Genoese and 300 Greeks, who, relying on the help of God, courageously defended themselves and their households against the mentioned enemies of God. And after the mentioned Tartars brutally hit the mentioned city of Caffa with many battles and fires for almost eight months, finally the Genoese who were there saw that due to lack of strength they could not keep the city. They gathered a general council, on which it was decided to leave the city climbing aboard. So on 20 May 1308, Caffa was abandoned and completely burnt by the hands of the mentioned Genoese" 2 .

Obviously, the anonymous Genoese author of the report of this conflict could not find an explanation for these repressions or did not want to reveal their true reason, claiming that Toqta's anger was caused by "the arrogance that the Genoese repeatedly expressed in his Empire"3. He did not explain, therefore, how Toqta Khan managed to endure the similar behavior of Italian merchants all the previous sixteen years of his reign. Al-Nuwayri, in turn, based on the account of Baybars alMansuri, but supplementing it with some details, dated the arrival of information on these events to Egypt back to 707 AH (3 July 1307 - 20 June 1308) and explained that the reason for the repressions was Toqta's desire to take revenge on the "Genoese Franks in Crimea, Caffa and in the Northern possessions for the (various) cases that he was informed about them, including for the capture of Tatars' children by them and their sale to Muslim countries" [46, p. 120 (Baybars alMansuri), 162 (al-Nuwayri)]. However, the latter explanation was hardly true, since Toqta had not previously objected to the trade of Qipchaq slaves, as neither his predecessors nor the successors did. Rather, it was an excuse that Toqta used to justify the repression [3, p. 151].

\footnotetext{
${ }^{1}$ According to al-Nuwayri, Il-Basar (Ir-Bysa[r]) "performed the functions of commander of the troops under his father", and according to several other Mamluk chroniclers, he died in $709 \mathrm{AH}$, that is, between 11 June 1309 and 30 May 1310 [46, p. 123 (Baybars al-Mansuri), 162 (al-Nuwayri), 384 (Ibn Khaldun), 513 (al-Ayni)]. Apparently, Vladimir Tizengauzen incorrectly read the date of his death $(707 \mathrm{AH})$ in the text of al-Nuwayri $[9$, p. 116, note 110].

2 "Anno Domini .MCCCVII., in festo beati Francisci, Toctai imperator Tartarorum in dominio Gazarie, propter multas superbias quas Ianuenses fecerant in suo imperio, precepit quod omnes Ianuenses essent capti per totum suum imperium in here et persona. quod et factum fuit, ita quod mercatores, qui erant in Saray, capti fuerunt et depredati; sed postea ex precepto dicti imperatoris persone eorum usque in Sulcati ducti fuerunt et aliqui in Caffa venerunt, reliqui remanserunt ibi incarcerati, qui postea quasi toti frigori, gladio et desasio perierunt. dicto autem millesimo dictus Thoctai missit ad destructionem Caffe Elbazar filium suum qui aplicuit in Gazaria dicto millesimo de mense novembris et ibi congregavit exercitum suum inter equites et pedites centum milia et venit in Caffa. erant Ianuenses .CCC. et Greci .CCC. et sperantes in adiutorio Dei ad se deffendendum et familias eorum et contra dictos inimicos Dei se viriliter posuerunt et cum multis preliis et incendiis dictam terram Caffa dicti Tartari fere per menses .VIII. duriter aflixissent. ultimo, videntes Ianuenses ibi existentes quod propter deficientiam quam non habebant terram tenere non potuebant, fecerunt conscilium generale in quo deliberatum fuit derelinquere terram et ascendere in lignis. ita quod die .XX. maij .MCCCVIII. derelicta fuit Caffa et tota igne combusta manibus dictorum Ianuensium" [27, p. 479-480]. According to the Sugdeian Synaxarion, Caffa was plundered by the Tatars the day after its capture, 21 May 1308 [31, no. 125, p. 129; 2, no. 120, p. 613].

${ }^{3}$ Nicola Di Cosmo showed confidence in this statement of the Genoese anonymous [10, p. 413].
} 
For his part, Bertold Spuler believed that the reason for the repressions, in addition to the slave trade, was the cooperation of the Genoese with the Ilkhanate. This explanation, however, was his dubious conjecture, since he did not provide references to sources that would confirm it [44, p. 84]. Equally speculative is the hypothesis of Viktor Myts, according to which Toqta, "having settled state affairs" by destroying Nogai and his supporters, decided to take revenge on the Genoese for their alleged alliance with Nogai, also weakly justified by Myts. Myts did not explain why Toqta, in this case, hatched plans for revenge on the Genoese for so long and implemented them only seven years after the death of Nogai. In the Myts's reference, al-Maqrizi does not really mean the stabilization of the internal situation in the Golden Horde by the term "settling affairs", but the reconciliation of the Mamluk sultan al-Malik al-Nasir with the Ilkhan Öljeitü [46, p. 436; 30, p. 75].

The Virgil Ciocîltan's hypothesis, recently introduced by Marie Favereau as well, seems more significant: Toqta could interrupt the slave trade and, accordingly, expel Italian merchants from his possessions in order to punish the Egyptian sultan for his unwillingness to conduct joint military operations against the Ilkhanate and deprive his army of replenishment with new Qipchaq slaves [7, p. 170-171; 12, p. 343]. However, it is difficult to find direct confirmation of this hypothesis in the sources. Therefore, perhaps a more plausible reason will be presented below: Toqta could enact reprisals against Italian merchants in connection with their sharp refusal to accept the intention of the Khan to raise the main tax on their trading activities. In the end, Western merchants had to accept the new conditions. However, they did this already under the new Khan, who allowed the Genoese to return to Caffa on the conditions that they tried to initially reject.

\section{The Return of the Genoese to Caffa}

The Genoese, obviously, returned to Caffa at the first opportunity and, apparently, shortly after the departure of the Tatar troops. This is confirmed by one notarial act from the State Archives of Genoa: in February 1310, Galverio Bibia di Sant'Ambrogio contracted in Caffa his 17-year-old slave woman named Caterina of Magyar origin ("de proienie maiariorum") to Nicolosa, the widow of a notary Giovanni Rosso [45, p. 453]. In addition, the letter of the Dominican General Master, Bérenger de Landore, addressed to Franco of Perugia, the Vicar of the Caffa's Dominicans, implies the presence of the Friars Preachers there already in 1312 [28, p. 313,318$]^{4}$.

In turn, an anonymous continuator of the chronicle of Jacopo da Varagine indicates that, "thanks to the grace provided to them by Özbeg, the Emperor of Tartars", the official representatives of the comune of Genoa, namely, Antonio Grillo and Niccolo di Pagano, were able to rebuild Caffa by $1316^{5}$. This latter date, obviously, did not mean the moment of granting permission by Özbeg, but visible ef-

${ }^{4}$ The Italian Dominican Franco of Perugia led his fellow friars of the Order in the Golden Horde and Ilkhanate since about 1304 [24, p. 2; 23, p. 18], until Pope John XXII elevated him to the dignity of the first Latin Archbishop of Sultania in the Ilkhanate by the bull Redemptor noster of 1 April 1318 [17, p. 201].

5 “Anno Domini .MCCCXVI. redifficata fuit civitas Caffe per dominum Antonium Grillum et dominum Nicolaum de Pagana sindicos communis Ianue per gratiam sibi concessam per Usbech imperatorem Tartarorum" [27, p. 481]. 
fects of Caffa's original restoration orders ${ }^{6}$. Subsequently, the restoration of Caffa was subordinated to the leadership of a special office of the comune of Genoa, called the "Eight Wise Men [appointed by the comune of Genoa] over the affairs of navigation and the Black Sea" (Octo sapientes [constituti per comune Ianue] super factis navigandi et Maris Maioris), later called the "Office of Gazaria" (officium Gazarie) and established in 1313 by a council of 24 wise men of Genoa [see especially 43, col. 406-409]. This office took over all the functions of the former "trade managers" (tractatores mercantiae) established in Genoa in the middle of thirteenth century [33, p. 424, 439, note 3]. However, unlike the latter, it received complete independence in addressing the general and particular issues of navigation of the Genoese both in the Black and Mediterranean Seas, and beyond Gibraltar.

Nevertheless, initially this office was created to address extremely topical issues of the return of the Genoese to the Crimea and the joint efforts of the rulers of Solkhat, Sinop and Trebizond to prevent the Genoese from settling in Caffa again. One of the main reasons for creating the Office of Gazaria was the need to resolve the consequences of the recent attack on Caffa, in May 1313, by the combined fleet of the Trapezuntine Emperor, Alexios II, and Gazi Çelebi, the Turkish ruler of Sinop, as well as the synchronous attack of troops from Solkhat [8, p. 519, 528, 530. See also 27 , p. 480-481; 41, p. 502; 20, p. 282; 3, p. 202]. The damage suffered by the Genoese of Caffa and other Crimean ports during this attack was estimated at 250,000 Komnenoi's aspers (asperi comninati) during negotiations in the town of Arzeron next to Trebizond next year, which culminated in the signing of the Genoese-Trapezuntine treaty on 26 October 1314. Under the same agreement, Alexios II undertook to compensate for the damage caused by local Greeks to the Genoese Giovanni Fantinanti and Giovanni di Chiavari during the attack on their ships in the port of Trebizond, probably in parallel with the Emperor's Crimean expedition [8, p. 514, 519-520, 528. See also 20, p. 282-284; 4, p. 283-284].

The acquiescence of the Trapezuntine Emperor was the result of specific measures taken in this regard by the Genoese Office of Gazaria. Immediately after taking office on 1 May 1314, the eight "wise men" of the Office set about equipping a flotilla consisting of five galleys led by the Admiral, Accellino Grillo, which, in addition to transporting the ambassadors of the Genoa to the Trapezuntine Emperor, was sent at the end of May or early June of that year east to "protect the Black Sea"7. After arriving in Trebizond at the end of August 1314, the flotilla launched military operations in the uncertain waters of the Black Sea until the conclusion of the Genoese-Trapezuntine agreement, mentioned above, on 26 October of that year [1, p. 54-58].

By the time this agreement was signed, the Genoese had already settled firmly in Caffa, and in 1314 they were able to successfully repulse the next joint attack by the Gazi Çelebi's fleet and Solkhat's troops. This fact was eloquently described by the continuator of the Jacopo da Varagine's chronicle: "and the following year the mentioned Çelebi came to the mentioned place [of Caffa] and found there three little ships and one cocha of Giacomo di Carlo, and, having nine galleys and the

\footnotetext{
${ }^{6}$ See the mention of these original decrees in [43, col. 407].

7 "Ad custodiam maris Maioris" [1, p. 77 (act of the notary Francesco da Silvia, rogated in Samsun on 22 December 1314, with reference to the equipping of the flotilla). See also ibidem,
} no. $2-11$, p. $76-81]$. 
help of Solkhat, he could not capture anything as a result of military operations, but took great damage there and came back home with shame, sorrow and damage" 8 .

\section{The Yarliq of 1314}

In the end, Özbeg Khan's patronage was supposed to put an end to the attacks on Caffa. Özbeg provided this protection after concluding an agreement with representatives of the comune of Genoa, as reported by the continuator of the Jacopo da Varagine's chronicle in the fragment mentioned above. Nevertheless, it can be assumed with a certain degree of certainty that this agreement was concluded in 1314, since any attacks on Caffa ended after that year. The yarliq, apparently granted to the Franciscans of Caffa at the same time as the conclusion of this agreement, is an additional argument in favor of this year. The text of this yarliq is preserved only in the Latin translation, at the end of which the exact date of this document is indicated - 20 March 1314:

"By the power of the eternal God and with the approval of [his] great majesty, we, Özbeg, convey these our words: The Latin priests possessing this privilege, who call themselves the minor brothers according to their habit, so that they, namely, move with a serene soul, praying to God and blessing, the privilege granted by Culuk $^{9}$, our progenitor, as well as his successor, our elder brother ${ }^{10}$, the Emperor, we also now give in accordance with the same content, that is, the privilege that, praying to their God, the slaves of Christ, the mentioned Latin priests, go around, teaching Christian law to many. Let absolutely no messenger heading for the census of the army take [anyone] from them to the army under this pretext and take the means of transportation or anything else that would harm them. Let the officials of taxes and tributes not receive neither demand tributes nor census from them neither concern any of their property. Let no one inflict violence or oppression on them, fracturing their church ${ }^{11}$ or destroying their houses or places of residence; but by constructing a church or hanging bells, let them govern the people of Christian law and come out to us to report on the reasons for arriving from far or near and to make us a written report. How, in turn, will we favor them in graces, we shall know $^{12}$. This privilege [is given] in the year of the leopard, in the third month, on the fourth day of the month, near the saffron reed ${ }^{13,}, 14$.

8 "Et anno sequenti venit dictus Zalabi in dicto loco et invenit ibi tria ligna parva et unam cocha Iacobi de Karlo et ipse habens galeas .VIIII. et adiucatorium Solcati preliando nil capere potuit. sed magnum dampnum ibi habuit et cum verecundia, tristitia et dampno ad propria est reversus" [27, p. 481. See also 20, p. 283].

${ }^{9}$ The nickname of Özbeg's grandfather, Möngkä Temür Khan, also known from later sources of the fifteenth and sixteenth centuries [47, p. 205 ("Shajarat al-atrak"); 22, p. 40 (Khwand-Amir); 32, p. 39 (Ötemish Hajji)].

${ }^{10}$ More precisely, the uncle and predecessor of Özbeg, Toqta Khan [34, p. 60].

${ }^{11}$ The Church of St Agnes, according to the bull Ad universalis ecclesiae of Pope John XXII of 26 February 1322 [14, p. 143].

${ }^{12}$ Apparently, meaning by this phrase that the contents of this privilege will become known to all relevant officials. Cfr. with the Rus'ian translation of the Möngkä Temür Khan's yarliq in [6, p. 467].

${ }_{13}^{13}$ Obviously, Sary Kamysh, somewhere in the Lower Volga region.

14 "In virtute eterni dei et magne maiestatis suffragio, Nos Vsbek mandamus hec verba nostra: Istud priuilegium tenentes sacerdotes latini qui suo more se fratres minores appellant, vt videlicet animo tranquillo consistentes, deum rogando, benedictionem faciendo incedant, 
The privileges contained in this yarliq, with the exemption of Franciscans from paying all taxes and military service, are clear evidence of the practice of religious tolerance by the Muslim Özbeg Khan. His confessional tolerance is also confirmed by the permission to build the Franciscan cathedral church in Caffa and even the permission to ring the bells on it - this right remained valid even after the next year Özbeg Khan banned the ringing of Christian bells in other cities of his domain ${ }^{15}$. Khan's separate permission to "go around, teaching Christian law to many" implied freedom of movement along the Golden Horde and was of paramount importance to Western missionaries. So, in 1320, the Hungarian Franciscan Johanca specified in his letter to the Franciscan General Minister, Michele da Cesena, that he and other friars of his Order were able to reach the modern territory of Bashkiria about six years before writing this letter, that is, immediately after the Özbeg's yarliq was granted [29, p. 67].

The recognition of the Franciscans' right to "govern the people of Christian law" seems particularly interesting in this context. Obviously, this expression implied the subordination of the friars and secular members of their Order to the head of the Franciscans, although the leader of the Franciscans and the direct recipient of the yarliq was not named by name in this document. Theoretically, he could be the "Vicar of Gazaria", that is, the former head of the Franciscans in the Golden Horde, mentioned for the first time by the Franciscan Giovanni da Montecorvino in his letter of 13 February 1306 [48, p. 351-352]. However, this nameless vicar was supposed to leave the ulus of Jöchi two years later, along with all the Franciscans as well as Western merchants, during the repressions of Toqta, mentioned above; and his belated return to the Golden Horde is testified only by the bull Nuper ad nostri of Pope John XXII of 22 November 1321 [5, p. 212]. Therefore, it is much more likely that another Franciscan, well known from contemporary sources, was the actual recipient of the yarliq - Jerome of Catalonia, whom Pope Clement V elevated to the rank of Latin Bishop by the bull Rex regum of 19 February 1311 [5, p. 74] and who appeared in Caffa sometime after that, was the actual head of the Franciscans of the Golden Horde, starting from 1312 onwards. Subsequently, on 26 February 1322, Pope John XXII confirmed the fact that Jerome was previously appointed the Bishop "in the lands of Tartars" in his bull Ad universalis ecclesiae and approved Friar Jerome at the head of the Latin diocese of Caffa with canonical jurisdiction, which extended to the entire western and central territory of the ulus of Jöchi ${ }^{16}$. The Genoese documen-

priuilegium quod dederat Culuk progenitor noster et successor eius, frater noster senior, inperator, nos eciam nunc dedimus secundum eundem tenorem, priuilegium scilicet quod deum suum orando xristi servi, dicti sacerdotes latini, legem xristianam multis dicendo ambulent. Nullus omnino nuncius ad recendendum exercitum vadens, ab illis nomine exercitus abstrahat, nec voituram aut aliud eis dampnificum ab illis accipiat; vectigalium vel tributorum officiales nec tributum nec censum ab eis accipiant nec exigant, nec aliquid de rebus ipsorum contingant. Nemo eis violenciam inferat aut oppressionem, ecclesiam frangendo vel domos aut loca destruendo eorum; set faciendo ecclesiam aut campanas xristiane legis homines regant, de longe vel de prope veniencium causas nobis dicendo, nobisque recordacionem faciendo incedant; qualiter autem eis fauebimus in graciis, nos sciemus: hoc priuilegium anno pardy mense $3^{\circ}, 4^{\text {ta }}$ die mensis apud croceam arundinem" [29, p. 65].

${ }^{15}$ Pope John XXII reprimanded Özbeg for imposing this prohibition in his bull addressed to the Khan on 28 March 1318 [5, p. 148]. Ibn Battuta, for his part, witnessed the use of bells by Christians of Caffa in 1334 [16, p. 470-471].

16 “A villa de Varna in Bulgaria usque Saray" [14, p. 142-143]. 
tation, in turn, also confirms the fact that Friar Jerome headed the Caffa's Franciscans by 1316 and built the church of St Agnes in its citadel [43, col. 407], which was destined to become the center of the new Latin diocese ${ }^{17}$.

Thus, the 1314 yarliq was received by the Catholic prelate, who later headed the first Latin diocese on the territory of the Golden Horde taking advantage of the recognition of his legal autonomy by Özbeg Khan. Apparently, the year before, Özbeg granted similar privileges and recognition of legal autonomy to the Kyiv Metropolitan, Petr (with a residence in Vladimir), although the yarliq that the Khan endowed with the Orthodox Metropolitan in 1313, did not preserve in the original, but only in a forged Rus'ian translation made in the Metropolitan Chancellery of Moscow in the $1540 \mathrm{~s}^{18}$. The fact that this yarliq was falsified is confirmed not only by its extremely long content, noticeably different from all the known yarliqs of the Mongol Khans, but also by its erroneous dating: at the end of the translation, the yarliq erroneously dates back to the "year of the hare", which corresponded to 1315, and not 1313 of the Mongolian calendar. It is obvious that the authors of the fake not only had a poor understanding of the dates of the Mongolian calendar, but also did not have the text of the 1313 yarliq on their hands. Therefore, they literally borrowed the dating of the Möngkä Temür Khan's yarliq of 1267 or $1279^{19}$ and used the contents of this yarliq as a model for their significantly expanded falsification [6, p. 464].

Despite this falsification, the Metropolitan Petr really should have received a yarliq from Özbeg as a result of his visit to the Khan's headquarters, as a number of Rus'ian chronicles testify [36, p. 87-88; 40, p. $102 ; 39$, p. $160 ; 37$, p. 97; 38, p. $107 ; 35$, p. 178]. The same chronicles clearly indicate the fact that the Kyiv Metropolitan arrived at Özbeg's headquarters, accompanied by the Great Vladimir Prince, Mikhail Iaroslavovich, who also went to the new Khan to assert his own power in northwestern and northeastern Rus'.

Of course, this analogy cannot exhaustively prove the assumption that a year later the Franciscans went to Özbeg and received a yarliq in 1314 in parallel with the visit of the Genoese representatives to the Khan. Nevertheless, it should be noted here that during negotiations with the Mongol rulers, Italian merchants sought to defend not only their pragmatic interests, but also spiritual requests. Along with obtaining permission to establish their own trading quarters, western merchants received permission to build Catholic churches, and, apparently, Latin missionaries took part in their negotiations with the Mongol rulers. In particular, the Ilkhan Abu Said's yarliq of the end of 1320 (preserved in the Italian translation), which provided the Venetians with freedom of movement throughout all the cities of his domain and determined the terms of their trading activities and corresponding taxation, contained a separate paragraph securing the right of the "Latin Friars" to establish churches in any cities and villages of the Ilkhanate ${ }^{20}$. This paragraph immediately followed the paragraph that allowed Western merchants to es-

${ }^{17}$ The name of the cathedral church is mentioned in the above bull Ad universalis ecclesiae: "ut ecclesia sanctae Agnetis dicti loci Caphen. ex tunc haberetur et existeret perpetuis futuris temporibus cathedralis" [14, p. 143].

${ }^{18}$ See the forged yarliq's translation in [18, p. 112-118].

${ }^{19}$ See the Rus'ian translation of this yarliq in [6, p. 467-468].

20 "Item, se li nostri Frari Latini volesse far in alguna citade o logo del so imperio logo per soa oratio, che li lo possa far; e che alguna persona no li possa dir alguna cosa" [26, p. 99. See also 42 , p. 94]. 
tablish their own caravanserais in the same cities. Obviously, this paragraph met the requirement of the Government of the Venetian Republic, put forward in parallel with the request for the Ilkhan's protection of the merchants during their stay in his possessions. At the same time, this paragraph testified to Ilkhan's consent to comply with this requirement.

This requirement, approved by the Ilkhan Abu Said, reflected the desire of the Venetians to attend their churches in the territories of the Mongol rulers and to participate in masses held by Catholic priests in these churches; and the ubiquitous construction of Catholic churches in all the cities of the Mongol Empire, which were visited by Western merchants, was made possible thanks to the financial support and intercession provided by European merchants to the friars of the Franciscan and Dominican Orders, as the German Carmelite Johann of Hildesheim eloquently emphasized in his treatise On the Deeds and Acts of the Three Holy Kings ("De gestis et factis trium reum beatorum", written between 1364 and 1375): "For merchants from Lombardy and other rich lands, staying in those parts and often arriving there, take with them these Orders to those places and establish cloisters for them with the support of other merchants and faithful, generously supplying them with everything they need according to which of these Orders each of them prefers" 21 .

So, in 1299, the head of the Dominicans in the East, Franco of Perugia, founded a convent of the Friars Preachers in Caffa ${ }^{22}$ thanks to the financial support of local Genoese merchants, according to his obituary from the Chronicle of the Friars of St Dominic of Perugia (Cronica fratrum Sancti Dominici de Perusio) of an anonymous Dominican: "By the will of God, he arrived in Caffa, in the city that belongs to the Empire of the Tartars, and got there a place given to him by the Genoese. He also built a beautiful church there, to the great reverence of all Christian people",23. In turn, 19 years earlier (27 August 1280), Marco Polo Senior (senior uncle of the famous Marco Polo Junior) bequeathed the house that he owned in Soldaia to the local Franciscans, retaining the right of residence in this house for his son, Niccolo, and daughter, Marota: "Also, I bequeath my house, which I have in Soldaia, to the Minor Friars of the same city, keeping the right of residence for the above mentioned son of mine and my daughter, Marota, while they are alive" ${ }^{\text {"24 }}$.

Also, the letter of the Dominican General Master, Bérenger de Landore, addressed to Franco of Perugia on 20 October 1312, reflected the apparent dependence of the Caffa's Dominicans on Western merchants, although it also showed increased concern of the head of the Friars Preachers regarding the participation of the Dominicans in the east in their trading operations: "For indeed, I recently

21 "Nam mercatores de lombardia et alijs terris ditissimi qui in illis partibus degunt et frequenter perueniunt trahunt hos ordines ad illas partes et eis cum auxilio aliorum mercatorum et fidelium claustra fundant et omnia necessaria largiter eis ministrant secundum quod quiuis aliquis ordinem diligit" [the fifteenth century Codex at the Ambrosian Library in Milan, C 70 inf., fol. $475^{\mathrm{v}}$ ].

${ }^{22}$ Friar Franco went to Crimea after receiving the Boniface VIII's bull Immaculata lex Domini of 10 April 1299 and the corresponding powers of the Papal legate [13, p. 209].

23 "Disponente autem Deo, venit in Chaffam terram que ad imperium pertinet Tartarorum, ibidem locum recipiens a Ianuensibus sibi datum. Ecclesiam quoque edificavit pulcram cum magna devotione totius populi" [23, p. 67].

24 "Jtem domum meam quam habeo jn soldathya dimitto fratribus minoribus eiusdem loci, salua habitatione suprascriptorum filij \& filie mee marothe quamdiu uixerint" [25, p. 524]. 
learned from the message of some, not without great heartache, that some of the mentioned Pilgrim Friars, who voluntarily chose extreme poverty together with the poor and mendicant Christ, are more zealous in accumulating money than in eradicating vices. The most harmful thing is that they keep the mentioned money, undeserved alms, in the hands of merchants, so that the owner of this money does not remain unknown, and manage the money without the permission of the prelates, in contradiction with the statutes of the Order"25. Also, the Latin Bishop of Samarkand, Dominican Tommaso Mancasole da Piacenza, did not escape the temptation of enrichment and, finding himself in Tana, on the way to his diocesan chair (in the summer of 1330), he invested 50 liras in a commenda, that is, a trade agreement concluded with a merchant from Piacenza named Roberto di Ripalta, according to one notarial act from the archive of the hospital of Piacenza ${ }^{26}$. This document is an interesting testament to the flagrant violation of the Dominican Order's prescriptions by its prelate, but at the same time this act once again points out the cooperation between Latin missionaries and Western merchants.

\section{Terms of the Agreement of the Genoese with Özbeg Khan}

All these observations serve the purpose of demonstrating the validity of the assumption that the Franciscans of Caffa received the 1314 yarliq from Özbeg in parallel with the negotiations of representatives of Genoa with the Golden Horde Khan. However, unlike the Franciscans, who received full exemption from taxes from Özbeg, the subject of negotiations between the Genoese and the Khan was to be the amount of comercium or the main tax on the activities of Western merchants in the Golden Horde. The Özbeg's yarliq granted to the Venetians of Tana on 17 September 1332, determined this tax in the amount of three percent of the value of goods sold or consumed [11, p. 243]. This tax should have been levied in the same amount on Western merchants in Caffa, as Francesco Balducci Pegolotti claimed in that part of his Trading Guide (La Pratica della Mercatura), which contained information on the conditions of trade in the Golden Horde in the first half of the 1320s ${ }^{27}$ : "Tax on goods paid in Caffa. All categories of people, with the exception of the Genoese, pay three percent for export and import. The Genoese pay three and a half percent: half a percent goes to the community of the Genoese themselves, and three percent there goes to the Lord of Caffa" 28 .

25 "Nuper namque aliquorum relatu non sine magna cordis amaritudine intellexi, quod aliqui dictorum fratrum peregrinancium qui extremam paupertatem cum Christo paupere et mendico voluntarie elegerunt, plus student in congregandis pecuniis quam viciis extirpandis et quod censetur periculosius nec nota caret proprietarii, dictas pecunias indebite mendicatas tenent in manibus mercatorum et contra statuta ordinis ipsas dispensant absque licencia prelatorum" [28, p. 314].

${ }^{26}$ See the reference to this act in [42, p. 162, note 145].

${ }^{27}$ Pegolotti reported in the same part that a sommo (in this case, the monetary unit) in Tana was equal to 190 aspers [15, p. 25], and this fully corresponded to the information contained in one resolution of the Venetian Senate of 22 September 1322 [19, p. 17]. Sommo's value later changed. So, in the decree of the Venetian Senate of 23 March 1333, a sommo was equated with 160 aspers [Senato. Deliberazioni. Misti. 16: Registro [23/03/1333 - 21/02/1335], fol. $1^{\mathrm{r}}$ ].

28 "Diritto di mercatantia che si paga in Caffa. Tutte maniere di genti salvo i genovesi pagano 3 per centinaio traendo e entrando. Gienovesi pagano $31 / 2$ per centinaio; e 'l mezzo è della comunità de' genovesi medesimi, e li 3 per centinaio sono del signore di Caffa" [15, p. 26]. 
This statement by Pegolotti is the first clear reference to duties on European goods at Caffa in favor of the Khan's treasury; and, perhaps, the desire to impose this tax or increase it to three percent (or impose a double duty on both import and export of goods) was the real reason for the repressions that Toqta Khan could resort to after the Genoese probably refused to pay this tax. Apparently, under the new Khan, the Genoese, however, were forced to accept this requirement, which allowed them to settle again in Caffa legally, just as the Venetians of Tana managed to do later, recognizing as legitimate the increase of comercium to five percent in 1347 after they were expelled from Tana by Janibeg Khan four years earlier ${ }^{29}$.

The fact that Pegolotti meant by the "Lord of Caffa" its "Emperor," that is, the Golden Horde Khan, is confirmed in only one decree of the Office of Gazaria of 30 August 1316. This resolution specified that the Genoese consul of Caffa, that is, the official representative of the metropolis, had no right to recognize his vassal dependence on the Khan of the Golden Horde, as well as, curiously, on his wife. At the same time, the same resolution specified that in this case the "Emperor" of the Golden Horde was meant by the expression the "Lord of Caffa": "He (consul) is also obligated to swear that he will not become a vassal of the Emperor or Lord or Empress or Lady of Caffa all the time while he will serve as consul",30.

In the rest of their decisions, functionaries of the Office of Gazaria carefully avoided clarifying Caffa's status within the Golden Horde and mentioning the fact that in reality Caffa was subordinate primarily to Özbeg Khan and then to the comune of Genoa. This ambiguous silence of this fact became the object of criticism of the Venetians at the beginning of the reign of Janibeg in connection with the starting of an open conflict of both maritime republics with the new Khan. Due to this conflict, the governments of Genoa and Venice entered into a mutual agreement on the conditions of the embargo prohibiting all trade operations on the territory of the ulus of Jöchi (from 1 July 1344 to 1 July 1345). However, the commune of Caffa not only did not comply with the conditions of the embargo ${ }^{31}$, but also allowed itself to appropriate the right to collect the former Khan's comercium inside the city. This fact is evidenced by a protocol drawn up in October 1344 by the ambassadors of Venice, Marco Ruzzini and Giovanni Steno, sent to Janibeg and presenting a note of protest to the Genoese during their long stay in Caffa: "And if you, gentlemen inspectors and ambassadors of the comune of Genoa, would like to say that one can trade in Caffa, in the desire to say that Caffa itself belongs to the comune of Genoa, and not to the Emperor Janibeg, we, inspectors and ambassadors of the comune of Venice, say that you cannot say this justifiably, since the comune of Genoa has the city of Caffa from the Emperor on certain conditions and under certain agreements, and that the Lord Emperor himself keeps in Caffa his rectors and officials who administer justice and resolve issues relating to all people, except for the Genoese. And these officials also on behalf of this Emperor charge the comercium amounting to three percent in the mentioned Caffa both from the Genoese and from any other persons, as they actually do in Tana. So

${ }^{29} \mathrm{Cfr}$. the first yarliq of Janibeg Khan dated 30 September 1342, determining the amount of comercium at three percent, and his second yarliq of 26 December 1347, which increased it to five percent [11, p. 262, 312].

30 "Teneatur eciam iuramento quod non efficietur uassallus imperatoris uel domini uel imperatricis uel domine de Caffa quamdiu in ipso consulatus officio fuerit” [43, col. 401].

${ }^{31}$ These conditions were often violated by the Venetians themselves [21, p. 272]. 
[it should] say that the comune of Genoa in the mentioned city of Caffa has jurisdiction only over the Genoese, and not any other person. And if you, gentlemen inspectors and ambassadors of the comune of Genoa, would like to say that you charge comercium in Caffa, we, inspectors and ambassadors of the comune of Venice, say that the comercium that you charge applies only to your Genoese, and that it is legal for you to charge it as from yours citizens. But you should not charge a comercium from any other person and solve their issues, because if someone would like to [say] that Caffa itself is not in the Empire of Emperor Janibeg, they could not say it reasonably and truthfully" 32 .

\section{REFERENCES}

1. Assini A. Akty, sostavlennye v Prichernomor'e i Sredizemnomor'e notariyami Filippo Fasheto i Franchesko da Sil'va v 1314-1315 gg. = Atti rogati nel mar Nero e nel Mediterraneo dai notai Filippo Fasceto e Francesco da Silva nel 1314-1315 [Acts rogated in the Black Sea Region and the Mediterranean by Notaries Filippo Fascheto and Francesco da Silva in 1314-1315]. Prichernomor'e v srednie veka, No. 10: Notai genovesi in Oltremare: Atti redatti a Caffa ed in altre località del Mar Nero nei secoli XIV e XV=Akty genuezskikh notariev, sostavlennye $v$ Kaffe $i v$ drugikh gorodakh Prichernomor'ya $v$ XIV$X V v v$. [Black Sea Region in the Middle Ages, No. 10: Acts of the Genoese Notaries Rogated in Caffa and in Other Cities of the Black Sea Region in the fourteenth and fifteenth century]. Karpov S.P. (ed.). St. Petersburg: Aleteia, 2018, pp. 31-176. (In Russian, Italian, Latin)

2. Antonin, archimandrite (Kapustin). Zametki XII-XV veka, otnosyashchiesya $\mathrm{k}$ krymskomu gorodu Sugdee (Sudaku), pripisannye na grecheskom Sinaksare [Notes of the twelfth to fifteenth century related to the Crimean city of Sugdeia (Sudak) added to the Greek Synaxarion]. Zapiski Odesskogo obshchestva istorii i drevnostey [Notes of the Odessa Society of History and Antiquities]. Odessa: In the city printing house, 1863, vol. 5, pp. 595-628. (In Greek, Russian)

3. Balard M. La Romanie génoise (XII ${ }^{e}-$ début du XV $V^{e}$ siècle). Rome: École Française de Rome, 1978. 2 Vols. 1008 p. (with continuous pagination). (In French)

4. Brătianu G.I. Recherches sur le commerce génois dans la Mer Noir au XIII ${ }^{e}$ siècle. Paris: Librairie orientaliste Paul Geuthner, 1929. 359 p. (In French)

5. Bullarium Franciscanum Romanorum Pontificum constitutiones, epistolae, diplomata tribus Ordinibus Minorum, Clarissarum et Poenitentium a Seraphico Patriarcha

32 "Et si per vos dominos sindicos et ambaxatores comunis Ianuae vellet dicere quod mercaciones possent fieri in Caffa, vollendo dicere ipsum Caffam esse communis Ianue et non Imperatoris Çanibec, nos sindici et ambaxatores communis Veneciarum dicimus quod hic dicere de racione non potestis, cum commune Ianue habeat terram Caffe ab Imperatore cum certis condicionibus et pactis et quod ipse dominus Imperator teneat in Caffa suos rectores et officialles qui faciunt iustixiam et racionem in omnibus gentibus excepto quam in Ianuensibus, qui officialles etiam nomine ipsius domini Imperatoris exigunt in dicto Caffa nomine comercli tria per centenario tam a Ianuensibus quam a quibuscumque alliis personis, sicut proprie ipsi faciunt in Tana, ita quod commune Ianue in dicta terra Caffa dicere iurisdicionem habere inter suos Ianuenses tantum et non in aliqua allia persona. Et si per vos dominos sindicos et ambaxadores commune Ianue vellet dicere quod vos in Caffa excucitis comerclum, nos sindici et ambaxatores communis Veneciarum dicimus quod comerclum quod excucitis est tantum solomodo a vestris Ianuensibus, quibus licitum est a vobis ipsum ab ipsis excutere tamquam a vestris civibus, sed a nulla aliqua allia persona comerclum non excucitis nec de racione facere non debetis, ita quod si aliquis vellet ipse Caffa non esset in Inperiio Imperatoris Çanibec, hoc de racione et cum veritate dicere non posset" [see the protocol's text in 7, p. 204, note 251]. 
Sancto Francisco ab eorum originibus ad nostra usque tempora concessa, Vol. V: Benedicti XI, Clementis V, Ioannis XXII monumenta. Eubel C. (ed.). Romae: Typis Vaticanis, 1898. lii +643 p. (In Latin)

6. Cherepnin V.L. (ed.). Pamyatniki russkogo prava, Iss. III: Pamyatniki prava perioda obrazovaniya russkogo tsentralizovannogo gosudarstva XIV-XV vv. [Monuments of Russian Law, Vol. 3: Legal Monuments of the Period of the Formation of the Russian Centralized State in the fourteenth and fifteenth century]. Moscow: State publishing house of legal literature, 1955. 527 p. (In Russian)

7. Ciocîltan V. The Mongols and the Black Sea Trade in the Thirteenth and Fourteenth Centuries. Willcocks S. (tr.). Leiden; Boston: Brill, 2012. 321 p.

8. Desimoni C. Intorno alla impresa di Megollo Lercari in Trebisonda. Lettera di Bartolomeo Senarega a Giovanni Pontano pubblicata dal socio Cornelio Desimoni. Atti della Società Ligure di Storia Patria. Genova: Tipografia del Reale Istituto sordo-muti, 1879, vol. 13, fasc. 3, pp. 495-536. (In Italian, Latin)

9. DeWeese D.A. Islamization and Native Religion in the Golden Horde. Baba Tükles and Conversion to Islam in Historical and Epic Tradition. University Park: Pennsylvania State University Press, 1994. xvii +638 p.

10. Di Cosmo N. Mongols and merchants on the Black Sea Frontier in the thirteenth and fourteenth centuries: convergences and conflicts. Mongols, Turks, and Others. Eurasian Nomads and the Sedentary World. Amitai R., Biran M. (eds). Leiden; Boston: Brill, 2005, pp. 391-424.

11. Diplomatarium veneto-levantinum sive acta et diplomata res venetas, graecas atque levantis illustrantia a. 1300-1350. Thomas G.M., Tafel T.L.F. (eds). Venetiis: Typis Marci Visentini, 1880. xxvi + 356 p. (In Latin, Italian)

12. Favereau M. Zolotaya Orda i Mamlyuki [The Golden Horde and Mamluks]. Zolotaya Orda v mirovoy istorii. Kollektivnaya monografiya [The Golden Horde in World History: A Collective Monograph]. Khakimov R.S. et al. (eds). Kazan: Marjani Institute of History of Tatarstan Academy of Sciences, 2016, pp. 334-353. (In Russian)

13. Fontes. Pontificia commissio ad redigendum codicem juris canonici orientalis, Series III, Vol. V, Tom. 2: Acta Romanorum pontificum ab Innocentio $V$ ad Benedictum XI (1276-1304). Delorme F.M., Tăutu A.L. (eds). Romae: Typis pontificae universitatis gregorianae, 1954. xvi +295 p. (In Latin)

14. Fontes. Pontificia commissio ad redigendum codicem juris canonici orientalis, Series III, Vol. VII, Tom. 2: Acta Ioannis XXII (1317-1334). Tăutu A.L. (ed.). Romae: Typis pontificae universitatis gregorianae, 1952. xix +302 p. (In Latin)

15. Francesco Balducci Pegolotti. La pratica della mercatura. Evans A. (ed.). Cambridge, Massachusetts: The Mediaeval Academy of America, 1936. liv + 443 p. (In Italian)

16. Gibb H.A.R. (tr.). The Travels of Ibn Battutta, A.D. 1325-1354. Cambridge: Published for the Hakluyt Society at the University Press, 1959, vol. II. xii +286 p.

17. Golubovich G. Biblioteca bio-bibliografica della Terra santa e dell'Oriente francescano, Tomo III: Dal 1300 al 1332. Quaracchi, Firenze: Collegio di S. Bonaventura, 1919. vi + 496 p. (In Italian, Latin)

18. Grigor'ev V.V. O dostovernosti yarlykov, dannykh khanami Zolotoy Ordy russkomu dukhovenstvu. Istoriko-filologicheskoe issledovanie [On the Authenticity of the Yarliqs of the Golden Horde Khans Granted to the Rus'ian Clergy. Historical and Philological Research]. Moscow: The University Press, 1842. 132 p. (In Russian)

19. Karpov S.P. Drevneyshie postanovleniya Senata Venetsianskoy respubliki o navigatsii v Chernom more [The oldest decisions of the Senate of the Venetian Republic on navigation in the Black Sea]. Prichernomor'e v srednie veka [The Black Sea Region in the Middle Ages]. Moscow; St. Petersburg: Aleteia, 2000, no. 4, pp. 11-18. (In Russian)

20. Karpov S.P. Istoriya Trapezundskoy imperii [History of the Trebizond Empire]. St. Petersburg: Aleteia, 2007. 618 p. (In Russian) 
21. Karpov S. Venezia e Genova: rivalità e collaborazione a Trebisonda e Tana, secoli XIII-XV. Atti della Società Ligure di Storia Patria, Vol. XLI (CXV), Fasc. I: Genova, Venezia, il Levante nei secoli XII-XIV. Atti del Convegno Internazionale di Studi. GenovaVenezia, 10-14 marzo 2000. Genova: Nella sede della Società Ligure di Storia Patria, 2001, pp. 257-272. (In Italian)

22. Khwand-Amir. Istoriya mongolov. Ot drevneyshikh vremen do Tamerlana [History of the Mongols. From the Most Ancient Times to Tamerlane]. Grigor'ev V. (tr.). St. Petersburg: At Karl Krai's printing house, 1834. (In Russian)

23. Loenertz R.-J. Les missions dominicaines en Orient au XIV siècle et la Société des Frères pérégrinants pour le Christ. Archivum Fratrum Praedicatorum. Romae: Institutum Historicum Fratrum Praedicatorum Romae ad S. Sabinae, 1932, vol. II, pp. 183. (In French)

24. Loenertz R.-J. La Société des Frères Pérégrinants. Étude sur l'Orient Dominicain. Roma: Istituto Storico Domenicano, 1937, vol. I. xii + 209 p. (In French)

25. Marco Polo. The Description of the World. Moule A.C., Pelliot P. (eds). London: George Routledge and Sons, 1938, vol. I. 595 p.

26. Mas-Latrie L. de. Privilège commercial accordé en 1320 à la République de Venise par un roi de Perse, faussement attribué à un roi de Tunis. Bibliothèque de l'École des chartes. Paris: Société de l'École des chartes, 1892, vol. 31, pp. 72-102. (In French, Italian)

27. Monleone G. Iacopo da Varagine e la sua Cronaca di Genova dalle origini al MCCXCVII, Vol. 1: Studio introduttivo. La vita e le opere di Iacopo da Varagine, $i$ manoscritti della Cronaca ecc. con un indice onomastico e quattro tavole fuori testo. Roma: Tipografia del Senato, 1941. xii + 577 p. (In Italian, Latin)

28. Monumenta Ordinis Fratrum Praedicatorum historica, Tomus V: Litterae encyclicae magistrorum generalium Ordinis Praedicatorum ab anno 1233 usque ad annum 1376. Reichert B.M. (ed.). Romae: Ex typografia polyglotta S.C. de Propaganda Fidei, 1900. $7+347$ p. (In Latin)

29. Moule A.C. Textus trium novorum documentorum e Tartaria Aquilonari an. 13141322. Archivum Franciscanum Historicum. Quaracchi, Firenze: Collegio S. Bonaventura, 1924, no. 17, pp. 65-71. (In Latin)

30. Myts V.L. Zavoevanie pozdnevizantiyskoy Tavriki mongolami: istorikoarkheologicheskiy kontekst katastrofy posledney chetverti XIII veka [The conquest of late Byzantine Taurica by the Mongols: historical and archaeological context of the disaster of the last quarter of the thirteenth century]. Stratum plus, No. 6: Pax Mongolica i evraziyskie potryaseniya XIII-XIV vv. [Pax Mongolica and Eurasian Shocks in the thirteenth and fourteenth centuries]. St. Petersburg; Chisinau; Odessa; Bucharest: University "Higher Anthropological School”, 2016, pp. 69-106. (In Russian)

31. Nystazopoulo M.G. He en te Taurike Chersoneso polis Sougdaia apo tou XII mechri tou XV â̂onos. Sumbole ê̂s ten historian tu mesaionikou Hellenismou tes Notiou Rosias. Athen: Hyperesia Archaiotētōn kai Anastēlōseōs, 1965. 188 p. (In Greek)

32. Ötemish Hajji. Kara tavarikh [Qara tavarikh]. Mirgaleev I.M., Sayfetdinova E.G., Khafizov S.T. (eds). Kazan: Marjani Institute of History of Tatarstan Academy of Sciences, 2017. (In Russian)

33. Pardessus J.M. Collection de Lois maritimes antérieures au XVIII ${ }^{e}$ siècle. Paris: Imprimerie royale, 1837, vol. IV. 609 p. (In French)

34. Pelliot P. Notes sur l'histoire de la Horde d'or: suivies de quelques noms turcs d'hommes et de peuples finissant en "ar". Paris: Librairie d'Amérique et d'Orient, Adrien Maisonneuve, 1949. 292 p. (In French)

35. Polnoe sobranie russkikh letopisey, Tom X: Letopisnyy sbornik, imenuemyy Patriarshey ili Nikonovskoy letopis'yu (prodolzhenie) [Complete Collection of Rus'ian Chronicles, Vol. 10: Chronicle Collection Called the Patriarchal or Nikon Chronicle (con- 
tinued)]. Bychkov A.F. (ed.). St. Petersburg: In the printing house of the Ministry of the Interior, 1885. $6+244$ p. (In Rusian)

36. Polnoe sobranie russkikh letopisey, Tom XVIII: Simeonovskaya letopis' [Complete Collection of Rus'ian Chronicles, Vol. 18: Simeonov's Chronicle]. Presnyakov A.E. (ed.). St. Petersburg: Printing house of M.A. Aleksandrov, 1913. iii + 316 p. (In Rusian)

37. Polnoe sobranie russkikh letopisey, Tom XXIII: Ermolinskaya letopis' [Complete Collection of Rus'ian Chronicles, Vol. 23: Ermolin's Chronicle]. Pokrovskiy F.I. (ed.). St. Petersburg: Printing house of M.A. Aleksandrov, 1910. 252 p. (In Rusian)

38. Polnoe sobranie russkikh letopisey, Tom XXIV: Tipografskaya letopis' [Complete Collection of Rus'ian Chronicles, Vol. 24: Typographical Chronicle]. Rozanov S.P., Shakhmatov A.A., Presnyakov A.E. (eds). Petrograd: Second State printing house, 1921. $\mathrm{xvi}+272$ p. (In Rus'ian)

39. Polnoe sobranie russkikh letopisey, Tom XXV: Moskovskiy letopisnyy svod kontsa XV veka [Complete Collection of Rus'ian Chronicles, Vol. 25: Moscow Chronicle Collection of the end of the fifteenth century]. Tikhomirov M.N. (ed.). Moscow; Leningrad: Publishing house of the USSR Academy of Sciences, 1949. 464 p. (In Rusian)

40. Polnoe sobranie russkikh letopisey, Vol. XXX: Vladimirskiy letopisets. Novgorodskaya vtoraya (Arkhivskaya letopis') [Complete Collection of Rus'ian Chronicles, Vol. 30: Vladimir Chronicle. Novgorod Second (Archival) Chronicle]. Tikhomirov M.N. (ed.). Moscow: Nauka, 1965. 239 p. (In Rusian)

41. Promis V. (ed.). Continuazione della Cronaca di Jacopo da Varagine. Atti della Società Ligure di Storia Patria. Genova: Tipografia del Reale Istituto sordo-muti, 1876, vol. 10, fasc. IV, pp. 493-512. (In Italian, Latin)

42. Richard J. La Papauté et les missions d'Orient au Moyen Âge (XIII ${ }^{e}-X V^{e}$ siècles). Rome: École Française de Rome, 1977. xxxiv + 331 p. (In French)

43. Sauli L. (ed.). Imposicio Officii Gazariae. Monvmenta Historiae Patriae. Leges mvnicipales. Avgvstae Tavrinorvm: E regio typographeo, 1838, vol. I, cols. 297-430. (In Latin)

44. Spuler B. Die Goldene Horde: Die Mongolen in Rußland, 1223-1502. Wiesbaden: Otto Harrassowitz, 1965. xviii + 638 p. (In German)

45. Tardy L. Madjar - The name of Eastern Hungarians in an Italian document from Caffa, 1310. Acta Antiqua Academiae Scientiarum Hungaricae = Acta Antiqua: A Journal of the Hungarian Academy of Sciences. Tomus XXX. Harmatta J. (ed.). Budapest: Akadémiai Kiadó, 1982-1984, pp. 451-456.

46. Tizengauzen V.G. Sbornik materialov, otnosyashchikhsya $k$ istorii Zolotoy Ordy, Tom 1: Izvlecheniya iz sochineniy arabskikh [Collected Materials Related to the Golden Horde History, Vol. 1: Excerpts from Arabic Writings]. St. Petersburg: Printing house of the Imperial Academy of Sciences, 1884. xvi + 563 p. (In Arabic, Russian)

47. Tizengauzen V.G. Sbornik materialov, otnosyashchikhsya $k$ istorii Zolotoy Ordy, Tom 2: Izvlecheniya iz persidskikh sochineniy [Collected Materials Related to the Golden Horde History, Vol. 2: Excerpts from Persian Writings]. Romaskevich A.A., Volin S.L. (eds). Moscow; Leningrad: Publishing house of the USSR Academy of Sciences, 1941. 306 p. (In Russian, Persian)

48. Wyngaert A. van den (ed.). Sinica Franciscana, Vol. I: Itinera et relationes fratrum minorum saeculi XIII et XIV. Quaracchi, Firenze: Collegio di S. Bonaventura, 1929. cxvii + 637 p. (In Latin) 
About the author: Roman Hautala - Ph.D. (History), Senior Research Fellow, Usmanov Center for Research on the Golden Horde and Tatar Khanates, Marjani Institute of History of Tatarstan Academy of Sciences (7A, Baturin Str., Kazan 420111, Russian Federation); Docent, Department of History at the Faculty of Humanities, University of Oulu, (1, Pentti Kaiteran Str., Historia, PL 1000, 90570, University of Oulu, Oulu, Finland); ORCID: 0000-0003-3898-0107, ResearcherID: H-9114-2016. E-mail: romanhautala@gmail.com

\title{
ПОТЕРЯ И ПОВТОРНОЕ ОБРЕТЕНИЕ КАФФЫ: СТАТУС ГЕНУЭЗСКОЙ ФАКТОРИИ В ГРАНИЦАХ ЗОЛОТОЙ ОРДЫ
}

\author{
Роман Хаутала ${ }^{1,2}$ \\ ${ }^{1}$ Институт истории им. Ш. Марджани АН РТ \\ Казань, Российская Федерачия \\ ${ }^{2}$ Университет Оулу \\ Оулу, Финляндия \\ romanhautala@gmail.com
}

Цель исследования: проанализировать обстоятельства как вооруженного конфликта генуэзцев Каффы с войсками золотоордынского хана Токты в 1307-1308 годах, закончившегося временным изгнанием итальянских купцов с джучидской территории, так и их возвращения в Каффу при племяннике и преемнике Токты, хане Узбеке.

Материалы исследования: информация о конфликте между генуэзцами и ханом Токтой содержится в анонимном продолжении хроники генуэзского архиепископа и хрониста Якопо да Вараджине середины XIV века, в хрониках мамлюкских авторов Рукн ад-дин Бейбарса и ан-Нувайри и в местном греческом источнике, а именно, в Сугдейском синаксаре. В свою очередь источники, которые предоставляют информацию об обстоятельствах и условиях возвращения генуэзцев, намного более разнообразны. Разумеется, наиболее важная информация содержится в официальный документах Генуи и Каффы. Очень ценные подробности содержатся в миссионерских источниках францисканцев, проповедовавших евангелие внутри Золотой Орды. Со своей стороны, францисканские сведения полезно сравнить с информацией русских источников касательно сношений католических и православных прелатов с ханом Золотой Орды.

Новизна исследования: использование францисканских источников для дополнения анализа взаимоотношений генуэзской фактории с местной властью представляется чрезвычайно полезным.

Результаты исследования: анализ конфликта генуэзцев с местной властью и условий их возвращения, обговоренных с новым ханом Золотой Орды, выявляет тот очевидный факт, что Каффа, несомненно разросшаяся в золотоордынский период благодаря деятельности генуэзских переселенцев, должна была признавать свое подчинение джучидским правителям с самого своего появления, и генуэзская администрация признала эту зависимость во время восстановления Каффы в первые годы правления хана Узбека. 
Ключевые слова: история Золотой Орды, итальянская торговля в Монгольской империи, генуэзская фактория Каффы, католическая миссионерская деятельность на востоке, латинские и мусульманские источники

Для цитирования: Hautala R. The Loss and Reacquisition of Caffa: The Status of the Genoese Entrepôt within the Borders of the Golden Horde // Золотоордынское обозрение. 2021. Т. 9, № 2. С. 247-263. DOI: 10.22378/2313-6197.2021-9-2.247-263

Сведения об авторе: Роман Хаутала - Ph.D. (история), старший научный сотрудник Центра исследований Золотой Орды и татарских ханств им. М.А. Усманова Института истории им. Ш. Марджани АН РТ (420111, ул. Батурина, 7А, Казань, Российская Федерация); доцент кафедры истории гуманитарного факультета университета Оулу, (90570, ул. Пентти Кайтера, 1, История, почтовый ящик 1000, университет Оулу, Оулу, Финляндия); ORCID: 0000-0003-3898-0107, ResearcherID: H-9114-2016. E-mail: romanhautala@gmail.com 


\title{
REFLECTIONS ON THE ISLAMIC LITERATURE OF THE GOLDEN HORDE: ON THE OCCASION OF THE PUBLICATION OF THE QALANDAR-NĀME
}

\author{
Uli Schamiloglu ${ }^{1,2}$ \\ ${ }^{1}$ Nazarbayev University \\ Nur-Sultan, Republic of Kazakhstan \\ uli.schamiloglu@nu.edu.kz \\ ${ }^{2}$ University of Wisconsin-Madison \\ Madison, USA \\ uschamil@wisc.edu
}

\begin{abstract}
This article was presented at a roundtable devoted to a discussion of the Qalandar-nāme. The author, basing himself on the 9 chapters of the monumental Qalandarnāme published to date with commentary, tries to compare this work with what else is known about Islamic civilization in the Golden Horde in this period. In particular, he examines the account of Ibn Batțūta and compares the Persian-language Qalandar-nāme with the Turkic works on the history of the prophets (Q1sas ül-änbiya), a Sufi manual ( $\mathrm{Mu}^{\mathrm{c}}$ in ülmürid), two romantic poems (Qutb's Xusrev u Şirin and Khorezmi's Muhabbätname), and a handbook of Islam (Nähc ül-färadis). The author finds similarities between the works of Sufi literature and the Qalandar-nāme. He concludes by posing a series of questions for future researchers, including whether this work can also be seen as a response to the Black Death, similar to the Nähc ül-färadis, as the author has argued elsewhere.
\end{abstract}

Keywords: Golden Horde, Qalandar-nāme, Nähc ül-färadis, Black Death

For citation: Schamiloglu U. Reflections on the Islamic Literature of the Golden Horde: On the Occasion of the Publication of the Qalandar-nāme. Zolotoordynskoe obozrenie $=$ Golden Horde Review. 2021, vol. 9, no. 2, pp. 264-271. DOI: 10.22378/23136197.2021-9-2.264-271

I am honored to share my brief reflections on the Nehc ül-feradis and other Islamic literary works written in the Golden Horde as well as sources about Islam in the Golden Horde on the occasion of the conference celebrating the publication of the Russian translation of the Qalandar-nāme and the opening of the Islamic Academy in Bolgar (September 3-5, 2017) ${ }^{1}$. Since I had not had an opportunity to study this work previously, except for the first 9 chapters which have been published separately in Russian translation, a more detailed study of the Qalandarnāme itself is most certainly a desideratum for the future.

According to the translators, editors, and commentators contributing to the Golden Horde Review, the Qalandar-nāme was a Persian-language work devoted to Islamic theology with a Sufi orientation written in Persian by Abū Bakr

${ }^{1}$ Originally presented as: "Nehc ül-feradis: Altın Urdadagı Islam turında beleşmä kitabı”, Roundtable on the Kalandarname/Conference on the Spiritual Silk Way. On the Occasion of the Opening of the Islamic Academy in Bolgar (Kazan/Bolgar, September 3-5, 2017). 
Qalandar Rūmī, a native of Aksaray in Anatolia. This wide-ranging work was written in the Golden Horde in the mid-fourteenth century C.E. during the time of the khans Muhammad Özbek and Canıbek. Abu Bakr Qalandar Rumi himself was a "Sufi, great scholar, [and] imam of a mosque in the city of Staryy Krym" [1, p. 251-252]. The first 9 chapters of this 800 page manuscript were published 2014-2016:

Chapter 1, "The Unity of God (Tavhīd)" [1]

Chapter 2, "Praise and Blessing upon Muhammad Muștafā" [2]

Chapter 3, "In Praise of Abū Bakr, Commander of the Faithful" [3]

Chapter 4, "In Praise of "Umar, Commander of the Faithful" [4]

Chapter 5, "In Praise of "Usmān, Commander of the Faithful" [5]

Chapter 6, "In Praise of 'Alī, Commander of the Faithful" [6]

Chapter 7, "In Praise of Hasan and Husayn, Commanders of the Faithful" [6]

Chapter 8, "In Praise of the Four Imāms" [7]

Chapter 9, "The Night Ascension $\left(M i^{c} r \bar{a} c\right.$ ) of the Prophet (Peace be upon $\operatorname{him} !) "[8]$

The rediscovery and publication of this work by Ilnur Mirgaleev, Head of the Usmanov Center for Research on the Golden Horde and Tatar Khanates of the Marjani Institute of History of Tatarstan Academy of Sciences, is certainly one of the greatest contributions to the study of Islam in the Golden Horde in the last 100 years or more. While it has been my rare privilege to obtain a copy of the facsimile of this work published earlier, I have not had the time to study it or the translation carefully yet $[9 ; 10]$. It appears that the serial publication of the translation with commentary is only at the beginning of a very long road to publication. Commenting on this work will no doubt occupy scholars for many years and decades to come. Nevertheless, we already have enough of a sense of what this work might be about to be able to contextualize it as a fundamental - though hitherto unknown to scholarship - product of the Islamic civilization of the Golden Horde. In the rest of my presentation I will try to contextualize this work within the range of other sources for the study of Islam in the Golden Horde.

So much of what we know about Islam in the Golden Horde is thanks to the detailed unique information offered by the great traveler Ibn Battūta. During his travels through the territory of the Golden Horde circa January 1333, Ibn Batțuta found mosques, religious judges, and Sufi hospices (zāwiya) to be ubiquitous. In the town of Q1rım, where he stayed in a hospice led by the sheykh Zāda al-Xurāsān̄, there was a chief religious judge ( $q \bar{a} d \bar{l})$ of the Hanafî legal school as well as religious judge of

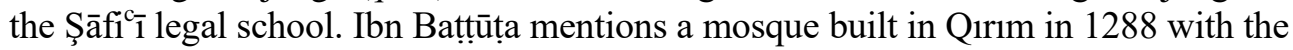
aid of the Egyptian ruler Baybars, but we also know of two other mosques, including the congregational mosque of Q1rım that Özbek had built in he found 1314 [16, ii, p. 470-473 and 472 n.]. In Kaffa he found a mosque and in Azaq (Azov) found a religious judge and students, and he also witnessed recitations of the Qur'ān followed by a sermon and blessings. There were also other kinds of religious singing in Arabic which were then translated into Persian as well as into Turkic.

In the great traveler's description Saray Berke was an exceptional city for its religious life as well. Saray had 13 mosques for Friday congregational prayers, including one for the Şāfi ${ }^{c} \overline{1}$ school, and there were many more smaller mosques. He 
met religious scholars there from around the central Islamic lands. In Xwarezm the great traveler found a great center of Islamic religion and learning which neither Saray Batu nor the more recently-established city of Saray Berke could possibly rival. (Time does not permit me to review this here, but this is a region whose history is more closely tied to the history of Islam in sedentary Central Asia.)

Ibn Battututa is a unique source for some many important topics. His account allows us to conclude that in Xwarezm and in Bulğar (the latter probably not visited by Ibn Batțūta), Islamic devotion continued - we might say from the perspective of the 1330s without serious disruption - from pre-Mongol times, though the Mongol conquests helped create important martyrs, especially among the leaders of Sufi orders in Xwarezm and elsewhere in Central Asia such as Nacm ad-Dīn al-Kubrā. It is difficult to say how old the Islamic infrastructure in the centers visited by the great traveler in the North Caucasus foreland and the Crimea might have been, but it can certainly predate the arrival of the Mongols by centuries as well.

The rapid development of orthodox Islamic institutions in Saray within the space of decades or possibly even just years was spectacular. Equally spectacular by the time of Ibn Battututa's visit was the full participation in religious life by the highest levels of the ruling elite, including Özbek Xan's humiliation before an ascetic religious leader. Every Friday, the Muslim day of rest, Özbek Xan would visit the hospice of the learned congregational preacher (imām) $\mathrm{Nu}^{\mathrm{c}} \mathrm{ma} n$ ad-Dīn alXwārizmī, "one of the eminent shaikhs and a man of fine character, generous in soul, of exceeding humility but also of exceeding severity towards the possessors of this world's goods". Although this sheykh would humble himself before poor brethren, the needy, and travelers, his conduct towards Özbek was the opposite.

The information provided us by Ibn Batțutta allows us to understand the role of the Sufi orders in promoting Islam among broader segments of the population throughout the religious frontier areas of the Golden Horde. As in the conversions of Berke and Özbek to Islam, the Sufi leaders must have participated in missionary activity among broader segments of society as they did in other periods. Perhaps it is already possible to speak of a missionary Islam propagated by Sufi orders in the territories of the Golden Horde in the time of Berke Xan. There can be no question that there was such a missionary Islam by the time of Özbek Xan, since the hospices described by Ibn Battututa were by their very nature intended to serve as nodes in an Islamic religious and missionary network throughout the territory of the patrimony of Batu.

We can now turn to the best-known Islamic Turkic texts which allow us to speak about Sufism in the world of the Golden Horde. The most prominent of these is Rabğuzi's Qısas ül-änbiya' ("Tales of the Prophets") [20; 21; 13, p. 276-279]. This important work, which later became one of the most popular works among the Muslim Turks of the Russian Empire in the nineteenth and early twentieth centuries, is a collection of stories about the Creation and the prophets from Adam through Muhammad and other early Islamic figures. It was composed around 1310 in Ribat-i Oğuz in Türkistan for a devout local Chinggisid, Nasirüddin Toqbuğa, who would cry while hearing verses from the recited [21, p. 7]. By the nineteenth century this work would be an important source of information on Islam for Tatars of the Volga-Ural region, who were taught by religious teachers who were influenced by the traditions of mystical Islam. 
Another work, the $\mathrm{Mu}^{c}$ in $\ddot{u} l$-mürid, was a short religious work composed in Ürgenç in 1313 [23;24;25;11;13, p. 279-280]. The contents of this work reveal it to have been intended for aspirants in a Sufi order because of its heavy emphasis on the attainment of mystical knowledge (mäc rifät) of God, the declaration of one's intention to become a mystic (iradät), otherwise without giving up his identity he cannot become a disciple (murid) of a Sufi shaykh, whom he must imitate (iqtida) and thereby become part of a community (suhba). The comparison is made to an arrow: Truth (haqiqat) is the tip of the arrow (arrowhead), the Sufi Order (tariqat) is the shaft of the arrow, and Religious Law (şäric ät) is the feathers at the end of the arrow (fletching). Making progress on the path (süluk) the novice will learn to give thanks (şükr) to God and to remember (zikr) the Holy Men (äränlär).

Other works from a bit later in the fourteenth century include the romantic poems Xusrev $u$ Şirin, which is adapted by Qutb from the Persian poem of the same name by Nizāmī [15; 27; and the discussion in 13, p. 280-285] and Xorezmi's romantic poem Mähabbätname (also: Muhabbätname) $[14 ; 17 ; 22$; and the discussion in 13, p. 285-287]. In addition to these two poems there is also the religious treatise Nehc ül-feradis (discussed below). All three of these later works diverge from the strong devotional character of the Qusas ül-enbiya' and the $M u^{c}$ in $\ddot{u} l$ murid. In contrast, the Persian-language Qalandar-nāme is situated solidly within the tradition of works exploring Islamic mystical knowledge.

A very different kind of pious religious work, not situated in the mystical tradition, is represented by the Nähc ül-färadis, which was intended as a pious work [18; 19; 20; and the discussion in 13, p. 287-291]. Already in the nineteenth century Şihabeddin Märcani described a manuscript of the Nähc ül-färadis (now lost) copied in Saray in 749/1358. That manuscript attributed the work to one Mahmud born in Bulğar, who found refuge in Saray, and whose family name (nisba), Kerderī, linked him with the city of Kerder in Xwarezm. Another manuscript says that the author died three days after March 25, 1360. The manuscript edited by Eckmann et al. was completed on 6 Cumādā I, 761/March 25, 1360, indicates the various sources on which it was drawn, and finally refers to the author as Muhammad b. Muhammad b. Xusräv el-Xorezmi. [12, p. 95; 18, p. 309; 19, p. 8].

This work is divided into four parts of ten chapters each. Part I, "The Positive Characteristics of the Prophet Muhammad", is a detailed account of his life, the revelation of Islam, the Hicra from Mecca to Medina, the miracles surrounding his life, his return to Mecca, the Prophet's ascent to heaven in a dream, an explanation of heaven, the battle of Huneyn, and his death. Part II, "The Positive Characteristics of the Orthodox Caliphs, the Prophet's Family, and the Four Imāms", includes accounts of the first four caliphs (Abū Bakr, 'Umar, 'Utmān, 'Alī), the Prophet's wife Fātima, the two sons Hasan and Husayn of ${ }^{c} \mathrm{Al} \overline{1}$ (who are seen as martyrs by the Shi ites), and the imāms who founded of the four major legal schools (the greatest imām Abū Hanīfa, imām Şāficīi, imām Mālik, imām Aḥmad Hanbal). Part III, "An Explanation of the Virtuous Deeds Bringing One Close to God" explains the virtues of praying five times a day, giving alms, fasting during Ramaḍān, making the pilgrimage to Mecca, treating parents with respect, eating religiously-pure (halāl) food, proper etiquette (including distinguishing good from evil), devotion at night, and patience and contentment. Part IV, "An Explanation of the Evil Deeds Distancing One From God", explains the evils of spilling blood unjustly, fornication, drinking alcoholic beverages, haughtiness, lying, loving this world, hypocrisy 
and dissimulation (riy $\bar{a}$ ve $\operatorname{sem}^{c} a$ ), malice and envy, hubrus and neglect, and the hope of a long life.

As I have argued elsewhere, the contents of this work reveal it to have been a work of an orthodox Sunnī character simply describing the basic knowledge and precepts that one needs to be a good Muslim. It includes balanced information on all the Muslim legal schools, reflecting the composition of Sunnī legal scholars in the cities of the Golden Horde as described by Ibn Battūța. If I we compare it with handbooks for Sufi orders in this period, this work was not designed for a murid, an aspirant in a Sufi order, as discussed above [26].

The existence of both traditions begs the question of whether there might have been any tensions between these two separate views of religion. After all, orthodox Islam was apparently dominant in the cities of the Golden Horde along the Volga, while in Xwarezm and elsewhere in the south there was a strong Sufi tradition that had even served a prominent role in the conversion of Berke Xan to Islam. We cannot know whether the Nähc ül-färadis was intended to serve as an educational purpose or if it was simply a pious act on the part of the author.

In this regard, there is one further observation that I would offer in this regard, namely that there was an increase in a desire to learn about how to get to heaven, if we may recall the subtitle to this work. This could be a function of the fact that the number of converts to Islam was increasing. As I have argued elsewhere, however, this was also the period of the ravages of the Black Death through the territories of the Golden Horde. As in Western Europe, the Black Death must have had a profound impact on society in these territories as well. In Western Europe, one of the responses was an increased religiosity, a greater concern with death and the punishments brought down by God in art and literature. There is no doubt in my mind that the population of the Golden Horde had many reasons to be concerned about whether it got to heaven or not, and that this work was connected with that fear. I see the creation of this work in the Islamic Turkic literary language of the Golden Horde as a pious act in order to be a better, more pious Muslim by reproducing a work to teach others about the basic principles of Islam. This should be understood as a response to the punishment unleashed by God in the form of the Black Death (and possibly other diseases) in the mid-fourteenth century.

Finally let us return to the topic of our roundtable, namely Abū Bakr Qalandar Rūmī's Qalandar-nāme, which was also written in the mid-fourteenth century during the reigns of Özbek Khan and Canıbek Khan. To conclude, based upon just a passing familiarity with this work from 9 chapters published so far in the Golden Horde Review, I would raise a number of questions about this work:

1. To what extent did the Qalandar-näme (in Persian) draw upon the same sources as the Nähc ül-färadis (in Turkic)?

2. Could the Qalandar-nāme have served as a source for the Nehc ül-feradis? In my superficial understanding of the Qalandar-nāme, it is a much more detailed text including many elements of Sufism.

3. If there is any relationship between these two texts, did the Nähc ül-färadis strip its content down to the basics of Orthodox Islam? (Whether there is any relationship or not, it is worth comparing the Qalandar-nāme with the Nähc ül-färadis to bring the religious and ideological orientation of the Qalandar-näme into sharper focus). 
4. I have argued elsewhere that the composition of the Nähc ül-färadis as a response to plague and the different possible dates for the death of the author/copyist coincides perfectly with what we know about the chronology of the waves of Black Death visiting the Middle Volga region and the end of the Volga Bulgarian language (a Western Turkic epigraphical language used for funerary inscriptions). Since the Qalandar-name is written in the same period (but beginning in the reign of Özbek Khan, presumably closer to the time of his death in 1343 than the beginning of his reign in 1313), is there evidence to suggest that the Qalandar-name was also an example of increased religiosity in this period, in other words also a response to the Black Death of the fourteenth century? If the work was written in the Crimea, there is sufficient evidence for waves of plague in the Crimea, too. I suspect that the answers to these and other questions will occupy us for a long time yet...

\section{REFERENCES}

1. Abu Bakr Qalandar. Qalandar-name. Chapter 1. "Monotheism”. Ismagilova M.R. (tr.), Shagaviev D.A. (ed.). Golden Horde Review, 2014, no. 2, pp. 243-252. (In Russian)

2. Abu Bakr Qalandar. Qalandar-name. Chapter 2. "Praise and blessing upon Muhammad Mustafa". Ismagilova M.R. (tr.), Shagaviev D.A. (ed.). Golden Horde Review, 2014, no. 3, pp. 207-214. (In Russian)

3. Abu Bakr Qalandar. Qalandar-name. Chapter 3. "Praises to Abu Bakr, Commander of the Faithful". Ismagilova M.R. (tr.), Shagaviev D.A. (ed.). Golden Horde Review, 2014, no. 4, pp. 198-207. (In Russian)

4. Abu Bakr Qalandar. Qalandar-name. Chapter 4. "Praising 'Umar, Commander of the Faithful”. Ismagilova M.R. (tr.), Shagaviev D.A. (ed.). Golden Horde Review, 2015, no. 1, pp. 171-177. (In Russian)

5. Abu Bakr Qalandar. Qalandar-name. Chapter 5. "The praise of 'Uthman, Commander of the Faithful”. Ismagilova M.R. (tr.), Shagaviev D.A. (ed.). Golden Horde Review, 2015, no. 2, pp. 187-196. (In Russian)

6. Abu Bakr Qalandar. Qalandar-name. Chapter 6. "Praising 'Ali, Commander of the Faithful". Chapter 7. "Praising Hasan and Hussein, Commanders of the Faithful". Shamsimukhametova M.R. (tr.), Shagaviev D.A. (ed.). Golden Horde Review, 2016, no. 1, pp. 193-207. (In Russian)

7. Abu Bakr Qalandar. Qalandar-name. Chapter 8. "Praises to Four Imams". Shamsimukhametova M.R. (tr.), Shagaviev D.A. (ed.). Golden Horde Review. 2016, vol. 4, no. 2, pp. 443-449. (In Russian)

8. Abu Bakr Qalandar. Qalandar-name. Chapter 9. “The Ascension (Mi'raj) of the Messenger [of Allah] (Peace Be upon Him!)". Gibadullin I.R. (tr. and ed.), Shamsimukhametova M.R. (tr.). Golden Horde Review. 2016, vol. 4, no. 4, pp. 861-867. DOI: 10.22378/2313-6197.2016-4-4.861-867. (In Russian)

9. Abu Bakr Qalandar Rumi. Qalandar-name. Facsimile. Mirgaleev I.M. (ed.). Kazan: Marjani Institute of History of Tatarstan Academy of Sciences, 2015. 800 p. (In Persian)

10. Abu Bakr Qalandar Rumi. Kalandar-name: izbrannoe [Qalandar-name: Selected Parts]. Gibadullin I.R. (tr. and ed.), Shamsimukhametova M.R. (tr.). Kazan: Marjani Institute of History of Tatarstan Academy of Sciences, 2017. 1044 p. (In Russian)

11. Bodrogligeti A.J.E. The authorship and sources of the Muinu'l-murid. Tractata Altaica: Denis Sinor, Sexagenario Optime de Rebus Altaicis Merito Dedicata. Heissig W. et al. (eds). Wiesbaden: Harrassowitz, 1976, pp. 87-105. 
12. Bombaci A. Histoire de la littérature turque. Mélikoff I. (tr.). Paris, 1968. 437 p. (In French)

13. Eckmann J. Die kiptschakische Literatur, I: Die Literatur von Chwarezm und der Goldenen Horde. Philologiae Turcicae Fundamenta. Boratov P.N. (ed.). Wiesbaden, 1964, vol. II, pp. 275-296. (In German)

14. Gandjeï T. Il 'Muhabbatnāma' di Horazmī. Annali dell'Instituto Universitario Orientale de Napoli. N.S. 1957, no. 6, pp. 131-161; 1958, no. 7, pp. 135-166. (In Italian)

15. Hacıeminoğlu M.N. Kutb’un Husrev ü Şirin’i ve dil hususiyetleri. Istanbul, 1968. 477 p. (In Turkish)

16. Ibn Bațūtata. The Travels of Ibn Battututa, A.D. 1325-1354. Gibb H.A.R (tr.). Cambridge, 1958-1971. xvii $+269 \mathrm{p}$.

17. Nadjip E.N. Khorezmi. Mukhabbat-name. Moscow, 1961. $224+48$ p. (In Russian)

18. Nehcü'l-ferādīs. Uştmahlarnıng açuq yolı (Cennetlerin açık yolu). Eckmann J. et al. (eds). Ankara: Atatürk Kültür, Dil ve Tarih Yüksek Kurumu, 1995. 2 Vols. (In Turkish)

19. Mäxmüd äl-Bolgari. Nähcel-färadis. Nurieva F. (ed.). Kazan, 2002. (In Tatar)

20. Rabğuzi Nosiruddin Burhonuddin. Kıșașü'l-Enbiyā (Peygamber Kıssalarl). Ata A. (ed.). Ankara, 1997-1998. 3 Vols. (In Turkish)

21. Rabğuzi Nosiruddin Burhonuddin. The Stories of the Prophets. Qisas al-anbiyā', An Eastern Turkish Version. Boeschoten H.E. et al. (eds and tr.). Leiden: Brill, 1995. 787 p. (In Turkish)

22. Shcherbak A.M. Oguz-name. Mukhabbat-name. Pamyatniki drevneuygurskoy $i$ starouzbekskoy pis'mennosti [Written Sourses of Ancient Uigur and Old Uzbek Writing]. Moscow: Oriental literature, 1959. 172 p. (In Russian)

23. Togan Z.V. Harezm'de Yazılmış Eski Türkçe Eserler. Türkiyat Mecmuası. 1928, vol. 2, pp. 315-345. (In Turkish)

24. Toparlı R. Mu'înü'l-Mürîd. Erzurum, 1988. lxxii + 287 p. (In Turkish)

25. Mu'inü'l-Mürid. Toparlı R. and Argunşah M. (eds). Ankara, 2015. 332 p. (In Turkish)

26. Waley M.I. A Kubrawī manual of Sufism: The Fușūṣ al-ādāb of Yahyā Bākharzī. The Legacy of Mediaeval Persian Sufism. Lewisohn L. (ed.). New York, 1992, pp. 289310.

27. Zajaczkowski A. Najstarsza wersja turecka Husräv u Šìīn Quṭba. Warsaw, 1958, vol. 1. 304 p. (In Polish)

About the author: Uli Schamiloglu - Ph.D. (History), Professor, Nazarbayev University (53, Kabanbay Batyr Ave, Nur-Sultan 010000, Republic of Kazakhstan); Professor Emeritus, University of Wisconsin-Madison (1220 Linden Drive, Madison, WI 53706, USA). E-mail: uli.schamiloglu@nu.edu.kz, uschamil@wisc.edu 


\title{
РАЗМЫШЛЕНИЯ ОБ ИСЛАМСКОЙ ЛИТЕРАТУРЕ ЗОЛОТОЙ ОРДЫ: ПО СЛУЧАЮ ПУБЛИКАЦИИ КАЛАНДАР-НАМЕ
}

\author{
Юлай Шамильоглу ${ }^{1,2}$ \\ ${ }^{1}$ Назарбаев Университет \\ Нур-Султан, Республика Казахстан \\ uli.schamiloglu@nu.edu.kz \\ ${ }^{2}$ Висконсинский университет в Мадисоне \\ Мадиссон, США \\ uschamil@wisc.edu
}

Цель исследования: эта статья была прочитана на круглом столе, посвященном обсуждению Каландар-наме. Автор, основываясь на 9 главах монументальной Каландар-наме, опубликованных на сегодняшний день с комментариями, пытается сравнить это произведение с тем, что еще известно об исламской цивилизации в Золотой Орде в этот период.

Материалы исследования: в частности, он рассматривает рассказ Ибн Баттуты и сравнивает Каландар-наме на персидском языке с тюркскими литературными произведениями по истории пророков (Кысас ул-анбия), суфийским справочником (Муин ул-мурид), двумя романтическими стихотворениями (Хусрев у Ширин Кутба и Мухаббатнаме Хорезми), а также справочником по исламу (Нахдж ул-фарадис). Автор находит сходство между произведениями суфийской литературы и Каландар-наме.

Результаты исследования и научная новизна: в заключение автор задает ряд вопросов будущим исследователям, в том числе: можно ли рассматривать эту работу как ответ на «Черную смерть», подобную Нахдж ул-фарадис, как он утверждал в другом месте.

Ключевые слова: Золотая Орда, Каландар-наме, Нахдж ал-Фарадис, Черная смерть

Для цитирования: Schamiloglu U. Reflections on the Islamic Literature of the Golden Horde: On the Occasion of the Publication of the Qalandar-nāme // Золотоордынское обозрение. 2021. Т. 9, № 2. С. 264-271. DOI: 10.22378/2313-6197.2021-92.264-271

Сведения об авторе: Юлай Шамильоглу - Ph.D. (история), профессор, Назарбаев Университет (010000, пр. Кабанбай батыра, 53, Нур-Султан, Республика Казахстан); профессор, Висконсинский университет в Мадисоне (1220 Linden Drive Drive, Madison, WI 53706, USA). E-mail: uli.schamiloglu@nu.edu.kz, uschamil@wisc.edu 


\title{
СЕДЕНТАРИЗАЦИЯ СРЕДНЕВЕКОВЫХ КОЧЕВНИКОВ ВОСТОЧНОЙ ЕВРОПЫ: ПОНИМАНИЕ И ПРОЯВЛЕНИЕ
}

\author{
В.А. Иванов \\ Башкирский государственный педагогический \\ университет им. М. Акмулль \\ Уфа, Российская Федеращия \\ ivanov-sanych@inbox.ru
}

Цель: показать, что, вопреки мнению многих исследователей истории и культуры кочевников эпохи средневековья, седентаризация (переход к оседлому образу жизни) не являлась ни самоцелью, ни итогом естественноисторического развития кочевых обществ.

Maтериаль исследования: в основу работы легли результаты источниковедческого анализа данных археологии, средневековых письменных источников и трудов ученыХ-путешественников XVIII-XIX вв., описывавших образ жизни и менталитет тюркских и монгольских кочевников, обитавших в это время в степях Евразии.

Результаты и научная новизна: методическое обеспечение концепции постепенного, но последовательного перехода кочевников к оседлости советскими исследователями осуществлялось через построение трехступенчатой схемы: первая (таборная) стадия, археологически представленная редкими археологическими памятниками в степи; вторая (полукочевая) стадия, проследить которую можно по появлениям в степи стационарных курганных могильников и поселений, маркирующих места кочевнических зимовок; третья стадия (оседлость), выраженная в появлении кочевнических могильников вблизи городов и отложении элементов материальной культуры кочевников в культурных слоях средневековых городов. Однако углубленный анализ следов номадической культуры на территории болгарских и золотоордынских городов показывает, что в общем комплексе городской культуры они занимали крайне незначительное место. Свидетельства средневековых нарративистов указывают на индифферентное отношение основной массы кочевников к городам. Наблюдения путешественников XVIII-XIX вв. подтверждают и дополняют наблюдения средневековых авторов. А историко-этнографические и социологические данные, полученные отечественными и зарубежными исследователями первой половины $\mathrm{XX}$ в., указывают на то, что седентаризация кочевых народов - казахов, калмыков, монголов - в состоянии которой они вошли в XXI век, есть следствие социальной политики советской власти, заинтересованной в установлении жесткого контроля над кочевниками. Bblвод, вытекающий из результатов исследования, следующий: «первая стадия кочевания» - это фактически миграция кочевников в поисках новых мест обитания; «вторая стадия» - наиболее естественная форма существования кочевых сообществ, единственно возможная в природно-географических условиях Евразийских степей (правы те исследователи, кто считал и считает так); «третьей стадии кочевания» не было вообще, поскольку принудительный переход к ней уже не есть кочевание.

Ключевые слова: седентаризация, номады, кыпчаки/половцы, Золотая Орда, курганы 
Для цитирования: Иванов В.А. Седентаризация средневековых кочевников Восточной Европы: понимание и проявление // Золотоордынское обозрение. 2021. T. 9, № 2. C. 272-295. DOI: 10.22378/2313-6197.2021-9-2.272-295

\title{
SEDENTARIZATION OF THE MEDIEVAL NOMADS OF EASTERN EUROPE: UNDERSTANDINGS AND MANIFESTATIONS
}

\author{
V.A. Ivanov \\ Bashkir State Pedagogical University named after M. Akmulla \\ Ufa, Russian Federation \\ ivanov-sanych@inbox.ru
}

\begin{abstract}
Research objectives: To demonstrate that, contrary to the opinion of many researchers of the history and culture of nomads during the Middle Ages, sedentarization (the transition from a nomadic to settled lifestyle) was neither an end in itself nor the result of a natural historical development of nomadic societies.

Research materials: This study is based on a source analysis of archaeological data, medieval written sources, and the works of travelers of the eighteenth and nineteenth centuries who described the lifestyle and mentality of the Turkic and Mongol nomads who lived in the steppes of Eurasia at that time.

Results and novelty of the research: Soviet researchers explained the gradual but sequential transition of nomads to a settled lifestyle through the methodology of a threestaged scheme: 1) the tabor stage represented by rare archaeological sites in the steppe; 2) the semi-nomadic stage with the appearance of stationary burial mounds and settlements in the steppe, which marked the places of nomadic wintering; 3) the stage of settlement with the appearance of nomadic burial grounds near cities and the deposition of elements of the material culture of nomads in the cultural layers of medieval cities. However, an indepth analysis of traces of nomadic culture in the territory of the Bulgar and Golden Horde cities shows that they occupied an extremely insignificant place in the general complex of urban culture. Medieval narrative sources indicate the indifferent attitude of the bulk of nomads to cities. The observations of travelers of the eighteenth and nineteenth centuries confirm and supplement the information recorded by medieval authors. Historical, ethnographic, and sociological data of domestic and foreign researchers in the first half of the twentieth century indicate that the sedentarization of Kazakhs, Kalmyks, and Mongols was a consequence of the social policy of the Soviet government, which was interested in establishing strict control over nomads. As such, the author drew the following conclusions: 1) the "first stage of nomadism" was actually the migration of nomads in search of new habitats; 2) the "second stage" was the most natural and the only possible form of existence of nomadic communities in the natural and geographical conditions of the Eurasian steppes (those researchers are correct who thought and still think so); 3) there was no "third stage of nomadism" at all, since nomads cease to be nomads per se after their forced transition to this stage.
\end{abstract}

Keywords: sedentarization, nomads, Kipchaks / Polovtsy, Golden Horde, barrows

For citation: Ivanov V.A. Sedentarization of the Medieval Nomads of Eastern Europe: Understandings and Manifestations. Zolotoordynskoe obozrenie $=$ Golden Horde Review. 2021, vol. 9, no. 2, pp. 272-295. DOI: 10.22378/2313-6197.2021-9-2.272-295 
Вопрос о седентаризации средневековых кочевников степной Евразии в современной историографии рассматривается в формате исторического дискурса. В контексте модернистской и постмодернистской истории это логично. Однако встает вопрос: насколько предлагаемые дискурсы адекватны той исторической ситуации, которая отражена в письменных и археологических источниках ${ }^{1}$.

Прежде всего, очевидно, следует вспомнить, что седентаризаџия - это процесс перехода кочевников к оседлому образу жизни.

Что же касается дискурса, то в философском понимании это речемыслительная деятельность, основанная на комплексе регулятивных принципов, следование которым оптимизирует процесс создания, трансляции и использования знаний (выделено мной $-a в m$.). Среди этих принципов основными являются объективность, установка на поиск истины, концептуальность (теоретичность), эмпиричность, логичность, методологичность, обоснованность, критицизм и креативность [28, с. 4-8].

Дискурс в устной форме предполагает диалог, то есть, собственно дискуссию. Она бывает кратковременной и, чаще всего, быстро забывается. Влияние текст-дискурса на сознание и мышление аудитории гораздо глубже, поскольку «дискурс, порожденный текстом, формирует в сознании людей особый способ видения мира, заменяя реальный мир на виртуальный. Осознание того, что информация, содержащаяся в тексте, образует дискурс, способствовало созданию текстов, а, следовательно, и дискурса, в котором доминировала Miracle Reality ${ }^{2}$, приводящая к дисгармонии между реальным миром и виртуальным, сконструированным посредством языка. Дискурс, стирая границы между реальностью и виртуальностью, позволяет создать некий иллюзорный мир 'of smoke and mirrors' ${ }^{3}$, в котором господствует стратегия искажения истины, позволяющая манипулировать сознанием масс» [40]. В XXI веке именно такая ситуация сложилась в восприятии и оценке исследователями процесса седентаризации у кочевников эпохи средневековья. Обратимся к примерам.

Для классиков отечественного номадо- и золотоордыноведения П.В. Голубовского, Г.В. Вернадского - проблема седентаризации кочевников, по-видимому, не стояла. В их представлении кочевники - они и были кочевники. Поэтому первый из названных ученых, характеризуя внутренний мир кочевников Восточной Европы, фактически ограничился ремаркой о том, что «... из всех известных нам степняков большей способностью к принятию культуры, к усвоению себе более совершенного быта соседей, - были половцы. Мы видели уже, что половцы жили в Тмуторокани. Но ко времени нашествия татар в их руках был уже и Судак. Это, по словам Ибн-эль-Асира, был главный половецкий город, обильный источник их богатства, потому что он на море Хазарском. К нему приходят суда с одеждами и покупают и выменивают на невольниц и невольников, чернобурых лисиц, бобров, белок и другие товары, находящиеся в их земле.

Благодаря этим сношениям роскошная жизнь половецких ханов являлась вполне естественной. Должно быть, она была уже очень заманчива, если вен-

\footnotetext{
${ }^{1}$ Насколько сами нарративы аутентичны исторической реальности - вопрос особый.

${ }^{2}$ Чудесная реальность.

3 Дыма и зеркал.
} 
герские вельможи стали подражать им и вызвали целую бурю со стороны католического духовенства Венгрии... Мы не знаем, сеялось ли просо самими кочевниками. Может быть, это был единственный продукт их собственного земледельческого труда» [14, с. 179-180].

Г.В. Вернадский внутреннее состояние Золотой Орды характеризовал следующим образом: ${ }^{4}$ «С экономической точки зрения Золотая Орда представляла собой симбиоз кочевого и оседлого населения (выделено мной $a в m.) .$. Как хан, так и князья часть года жили в городах, а на протяжении другой части года следовали за своими табунами. Большинство из них владело также земельными угодьями. Значительная часть городского населения проживала там постоянно, так что был создан городской класс, состоявший из разнообразных этнических, социальных и религиозных элементов» [10, с. 216-217].

Фактически проблема седентаризации кочевников в отечественной историографии впервые была обозначена в трудах советских исследователей. И это закономерно, поскольку советская историческая наука развивалась в концепте марксистской теории общественно-экономических формаций. Согласно этой теории, переход от варварства (родового строя) к цивилизации (государству) означает, во-первых, переход от пастушества к полеводству, поскольку «в климатических условиях Туранской равнины невозможна пастушеская жизнь без запасов корма на долгую и суровую зиму; луговодство и культура зерновых были здесь, таким образом, необходимы. То же самое следует сказать о степях к северу от Черного моря». Во-вторых, само по себе появление городов означало новый этап в общественной жизни, поскольку «в их рвах зияет могила родового строя, а их башни достигают уже цивилизации» $[65$, с. $72-73]$.

Обобщенно советскую концепцию номадизма можно изложить так: кочевничества в «чистом» виде не существовало. Оно всегда было представлено тремя формами: таборное (постоянное) - это когда кочуют постоянно, но только в тех местах, где для этого есть соответствующие пространственные и экологические условия; полукочевое - это когда племя в теплое время кочует в определенных для этого пределах, а зиму проводит в поселениях-зимниках (кышлаках); полуоседлое - это когда кочует только элита общества, а неимущая его часть постоянно обитает на поселениях, куда элита возвращается зимовать.

Одним из первых эту схему изложил Г.А. Федоров-Давыдов в своей монографии, посвященной культуре и истории средневековых кочевников Восточной Европы. Оперируя в основном археологическими источниками, исследователь выделяет признаки, свидетельствующие о постепенной седентаризации кочевых племен. К ним он относит, во-первых, появление кочевнических могильников или групп курганов, что свидетельствует об упорядочении маршрутов перекочевок, сезонности перекочевок уже по устойчивым маршрутам: «эти маршруты приводят из года в год кочевой коллектив на одно и то же место в степи, где и возникает могильник.

На сравнительно короткий срок, зимой, печенеги, торки и половцы устраивались на поселение, представлявшее сосредоточие юрт, кибиток и посто-

\footnotetext{
4 Заметим, что и тот, и другой исследователь опирались только на нарративные ис-
} точники. 
янных домов на заброшенном старом городище, стены которого, подновленные и реставрированные, могли еще служить убежищем. Здесь же, видимо, велось и земледельческое хозяйство» [56, с. 199-200].

Во-вторых - появление у кочевников грунтовых (бескурганных) могильников.

В-третьих - появление у кочевников долговременных городков в степи, каковыми, по свидетельству русской летописи, являлись Шарукань, Сугров, Балин, Канев, Торческ, Юрьев. Следует отметить, что городки эти известны только по летописным данным, археологами они до сих пор не найдены и, соответственно, не исследовались. Однако дело в том, что исследователи - и сам Г.А. Федоров-Давыдов, и его предшественники - считали, что заселяли эти городки не половцы, а т.н. «бродники», которые, «были специфической военной категорией населения, составляя русские отряды, примкнувшие к кочевым группам (выделено мной - asm.). На зимовищах типа верхнего слоя Белой Вежи жило и обычное мирное население, сотрудничавшее и, быть может, зависимое от кочевников».

В-четвертых, свидетельством перехода кочевников к оседлости являлось, по мнению исследователя, их проникновение в среду жителей больших городов. На это указывает присутствие кочевнической керамики в керамических комплексах таких городов как Саркел-Белая Вежа и Тмутаракань [56, с. 203204]. Своеобразным апофеозом процесса седентаризации у кочевников Восточной Европы он считал расселение и оседание кыпчаков/половцев в золотоордынских городах. На это, по мнению автора, указывает наличие погребений с кочевническим инвентарем на городских мусульманских некрополях Золотой Орды, а также зафиксированные в письменных источниках литературные произведения, написанные на языке кипчаков/половцев.

Правда, следует отметить, что Г.А. Федоров-Давыдов не преувеличивал масштабы кипчакской/половецкой седентаризации, считая ее следствием административной политики золотоордынских ханов, «чьи усилия были направлены на то, чтобы руками покоренных народов и вывезенных из покоренных стран ремесленников в короткий срок построить большие торговоремесленные центры на важнейших путях мировой торговли» [56, с. 209]. Но и в этом случае полной седентаризации кочевников не произошло, и в Золотой Орде сложились две разные культуры: «культура половцев степи, продолжавшая традиции кочевнической культуры восточноевропейской степи XII-XIII в., и синкретическая культура золотоордынского города» [56, с. 210].

Альтернативную точку зрения на исторические судьбы кочевников Евразии в те же времена выдвигал Г.Е. Марков. По его мнению, подкрепляемому неоднократными ссылками на выводы казахского историка С.Е. Толыбекова, «прогрессивное развитие кочевого скотоводческого общества всегда и везде должно было приводить к оседанию (выделено мной - aвm.)» [37, с. 287] $]^{5}$. Основным условием существования кочевничества как самостоятельной формы хозяйства исследователь считал сочетание частной собственности на скот и общинной собственности на пастбища. Окончательное закрепление определенных пастбищ за скотоводами - признак начала разложения кочевничества, перехода к полуоседлому (отгонному) или интенсивному оседлому

\footnotetext{
${ }^{5}$ Первое издание книги Г.Е. Маркова - 1976 г.
} 
хозяйству: «Кочевничество могло существовать лишь до тех пор, пока большая часть народа имела возможность беспрепятственно вести экстенсивное хозяйство, свободно кочевать» [37, с. 299]. Неизбежный процесс имущественного и социального расслоения кочевников, особенно усиливавшийся в период кочевых империй, «наряду с другими социально-экономическими явлениями приводил к переходу к более прогрессивному, интенсивному, но уже не кочевническому ${ }^{6}$ виду хозяйства. Общество было дифференцировано на социальные слои, которые в условиях кочевых империй в некоторых случаях приобретали характер сословий, а при разложении кочевничества становились классами» [37, с. 305].

Апофеозом решения проблемы седентаризации кочевников в советской историографии явилась концепция трех стадий кочевания, разработанная С.А. Плетневой. Опираясь на данные археологии и письменных источников, исследователь на примере кочевников Евразии показывает последовательный их переход от первой (таборной) стадии кочевания к последней третьей стадии, т.е. практически - оседлости.

Первая (таборная) стадия, для которой характерно отсутствие археологически фиксируемых следов, кроме разбросанных в пространстве отдельных погребений - это гунны, печенеги и половцы на раннем этапе их появления в степях Восточной Европы. Ее вызывало стремление кочевников к «приобретению любой ценой новых пастбищ, максимальное расширение территории для выпаса стад и охоты» [49, с. 14-17].

Переход ко второй стадия кочевания «означает прежде всего ограничение территории кочевания для каждой орды или рода и соответственно появление постоянных мест для сезонных стойбищ - зимовок и летовок (выделено мной - aвm.)». По мнению исследователя, это - наиболее характерная для кочевников форма хозяйствования. Вокруг зимовок появляются поля, обрабатываемые беднейшей частью кочевого общества. Рядом появляются стационарные могильники: «итак, следы стойбищ в виде обломков посуды и костей на берегах рек, бескурганные и курганные могильники рядом с ними и святилища - вот те основные материалы, типичные для второй стадии кочевания, которые может обнаружить археолог в степях» [49, с. 42].

В историческом контексте вторая стадия кочевания - это гунны в Европе, авары, болгары в Хазарском каганате, половцы в восточноевропейских степях, кимаки. Поскольку вторая стадия кочевания наиболее характерна для кочевых обществ, она сохраняется очень долго, практически до XX в.: ногайцы, казахи, монголы [49, с. 71].

Третьей стадии кочевания (а это уже фактически оседлость) посвящен пространный дискурс, составляющий более четверти объема рассматриваемого исследования С.А. Плетневой. В отличие от первых двух стадий, от третьей стадии, как считала автор, «сохраняется в земле громадное количество разнообразных памятников, позволяющих осветить все стороны экономической и культурной жизни государства. Это прежде всего остатки обширных поселений, характеризующихся ярко выраженным культурным слоем, насыщенным обломками костей животных и керамики» [49, с. 81]. Переход к третьей стадии исследователь прослеживает практически у всех средневековых кочевников

\footnotetext{
${ }^{6}$ Выделено Г.Е. Марковым.
} 
Евразии, но окончательную ее победу она фиксирует только для Хазарского Каганата и Золотой Орды. И то и в Каганате, и в Золотой Орде «завоеватели так и оставались кочевниками. Они не оседали на землю, т.е. не приобщались к земледельческому труду (за редким исключением)» [49, с. 121].

Характерно также и то, что, как считала С.А. Плетнева, в Золотой Орде, несмотря на господство урбанистической культуры, сохранялись районы, население которых так и осталось на второй стадии кочевания. Именно на этих территориях после распада Золотой Орды сложились кочевые ханства: Сибирское, Астраханское, Ногайская Орда [49, с. 140].

Высокий научный авторитет С.А. Плетневой, непререкаемость (в те времена) ее суждений и четкость предложенной ею концепции в немалой степени способствовали тому, что вскоре появились и другие работы, в которых

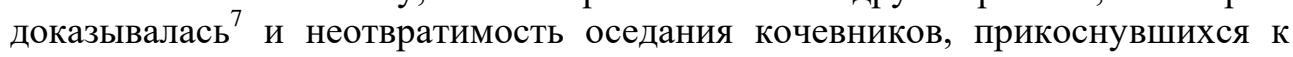
городской цивилизации [2], и целесообразность и закономерность перехода кочевников к оседло-земледельческой жизни [53], и иллюстрировалась последовательность прохождения кочевниками всех трех стадий [20].

Итак, через труды исследователей советского периода «красной нитью» проходит идея о том, что третья стадия кочевания (переход к оседлости) везде была, но нигде не победила.

Аналогичных взглядов на природу и характер номадизма придерживались в то время и зарубежные исследователи. В частности, Е. Бекон, оперируя результатами этнографических наблюдений ученых-путешественников XIX начала XX вв. - Левшина, Радлова, Лансделла, С.И. Руденко и др. - выделила такие характерные черты центрально-азиатского номадизма как стабильные маршруты летних перекочевок, стационарные зимники с землянками и глинобитными хижинами, посевы проса. Однако это не помешало ей сделать общий вывод о том, что киргизы и казахи - нация кочевая, переход к земледелию никогда у них не был массовым, поскольку расценивался как «жизненный упадок», вызванный обстоятельствами или административным принуждением, который они старались превозмочь при первой же возможности [66].

В постсоветское время, когда отечественная историческая наука освободилась от формационных догматов, а в историографии расширился доступ к зарубежным публикациям, в понимании номадизма как исторического явления преобладающим становится т.н. цивилизационный подход, суть которого исследователями раскрывается неоднозначно. Нюансы этой неоднозначности показаны Н.Н. Крадиным, который сам возражает против определения номадизма как цивилизации и предлагает считать «степной мир не как особую цивилизацию, а как “квазицивилизацию”, т.е. некое внешне похожее на цивилизацию единство, которое на самом деле представляется концептуальным конструктом, созданным в мыслях исследователя» (выделено мной aвm.) [25, с. 92].

Что же касается интересующей нас проблемы седентаризации, то она рассматривается в форме дискурсов, зачастую взаимоисключающих.

Например, в рамках цивилизационного подхода Э.С. Кульпиным был поставлен вопрос о цивилизации Золотой Орды, основным признаком которой исследователь называет способность общества «не просто хозяйственно ос-

${ }^{7}$ В том числе и со ссылками на классиков марксизма. 
вочть неблагоприятные для жизни людей участки земной поверхности, но и обеспечить там условия жизни, соответствующие принятым обществом стандартам. В Золотой Орде это обеспечивалось созданием в степи системы городов» [29, с. 182].

Правомерность подобной номинации Н.Н. Крадин подвергает сомнению [25, с. 93].

Впрочем, в контексте интересующего нас вопроса - седентаризация Э.С. Кульпин в рассматриваемой работе затрагивает его в традиционной для советской историографии форме: «Ясно, что первый вариант (массово сесть на землю) не имеет отношения к реальной истории Золотой Орды. Свидетельств о массовых насильственных обращениях кочевников в земледельцев в истории Золотой Орды мы не знаем. Какая-то часть потомков завоевателей кочевников стала горожанами, живущими в городах постоянно. Но большая их часть жила в городах лишь зимой, а с наступлением весны уходила кочевать в окружающие степи. Зимой население степных городов возрастало за счет юрт кочевников, образующих кварталы временного поселения. Повидимому, в случае Золотой Орды речь может идти о втором или, скорее, о третьем варианте - создании нового этноса в степи» [29, с. 180].

Однако в последующих дискурсах Э.С. Кульпина-Губайдуллина происходит эволюция его взглядов на проблему седентаризации кочевников Золотой Орды в сторону ее неизбежности. Автор начинает считать, что вслед за кочевой знатью, которая, по мере появления поселков на территории Золотой Орды, начинает строить в них свои усадьбы и массово переходит к полукочевому или полностью оседлому образу жизни, и их челядь, глядя на них, «начинает приживаться в этих поселках, сливаясь со старожилами мест». А в пятом и шестом (?) поколениях потомки завоевателей восточноевропейских степей уже массово переходят от кочевой к оседлой жизни. Причем, в силу того, что природные условия степи не позволяли кочевникам стать пашенными земледельцами, они в процессе своей седентаризации «перепрыгнули» через земледельческий этап сразу в этап ремесленного городского производства [32, с. 456].

Процесс этот, по мнению исследователя, облегчался тем, что постепенное оседание кочевников (тюрков) на землю «к моменту создания Золотой Орды уже насчитывал несколько столетий» $[30, \text { с. 55 }]^{8}$.

Данный тезис Э.С. Кульпина-Губайдуллина по сути имеет абстрактный характер, поскольку в нем абсолютно не прослеживается ни характер «кочевнического земледелия», ни его значение для хозяйства кочевников. А как уже давние, так и новейшие историко-этнографические исследования показывают, что земледелие кочевников было, во-первых, технологически примитивным, следовательно - малопродуктивным ${ }^{9}$ [68], во-вторых, в домонгольское время в степях Восточной Европы им занимались группы оседлого населения, подвластные кыпчакам/половцам [48].

Что же касается Золотой Орды, то характеристика земледелия, как отрасли хозяйства в этом государстве, современными исследователями дается опять-таки по материалам поселений тех земледельческих районов, которые

\footnotetext{
8 Здесь взгляды исследователя совпадают с позицией советских историков, о чем будет подробнее сказано ниже.

${ }_{9}^{9}$ А это - на примере казахов XIX - начала XX вв.
} 
вошли в состав Золотой Орды - Булгар, Хорезм, Крым и Северный Кавказ $[43 ; 44$, с. $156-172]$.

Свою концепцию неизбежности седентаризации кочевников Золотой Орды («неизбежность перерождения») Э.С. Кульпин-Губайдуллин обосновывает с помощью социально-исторического дискурса, основное содержание которого изложено в виде социолого-философских тезисов, типа: «Бремя империи требовало от завоевателей-кочевников, если не полностью, то в значительной степени превратиться в оседлое население - горожан-ремесленников и земледельцев, либо организовать земледелие и ремесленное производство из других народов, либо выбрать компромиссный вариант, и тогда в степи возник бы новый этнос, в создание которого вложили бы свою лепту все народы империи». Монгольская знать после завоевания степей Восточной Европы подпадает под зависимость от покоренных тюркских кочевников (кыпчаков/половцев), которые должны были пасти скот и обеспечивать благосостояние своих новых господ. Последние, беря себе в жены тюркских женщин, уже в третьем поколении утрачивали свою монгольскую этничность и превращались в тюрков: «Именно с третьего поколения основным языком общения и основной культурой становятся тюркский язык и тюркская культура. Монгольское культурное влияние все более находит свое выражение во второстепенных элементах культуры: отдельных видах и деталях одежды, в прическах, разных элементах ритуала, но видимо более всего, во все времена таким консервативном, как похоронный». Знать Улуса Джучи, добившись независимости от Каракорума, стремительно богатеет и у нее возникает потребность реализовать свой капитал через приобщение к городской культуре: «следовательно, элита была обречена сменить традиционный кочевой образ жизни на городской. Разумеется, эта метаморфоза была постепенной и могла осуществиться лишь с возникновением единства интересов государства и общества» [31, с. 54-57].

В принципе, предложенная Э.С. Кульпин-Губайдуллиным историко-социологическая схема продолжает схему П. Голдена, с той только разницей, что американский ученый считает, что процесс интеграции кочевой элиты в городскую культуру заканчивался драматически для кочевых сообществ. Перенимая культуру и образ жизни завоеванных оседлых обществ, кочевая знать отрывалась от своих рядовых соплеменников, поскольку те не видели для себя никаких преимуществ в седентаризации. Да и сама кочевая знать, не будучи искушенной в государственном управлении аграрными государствами, передавала административные функции либо местной бюрократии, либо тем иноплеменникам, которые были лояльны к завоевателям [67, p. 10-11].

Аналогичную картину реконструируют исследователи, изучающие историю кочевых империй востока Степной Евразии - хунну и тюрков. Там, по их мнению, урбанистическая культура насаждалась группами оседлого населения, депортированными в степь и этнически чуждыми завоевателям [26, c. $331-333 ; 27$, с. $226-227]$.

Альтернативной точки зрения на седентаризацию, ее возможность и целесообразность, придерживается А.М. Хазанов. Для осуществления этого процесса в кочевой среде, по мнению исследователя, необходимо не просто наличие, а доминирование таких факторов, как миграция на новые территории, где кочевое скотоводство было экономически невыгодным по причине 
местных экологических условий (подобные миграции являлись, как правило, вынужденными). Кроме того - ломка психологических стереотипов, поскольку «полная и массовая седентаризация, какими бы путями она не осуществлялась, преодолевает односторонность номадизма тем, что отказывается от него самого» [60, с. 324-328]. И поэтому вполне естественной представляется ситуация, когда кочевники после вынужденной миграции, и даже став вассалами оседло-земледельческого государства, старались сохранить свои культурно-бытовые традиции и образ жизни и даже отстаивали их с оружием в руках перед своим сюзереном: печенеги в Первом Болгарском царстве, кыпчаки/куманы/половцы в Венгерском королевстве XIII-XIV вв. [69; 70; 73].

Иначе говоря, «...именно кочевники являлись их (кочевых империй aвm.) создателями, а социальная стратификация в них в известной мере совпадала с экономической специализацией и этническими различиями. Династии и значительная часть правящих элит в них также были кочевого происхождения. Более того, вопреки достаточно распространенному мнению, большинство рядовых кочевников в таких государствах отнюдь не оседали, а продолжали вести традиционный образ жизни (выделено мною авт.)» [61, с. 14].

Определенные изменения происходят и во взглядах исследователей, ранее придерживавшихся концепции С.А. Плетневой. В частности, К.М. Байпаков теперь уже считает, что «важное значение для понимания взаимоотношений кочевников и земледельцев имеет установленный факт о том, что “чистые кочевники" являлись редким исключением и что элементы оседлости и земледелия всегда сопровождали кочевое хозяйство; в рамках единой этнической общности наряду с кочевым существовали полукочевые и полуоседлые группы скотоводов. Поэтому “непроходимой границы” между земледельцами и скотоводами не было, и в массе последних всегда имелись потенциальные группы населения, которое при определенных условиях и стечении обстоятельств переходили на оседлый образ жизни. Были и обратные процессы (выделено мной - авт.)» [3, с. 345].

Вообще, говоря о седентаризации, прежде всего возникает вопрос об источниках, этот процесс подтверждающих и иллюстрирующих. Естественно, что для нового и новейшего периодов это этнографические данные, для эпохи средневековья - археологические материалы и соответствующие нарративы. Что же представляют из себя археологические источники?

В фундаментальном (и пока самом новом) исследовании по истории Золотой Орды и ее места и роли в мировой истории казахский историк К. Ускенбай, излагая историю левого крыла Улуса Джучи в XIII - начале $\mathrm{XV}$ вв. (Улус Орды, включавший в себя степи Восточного, часть Южного и часть Западного Казахстана до р. Яик), пишет, что «современные археологические исследования говорят о достаточной распространенности традиций земледелия в среде кочевой степи. По руслам крупных рек Иртыш, Чу, СырДарья, Сарысу, Нура, Есиль, Торгай, Тобол, Иргиз, Эмба и Яик население имело постоянные оседлые поселения, которые круглый год не покидались жителями (выделено мной - aвm.)» [55, с. 214-215].

Одновременно А.А. Бисембаев и Г.А. Ахатов на территории Западного Казахстана выделяют несколько районов «сосредоточения оседлой культуры 
золотоордынского времени» - бассейн среднего и нижнего течения Урала, Большого и Малого Узеней, Уило-Кобдинский бассейн [5].

У нас нет оснований сомневаться в том, что подобные районы, маркированные городищами Сарайчик, Жайык на р. Урал, Жалпактал на Узенях, существовали. Другое дело, что из опубликованных данных невозможно понять, какова была роль и степень участия собственно кочевников в сложении этих оседлых центров. Дело в том, что ни в окрестностях Сарайчика, ни в окрестностях Жайыка сколь-нибудь крупных кочевнических могильников пока не обнаружено $^{10}$. Единственная более-менее прослеживаемая географическая связка - это городище Жалпактал и скопление курганов и курганных могильников в низовьях Узеней - Джангала (Новая Казанка), озеро Раим, Джангала (Сарайдин), Джангала (Кара-Оба), Мокринский. Сред них Мокринский могильник наиболее крупный (более 50 захоронений) ${ }^{11}$. Но, во-первых, между перечисленными памятниками и ближайшим к ним городищем Жалпактал по прямой более 80 км. То есть, связывать их в единый археологический комплекс нельзя. Во-вторых, исследователи считают, что Мокринский могильник (и аналогичный ему могильник Маячный бугор I на Нижней Волге, являвшийся городским некрополем Красноярского городища) оставлены отнюдь не кочевниками, а оседлым населением, мигрантами с востока, оказавшимися здесь вследствие административной политики золотоордынских ханов [38; 24].

Аналогичным образом и другие из известных бескурганных могильников Золотой Орды (a priori оставленные оседлым населением) также являются или не кочевническими (аланы - Новохарьковский на Среднем Дону), или оставлены смешанным населением (кочевники и мордва - Аткарский могильник в Среднем Поволжье) [45, с. 176; 17, с. 379; 11, с. 86-94].

А что касается упомянутых К. Ускенбаем поселений по рекам Иртыш, Чу, Сарысу, Нура, Есиль, Торгай, Тобол, Иргиз, Эмба и Яик, то пока приходится констатировать, что по известным данным поселений золотоордынского времени, которые можно было бы связать с кочевниками, здесь нет ${ }^{12}$. Да и вообще, на картах степного Предуралья Российской империи середины XIX в. - «Карта Киргизских степей» и «Карта Оренбургского, Уральского и Башкирского казачьих войск» - также нет обозначений стационарных казахских аулов, хотя обозначены такие реально существовавшие объекты как ханская ставка в северной части Рын-Песков, становище султана правителя Средней Орды в устье р. Хобда, «летние лагери киргизов» в устье р. Эмба, «развалины каменной мечети Берту» в низовьях этой же реки.

Впрочем, даже если подобные поселения будут когда-нибудь исследованы, то едва ли они будут представлять собой нечто более капитальное, нежели казахские зимники XIX - начала XX вв., следы которых в виде оплывших земляночных впадин известны по правобережью р. Урал в Оренбургской области.

Средневековых кочевнических поселений в степях Восточной Европы мы не знаем. Пресловутые половецкие «города» - Шарукань, Сугров и Балин, а

${ }^{10}$ Про территории, перечисленные К. Ускенбаем, я вообще не говорю.

${ }^{11}$ По данным на 2010 год.

${ }^{12}$ По берегам этих рек в 1980-1986 гг. проходили маршруты наших археологических экспедиций. Найдено и исследовано много курганов и несколько мавзолеев XIII-XV вв. и ни одного поселения, относящегося к указанному периоду. 
также Саксин в низовьях Волги - всем известны по упоминаниям в средневековых нарративах и никому - как археологические памятники. Половецкоогузский могильник у Саркела-Белой Вежи, часть погребений которого была впущена в насыпь вала, защищавшего крепость с юга [50, с. 5], к Саркельской крепости может отношения вообе не иметь. Тем более, как показывает Ф.С. Флёров, ни Саркел-Белая Вежа, ни другие «города» Хазарского каганата таковыми не являлись, а были укрепленными лагерями, ханскими аулами. Такими же аулами, по мнению исследователя, были и Плиска и Преслав в Болгарском царстве, где также обитали печенеги [57, с. 39, 42, 178-190; 21, с. 36-37].

Вообще следует отметить, что даже на тех территориях, куда кочевники перемещались в силу экстремальных для них обстоятельств, они продолжали придерживаться своего традиционного образа жизни. Например, печенеги, буквально рассыпавшиеся по территории Первого Болгарского царства, своих поселений не строили, а для сезонного проживания не гнушались использовать заброшенные или оставленные поселения местных насельников [21, с. 40]. Об их вполне индифферентном отношении к руинам более ранних поселений свидетельствует печенежский могильник Одърци, устроенный на развалинах крепости позднеантичного времени [15, с. 7], кочевнические погребения на территории Охлебининского городища в среднем течении р. Белой [19], кочевнические погребения на городище Бозок ${ }^{13}$ в Казахстане [1; 59].

Традиционно археологическим индикатором перехода кочевников к оседлости считается наличие кочевнической керамики в культурных слоях поселений. Кроме Тмутаракани и Саркела-Белой Вежи, она найдена на поселениях Волжской Болгарии (керамика IX и XIII групп - по Т.А. Хлебниковой и Н.А. Кокориной). Ее связывают с памятниками Южного Казахстана и Киргизии и отождествляют «с исторически известными гузами-куманами» Обе эти группы керамики, по мнению названных авторов, генетически связаны. Только на памятниках домонгольского времени (Алексеевское городище, МалоПальцинское селище) они встречены в незначительном количестве (IX группа), хотя в период Золотой Орды керамика XIII группы занимает заметное место в общем керамическом комплексе поселений (от $2 \%$ на Алексеевском поселении до $65 \%$ на городище Джукетау $)^{14}$ [62, с. 116, 227; 23, с. 33]. Каким кочевникам она принадлежит, сказать, конечно, невозможно, поскольку в погребениях печенегов, огузов, кыпчаков/половцев как домонгольского, так и золотоордынского периодов керамические сосуды встречаются крайне редко ${ }^{15}$.

Точно так же керамикой маркируются печенежские поселения на территории Дунайской Болгарии. По форме это горшки и глиняные котлы в виде двойного усеченного конуса или в виде цилиндра с внутренними ушками [21, c. 37]. К подобным же маркёрам исследователи относят находки на поселениях отдельных экземпляров украшений и деталей убранства конской узды [33].

То есть, археологические признаки седентаризации позволяют только говорить о том, что кочевники на том или ином поселении жили, но как долго и как много их было - этот вопрос остается без ответа.

${ }^{13}$ Бывшем древнетюркском святилище [58].

${ }^{14}$ Следует иметь в виду, что удельный вес керамических групп высчитывается не от всей керамики поселений, а от небулгарской ее части.

${ }^{15}$ В погребениях огузо-печенежского времени - $11,3 \%$; у половцев - 9,6\%; у кочевников Золотой Орды - $1 \%$. 
Еще одним признаком инфильтрации кочевников в городскую среду исследователи считают расположение кочевнических могильников вблизи золотоордынских городов [6, с. 92-97]. О неочевидности этого признака мне уже приходилось писать [18].

Основным источником информации о формах и типах кочевнического бытия являются нарративы. Не буду здесь приводить избыточно известные сведения средневековых европейских (Гийом де Рубрук) и арабо-персидских (Ибн-Василь, Ал-Омари, Ибн Шохба ал-Асади, Ибн Арабшах, Ибн Баттута) авторов, описывавших кочевнический быт, нравы, внешний вид обитателей золотоордынской степи. Остановлюсь на свидетельствах более поздних авторов, описывавших кочевников уже после Золотой Орды по своим собственным наблюдениям. Они не занимались целенаправленным сбором этнографических данных, поэтому их спонтанные сведения являются точными.

В описаниях путешественников XV-XVII вв. кочевники Восточной Европы - ногаи, башкиры, казахи - находились на полукочевой (второй - по С.А. Плетневой) стадии своего бытия. Они имели определенные территории и маршруты кочевания, практиковали земледелие (выращивали просо), имели зимники по берегам рек $[4, \S \S 16-31 ; 13$, с. $141-145,159 ; 22$, с. 95, 139-140; 63, c. $31 ; 46$, с. 405]. Хотя ментальность их оставалась исключительно номадической, о чем весьма ярко сообщает нам С. Герберштейн: «Они никогда не остаются в течение долгого отрезка времени в одном месте, поскольку они считают это большим бедствием для себя. Поэтому, когда они сердятся на своих детей и хотят напугать их тяжелым проклятием, они обычно говорят: чтоб вы сидели на одном месте, как христианин, и дышали собственной вонью! Так что, когда они поедают пастбище, которое они могут найти в одном месте, они мигрируют в другое место вместе со своим скотом, женами и детьми, которых они всегда ведут с собой в болотистых местах» [13, с. 143-144].

В трудах ученых-путешественников XVIII-XIX вв. представлены сведения (в т.ч. собранные и с этнографическими целями) о кочевых народах, находившихся в составе Российской империи - башкирах, казахах («киргизкайсаках»), калмыках. Здесь мы также наблюдаем картину полукочевого образа жизни: выезд на летние пастбища, зимовка в аулах, небрежение земледелием $[36$, с. $37 ; 47$, с. $8-9 ; 12$, с. $31-35,136 ; 34$, с. $163-165 ; 35$, с. 295-298; 41, с. $167 ; 7$, с. $10 ; 51$, с. 253-258]. В частности, И. Лепехин, описывая наблюдаемый им в 1770 г. у башкир праздник сабантуй, отмечал: «хотя Башкирцы еще по сие время очень худые и ленивые хлебопашцы; однако по соседству с Русскими и с ясашных Татар селениями начинают вникать в хлебопашество; и всякий старается по крайней мере столько посеять хлеба, сколько для домашнего обихода потребно. Они наиболее сеют ячмень и овес; а зимовой хлеб для них за ненужной почитается» [36, с. 24].

С.И. Руденко, приводя эти сведения в качестве доказательства наличия у башкир земледелия, тем не менее, отмечал: «в конце XIX - начале XX в. при оседлом образе жизни значительная часть башкир (выделено мной - авт.) летом еще выезжала на кочевки. Это были преимущественно зауральские башкиры: катайцы и айлинцы, кара-барын-табынцы и куваканцы, тамьянтабынцы, бурзяне; в горной части Башкирии: корные катайцы и кипчаки; в бассейне р. Белой: табынцы и юрматынцы; в бассейнах рек Демы и Б. Ур- 
шака: южные минцы; на юге: кипчаки, тамьян-табынцы и северные: усергане» $[52$, с. 59].

Как вполне продуктивное, исследователи XIX в. характеризовали занятие земледелием у казахов Большой Орды и кара-киргизов (бугу) Прииссыккулья. Но у первых оно появилось поздно, в начале XVII в., под влиянием китайцев и узбеков [9, с. 184-188; 8, с. 107], а у вторых оно являлось дополнительным к скотоводству промыслом, которым занимались люди, специально для этого нанятые богатыми скотоводами [51, с. 295, 348-349].

Современные исследователи ${ }^{16}$ имели и имеют дело с кочевниками, уже подвергшимися процессу седентаризации, как правило - принудительной. Однако в своих историко-этнографических изысканиях они отмечают, что к началу XX в. казахи продолжали оставться кочевниками и удельный вес городского и оседлого населения среди них был чуть более $1 \%$ [39, с. 55; 54, с. 19]. Сохранялась традиционная форма ведения кочевого хозяйства - сезонные перекочевки по маршруту зимник (кышлак) - летнее кочевье (йайляу/джяйляу) и обратно.

Однако Советская власть, повсеместно победившая на территории бывшей Российской империи, была заинтересована в установлении политического, идеологического и административного контроля над традиционными кочевыми обществами. Поэтому уже в конце 1920-х гг. она начинает политику принудительной седентаризации кочевников [54, с. 33-45].

Аналогичные процессы имели место и в Монголии. В XV в. прекращается монгольское градостроительство, поскольку монгольские города, в отличие от городов Золотой Орды, имевших свою сельскохозяйственную округу [43], сильно зависели от подвоза продовольствия из Китая, который в это время уже начинает освобождаться от монгольского владычества [16, с. 524]. В 1920-е годы там также и под влиянием схожих социально-политических факторов происходит процесс насильственной седентаризации кочевников. Что, впрочем, успехом не увенчалось: при первой же возможности монголы старались освободиться от этого неприемлемого для них образа жизни [71]. А что касается урбанизации, то она в социалистической Монголии приобретала причудливые (если не сказать - гротескные) формы: по свидетельствам очевидцев, столица страны - Улан-батор - в 70-е годы прошлого столетия представляла собой типовые панельные здания, плотно окруженные скоплением традиционных юрт [64, с. 487-494].

${ }^{16}$ Имея в виду и исследователей второй половины XX столетия. 
Все выше сказанное позволяет нам сделать следующие выводы:

- Седентаризация отнюдь не являлась самоцелью кочевых сообществ. Там, где она осуществлялась правящей верхушкой, происходил раскол общества и «ордынская замятня» 60-x - 80-х годов XIV в. - наглядная тому иллюстрация;

- Непрерывное кочевание (первая - таборная - стадия кочевания) - ничто иное, как миграция кочевников в поисках новых мест обитания, вызванная экстремальными условиями бытия на прежнем месте (перенаселение, ухудшение климата, давление извне);

- Вторая стадия кочевания по схеме кышлак - йайляу - кышлак является наиболее характерной (единственной) формой существования кочевых сообществ;

- «Третья стадия кочевания» - это уже оседлость, к которой кочевников принуждали насильственно.

В заключение можно привести высказывания двух исследователей центрально-азиатского номадизма, всецело, на мой взгляд, отражающих его сущность как исторического явления:

Н.Э. Масанов: «процессы седентаризащии в ареальных эко-системах принципиально невозможны в аграрном обществе 17 и никогда в исторически обозримое время не имели места. Поэтому следует отказаться от мысли, что эволюционное развитие номадизма завершается оседанием. Процессы седентаризации могли иметь место только за пределами ареальных экосистем - в маргинальных зонах либо в оседло-земледельческих ареалах. В ареалах номадизма оседание никогда не имело природной и материальной базы и даже в условиях индустриального общества нет альтернативы кочевничеству как наиболее рациональной стратегии природопользования. В своем историческом развитии номадизм постепенно умирает как способ производства, поскольку не может быть полностью адаптирован к условиям индустриального и урбанизированного общества» [39, с. 42].

Д. Филлипс: «Кочевничество формирует способность адаптироваться к изменяющимся возможностям, создаваемым новыми ресурсами и рынками. Кочевые скотоводы могут вносить значительные изменения в свой образ жизни, чтобы сохранить свое общество и культуру. Кочевники обладают опытом своих предков приспосабливаться к различным жизненным условиям, для которых номадизм является не только идеальным, но и реальным стилем жизни. Это может повлечь за собой изменение территории обитания, видов скота или способа расселения для того, чтобы сохранить то, что считается наиболее важным для их идентичности» [71, p. 30].

\section{СПИСОК ЛИТЕРАТУРЫ}

1. Акишев К.А., Хабдулина М.К. Результаты пятилетних раскопок городища Бозок // Бозок в панораме средневековых культур Евразии. Материалы Международного полевого семинара (29-30 июля 2004 г.). Астана: Евразийский национальный университет им. Л.Н. Гумилёва, 2008. С. 25-40.

\footnotetext{
${ }^{17}$ Выделено Н.Э. Масановым.
} 
2. Байпаков К.M. Город и степь в эпоху средневековья (по материалам Южного Казахстана и Семиречья) // Взаимодействие кочевых культур и древних цивилизаций. Алма-Ата: Наука, 1989. С. 336-345.

3. Байпаков К.M. Древняя и средневековая урбанизация Казахстана (по материалам исследований Южно-Казахстанской комплексной археологической экспедиции), Книга I: Урбанизация Казахстана в эпоху бронзы - раннем средневековье. Алматы, 2012. $390 \mathrm{c.}$

4. Барбаро и Контарини о России. М.: Наука. 1971.

5. Бисембаев А.А., Ахатов Г.А. Городища эпохи Золотой Орды на территории Западного Казахстана // «Диалог городской и степной культур на Евразийском пространстве. Историческая география Золотой Орды». Материалы Седьмой Международной конференции, посвящённой памяти Г.А. Фёдорова-Давыдова. Казань; Ялта; Кишинёв, 2016. С. 74-76.

6. Блохин В.Г., Яворская Л.В. Археология золотоордынских городов Нижнего Поволжья. Волгоград: Издательство Волгоградского государственного университета, 2006. $268 \mathrm{c}$.

7. Валиханов Ч.Ч. Записки о киргизах // Собрание сочинений в пяти томах. Алма-Ата: Главная редакция Казахской советской энциклопедии, 1985. Т. 2. С. 7-71.

8. Валиханов Ч.Ч. О кочевках киргиз // Собрание сочинений в пяти томах. Алма-Ата: Главная редакция Казахской советской энциклопедии, 1985. Т. 4. С. 105-110.

9. Валиханов Ч.Ч. О хлебопашестве // Собрание сочинений в пяти томах. АлмаАта: Главная редакция Казахской советской энциклопедии, 1984. Т. 1. С. 184-190.

10. Вернадский Г.В. Монголы и Русь. Тверь: ЛЕАН; М.: АГРАФ, 1999. 480 с.

11. Гарустович Г.Н., Ракушин А.И., Яминов А.Ф. Средневековые кочевники Поволжья (конца IX - начала XV века). Уфа: Гилем, 1998. 336 с.

12. Георги И.Г. Описание всех в Российском государстве обитающих народов, так же их житейских обрядов, вер, обыкновений, жилищ, одежд и прочих достопамятностей, Ч. 2: О народах татарского племени. СПб., 1776. 188 с.

13. Герберштейн С. Записки о московитских делах / Малеин А.И. (пер.). СПб., $1908.382 \mathrm{c}$.

14. Голубовский П.В. Печенеги, торки и половцы. Русь и Степь до нашествия татар. М.: Вече, 2011. 288 c.

15. Дончева-Петкова Л. Одърци. Некрополи от ХІ век. София, 2005. Т. 2. 465 с.

16. Дробышев Ю.И. Человек и природа в кочевых обществах Центральной Азии (III в. до н.э. - XVI в. н.э.) / Васильев Д.Д. (ред.). М.: Институт востоковедения Российской академии наук, 2014. 608 с.

17. Зеленеев Ю.А. Расселение мордвы: её этническая и политическая история в XIII-XV вв. // Генуэзская Газария и Золотая Орда = The Genoese Gazaria and the Golden Horde. Кишинев: Stratum Plus, 2015. С. 377-382.

18. Иванов B.A. Город и степь Улуса Джучи (Золотой Орды) - историческая антитеза // Золотоордынская цивилизация. 2017. № 10. С. 162-167.

19. Иванов В.А. Погребения средневековых кочевников на территории Охлебининского городища // Советская археология. 1977. № 1. С. 292-295.

20. Иванов B.A. Три стадии кочевания в истории средневековых племен УралоПоволжских степей // Новое в средневековой археологии Евразии. Самара, 1993. C. $95-101$.

21. Йотов В. Българските земи и нашествията на късните номади в края на XIXII в. Автореферат на дисертация за присъждане на образователна и научна степен „Доктор“. София, 2015. 50 с.

22. Книга большому чертежу. М.; Л., 1950. 228 с.

23. Кокорина Н.A. Керамика Волжской Булгарии второй половины ХІ - начала XV в. Казань: Институт истории АН РТ, 2002. 383 с. 
24. Комаров С.Г., Китов Е.П. Население Волго-Уральского междуречья в эпоху Золотой Орды (по материалам из могильника Мокринский I) // Вестник археологии, антропологии и этнографии. 2014. № 2 (25). С. 80-88.

25. Крадин Н.Н. Кочевничество и теория цивилизаций // Крадин Н.Н. Кочевники Евразии. Алматы: «Дайк-Пресс», 2007. С. 86-94.

26. Крадин Н.Н. Урбанизационные процессы в кочевых империях монгольских степей // Монгольская империя и кочевой мир (Материалы международной научной конференции). Улан-Удэ: Издательство Бурятского научного центра Сибирского отделения Российской академии наук, 2008. Кн. 3. С. 330-346.

27. Крадин Н.Н., Ивлиев А.Л., Васютин С.А. Империя хунну и начала степной урбанизации // Тюркские кочевники в Азии и Европе: цивилизационные аспекты истории и культуры. 2018. С. 226-240.

28. Кротков Е. Научный дискурс // Современный дискурс-анализ. Электронный журнал. 2010. Вып. 2. Т. 1. С. 4-18.

29. Кульпин Э.С. Цивилизация Золотой Орды // Монгольская империя и кочевой мир. Улан-Удэ: Издательство Бурятского научного центра Сибирского отделения Российской академии наук, 2004. С. 167-186.

30. Кульпин-Губайдуллин Э.С. Золотая Орда: Проблемы генезиса Российского государства. М.: Книжный дом «ЛИБРОКОМ», 2009. 176 с.

31. Кульпин-Губайдуллин Э.С. Золотая Орда: Судьбы поколений. М.: Книжный дом «ЛИБРОКОМ», 2011. $192 \mathrm{c}$.

32. Кульпин-Губайдуллин Э.С. Экологические и экономические критерии цивилизованности Золотой Орды // Золотая Орда в мировой истории. Коллективная монография. Казань: Институт истории им. Ш.Марджани АН РТ, 2016. С. 447-456.

33. Курта Ф. Образ и археология печенегов // Stratum plus, № 5: Под знаком Рюриковичей. 2013. С. 203-231.

34. Левекк Ш.-П. История народов, подвластных России. Сахибгареева Л.Ф. (пер.), И.В. Кучумов (ред.). СПб.: «Дмитрий Буланин», 2016. 480 с.

35. Левшин А.И. Описание киргиз-казачьих, или киргиз-кайсацких, орд и степей. Алматы: «Санат», 1996. 656 с.

36. Лепехин И. Продолжение дневных записок путешествия академика и медицины доктора Ивана Лепехина по разным провинциям Российского государства в 1770 году. СПб., 1772. 338 с.

37. Марков Г.Е. Кочевники Азии: Структура хозяйства и общественной организации. 2-е изд. М.: КРАСАНД, 2010. 320 с.

38. Марыксин Д.В. Археологический комплекс времен Золотой Орды Мокринский I // Археология Нижнего Поволжья: проблемы, поиски, открытия: материалы III Международной Нижневолжской археологической конференции (Астрахань, 1821 октября 2010 г.). Астрахань: Астраханский государственный университет, Издательский дом «Астраханский университет», 2010. С. 312-317.

39. Масанов Н.Э. Кочевая цивилизация казахов: основы жизнедеятельности номадного общества. Алматы: «Социнвест»; Москва: «Горизонт», 1995. 320 с.

40. Миньяр-Белоручева А.П. Типология исторического дискурса // Язык и текст. 2015. T. 2. № 2. С. 8-16. DOI:10.17759/langt.2015020202

41. Небольсин П. Очерки Волжского Низовья. СПб., 1852. 197 с.

42. Небольсин П. Очерки быта калмыков Хошоутовскаго улуса. СПб., 1852. $190 \mathrm{c}$.

43. Недашковский Л.Ф. Земледелие, скотоводство, промыслы и ремесла // Золотая Орда в мировой истории. Коллективная монография. Казань: Институт истории им. Ш.Марджани АН РТ, 2016. С. 551-578.

44. Недашковский Л.Ф. Золотоордынские города Нижнего Поволжья и их округа. М.: Восточная литература, 2010. 351 с. 
45. Новохарьковский могильник эпохи Золотой Орды. Воронеж: Издательство Воронежского государственного университета, 2002. $200 \mathrm{c.}$

46. Олеарий А. Описание путешествия в Московию и через Московию в Персию и обратно. СПб.: Издание А.С. Суворина, 1906. 582 с.

47. Паллас П.-С. Путешествие по разным местам Российского государства, Ч. 2. Кн. 2: 1770 г. СПб., $1786.571 \mathrm{c.}$

48. Пилипчук Я.В. Осілість та землероби у Дашт-і Кипчак // Гілея: науковий вісник. Збірник наукових праць. К., 2012. Вип. 60. Режим доступа: http://shron1. chtyvo.org.ua/Pylypchuk_Yaroslav/Osilist_ta_zemleroby_u_Dasht-i_Kypchak.pdf

49. Плетнева С.А. Кочевники Средневековья. Поиски исторических закономерностей. М.: Наука, 1982. 186 с.

50. Плетнева C.A. Печенеги и огузы на Нижнем Дону. М., 1990. 101 с.

51. Радлов В.В. Из Сибири. Страницы дневника. М.: Наука, Главная редакция восточной литературы, 1989. 749 с.

52. Руденко С.И. Башкиры. Историко-этнографические очерки. Уфа: Китап, 2006. $376 \mathrm{c}$.

53. Савельева T.B. Формирование средневековых городов у кочевников (по материалам раскопок городища Талгар) // Взаимодействие кочевых культур и древних цивилизаций. Алма-Ата: Наука, 1989. С. 432-438.

54. Синицын Ф.Л. Советское государство и кочевники. История, политика, население. 1917-1991. М.: Центрполиграф, 2019. 318 с.

55. Ускенбай K. Левое крыло Улуса Джучи в XIII - начале XV века // Золотая Орда в мировой истории. Коллективная монография. Казань: Институт истории им. Ш. Марджани АН РТ, 2016. С. 208-216.

56. Федоров-Давыдов Г.А. Кочевники Восточной Европы под властью золотоордынских ханов. М.: Издательство Московского университета, 1966. 274 с.

57. Флёров В.С. «Города» и «замки» Хазарского каганата. Археологическая реальность. М.: Мосты культуры/Гешарим, 2011. 264 с.

58. Хабдулина М.К. Древнетюркский культовый центр в Верхнем Прииртышье // Труды IV(XX) Всероссийского археологического центра в Казани. Казань: Отечество, 2014. T. III. C. 545-547.

59. Хабдулина M.К. Золотоордынские погребения некрополя Бозок (Центральный Казахстан) // Древние культуры Северного Китая, Монголии и Байкальской Сибири. Ке хue chu ban she, 2015.

60. Хазанов А.М. Кочевники и внешний мир. 3-е изд. Алматы: Дайк-Пресс, $2002.604 \mathrm{c}$.

61. Хазанов А.М. Кочевые государства и государства кочевников. Тавтология или история? // Феномен кочевничества в истории Евразии. Номадизм и развитие государства: Сборник материалов Международной научной конференции. Алматы: Дайк-Пресс, 2007. С. 9-16.

62. Хлебникова T.А. Керамика памятников Волжской Болгарии. К вопросу об этнокультурном составе населения. М.: Наука, 1984. 240 с.

63. Хождение купца Федота Котова в Персию. М., 1958. 110 с.

64. Черныл E.H. Степной пояс Евразии: Феномен кочевых культур. М.: Рукописные памятники Древней Руси, 2009. 624 с.

65. Энгельс Ф. Происхождение семьи, частной собственности и государства // Сочинения К. Маркса и Ф. Энгельса. 2-е изд. Т. 21. С. 28-178.

66. Bacon E. Types of pastoral nomadism in Central and Southwest Asia // Southwestern Journal of Anthropology. 1954. Vol. 10. P. 44-68.

67. Golden P.B. An Introduction to the History of the Turkic Peoples: Ethnogenesis and State Formation in Medieval and Early Modern Eurasia and the Middle East. Wiesbaden: Harrassowitz, 1992. 483 p. 
68. Krader L. The ecology of nomadic pastoralism // International Social Science Bulletin. 1959. Vol. 11. No. 4. P. 499-510.

69. Lyublyanovics $K$. The Cumans in medieval Hungary and the question of ethnicity // Annual of Medieval Studies at Central European University. Budapest: Central European University, 2011. No. 17. P. 153-169.

70. Pálóczi Horváth A. Keleti népe k a középkori Magyarországon // Besenyők, úzok, kunok és jászok müvelődéstörténeti emlékei. Budapest; Piliscsaba, 2014.

71. Phillips D. Peoples on the Move. Introducing the Nomads of the World. London: William Carey Library, 2001.

72. Sigismund von Herberstein. Rerum Moscoviticarum Commentarii. London, 1852. Vol. II.

73. Spinei $V$. The Romanians and the Turkic Nomads North of the Danube Delta from the tenth to the mid-thirteenth century. Leiden; Boston, 2009. $521 \mathrm{p}$.

Сведения об авторе: Владимир Александрович Иванов - доктор исторических наук, профессор кафедры Отечественной истории Башкирского государственного педагогического университета им. М. Акмуллы (450008, ул. Октябрьской революции, 3A, Уфа, Российская Федерация); ORCID: 0000-0002-7243-2588. E-mail: ivanovsanych@inbox.ru

Поступила 15.03.2021 Принята к публикаџии 02.06.2021

Опубликована 29.06.2021

\section{REFERENCES}

1. Akishev K.A., Khabdulina M.K. Rezul'taty pyatiletnikh raskopok gorodishcha Bozok [Results of five-year excavations of the Bozok settlement]. Bozok v panorame srednevekovykh kul'tur Evrazii. Materialy Mezhdunarodnogo polevogo seminara (29-30 iyulya 2004 g.) [Bozok in the Panorama of the Medieval Cultures of Eurasia. Proceedings of the International Field Workshop (July 29-30, 2004)]. Astana: L.N. Gumilyov Eurasian National University, 2008, pp. 25-40. (In Russian)

2. Baypakov K.M. Gorod i step' v epokhu srednevekov'ya (po materialam Yuzhnogo Kazakhstana i Semirech'ya) [City and steppe in the Middle Ages (based on materials from South Kazakhstan and Semirechye)]. Vzaimodeystvie kochevykh kul'tur $i$ drevnikh tsivilizatsiy [Interaction of Nomadic Cultures and Ancient Civilizations]. Alma-Ata: Nauka, 1989, pp. 336-345. (In Russian)

3. Baypakov K.M. Drevnyaya i srednevekovaya urbanizatsiya Kazakhstana (po materialam issledovaniy Yuzhno-Kazakhstanskoy kompleksnoy arkheologicheskoy ekspeditsii), Kniga I: Urbanizatsiya Kazakhstana v epokhu bronzy - rannem srednevekov'e [Ancient and Medieval Urbanization of Kazakhstan (Based on Research Materials of the South Kazakhstan Integrated Archaeological Expedition), Book I: Urbanization of Kazakhstan in the Bronze Age - Early Middle Ages]. Almaty, 2012. 390 p. (In Russian)

4. Barbaro i Kontarini o Rossii [Barbaro and Contarini about Russia]. Moscow: Nauka, 1971. (In Russian)

5. Bisembaev A.A., Akhatov G.A. Gorodishcha epokhi Zolotoy Ordy na territorii Zapadnogo Kazakhstana [Settlements of the era of the Golden Horde on the territory of Western Kazakhstan]. "Dialog gorodskoy i stepnoy kul'tur na Evraziyskom prostranstve. Istoricheskaya geografiya Zolotoy Ordy”. Materialy Sed'moy Mezhdunarodnoy konferentsii, posvyashchennoy pamyati G.A. Fedorova-Davydova ["Dialogue between Urban and Steppe Cultures in the Eurasian Space. Historical Geography of the Golden Horde". 
Proceedings of the Seventh International Conference Dedicated to the Memory of G.A. Fedorov-Davydov]. Kazan; Yalta; Kishinev, 2016, pp. 74-76. (In Russian)

6. Blokhin V.G., Yavorskaya L.V. Arkheologiya zolotoordynskikh gorodov Nizhnego Povolzh'ya [Archaeology of the Golden Horde Cities of the Lower Volga Region]. Volgograd: Volgograd State University publishing house, 2006. 268 p. (In Russian)

7. Valikhanov Ch.Ch. Zapiski o kirgizakh [Notes about the Kirghiz]. Sobranie sochineniy $v$ pyati tomakh [Collected Works in Five Volumes]. Alma-Ata: Main editorial office of the Kazakh Soviet Encyclopedia, 1985, vol. 2, pp. 7-71. (In Russian)

8. Valikhanov Ch.Ch. O kochevkakh kirgiz [About Kyrgyz migrations]. Sobranie sochineniy $v$ pyati tomakh [Collected Works in Five Volumes]. Alma-Ata: Main editorial office of the Kazakh Soviet Encyclopedia, 1985, vol. 4, pp. 105-110. (In Russian)

9. Valikhanov Ch.Ch. O khlebopashestve [About arable farming]. Sobranie sochineniy $v$ pyati tomakh [Collected Works in Five Volumes]. Alma-Ata: Main editorial office of the Kazakh Soviet Encyclopedia, 1984, vol. 1, pp. 184-190. (In Russian)

10. Vernadskiy G.V. Mongoly $i$ Rus' [The Mongols and Rus']. Tver: LEAN; Moscow: AGRAF, 1999. 480 p. (In Russian)

11. Garustovich G.N., Rakushin A.I., Yaminov A.F. Srednevekovye kochevniki Povolzh'ya (kontsa IX - nachala XV veka) [Medieval Nomads of the Volga Region (from the end of the ninth to beginning of fifteenth century)]. Ufa: Gilem, 1998. 336 p. (In Russian)

12. Georgi I.-G. Opisanie vsekh v Rossiyskom gosudarstve obitayushchikh narodov, tak zhe ikh zhiteyskikh obryadov, ver, obyknoveniy, zhilishch, odezhd $i$ prochikh dostopamyatnostey, Chast' 2: O narodakh tatarskogo plemeni [Description of All the Peoples Living in the Russian State as well as Their Everyday Rituals, Believes, Customs, Dwellings, Clothes, and Other Worthy Mentioning, Part 2: On the Peoples of the Tatar Tribe]. St. Petersburg, 1776. 188 p. (In Russian)

13. Herberstein S. Zapiski o moskovitskikh delakh [Notes on the Muscovite Affairs]. Malein A.I. (tr.). St. Petersburg, 1908. 382 p. (In Russian)

14. Golubovskiy P.V. Pechenegi, torki i polovtsy. Rus' i Step' do nashestviya tatar [The Pechenegs, Torks, and Polovtsians. Rus' and the Steppe before the Invasion of Tatars]. Moscow: Veche, 2011. 288 p. (In Russian)

15. Doncheva-Petkova L. Od"rtsi. Nekropoli ot XI vek [Odartsi. Necropolises from the eleventh century]. Sofia, 2005, vol. 2. 465 p. (In Bulgarian)

16. Drobyshev Yu.I. Chelovek i priroda $v$ kochevykh obshchestvakh Tsentral'noy Azii (III v. do n.e. - XVI v. n.e.) [Man and Nature in the Nomadic Societies of Central Asia (from the third century BC to sixteenth century AD)]. Vasil'ev D.D. (ed.). Moscow: Institute of Oriental Studies of the Russian Academy of Sciences, 2014. 608 p. (In Russian)

17. Zeleneev Yu.A. Rasselenie mordvy: ee etnicheskaya i politicheskaya istoriya $\mathrm{v}$ XIII-XV vv. [The settlement of the Mordovians: Its ethnic and political history from the thirteenth to fifteenth centuries]. Genuezskaya Gazariya i Zolotaya Orda = The Genoese Gazaria and the Golden Horde. Kishinev: Stratum Plus, 2015, pp. 377-382. (In Russian)

18. Ivanov V.A. Gorod i step' Ulusa Dzhuchi (Zolotoy Ordy) - istoricheskaya antiteza [The city and steppe of the Jochid Ulus (Golden Horde): A historical antithesis] Zolotoordynskaya tsivilizatsiya [Golden Horde Civilizaiton]. 2017, no. 10, pp. 162-167. (In Russian)

19. Ivanov V.A. Pogrebeniya srednevekovykh kochevnikov na territorii Okhlebininskogo gorodishcha [Burials of medieval nomads on the territory of the Okhlebininsky settlement]. Sovetskaya arkheologiya [Soviet Archaeology]. 1977, no. 1, pp. 292-295. (In Russian)

20. Ivanov V.A. Tri stadii kochevaniya $\mathrm{v}$ istorii srednevekovykh plemen UraloPovolzhskikh stepey [Three stages of nomadism in the history of medieval tribes of the Ural-Volga steppes]. Novoe v srednevekovoy arkheologii Evrazii [New in Medieval Archaeology of Eurasia]. Samara, 1993, pp. 95-101. (In Russian) 
21. Yotov V. B"lgarskite zemi $i$ nashestviyata na $k$ "snite nomadi v kraya na XI$X I I v$. Avtoreferat na disertatsiya za pris"zhdane na obrazovatelna $i$ nauchna stepen "Doktor" [The Bulgarian Lands and the Invasions of the Late Nomads at the end of eleventh and twelfth century. PhD Thesis]. Sofia, 2015. 50 p. (In Bulgarian)

22. Kniga bol'shomu chertezhu [Big Book of Drawing]. Moscow; Leningrad, 1950. 228 p. (In Russian)

23. Kokorina N.A. Keramika Volzhskoy Bulgarii vtoroy poloviny XI - nachala XV v. [Pottery of the Volga Bulgaria from the second half of eleventh to beginning of fifteenth century] Kazan: Institute of History, 2002. 383 p. (In Russian)

24. Komarov S.G., Kitov E.P. Naselenie Volgo-Ural'skogo mezhdurech'ya v epokhu Zolotoy Ordy (po materialam iz mogil'nika Mokrinskiy I) [Population of the Volga-Ural interfluve in the era of the Golden Horde (based on materials from the Mokrinsky I burial ground)]. Vestnik arkheologii, antropologii i etnografii [Bulletin of Archaeology, Anthropology, and Ethnography]. 2014, no. 2 (25), pp. 80-88. (In Russian)

25. Kradin N.N. Kochevnichestvo i teoriya tsivilizatsiy [Nomadism and the theory of civilizations]. Idem. Kochevniki Evrazii [The Nomads of Eurasia]. Almaty: Dayk-Press, 2007, pp. 86-94. (In Russian)

26. Kradin N.N. Urbanizatsionnye protsessy v kochevykh imperiyakh mongol'skikh stepey [Urbanization processes in the nomadic empires of the Mongolian steppes]. Mongol'skaya imperiya i kochevoy mir (Mat-ly mezhdunar. nauch. konf-ii) [Mongol Empire and the Nomadic World (Proceedings of an international research conference)]. Ulan-Ude: Publishing House of the Buryat Scientific Center of the Siberian Branch of the Russian Academy of Sciences, 2008, part 3, pp. 330-346. (In Russian)

27. Kradin N.N., Ivliev A.L., Vasyutin S.A. Imperiya khunnu i nachala stepnoy urbanizatsii [Xiongnu Empire and the beginning of steppe urbanization]. Tyurkskie kochevniki v Azii i Evrope: tsivilizatsionnye aspekty istorii $i$ kul'tury [Turkic Nomads in Asia and Europe: Civilizational Aspects of History and Culture]. 2018, pp. 226-240. (In Russian)

28. Krotkov E. Nauchnyy diskurs [Scientific discourse]. Sovremennyy diskurs-analiz [Contemporary Discourse Analysis]. 2010, iss. 2, vol. 1, pp. 4-18. (In Russian)

29. Kul'pin E.S. Tsivilizatsiya Zolotoy Ordy [Civilization of the Golden Horde]. Mongol'skaya imperiya i kochevoy mir [The Mongol Empire and the Nomadic World]. Ulan-Ude: Publishing House of the Buryat Scientific Center of the Siberian Branch of the Russian Academy of Sciences, 2004, pp. 167-186. (In Russian)

30. Kul'pin-Gubaydullin E.S. Zolotaya Orda: Problemy genezisa Rossiyskogo gosudarstva [The Golden Horde: Problems of the Genesis of the Russian State]. Moscow: Book house "Librocom", 2009. 176 p. (In Russian)

31. Kul'pin-Gubaydullin E.S. Zolotaya Orda: Sud'by pokoleniy [The Golden Horde: Fates of Generations]. Moscow: Book house "Librocom", 2011. 192 p. (In Russian)

32. Kul'pin-Gubaydullin E.S. Ekologicheskie i ekonomicheskie kriterii tsivilizovannosti Zolotoy Ordy [Environmental and economic criteria for the civilization of the Golden Horde]. Zolotaya Orda v mirovoy istorii. Kollektivnaya monografiya [The Golden Horde in World History. Collective Monograph]. Kazan: Marjani Institute of History of Tatarstan Academy of Sciences, 2016, pp. 447-456. (In Russian)

33. Kurta F. Obraz i arkheologiya pechenegov [The image and archaeology of the Pechenegs]. Stratum plus, no. 5: Pod znakom Ryurikovichey [Stratum plus, No. 5: Under the sign of the Rurikovichi], pp. 203-231. (In Russian)

34. Levesque P.-Ch. Istoriya narodov, podvlastnykh Rossii [Histoire des différents peuples soumis à la domination des Russes]. Sakhibgareeva L.F. (tr.), Kuchumov I.V. (ed.). St. Petersburg: Dmitriy Bulanin, 2016. 480 p. (In Russian)

35. Levshin A.I. Opisanie kirgiz-kazach'ikh, ili kirgiz-kaysatskikh, ord i stepey [Description of the Kyrgyz-Cossack or Kyrgyz-Kaysak Hordes and Steppes]. Almaty: Sanat, 1996. 656 p. (In Russian) 
36. Lepekhin I. Prodolzhenie dnevnykh zapisok puteshestviya akademika i meditsiny doktora Ivana Lepekhina po raznym provintsiyam Rossiyskogo gosudarstva v 1770 godu [Continuation of the Daily Notes of the Journey of the Academician and Doctor of Medicine, Ivan Lepekhin, to Different Provinces of the Russian State in 1770]. St. Petersburg, 1772. 338 p. (In Russian)

37. Markov G.E. Kochevniki Azii: Struktura khozyaystva i obshchestvennoy organizatsii [Nomads of Asia: Structure of the Economy and Social Organization]. Second edition. Moscow: Krasand, 2010. 320 p. (In Russian)

38. Maryksin D.V. Arkheologicheskiy kompleks vremen Zolotoy Ordy Mokrinskiy I [Mokrinsky I archaeological complex of the times of the Golden Horde]. Arkheologiya Nizhnego Povolzh'ya: problemy, poiski, otkrytiya: materialy III Mezhdunarodnoy Nizhnevolzhskoy arkheologicheskoy konferentsii (Astrakhan', 18-21 oktyabrya 2010 g.). [Archaeology of the Lower Volga Region: Problems, Searches, Discoveries: Proceedings of the Third International Lower Volga Archaeological Conference (Astrakhan, 18-21 October 2010)] Astrakhan: Astrakhan State University, "Astrakhan University" publishing house, 2010, pp. 312-317. (In Russian)

39. Masanov N.E. Kochevaya tsivilizatsiya kazakhov: osnovy zhiznedeyatel'nosti nomadnogo obshchestva [Nomadic Civilization of Kazakhs: The Basics of the Life of a Nomad Society]. Almaty: "Sotsinvest"; Moscow: "Horizon", 1995. 320 p. (In Russian)

40. Min'yar-Belorucheva A.P. Tipologiya istoricheskogo diskursa [Typology of historical discourse]. Yazyk $i$ tekst [Language and Text]. 2015, vol. 2, no. 2, pp. 8-16. DOI:10.17759/langt.2015020202. (In Russian)

41. Nebol'sin P. Ocherki Volzhskogo Nizov'ya [Essays on the Volga Lower Region]. St. Petersburg, 1852. 197 p. (In Russian)

42. Nebol'sin P. Ocherki byta kalmykov Khoshoutovskago ulusa [Essays on the Life of Kalmyks in the Khoshout Ulus]. St. Petersburg, 1852. 190 p. (In Russian)

43. Nedashkovskiy L.F. Zemledelie, skotovodstvo, promysly i remesla [Agriculture, Cattle Breeding, and Crafts]. Zolotaya Orda v mirovoy istorii. Kollektivnaya monografiya [The Golden Horde in World History. Collective Monograph]. Kazan: Marjani Institute of History of Tatarstan Academy of Sciences, 2016, pp. 551-578. (In Russian)

44. Nedashkovskiy L.F. Zolotoordynskie goroda Nizhnego Povolzh'ya i ikh okruga [Golden Horde Cities of the Lower Volga Region and Their Districts]. Moscow: Oriental literature, 2010. 351 p. (In Russian)

45. Novokhar'kovskiy mogil'nik epokhi Zolotoy Ordy [Novokharkovsky Burial Ground of the Golden Horde's Era]. Voronezh: Voronezh State University publishing house, 2002. 200 p. (In Russian)

46. Olearius A. Opisanie puteshestviya v Moskoviyu i cherez Moskoviyu v Persiyu $i$ obratno [Description of Travel to Muscovy and through Muscovy to Persia and Back]. St. Petersburg: Publication by A.S. Suvorin, 1906. 582 p. (In Russian)

47. Pallas P.-S. Puteshestvie po raznym mestam Rossiyskogo gosudarstva, Ch. 2. Kn. 2: 1770 g. [Travel to Different Places of the Russian State, Part 2. Book 2: Year 1770]. St. Petersburg, 1786. 571 p. (In Russian)

48. Pilipchuk Ya.V. Osilist' ta zemlerobi u Dasht-i Kipchak [Settlement and farmers in the Dasht-i Kipchak]. Iileya: naukoviy visnik. Zbirnik naukovikh prats' [Gileya: Research Bulletin. Collected Works]. Kyiv, 2012, iss. 60. Available at: http://shron1.chtyvo.org.ua/Pylypchuk_Yaroslav/Osilist_ta_zemleroby_u_Dashti_Kypchak.pdf. (In Ukrainian)

49. Pletneva S.A. Kochevniki Srednevekov'ya. Poiski istoricheskikh zakonomernostey [Nomads of the Middle Ages. Search for Historical Patterns]. Moscow: Nauka, 1982. 186 p. (In Russian)

50. Pletneva S.A. Pechenegi i oguzy na Nizhnem Donu [Pechenegs and Oguzes on the Lower Don]. Moscow, 1990. 101 p. (In Russian) 
51. Radlov V.V. Iz Sibiri. Stranitsy dnevnika [From Siberia. Diary Pages]. Moscow: Nauka, 1989. 749 p. (In Russian)

52. Rudenko S.I. Bashkiry. Istoriko-etnograficheskie ocherki [Bashkirs. Historical and Ethnographic Essays]. Ufa: Kitap, 2006. 376 p. (In Russian)

53. Savel'eva T.V. Formirovanie srednevekovykh gorodov u kochevnikov (po materialam raskopok gorodishcha Talgar) [Formation of medieval cities among nomads (based on materials from excavations of the Talgar settlement)]. Vzaimodeystvie kochevykh kul'tur i drevnikh tsivilizatsiy [Interaction of Nomadic Cultures and Ancient Civilizations]. Alma-Ata: Nauka, 1989, pp. 432-438. (In Russian)

54. Sinitsyn F.L. Sovetskoe gosudarstvo i kochevniki. Istoriya, politika, naselenie. 1917-1991 [Soviet State and Nomads. History, Politics, and Population. 1917-1991]. Moscow: Centrpoligraph, 2019. 318 p. (In Russian)

55. Uskenbay Q. Levoe krylo Ulusa Dzhuchi v XIII - nachale XV veka [The left wing of the ulus of Jochi from the thirteenth to early fifteenth century]. Zolotaya Orda $v$ mirovoy istorii. Kollektivnaya monografiya [The Golden Horde in World History. Collective Monograph]. Kazan: Marjani Institute of History of Tatarstan Academy of Sciences, 2016, pp. 208-216. (In Russian)

56. Fedorov-Davydov G.A. Kochevniki Vostochnoy Evropy pod vlast'yu zolotoordynskikh khanov [Nomads of Eastern Europe under the Rule of the Golden Horde Khans]. Moscow: Moscow State University, 1966. 274 p. (In Russian)

57. Flerov V.S. "Goroda" $i$ "zamki" Khazarskogo kaganata. Arkheologicheskaya real'nost' ["Cities" and "Castles" of the Khazar Khaganate. Archaeological Reality]. Moscow: Bridges of culture/Gesharim, 2011. 264 p. (In Russian)

58. Khabdulina M.K. Drevnetyurkskiy kul'tovyy tsentr v Verkhnem Priirtysh'e [Ancient Turkic cult center in the Upper Cis-Irtysh region]. Trudy IV(XX) Vserossiyskogo arkheologicheskogo tsentra v Kazani [Proceedings of the IV (XX) All-Russian Archaeological Center in Kazan]. Kazan: Fatherland, 2014, vol. 3, pp. 545-547. (In Russian)

59. Khabdullina M.K. Zolotoordynskie pogrebeniya nekropolya Bozok (Tsentral'nyy Kazakhstan) [Golden Horde's burials of the Bozok necropolis (Central Kazakhstan)]. Drevnie kul'tury Severnogo Kitaya, Mongolii i Baykal'skoy Sibiri [Ancient Cultures of Northern China, Mongolia, and Baikal Siberia]. Ke xue chu ban she, 2015. (In Russian)

60. Khazanov A.M. Kochevniki i vneshniy mir [Nomads and the Outside World]. Third edition. Almaty: Dayk-Press, 2002. 604 p. (In Russian)

61. Khazanov A.M. Kochevye gosudarstva i gosudarstva kochevnikov.Tavtologiya ili istoriya? [Nomadic states and states of nomads. Tautology or History?]. Fenomen kochevnichestva $v$ istorii Evrazii. Nomadizm i razvitie gosudarstva: Sbornik materialov Mezhdunarodnoy nauchnoy konferentsii [The Phenomenon of Nomadism in the History of Eurasia. Nomadism and State Development: Proceedings of the International Research Conference]. Almaty: Dayk-Press, 2007, pp. 9-16. (In Russian)

62. Khlebnikova T.A. Keramika pamyatnikov Volzhskoy Bolgarii. K voprosu ob etnokul'turnom sostave naseleniya [Ceramics of Monuments of Volga Bulgaria. On the Issue of the Ethnocultural Composition of the Population]. Moscow: Nauka, 1984. 240 p. (In Russian)

63. Khozhdenie kuptsa Fedota Kotova v Persiyu [Travel to Persia of the Merchant Fedot Kotov]. Moscow, 1958. 110 p. (In Russian)

64. Chernykh E.N. Stepnoy poyas Evrazii: Fenomen kochevykh kul'tur [Eurasian Steppe Belt: The Phenomenon of Nomad Cultures]. Moscow: Manuscript Monuments of Ancient Rus', 2009. 624 p. (In Russian)

65. Engels F. Proiskhozhdenie sem'i, chastnoy sobstvennosti i gosudarstva [Origin of the family, private property, and the state]. Sochineniya K. Marksa i F. Engel'sa [Works of Karl Marx and Friedrich Engels]. Second edition, vol. 21, pp. 28-178. (In Russian)

66. Bacon E. Types of pastoral nomadism in Central and Southwest Asia. Southwestern journal of anthropology. 1954, vol. 10, pp. 44-68. 
67. Golden P.B. An Introduction to the History of the Turkic Peoples: Ethnogenesis and State Formation in Medieval and Early Modern Eurasia and the Middle East. Wiesbaden: Harrassowitz, 1992. 483 p.

68. Krader L. The ecology of nomadic pastoralism. International social science bulletin. 1959, vol. 11, no. 4, pp. 499-510.

69. Lyublyanovics K. The Cumans in medieval Hungary and the question of ethnicity. Annual of Medieval Studies at Central European University. Budapest: Central European University, 2011, no. 17, pp. 153-169.

70. Pálóczi Horváth A. Keleti népe k a középkori Magyarországon. Besenyők, úzok, kunok és jászok müvelödéstörténeti emlékei. Budapest; Piliscsaba, 2014. (In Hungarian)

71. Phillips D. Peoples on the Move. Introducing the Nomads of the World. London: William Carey Library, 2001.

72. Sigismund von Herberstein. Rerum Moscoviticarum Commentarii. London, 1852, vol. 2. (In Latin)

73. Spinei V. The Romanians and the Turkic Nomads North of the Danube Delta from the tenth to the mid-thirteenth century. Leiden; Boston, 2009. $521 \mathrm{p}$.

About the author: Vladimir A. Ivanov - Dr. Sci. (History), Professor of the Department of Russian History of the Bashkir State Pedagogical University named after M. Akmulla (3A, October Revolution Str., Ufa 450008, Russian Federation); ORCID: 0000-0002-7243-2588. E-mail: ivanov-sanych@inbox.ru 


\title{
ДЕНЕЖНОЕ ОБРАЩЕНИЕ БУЛГАРСКОГО УЛУСА ВО ВТОРОЙ ПОЛОВИНЕ XIV В.
}

\author{
Д.Г. Мухаметшин \\ Болгарский государственный историко- \\ архитектурный музея-заповедник \\ Болгар, Российская Федераиия \\ djamil78@list.ru
}

Цель исследования: на примере кладов монет Булгарского улуса и раскопа 199 Болгарского городища показать коренное изменение денежного обращения во второй половине XIV в.

Maтериаль исследования: клады с Болгарского городища, Каратунский клад, надчеканенные монеты с раскопа 199 Болгарского городища.

Результаты и научная новизна: после вхождения Болгара в состав Улуса Джучи в городе возобновился чеканка монет. Самые ранние монеты чеканились от имени халифа ан-Насира и Великих каанов Мунке, Ариг-Буги. С образованием Золотой Орды Болгар чеканил монеты от имени Менгу-Тимура и последующих правителей, а также массу анонимных и анэпиграфных монет, которые откладывались в клады. Клады являются показателем изменения денежного обращения в Золотой Орде. Клады времени Токтамыша очень велики. В связи с нехваткой монет, в обращение пускали надчеканенные и обрезанные монеты. Это характерная особенность денежного обращения Булгарского улуса.

Ключевые слова: Булгарский улус, вторая половина XIV в., клады, надчеканы, Каратунский клад, Болгарское городище, раскоп 199 Болгарского городища

Для цитирования: Мухаметшин Д.Г. Денежное обращение Булгарского улуса во второй половине XIV в. // Золотоордынское обозрение. 2021. Т. 9, № 2. С. 296313. DOI: $10.22378 / 2313-6197.2021-9-2.296-313$

\section{MONEY CIRCULATION IN THE BULGAR ULUS IN THE SECOND HALF OF FOURTEENTH CENTURY}

\author{
D.G. Mukhametshin \\ Bolgar State Historical and Architectural Museum-Reserve \\ Bolgar, Russian Federation \\ djamil 78@list.ru
}

\begin{abstract}
Research objectives: To reveal the radical change in money circulation in the second half of the fourteenth century, using the example of the coin hoards of the Bulgar ulus and the 199 excavation of the Bolgar settlement.

Research materials: These include the hoards of the Bolgar settlement, the Karatunsky hoard, and counter-minted coins from the 199 excavation of the Bolgar settlement.

Results and novelty of the research: The city of Bolgar began to resume minting coins after it was annexed to the ulus of Jochi. The earliest such coins were minted on behalf of
\end{abstract}


the Caliph an-Nasir and the Great Khans, Möngke and Ariq Böke. After the establishment of the Golden Horde, Bolgar minted coins on behalf of Mengu-Timur and subsequent rulers, as well as many anonymous and unepigraphic coins that have been found deposited in hoards. Hoards are an indicator of changes in monetary circulation in the ulus and they increased significantly during the reign of Toqtamish Khan. Counter-minted and trimmed coins appeared due to a shortage of coins; this is a characteristic feature of the monetary circulation of the Bulgar ulus.

Keywords: Bulgar ulus, second half of fourteenth century, hoards, counterminted coins, Karatunsky hoard, Bolgar settlement, 199 excavation of the Bolgar settlement

For citation: Mukhametshin D.G. Money Circulation in the Bulgar Ulus in the second half of fourteenth century. Zolotoordynskoe obozrenie=Golden Horde Review. 2021, vol. 9, no. 2, pp. 296-313. DOI: 10.22378/2313-6197.2021-9-2.296-313

Территория Волжской Булгарии в 40-е годы XIII в. вошла в состав Великой Монгольской империи. В Болгаре первоначально чеканились монеты с именем Насир ад-Дина и монеты от имени монгольских каанов Менгу, АригБуги. В дальнейшем Болгар становился одним из центров золотоордынской монетной чеканки. Судя по легендам, на монетах серебряный и медный чекан Болгара продолжался до 40-х гг. XIV в. Затем, до правления Шадибек-хана, название «Болгар» в монетных легендах не встречается. Появление имени Болгара на монетах начала XV в. нумизматы связывают уже с другим городом, «Новым Болгаром» - Казанью.

Состояние денежного обращения в Булгарском улусе и его коренное изменение во второй половине XIV в. наглядно показывают клады, находимые в Болгаре. По нашим сведениям, на территории Болгарского городища и его пригородов обнаружены 9 кладов XIII в., 18 кладов XIV в., 2 клада XV в. и 9 кладов медных монет. В это число вошли как комплексы, состоящие из 3-4 монет, так и клады, включающие в себя тысячи монет. Есть сведения еще о 2 кладах с неустановленным временем тезаврации.

C начала XIV в. по 1350 г. с территории Болгара и Улуса в целом неизвестно ни одного клада. Наиболее ранний клад XIV в. относится, судя по младшей монете, к 750 г.х. При стабильном экономическом и политическом положении Булгарского улуса, вероятно, все спрятанные в землю денежные накопления изымались их владельцами. Такое положение характерно для Золотой Орды в целом.

Bce болгарские клады XIV в. сокрыты в конце 50-х гг. - в первой половине 60-х гг. XIV в. Нами эти клады выделяются как вторая группа кладов. Так, пик тезаврации этой группы кладов падает на 764 г.х. (1362/63 гг.) 5 кладов, последний зарытый клад относится к 767 г.х. (1365/66 гг). Это вторая группа кладов, сокрытие которых связано с создавшейся социальнополитической обстановкой в Булгарском улусе после захвата города БулатТимуром. Ни в одном из кладов не отмечено наличие обрезанных монет. Возможно, именно в 764 г.х. была начата «реформа», приведшая к массовому обрезанию монет. В данном случае сокрытие последних кладов 767 г.х. может отражать завершение первого этапа «реформы» с нормой обрезания серебра в 1,10 г. Четкую норму обрезания в 1,10 г дают материалы Каратунского клада. В позднейших кладах эта весовая норма уже не фиксируется. 
Вместе с обрезанными монетами была пущена в обращение надчеканенная медь.

Болгарские клады по младшей монете распределяются следующим образом: 750 г.х. - 1, 759 г.х. - 1; 760 г.х. - 1, 762 г.х. - 2; 763 г.х. - 3; 764 г.х. - 5; 766 г.х. $-1 ; 767$ г.х. -2 ; 760 -е гг.х. -1 клад.

Вторая группа кладов сформирована в основном из монет Джанибека. Для нее характерно полное отсутствие в составе или наличие незначительного количества монет Токты и малое количество монет Узбека. В некоторых кладах монет Узбека нет совсем. Практически во всех кладах 2-й группы имеются в наличии монеты Мюрида. В 11 кладах из 13 имеются монеты Мюрида и в четырех - Хайр-Пулада. Только в двух кладах имеются более поздние монеты Азиз-Шейха. Это говорит о том, что формирование кладов 2-й группы в основном завершается монетами Мюрида.

По младшей монете клады 2-й группы распределяются следующим образом: 762 г.х. - 2 клада; 763 г.х. - 3 клада; 764 г.х. - 5; 766 г.х. - 1; 767 г.х. - 2. Динамика изъятия монет из обращения в виде кладов показывает, что пик их тезаврации падает на начало 60-х гг. XIV века, что обусловлено политической, экономической обстановкой в Булгарском улусе середины XIV века. По количеству монет в кладах из Болгар преобладают комплексы количеством от 10 до 100 монет - таких 12. От 100 до 500 монет - 9; от 500 до 1000 монет - 3; более 1000 монет - 2 клада.

Таким образом, клады Булгарского улуса некрупные, 2/3 кладов составляют клады от 10 до 500 монет. В то же время Нижнее Поволжье, Рязань и Мордовские земли дают значительно большее количество крупных кладов. Свыше 500 монет - всего 32 клада. Клады свыше 500 монет в Болгарах составляют $1,5 \%$; в Нижнем Поволжье и Заволжье - 10\%; по Мордовским землям и Рязани - $27 \%$ от общего количества кладов.

В Болгарах отсутствуют клады, относящиеся к 70-х гг. XIV в. Началом 80-х гг. датируется клад № 1 с младшей монетой Токтамыша 782 г.х. По своему составу и статистической характеристике он не отличается от кладов 60-х гг. Только наличие по одной монете Бердибека-II (789 г.х.) и Токтамыша выделяет его от вышеназванных. Точно такой же клад был обнаружен в 1867 г. в Спасском уезде [25, № 152б]. О метрологии этих кладов сведений нет. Скорее всего, они, как и клады 60-х гг., состояли из необрезанных монет. Тезаврация этих кладов, вероятно, связана с дестабилизацией обстановки в Булгарском улусе перед восшествием на трон Токтамыша и денежной реформой 782/1380 г. Возможно, в связи с реформой в Болгарах произошло дальнейшее снижение нормы обрезывания серебряных монет. А.Г. Мухамадиев полагает, что «новочеканенные монеты Токтамыша, попадая в Среднее Поволжье, обрезывались под вес 0,78 г» [14, с. 111].

Клады с небольшим количеством монет до токтамышевского периода являются личными сбережениями частных лиц. Отсутствие таких кладов в правобережье Волги показывает, что взятие Булат-Тимуром Болгара не повлияло на стабильность Горной стороны, не сопровождалось разрушением экономики края и товарно-денежных отношений. Надо полагать, что за этим событием последовал определенный отток населения в правобережье Волги и Предкамье. Это четко показывает перераспределение кладов и комплексов монет конца XIV века на территории Татарстана. 
С территории города Болгара и его пригорода происходит 9 комплексов медных монет. Про клад 1886 г., кроме того, что он был найден в районе АгаБазара, мы ничего не знаем. Остальные клады зафиксированы, и некоторые из них опубликованы. Клады состоят из однородных или близких по времени чеканки типов монет. Группа монет из шурфа включает монеты типа Ян. № 12, Ян. №40, Ян. №89. Пулы разновременные, и вряд ли они составляли единый комплекс. Малое их количество (4 шт.) не позволяет сделать окончательный вывод по этой находке.

Клады конца XIII - 70-х гг. XIV вв., которых много в округе Болгара, в Тетюшской стороне отсутствуют. Все известные клады Тетюш и его округи относятся к концу XIV в. и отличаются своей величиной: Тетюшский - более 10 тысяч; Мало-Атрясинский - более 13 тысяч; Каратунский - 24 тысячи монет. Все клады по своим составам одинаковы. Интерес представляет денежно-вещевой Карашамский клад, который состоит из 158 золотых, серебряных, электровых, хрустальных и стеклянных изделий. Монетная часть клада состоит из 102 серебряных монет, включающих дирхемы Джанибека Пулада. Исследовавший монеты А.Б. Булатов на основании наличия в кладе монет Пулада датировал клад началом XV века [6, с. 119]. Так же по единственной монете Пулада А.Б. Булатовым Мало-Атрясинский клад был датирован началом XV века. Однако А.Г. Мухамадиевым и Г.А. Фёдоровым-Давыдовым эти монеты были отнесены Бик-Пуладу. Таким образом, младшими монетами, то есть датирующими время зарытия клада, остаются монеты Токтамыша. Время зарытия этих крупнейших кладов монет совпадает со временем зарытия наиболее выразительного клада из этой серии - Каратунского. Концентрация крупных кладов в Тетюшском регионе, несомненно, связана с именем Токтамыша. Если Даниловский клад, небольшой по количеству монет, был зарыт после поражения Токтамыша на Кундурче, то крупные - Тетюшский, Мало-Атрясский, Каратунский - были изъяты из обращения после 1395 года, то есть после поражения Токтамыша на Тереке. Известно, что именно на горной стороне Токтамыш привел в порядок свои войска перед отправкой в Сибирь. Каратунский клад в основном состоит из монет Золотой Орды с небольшими включениями монет других монгольских династий. В кладе присутствуют единичные русские монеты, по одной монете Трапезунда и Червонной Руси. Вместе с кладом обнаружены четыре медных подражания золотоордынским монетам.

В золотоордынской части клада выделяется несколько разделов: монеты дотоктамышевского чекана, монеты хана Токтамыша, подражания золотоордынским монетам и монеты с надчеканками.

Первый раздел включает монеты практически всех золотоордынских ханов XIV века. В кладе присутствуют три монеты XIII в. и семь монет Токты чекана Хорезма 706 и 707 г.Х. Как исключение, единичные монеты XIII века присутствуют во многих крупнейших кладах второй половины XIV века. Например, в Тетюшском - 4 шт. [21, с. 383-384]. Монеты первого периода в основном чеканены в Сарае, Сарае ал-Джадид, Хорезме и Гюлистане (при Джанибеке). В кладе имеются единичные монеты Болгара, Мохши и закавказского чекана Джанибека. Во втором периоде к этим городам прибавляется Азак. Первый и второй периоды денежного обращения в кладе представлены приблизительно равным количеством монет $-6,17$ и $6,48 \%$. 
Это показывает, что до конца 60-х гг. XIV века не происходило сокращение потребностей рынка в средствах обращения. В третьем периоде сокращается чеканка монет в Азаке, Сарае и Сарае ал-Джадид, одновременно появляются новые центры чеканки монет Орду, Шахр ал-Джадид и др. О значительном изменении денежного обращения в 70-е годы XIV в. говорит и то, что в кладе монеты 1368-1380 гг. представлены почти в два раза меньше, чем в предшествующие периоды $-3,30 \%$.

Монеты Токты и последующих ханов Золотой Орды были в свободном обращении вплоть до 80-х гг. XIV века. Монеты дотоктамышевского чекана по периодам денежного обращения распределяются следующим образом: первый период (1310-1357) - 6,17\%; второй период (1357-1368) - 6,48\%; третий период (1368-1380) - 3,30\%.

Реформа Токтамыша, как и реформа Токты 1310 года, предполагала изъятие из обращения всех монет предыдущих выпусков. Поэтому в первые годы реформы было отчеканено большое количество монет. Из 18506 монет Токтамыша в Каратунском кладе 3727 (20,13\%) чеканены в первые годы правления, если предположить, что Токтамыш пришел к власти в конце 781 г.х. В кладе имеется только одна монета, чеканенная в 781 г.х. в Сарае ал-Джадид, хотя имеются токтамышевские монеты того же года Хорезма и Сыгнака. Массовая чеканка монет Токтамыша происходила в 782 г.х. Если бы монет было выпущено меньше, несмотря на запрещение, потребность рынка удерживала бы часть монет предыдущих выпусков в обращении, и хотя в первые годы правления чеканили много монет, фактически так и происходило. В Каратунском кладе пореформенные монеты составляют 17\%. Подавляющийся большинство монет Каратунского клада принадлежит Токтамышу $(77,12 \%)$, чеканенных практически во всех городах Золотой Орды, а также в Закавказье и Кок-Орде в 781-797 гг.х. Большинство монет Токтамыша чеканены в Сарае ал-Джадид $(32,84 \%)$, Орде $(25,99 \%)$, Сарае $(13,67 \%)$, Азаке $(14,6 \%)$.

Монеты Хорезма токтамышевского чекана в денежном обращении Золотой Орды практически не участвовали. Перевозки монет носили односторонний характер из Хорезма в Орду. Торговля обслуживалась системой безналичных расчетов и учета векселей [25, с. 215, 219]. Большинство монет Каратунского клада очень хорошей сохранности и следов обращения не имеют. Монеты Хорезма имеют дату чекана 781-789 г.х. Хорезм в 780-790 г.х. чеканил и анонимные монеты. Токтамыш сохранил за собой Хорезм до 791 г.х., а в 1387 и 1388 гг. предпринял два похода в Среднею Азию.

Монеты Чагатаидов и Тимура чеканены в Самарканде, монеты Тимура чекана Хорезма относятся к 781 г.х., то есть, чеканены до захвата Хорезма Токтамышем.

Клады 80-90-х гг. в Болгарах не обнаружены. Клады, выявленные в Булгарском улусе: Карашам, Малые Атрясы 1856, 1954, Малый Толкиш, Николаевка, из Спасского уезда и Каратун - очень велики. Часть из них включает золотые монеты, слитки серебра, золотые и серебряные украшения. Тезаврация их связана с поражением Токтамыша в 1391 году на Кондурче и в 1395 г. на Тереке.

От кладов из других регионов булгарские клады отличаются включениями большого количества обрезанных монет. Данные клады показывают концентрацию в руках отдельных людей огромного состояния и изменения то- 
варно-денежных отношений в Улусе. Обращение серебра на внутреннем рынке сохраняется, однако оно концентрируется в руках купцов, обслуживающих транзитную торговлю. Судя по топографии кладов, эти купцы проживали не в Болгарах - в области, все чаще подвергающейся нападениям и теряющей свое былое значение. Одновременно сужалась территория обращения серебра и меди. Если на территории современного Татарстана обнаружены более 60 местонахождений с монетами середины XIV в., то местонахождений монет 70-90-х гг. всего пять. В Болгарах найдены единичные серебряные монеты Орды 70-х гг. и монеты Токтамыша 80-х и 90-х гг. XIV в. Практически все поступавшие в Болгар монеты уходили в клады. В обращении ходили токтамышевская медь, надчеканенные медные монеты и обрезанное серебро, но и их доля среди монетных находок Болгара не более $3 \%$.

Каратунский клад свидетельствует, что после реформы Токтамыша весовая норма чеканки серебра на монетных дворах Сарай, Сарай ал-Джадид, Орда, Крым, Азак и Азак ал-Махруса в какое-то время была одинаковой и равнялась величине, несколько большей чем 1,41 г. Данные анализа монет Азака из азовского клада [16, с. 96, 97] в этом случае нельзя принимать во внимание, поскольку монеты этого клада, очевидно, были обрезаны несколько позднее и не отражают истинной весовой нормы чеканки монет.

Надчеканки на джучидских монетах, нередко встречающиеся среди нумизматического материала золотоордынских памятников, не стали объектом специального исследования. В связи с тем, что обнаруженный во время археологических работ материал в первую очередь требует датировки, специалисты в той или иной мере отражали их в своих работах. Надчеканки нашли отражение в работах С.А. Яниной. Она впервые сделала попытку их классификации и датировки. Она датирует их широко - второй половиной XIV началом XV вв. [31, с. 454-456]. После публикации С.А. Яниной материалов с Болгарского городища появилась публикация надчеканок с Бельджамена [7]. В отдельную группу выделяются русские надчеканки на золотоордынских монетах и их подражаниях. В настоящее время, в период интенсивного сбора источниковедческого материала, многие вопросы, связанные с надчеканенными монетами, остаются открытыми.

Монеты с надчеканками активно участвовали в денежном обращении, об этом свидетельствует широкая территория их распространения. Они найдены в культурном слое Джукетау и Казани, обнаружены в многочисленных поселениях Волги и Камы от Ульяновска до Чистополя.

Известны их находки в бассейне рек Казанки, Свияги, Актая и Майны. Надчеканки «адель», «хан» получили распространение и за пределами Булгарского улуса. Остальные известны только по материалам Болгара. Появление в обращении надчеканок нумизматы связывают со второй половиной 60-х гг. XIV в. [28, с. 50], верхней датой по встречаемости их в комплексах XIV века можно считать 1400 г. Монет XV в. с собственно золотоордынскими надчеканками нет [27, с. 50]. Надо полагать, что к началу массовой надчеканки монет легковесные монеты Джанибека вышли из обращения. Отдельные монеты 50-х гг. XIV в. (тип с розеткой) надчеканены. Возможно, эти полновесные монеты во второй половине 60-х гг. XIV в. находились еще в обращении. Массовой надчеканке подвергались полновесные монеты Хызр-хана чекана Сарая алДжадид и Гулистана. В Болгарах на монетах Хызра обнаружено 12 видов над- 
чеканок. Надчеканки впервые зафиксировали понижение курса пула. Тип с розеткой был заменен более тяжелой монетой Хызра, а она, соответственно, более тяжелыми монетами 765-768 гг. Таким образом, медные монеты поддерживали повышающийся курс серебряных монет.

Реформа 1380/81 г. заметно снизила вес медных пулов. Токтамышевская медь в значительном количестве поступала в Среднее Поволжье, часть из нее оказалась надчеканенной. На медных монетах времени Токтамыша отмечены надчеканки «хакан», «лировидная тамга». Самая поздняя надчеканенная монета датирована 791 г.х. Контрамаркирование в 80-е гг. XIV века медных монет Токтамыша показывает повышение курса серебра в отношении к меди и снижении веса обрезывания монет.

Имеющийся материал в какой-то мере позволяет определить датировку надчеканок и место их маркирования. Например, надчеканку «лировидная тамга», «хан» на медных монетах С.А. Янина связывала с Болгаром, надчеканку на серебре «кунья мордка» А.В. Орешников и последующие исследователи увязывали с Рязанью. Однако десятки надчеканок из-за их малочисленности нельзя увязывать с каким-либо определенным историческим центром.

В составе Каратунского и других кладов имеются буквенные, словесные и знаковые надчеканки. Надчеканка «адель» представлена тремя типами.

Надчеканка данного типа присутствует в кладе из Старого Крыма и в собрании Эрмитажа, на монетах Токты-Джанибека из коллекции Саратовского музея [30, №451/098], в каталоге Н. Шельди без указания места происхождения. В Каратунском кладе надчеканка «адель» отсутствует на монетах Токтамыша и более ранних правителей Мухаммада и Бик-Булада, в то же время монеты этих правителей составляют значительную часть нетоктамышевской части клада.

На материалах из Болгар данная надчеканка присутствует только на ранних монетах (Узбек, Джанибек). А.Г. Мухамадиев отмечает три типа надчеканок «адель», где наиболее поздней монетой является монета Абдаллаха чекана Шехр ал-Джадид. По его мнению, контрамаркирование предшествовало обрезанию монет, и надчеканенные монеты, «оставаясь долго в обращении, подверглись новому обрезыванию» [14, с. 113]. В Малоатрясинском кладе, которой он исследовал, трем типам надчеканок «адель» соответствует определенная весовая норма обрезывания от 0,88 до 0,68 г [14, с. 112, табл. 6]. В Каратунском кладе среди надчеканенных монет второго типа при среднем весе 1,42 г имеются единичные монеты весом в 1,15; 1,18; 1,25 г.

Это показывает, что обрезанные монеты с надчеканкой «адель» в Каратунском кладе по весу резко отличаются от обрезанных надчеканенных монет Малоатрясинского клада. То есть если обрезывание монет производилось, то по различным весовым нормам.

Надчеканка «адель» на медных монетах представлена территориально и хронологически значительно шире. В Болгарах она встречается на монетах Хызра-Токтамыша [34, с. 176]. На Водянском городище надчеканку «адель» можно встретить на пулах от 40-х гг. XIV до конца XIV вв. [7, табл. 11]. На сегодня нет достаточного материала для выделения вариантов, характерных только для определенной территории. Выделенные В.Б. Клоковым и В.П. Лебедевым варианты надчеканок «адель» из Водянского городища характерны и 
для Болгар, хотя в количественном отношении в Болгарах они встречаются меньше.

С.А. Янина надчеканку «адель» на основании весовой нормы обрезывания датировала первой четвертью XV в. В Каратунском кладе большинство надчеканок имеется на монетах Узбека, Джанибека и Бирдибека, по одной на монетах Токты, Кульпы, Науруза, Орду-Мелика, Абдаллаха и на двух монетах Хызра. Подражания, на которых зафиксированы надчеканка «адель», по типам близки к монетам Узбека и Абдаллаха. Их средний вес составляет 1,$40 ; 1,41$ г. Если при Джанибеке устанавливалась весовая норма дирхема 1,56 г, которая сохраняется и при Хызре [14, с. 100], а в начале 70-х гг. XIV в. вес дирхема снижается до 1,365 г, то в надчеканенных монетах наблюдается иная весовая норма, находящаяся в пределах 1,38-1,48 г.

Таким образом, монеты с надчеканкой «адель» имеют различный вес. Это говорит о том, что отдельные монеты, находясь длительное время в обращении, подвергались неоднократному обрезыванию. Верхний предел существования надчеканки «адель» нужно связывать с правлением Абдаллаха. На двух монетах Науруза, кроме надчеканки «адель», имеются другие надчеканки, которые встречаются только на монетах Токтамыша, то есть монеты с надчеканкой «адель» были Токтамышем контрамаркированы повторно.

Одним пунсоном надчеканены монеты: Токта Сарай ал-Махруса 710 г.х; Джанибек Сарай ал-Джедид 747 г.х.; Джанибек Гюлистан 753 г. х.; Науруз Гюлистан 761 г.х.; Бирдибек Гюлистан 759 г. х. Данный пунсон отсутствует на подражаниях, на которых использовались другие пунсоны, как нам кажется, более поздних вариантов.

Вторую значительную группу надчеканок Каратунского клада составляет надчеканка «рязанская тамга» [15, №420, табл. 7, №292].

Надчеканка «хан» зарегистрирована на двух монетах Узбека чекана Сaрая ал-Махруса. Надчеканка «хан» известна по находкам из Черкасской и Херсонской области, из Крыма, из Саратовского музея и Волжской Булгарии. На меди в большом количестве встречается в Болгарах (около 40 экз.). C.А. Янина датирует эту надчеканку периодом правления Абдаллаха.

В Крымском кладе 1983 г. было обнаружено 243 монеты Узбека с надчеканкой «хан». Надчеканка «двуногая тамга» в Каратунском кладе отмечена на монете Мухаммада. Она известна по материалам из Болгар [31, с. 456], Малоатрясинского клада [14, с. 112]. С.А. Янина датирует данную тамгу на основании веса монеты первой четвертью XV в., что требует корректировки.

Поскольку надчеканка предшествовала обрезанию, тамги Малоатрясинского клада можно датировать не позднее периода реформы Токтамыша, то есть 80-ми гг. XIV в. Однако надчеканенные монеты Каратунского клада к уточнению датировки «двуногой тамги» прибавить ничего не могут.

Отправным пунктом при определении даты надчеканки монет было наличие или отсутствие их на монетах Токтамыша. Надчеканки «адель», «хан», «тамга», «аллах» по этому принципу можно датировать дотоктамышским периодом. Надчеканки «адель» и «и» в сочетании с надчеканками «Б», «СП» также отсутствуют на монетах Токтамыша. Отдельные надчеканки присутствуют на монетах Токтамыша 782-789 гг.х., более половины из которых падают на 782 г.х. Ни одна монета 790-797 гг.х. не надчеканена. Таким образом, нижней датой данных надчеканок является 1388 г. 
При контрамаркировании надчеканку наносили на лицевую и оборотную стороны монеты. По-видимому, это принципиального значения не имело. В 94 случаях надчеканку наносили на лицевую сторону монеты. При подсчете на подражаниях за лицевую сторону взята сторона, где четко выделялась надпись «ас-султан». При контрамаркировании «рязанской тамгой» на большинстве дирхемов надчеканка размещена на лицевой стороне монет.

Значительное количество надчеканок на монетах самого Токтамыша не дает возможность увязывать надчеканки с реформой Токтамыша. Надчеканенные монеты клада имеют средний вес 1,405 , практически это совпадает со средним весом монет Токтамыша. Только монеты с надчеканкой «хан» и один из вариантов надчеканки «адель» имеют меньший вес. Естественно, при введении по новому курсу надчеканенные монеты имели бы вес меньше нормативного.

Денежная реформа Токтамыша была задумана изъятием из обращения более ранних монет и выпуском их в обращение, но реформа не была доведена до конца. Как было сказано выше, монеты Токтамыша 790-797 гг.х. не контрамаркированы. Поскольку монеты этих годов составляют более $50 \%$ монет Токтамыша, это не случайно.

Рассматривая монеты с Болгарского городища, С.А. Янина выделяет группу подражаний. Не указывая места их чеканки, она отмечает «заметные стилистические различия подражаний, найденных в кладах на территории Золотой Орды» [31, с. 456]. Г. А. Фёдоров-Давыдов на основе изучения монет Тихомировского клада выделил группу подражаний, изготовленных на мордовских землях [27, с. 174].

По своему составу апробированные монеты разделяются на три группы. Первая группа включает монеты Джанибека, Бирдибека и Хызра, которые в своем составе имеют приблизительно одинаковое содержание серебра. Монеты Джанибека содержат больше меди, а монеты Хызра - свинца.

Во вторую группу входят монеты Мухаммада-Шадибека, чеканенные не только в разных городах, но и в различных «нумизматических провинциях»Орду, Хорезм, Болгар. Процентное содержание серебра в этих монетах составляет 88,35-89,93\%, то есть значительно выше, чем в первой группе. За счет сокращения серебра в составе монет увеличивается доля свинца.

Смерть Бердибека в 1359 г. открыла новую страницу в истории Золотой Орды - эпоху междоусобиц, кровавых войн, разрушений основных торговых путей, падение экономики в итоге значительных перемещений населения на более спокойные земли. Не остались в стороне от этого процесса самые северные земли Улуса Джучи - Булгарский улус, бывшая территория Волжской Булгарии. Происшедшие отдельные изменения границы на северной и северо-западной окраине связаны с освоением населением Волжской Болгарии бассейна реки Казанки, левого притока Волги [24, с. 69-70], и захватом Дмитрием Московским и Олегом Рязанским «татарских мест» в бассейне рек Мокши и Цны. Центральная власть могла удерживать единство государства, только учитывая интересы феодальной знати оседлых областей и кочевой аристократии. В.Л. Егоров одной из главных причин проявления сепаратистских стремлений в середине XIV века называет резкое сокращение активной внешнеполитической и военной деятельности государства [4, с. 57]. В 60-е годы XIV века возникают противостоящие друг другу две крупные политические группировки, контролирующие определенную территорию. Когда в Са- 
рае ал-Джадид шла череда смены ханов, в западной части Улуса Джучи набирала силу группа феодалов под эгидой темника Мамая, все больше претендующего на главную роль в Золотой Орде.

Весной 1361 года Мамай впервые выступил против Сарайского правителя, в результате которого был убит Тимур-Ходжа. Источники отмечают, что при Мамае находился Абдаллах [18, с. 101]. Кильдибек был последним золотоордынским ханом, власть которого признавали как на правом, так и на левом берегу Волги. Правившие после Кильдибека ханы Мюрид, Хайр-Пулад, Пулад-Ходжа, Азиз-Шейх, Тулунбек, Черкесбек, Каганбек, Арабшах чеканили монеты исключительно на левом берегу Волги [4, с. 59]. Территория Крыма, Причерноморья и правый берег Волги находились в руках Мамая, где выпускались монеты от имени Абдаллаха, Мухаммада, Туляка. Де-факто обозначилось разделение Золотой Орды на две части.

Раскол государства создавал политическую сумятицу, так как борьба шла не только между Мамаем и сарайскими ханами. В различных частях государства появились отдельные феодалы, проявлявшие сепаратизм и пытавшиеся быть независимыми и от Мамая, и от сарайских ханов. В 1361 году от Золотой Орды отделился Хорезм [4, с. 60]. В том же году Хаджи-Тарханом и прилегающими к городу районами завладел Черкес-бек. На Урале (Сарайчук) шла борьба между Ильбаном и Алп-Ходжой. Некоторые претенденты, например, Черкес-бек, на время завладели Сараем.

Русские летописи в 1361 году отмечают, что «Булат-Тимур, князь Ордынский Болгары взял и все города по Волге и улусе и отня весь Волжский путь» [17, с. 233]. Булат-Тимур чеканил монеты в 1366/1367 г. В.В. Григорьев к чекану Булат-Тимура относит монеты, чеканенные от имени Джанибека II [2, с. 45]. В том же году земли по реке Пьяна захватил Секиз-бей, вслед за ним туда же прибыл Тагай. На мордовских землях образуется самостоятельное княжество с центром в Мохше. Там чеканил монеты и Кильдибек, что показывает признание в мордовских землях власти Кильдибека. Тагай, захватив Мохшу, начинает собственную монетную чеканку [8, с. 7, T.II. №31-34]. Русские летописи еще раз упоминают Тагая под 1365 годом. Он контролировал определенную территорию, однако трудно представить четкие границы его владений. На северо-западе владения Тагая ограничивались нижегородскими и рязанскими землями. В значительной степени северо-западная граница определялась природно-географическими факторами. Надо полагать, что границей между владениями Тагая и Булат-Тимура была река Сура. В.Л. Егоров пишет, что в районе р. Пьяна образовалось два самостоятельных княжества - Тагая и Секизбея - и территории их были небольшими, не имели четких границ [4, с. 62]. После 1365 г. ни Тагай, ни Секиз-бей в источниках не упоминаются. Наличие медных монет, чеканенных Булат-Тимуром в Мохше по типу серебряных [8, с. 39, №55, 56, т. II. №29.30], показывает, что Булат-Тимур правил и в Мохше, то есть Болгар и Мохша были объединены в один улус. Оформление фактически самостоятельных княжеств, позднее объединенных в один Булгарский улус, с интересом наблюдали как на западе, в Орде Мамая, так и на востоке, на левом крыле Золотой Орды. И Мамай, и Урус-хан понимали значение этих окраинных, но стратегически важных земель, через которые открывалась прямая дорога на Русь. Известны татарские исторические предания, зачисляющие Болгар в «юрт» Урус-хана. В то же 
время в 1377 г. Мамаю без всякого напряжения удалось в Болгарах поставить своего ставленника, что показывает вхождение Болгара в сферу влияния Мамая. В начале 80-х гг. XIV в. Болгар и Мохша вновь вошли в состав объединенной Токтамышем в единое государство Золотой Орды.

Как в 1391, так и в 1395 году Токтамыш после своего поражения ушел в булгарские земли.

Тимур преследовал Токтамыша, но, когда узнал, что в его тылу формируются войска под руководством Удурку, повернул обратно на Кавказ. В исторической литературе нет единого мнения по вопросу преследования Токтамыша Тимуром до булгарских земель и разрушения Тимуром Болгара в 1395 году. Русские летописи сообщают, что Тимур «пройде всю землю татарскую» [17, с. 247-248]. Практически были разрушены и сожжены большинство городов Золотой Орды. Эвлия Челеби пишет о 170 крупных городах, разрушенных Тимуром. Вошел ли в это число город Болгар? О разрушении Тимуром Болгара сообщают татарские исторические сочинения «Таварих Болгария» $[11$, с. 35-47] и «Дастани Аксак Тимур» [3, с. 23-32].

Известные татарские просветители Г.Н. Ахмаров и Ш.Б. Марджани, подробно разбирая приведенные в данных сочинениях исторические сведения, отрицали разрушения Тимуром Болгара [1, с. 54; 9, с. 194].

А.П. Смирнов, Б. Шпулер, М.Г. Сафаргалиев, М.А. Усманов считают, что отдельные отряды Тимура могли разрушить города Булгарского улуса. Р.Г. Фахрутдинов также полагал, что «не исключена возможность побега отдельных отрядов Тимура на Болгар» [24, с. 150].

На территории Булгарского улуса другого крупного города, кроме Болгара, археологически не выявлено. Поэтому историки, говоря о разрушении Болгара, подразумевают город Болгар, а не улус или область. Неуверенность историков в данном вопросе происходит из положения о том, что в конце XIV века Болгар потерял свое экономическое и политическое значение и не мог быть для Тимура заманчивой добычей.

Токтамыш после поражения на Кавказе ушел в булгарские земли. Где он провел зиму 1395/1396 гг., источники не сообщают. Весной 1396 года он появляется в Крыму. Маловероятно, что Токтамыш с большим количеством войск оставался зимовать в Булгарском улусе. Для этого потребовалось бы огромное количество провизии и фуража. Скорее всего, он зимовал в Сибири.

Токтамыш после поражения на время оставался в Булгарском улусе, однако начавшееся разорение Тимуром городов Золотой Орды после поражения Удурку заставило Токтамыша покинуть пределы Булгара. Известно, что часть войск Тимура дошла до Укека. Поняв, что с его уходом из Золотой Орды уйдет и его власть над Ордой, Тимур решил возвести на престол подставного хана и объявил сына Урус-хана Койричак-оглана ханом Золотой Орды. Но номинально власть Токтамыша сохранялась вплоть до 1398 года. На русских монетах имя Токтамыша исчезает после сражения на реке Ворскле в 1399 году [26, с. 15], и чеканится нечитаемое имя хана Токтамыша [26, с. 66].

После битвы на Тереке Тимур достиг своей главной цели - Золотая Орда стала ареной споров враждующих группировок и претендентов на трон. М.Г. Сафаргалиев отмечает, что после 1396 года в Золотой Орде существовали три группировки - это Токтамыш, Койричак-оглан и Тимур-Кутлуг [22, c. 429]. Токтамыш контролировал правобережную часть Среднего Поволжья, 
Крым, Русский улус и Нижнее Поволжье, а противники Тохтамыша - левобережную часть Волги [10, с. 144].

Монетные клады XV века показывают, что с переносом административного центра Булгарского улуса в Казань изменился и общественно-политическая и социально-экономическая жизнь Волго-Уральского региона.

Таблица №1. Раскоп 199. Серебро. Распределение по десятилетиям

\begin{tabular}{|c|l|c|c|}
\hline № п/п & Десятилетия & Количество & $\%$ \\
\hline 1 & 1250 гг. & 1 & 2,38 \\
\hline 2 & $1260-1270$ гг. & 1 & 2,38 \\
\hline 3 & $1270-1300$ гг. & 8 & 19,05 \\
\hline 4 & 1310 гг. & 1 & 2,38 \\
\hline 5 & $1320-1340$ гг. & 4 & $\mathbf{9 , 5 2}$ \\
\hline 6 & $1340-1357$ гг. & 14 & $\mathbf{3 3 , 3 3}$ \\
\hline 7 & $1358-1363$ гг. & $\mathbf{6}$ & $\mathbf{1 4 , 2 9}$ \\
\hline 8 & $\mathbf{1 3 8 0}$ гг. & 4 & $\mathbf{7 , 1 4}$ \\
\hline 9 & Неопределимые & 42 & $\mathbf{9 , 5 2}$ \\
\hline Итого & & & $\mathbf{9 9 , 9 9}$ \\
\hline
\end{tabular}

Таблица №2. Раскоп 199. Серебро. Распределение по монетным дворам

\begin{tabular}{|c|l|c|c|}
\hline № п/п & Монетный двор & Количество & $\%$ \\
\hline $\mathbf{1}$ & Болгар & $\mathbf{1 0}$ & $\mathbf{2 3 , 8 1}$ \\
\hline 2 & Сарай, Сарай ал-Махруса & $\mathbf{4}$ & $\mathbf{9 , 5 2}$ \\
\hline 3 & Сарай ал-Джадид & $\mathbf{1 2}$ & $\mathbf{2 8 , 5 7}$ \\
\hline 4 & Гулистан & 7 & $\mathbf{1 6 , 6 7}$ \\
\hline 5 & Азак & 2 & $\mathbf{4 , 7 6}$ \\
\hline 6 & Мохша & $\mathbf{1}$ & $\mathbf{2 , 3 8}$ \\
\hline 7 & Надчеканки & $\mathbf{2}$ & $\mathbf{4 , 4 6}$ \\
\hline $\mathbf{8}$ & Неопределимые & $\mathbf{4}$ & $\mathbf{9 , 5 2}$ \\
\hline Итого & & $\mathbf{4 2}$ & $\mathbf{9 9 , 9 9}$ \\
\hline
\end{tabular}

Таблица №3. Раскоп 199. Медь. Распределение по десятилетиям

\begin{tabular}{|c|l|c|c|}
\hline № п/п & Десятилетия & Количество & $\%$ \\
\hline 1 & $1250-1260$ гг. & 87 & 14,97 \\
\hline 2 & Конец ХІІІ в. & 1 & 0,17 \\
\hline 3 & $1270-1310$ гг. & 28 & 4,82 \\
\hline 4 & 1320 гг. & 3 & 0,52 \\
\hline 5 & $1330-1340$ гг. Времени Узбека & 81 & 13,94 \\
\hline 6 & $1340-1350$ гг. Времени Джанибека & 71 & 12,22 \\
\hline 7 & 1360 гг. & 32 & 5,51 \\
\hline 8 & 1370 гг. & 5 & 0,86 \\
\hline 9 & $1380-1390$ гг. Времени Токтамыша & 66 & 11,36 \\
\hline 10 & Али-Дервиш. & 43 & 7,40 \\
\hline 11 & Надчеканки & 130 & 22,55 \\
\hline
\end{tabular}




\begin{tabular}{|c|l|c|c|}
\hline 12 & $\begin{array}{l}\text { Иноземные времени Узбека } \\
\text { и Джанибека }\end{array}$ & $\mathbf{6}$ & 1,03 \\
\hline 13 & Заготовки & 7 & 1,20 \\
\hline 14 & Неопределимые & 8 & 1,37 \\
\hline 15 & ХVIII-XX вв. & 14 & 2,41 \\
\hline Итого & & 580 & 99,99 \\
\hline
\end{tabular}

Таблица №4. Раскоп 199. Медь. Распределение по монетным дворам

\begin{tabular}{|c|l|c|c|}
\hline № п/п & Монетный двор & Количество & $\%$ \\
\hline 1 & Болгар & $\mathbf{1 9 7}$ & $\mathbf{3 3 , 9 1}$ \\
\hline 2 & Сарай & $\mathbf{6 0}$ & $\mathbf{1 0 , 3 3}$ \\
\hline 3 & Сарай ал-Джадид & $\mathbf{9 3}$ & $\mathbf{1 6 , 0 1}$ \\
\hline 4 & Гулистан & $\mathbf{2 1}$ & $\mathbf{3 , 6 1}$ \\
\hline 5 & Орда & $\mathbf{1 0}$ & $\mathbf{1 , 7 2}$ \\
\hline 4 & Крым & $\mathbf{3}$ & $\mathbf{0 , 5 2}$ \\
\hline 6 & Мокша & $\mathbf{3}$ & $\mathbf{0 , 5 2}$ \\
\hline 7 & Хаджитархан & $\mathbf{2}$ & $\mathbf{0 , 3 4}$ \\
\hline 7 & Хорезм & $\mathbf{1}$ & $\mathbf{0 , 1 7}$ \\
\hline 8 & Барджин & $\mathbf{1}$ & $\mathbf{0 , 1 7}$ \\
\hline 9 & Без монетного двора & $\mathbf{2 6}$ & $\mathbf{4 , 4 7}$ \\
\hline 11 & Надчеканки & $\mathbf{1 3 1}$ & $\mathbf{2 2 , 5 5}$ \\
\hline 12 & Иноземные & $\mathbf{6}$ & $\mathbf{1 , 0 3}$ \\
\hline 13 & Заготовки & $\mathbf{7}$ & $\mathbf{1 , 2 0}$ \\
\hline 14 & Неопределимые & $\mathbf{8}$ & $\mathbf{1 , 3 7}$ \\
\hline 15 & ХУІІ-ХХ вв. & $\mathbf{1 4}$ & $\mathbf{2 , 4 1}$ \\
\hline Итого & & $\mathbf{5 8 2}$ & $\mathbf{9 9 , 9 9}$ \\
\hline
\end{tabular}

Таблица №5. Раскоп 199. Медь. Распределение надчеканок по типам

\begin{tabular}{|c|l|c|c|}
\hline №/I & Тип тамги & Количество & $\%$ \\
\hline $\mathbf{1}$ & Лировидная тамга & $\mathbf{1 0 3}$ & $\mathbf{7 9 , 2 3}$ \\
\hline $\mathbf{2}$ & зафар & $\mathbf{1 2}$ & $\mathbf{9 , 2 3}$ \\
\hline $\mathbf{3}$ & адел + зафар & $\mathbf{4}$ & $\mathbf{3 , 0 8}$ \\
\hline $\mathbf{4}$ & хан & $\mathbf{2}$ & $\mathbf{1 , 5 4}$ \\
\hline $\mathbf{5}$ & адел & $\mathbf{2}$ & $\mathbf{1 , 5 4}$ \\
\hline $\mathbf{6}$ & полумесяц & $\mathbf{2}$ & $\mathbf{1 , 5 4}$ \\
\hline $\mathbf{7}$ & гусиная лапа & $\mathbf{1}$ & $\mathbf{0 , 7 7}$ \\
\hline $\mathbf{8}$ & треугольники & $\mathbf{1}$ & $\mathbf{0 , 7 7}$ \\
\hline $\mathbf{9}$ & азиз + зафар & $\mathbf{1}$ & $\mathbf{0 , 7 7}$ \\
\hline $\mathbf{1 0}$ & дважды «Азиз хан» & $\mathbf{1}$ & $\mathbf{0 , 7 7}$ \\
\hline $\mathbf{1 1}$ & неясная & $\mathbf{1}$ & $\mathbf{0 , 7 7}$ \\
\hline Итого & & $\mathbf{1 3 0}$ & $\mathbf{1 0 0}$ \\
\hline
\end{tabular}




\section{СПИСОК ЛИТЕРАТУРЫ}

1. Ахмаров Гайнетдин: тарихи-документаль жыентык. Казан: Хетер, 2000. 384 б.

2. Григорьев В.В. Описание клада из золотоордынских монет, найденного близ развалин Сарая // Записки Санктпетербургского археологическо-нумизматического общества. Спб., 1850. Т. ІІ. Вып. 1. С. 1-63.

3. Дэфтере Чынгыз-намэ. Казань: «Иман» нэшрияты, 2000. 44 б.

4. Егоров В.Л. Историческая география Золотой Орды в XIII-XIV вв. М.: Наука, 1985. $248 \mathrm{c}$.

5. Загоскин Н.П. Описание клада золотоордынских и некоторых других монет, найденных в 1881 г. близ с. Малого Толкиша Чистопольского уезда Казанской губернии // Известия общества археологии, истории и этнографии. 1884. Т. III. С. 350-394.

6. Калинин Н.Ф., Халиков А.Х. Итоги археологических работ за 1945-1952 гг. Казань: Таткнигоиздат, 1954. 126 с.

7. Клоков В.Б., Лебедев В.П. Монетный комплекс с Селитренного городища. (Золотая Орда, город Сарай) // Древности Поволжья и других регионов. Нижний Новгород. 2000. Вып. 3. Т. 2. С. 68-74.

8. Кротков A.A. Два собрания джучидских монет // Труды Нижне-Волжского общества краеведения. Саратов: Издание Нижне-Волжского общества краеведения, 1930. Вып. 37. 42 с.

9. Марджани Шигабетдин. Мостафадел-эхбар фи эхвали Казан вэ Болгар. Казань: Татарстан китап нэшрияты, 1989. 416 б.

10. Миргалеев И.М. Политическая история Золотой Орды периода правления Токтамыш-хана. Казань: Алма-Лит, 2003. 164 с.

11. Мослими. Тэварихы Болгария (Болгар Тарихы). Казан: «Иман» нэшрияты, 1999. $100 \mathrm{c}$.

12. Мухаметшин Д.Г. Болгарский монетный двор во второй половине XIV начале XV вв. // Седьмая Всероссийская нумизматическая конференция. Тезисы докладов и сообщений. М., 1999. С. 67-68.

13. Мухаметшин Д.Г. Нумизматические материалы второй половины XIV начала XVI вв. К вопросу о казанской чеканке // Историко-археологические исследования Урало-Поволжья. Казань: РИЦ «Школа», 2006. 452 с.

14. Мухамадиев А.Г. Булгаро-татарская монетная система XII-XV вв. М.: «Наука», 1983. 162 с.

15. Орешников А.В. Русские монеты до 1547 г. М.: Археологический центр, 1996. $275 \mathrm{c}$.

16. Пономарев А.Л. Деньги Золотой Орды и Трапезундской империи. Квантитативная нумизматика и процессы средневековой экономики. М., 2002. 216 с.

17. Полное собрание русских летописей. СПб., 1885. Т. 10.

18. Полное собрание русских летописей. СПб., 1913. Т. 18.

19. Пьрсов Ю.Е. Каталог джучидских монет Саратовского областного музея краеведения. Казань: Издательство Казанского университета, 2002. 64 с.

20. Савельев П.С. Монеты джучидские, джагатайские, джелаиридские и другие, обращавшиеся в Золотой Орде в эпоху Тохтамыша // Записки Восточного Отделения Императорского Археологического Общества. 1857. Т. ХІІ. Выпуск первый. 180 с. Табл. I-V (Екатеринославский клад).

21. Савельев П.С. Монеты джучидские, джагатайские, джелаиридские и другие, обращавшиеся в Золотой Орде в эпоху Тохтамыша // Записки Восточного Отделения Императорского Археологического Общества. 1858. Т. ХІІ. Выпуск второй. C. 181-342. Табл. VI-IX (Тетюшский клад). 
22. Сафаргалиев М.Г. Распад Золотой Орды. На стыке континентов и цивилизаций...(из опыта образований и распада империй X-XVI вв.). М.: ИНСАН, 1996. C. $280-764$.

23. Усманов М.A. Татарские исторические источники XVII-XVIII вв. Казань: Издательство Казанского университета, 1972. 224 с.

24. Фахрутдинов Р.Г. Археологические памятники Волжско-Камской Булгарии и ее территория. Казань: Таткнигоиздат, 1975. 218 с.

25. Федоров-Давыдов Г.А. Клады джучидских монет (основные этапы развития денежного обращения и денежно-весовых систем в Золотой Орде) // Нумизматика и эпиграфика. 1960. Т. І. С. 94-192.

26. Федоров-Давыдов Г.А. Клад серебряных джучидских монет с Селитренного городища // Нумизматика и эпиграфика. 1980. Т. XIII. С. 58-76.

27. Федоров-Давыдов Г.А. Денежное дело и денежное обращение Болгара // Город Болгар. Очерки истории и культуры. М.: Наука, 1987.

28. Федоров-Давыдов Г.А. Денежное дело Золотой Орды. М.: ПАЛЕОГРАФ, 2003. 352 с. +40 с. ил.

29. Френ Х.М. Монеты Улуса Джучиева или Золотой Орды. СПб., 1832.80 с. + 18 табл.

30. Шельди Н.M. Булгаро-татарские монеты XII-XV вв. Казань: Издательство «Титул», 2002. $166 \mathrm{c}$.

31. Янина С.A. Джучидские монеты из раскопок и сборов Куйбышевской археологической экспедиции в Болгарах в 1946-1952 гг. // Материалы и исследования по археологии СССР. 1954. № 42. С. 424-484.

32. Янина С.А. Джучидские монеты из раскопок и сборов Куйбышевской археологической экспедиции в Болгарах в 1953-1954 гг. // Материалы и исследования по археологии СССР. 1958. № 61. С. 392-423.

33. Янина С.А. Джучидские монеты из раскопок и сборов Куйбышевской археологической экспедиции в Болгарах в 1957 году // Материалы и исследования по археологии СССР. 1960. № 80. С. 210-224.

34. Янина C.A. Общий обзор коллекции джучидских монет из раскопок и сборов Куйбышевской археологической экспедиции в Болгарах (1946-1958 гг.) // Материалы и исследования по археологии СССР. 1962. № 111. С. 153-176.

35. Янина С.А. Монеты Золотой Орды из раскопок и сборов Поволжской археологической экспедиции на Царевском городище в 1959-1962 гг. // Поволжье в средние века. М., 1970. С. 194-218.

Сведения об авторе: Джамиль Габдрахимович Мухаметшин - кандидат исторических наук, старший научный сотрудник Болгарского государственного историкоархитектурного музея-заповедника (422840, ул. Братьев Назаровых, 67, Болгар, Российская Федерация). E-mail:djamil 78@list.ru 


\section{REFERENCES}

1. Akhmarov Gaynetdin: tarikhi-dokumental' zhyentyk [Akhmarov Gainetdin: A Historical-documentary Collection]. Kazan: Kheter, 2000. 384 p. (In Tatar)

2. Grigor'ev V.V. Opisanie klada iz zolotoordynskikh monet, naydennogo bliz razvalin Saraya [Description of the hoard with Golden Horde's coins found near the ruins of Sarai]. Zapiski Sanktpeterburgskogo arkheologichesko-numizmaticheskogo obshchestva [Notes of the Saint-Petersburg Archaeological and Numismatic Society]. 1850, vol. II, iss. 1, pp. 1-63 + 4 tabl. (In Russian)

3. Deftere Chyngyz-name [Daftar-i Chingiz Namah]. Kazan: Iman, 2000. 44 p. (In Tatar)

4. Egorov V.L. Istoricheskaya geografiya Zolotoy Ordy v XIII-XIV vv. [Historical Geography of the Golden Horden from the thirteenth to fourteenth century]. Moscow: Nauka, 1985. 248 p. (In Russian)

5. Zagoskin N.P. Opisanie klada zolotoordynskikh i nekotorykh drugikh monet, naydennykh v $1881 \mathrm{~g}$. bliz s. Malogo Tolkisha Chistopol'skogo uezda Kazanskoy gubernii [Description of the hoard of the Golden Horde and some other coins found in 1881 near the village of Maly Tolkish, Chistopol district, Kazan province]. Izvestiya obshchestva arkheologii, istorii $i$ etnografii [Proceedings of the Society of Archaeology, History, and Ethnography]. 1884, vol. III, pp. 350-394. (In Russian)

6. Kalinin N.F., Khalikov A.Kh. Itogi arkheologicheskikh rabot za 1945-1952 gg. [The Results of Archaeological Work for 1945-1952]. Kazan: Tatar book publishing house, 1954. 126 p. (In Russian)

7. Klokov V.B., Lebedev V.P. Monetnyy kompleks s Selitrennogo gorodishcha (Zolotaya Orda, gorod Saray) [Coin complex from the Siletrennoe settlement (Golden Horde, Sarai city)]. Drevnosti Povolzh'ya i drugikh regionov [Antiquities of the Volga Region and Other Regions]. Nizhniy Novgorod, 2000, iss. 3, vol. 2, pp. 68-74. (In Russian)

8. Krotkov A.A. Dva sobraniya dzhuchidskikh monet [Two collections of Jochid coins]. Trudy Nizhne-Volzhskogo obshchestva kraevedeniya [Proceedings of the Lower Volga Society of Local History]. Saratov: Publication of the Lower Volga Society of Local History, 1930, iss. 37. 42 p. (In Russian)

9. Marjani Shigabetdin. Mostafadel-ekhbar fi ekhvali Kazan ve Bolgar. Kazan: Tatar book publishing house, 1989. 416 p. (In Tatar)

10. Mirgaleev I.M. Politicheskaya istoriya Zolotoy Ordy perioda pravleniya Toktamysh-khana [Political History of the Golden Horde during the Reign of Toqtamïsh Khan]. Kazan: "Alma-Lit”, 2003. 164 p. (In Russian)

11. Moslimi. Tevarikhy Bolgariya (Bolgar Tarikhy) [History of Bolgar]. Kazan: "Iman", 1999. 100 p. (In Tatar)

12. Mukhametshin D.G. Bolgarskiy monetnyy dvor vo vtoroy polovine XIV nachale XV vv. [Bolgarian mint in the second half of fourteenth and early fifteenth century]. Sed'maya Vserossiyskaya numizmaticheskaya konferentsiya. Tezisy dokladov i soobshcheniy [Proceedings of the Seventh All-Russian Numismatic Conference]. Moscow, 1999, pp. 67-68. (In Russian)

13. Mukhametshin D.G. Numizmaticheskie materialy vtoroy poloviny XIV nachala XVI vv. K voprosu o kazanskoy chekanke [Numismatic materials from the second half of fourteenth to beginning of sixteenth century. On the issue of Kazan coinage]. Istoriko-arkheologicheskie issledovaniya Uralo-Povolzh'ya [Historical and Archaeological Research of the Ural-Volga Region]. Kazan: School, 2006. 452 p. (In Russian)

14. Mukhamadiev A.G. Bulgaro-tatarskaya monetnaya sistema XII-XV vv. [Bulgaro-Tatar Monetary System from the twelfth to fifteenth century]. Moscow: Nauka, 1983. 162 p. (In Russian)

15. Oreshnikov A.V. Russkie monety do 1547 g. [Russian Coins before 1547]. Moscow: Archaeological center, 1996. 275 p. (In Russian) 
16. Ponomarev A.L. Den'gi Zolotoy Ordy i Trapezundskoy imperii. Kvantitativnaya numizmatika i protsessy srednevekovoy ekonomiki [Money of the Golden Horde and the Trebizond Empire. Quantitative Numismatics and the Processes of Medieval Economics]. Moscow, 2002. 216 p. (In Russian)

17. Polnoe sobranie russkikh letopisey [Complete Collection of Russian Chronicles]. St. Petersburg, 1885. Vol. 10. (In Russian)

18. Polnoe sobranie russkikh letopisey [Complete Collection of Russian Chronicles]. St. Petersburg, 1913. Vol. 18. (In Russian)

19. Pyrsov Yu.E. Katalog dzhuchidskikh monet Saratovskogo oblastnogo muzeya kraevedeniya [Catalog of Jochid Coins of the Saratov Regional Museum of Local History]. Kazan: Kazan University publishing house, 2002. 64 p. (In Russian)

20. Savel'ev P.S. Monety dzhuchidskie, dzhagatayskie, dzhelairidskie i drugie, obrashchavshiesya v Zolotoy Orde v epokhu Tokhtamysha [Jochid, Chaghataid, Jalairid, and others coins circulated in the Golden Horde during the Toqtamïsh era]. Zapiski Vostochnogo otdeleniya Rossiyskogo arkheologicheskogo obshchestva [Notes of the Eastern Branch of the Imperial Archaeological Society]. 1857, vol. 12, iss. 1. 180 p. (In Russian)

21. Savel'ev P.S. Monety dzhuchidskie, dzhagatayskie, dzhelairidskie i drugie, obrashchavshiesya v Zolotoy Orde v epokhu Tokhtamysha [Jochid, Chaghataid, Jalairid, and others coins circulated in the Golden Horde during the Toqtamïsh era] Zapiski Vostochnogo otdeleniya Rossiyskogo arkheologicheskogo obshchestva [Notes of the Eastern Branch of the Imperial Archaeological Society]. 1858, vol. 12, iss. 2, pp. 181-342. (In Russian)

22. Safargaliev M.G. Raspad Zolotoy Ordy [Dissolution of the Mongol Empire]. Na styke kontinentov $i$ tsivilizatsiy... (iz opyta obrazovaniy i raspada imperiy $X-X V I v v$.) [At the Junction of Continents and Civilizations (from the experience of the formations and the collapse of empires from the tenth to the sixteenth centuries)]. Moscow: Insan, 1996, pp. 280-764. (In Russian)

23. Usmanov M.A. Tatarskie istoricheskie istochniki XVII-XVIII vv. [Tatar Historical Sources of the seventeenth and eighteenth century]. Kazan: Kazan University publishing house, 1972. 224 p. (In Russian)

24. Fakhrutdinov R.G. Arkheologicheskie pamyatniki Volzhsko-Kamskoy Bulgarii $i$ ee territoriya [Archaeological Sites of the Volga-Kama Bulgaria and Its Territory]. Kazan: Tatar Book publishing house, 1975. 218 p. (In Russian)

25. Fedorov-Davydov G.A. Klady dzhuchidskikh monet (osnovnye etapy razvitiya denezhnogo obrashcheniya i denezhno-vesovykh sistem v Zolotoy Orde) [Hoards of Jochid coins (the main stages in the development of monetary circulation and monetaryweight systems in the Golden Horde)]. Numizmatika i epigrafika [Numismatics and Epigraphy]. 1960, vol. 1, pp. 94-192. (In Russian)

26. Fedorov-Davydov G.A. Klad serebryanykh dzhuchidskikh monet s Selitrennogo gorodishcha [A hoard of silver Jochid coins from Selitrennoe settlement] Numizmatika i epigrafika [Numismatics and Epigraphy]. 1980, vol. 13, pp. 58-76. (In Russian)

27. Fedorov-Davydov G.A. Denezhnoe delo i denezhnoe obrashchenie Bolgara [Monetary affairs and monetary circulation of Bolgar]. Gorod Bolgar. Ocherki istorii $i$ kul'tury [The City of Bolgar. Essays on History and Culture]. Moscow: Nauka, 1987. (In Russian)

28. Fedorov-Davydov G.A. Denezhnoe delo Zolotoy Ordy [Monetary Affairs of the Golden Horde]. Moscow: "Paleo-graph", 2003. 352 p. + 40 p. (In Russian)

29. Frähn Ch.M. Monety Ulusa Dzhuchieva ili Zolotoy Ordy [Coins of the Ulus of Jochi or the Golden Horde]. St. Petersburg, 1832. 80 p. (In Russian)

30. Shel'di N.M. Bulgaro-tatarskie monety XII-XV vv. [Bulgar-Tatar coins form the twelfth to fifteenth century] Kazan: "Titel”, 2002. 166 p. (In Russian) 
31. Yanina S.A. Dzhuchidskie monety iz raskopok i sborov Kuybyshevskoy arkheologicheskoy ekspeditsii v Bolgarakh v 1946-1952 gg. [Jochid coins from excavations and collections of the Kuibyshev archaeological expedition in Bolgars in 1946-1952]. Materialy $i$ issledovaniya po arkheologii SSSR [Materials and Research on Archaeology of the USSR]. 1954, no. 42, pp. 424-484. (In Russian)

32. Yanina S.A. Dzhuchidskie monety iz raskopok i sborov Kuybyshevskoy arkheologicheskoy ekspeditsii v Bolgarakh v 1953-1954 gg. [Jochid coins from excavations and collections of the Kuibyshev archaeological expedition in Bolgars in 1953-1954]. Materialy $i$ issledovaniya po arkheologii SSSR [Materials and Research on Archaeology of the USSR]. 1958, no. 61, pp. 392-423. (In Russian)

33. Yanina S.A. Dzhuchidskie monety iz raskopok i sborov Kuybyshevskoy arkheologicheskoy ekspeditsii v Bolgarakh v 1957 godu [Jochid coins from excavations and collections of the Kuibyshev archaeological expedition in Bolgars in 1957]. Materialy $i$ issledovaniya po arkheologii SSSR [Materials and Research on Archaeology of the USSR]. 1960, no. 80, pp. 210-224. (In Russian)

34. Yanina S.A. Obshchiy obzor kollektsii dzhuchidskikh monet iz raskopok i sborov Kuybyshevskoy arkheologicheskoy ekspeditsii v Bolgarakh (1946-1958 gg.) [General overview of the collection of Jochid coins from the excavations of the Kuibyshev archaeological expedition in Bolgars (1946-1958)]. Materialy $i$ issledovaniya po arkheologii SSSR [Materials and Research on Archaeology of the USSR]. 1962, no. 111, pp. 153-176. (In Russian)

35. Yanina S.A. Monety Zolotoy Ordy iz raskopok i sborov Povolzhskoy arkheologicheskoy ekspeditsii na Tsarevskom gorodishche v 1959-1962 gg. [Coins of the Golden Horde from excavations and collections of the Volga archaeological expedition at Tsarevskoe settlement in 1959-1962]. Povolzh'e v srednie veka [The Volga Region in the Middle Ages]. Moscow, 1970, pp. 194-218. (In Russian)

About the author: Dzhamil G. Mukhametshin - Cand. Sci. (History), Senior Research Fellow, Bolgar State Historical and Architectural Museum-Reserve (67, Brat'ev Nazarovykh Str., Bolgar 422840, Russian Federation). E-mail: djamil $78 @$ list.ru 
УДК 94(47).031"1393"(094)

DOI: $10.22378 / 2313-6197.2021-9-2.314-335$

\title{
ЯРЛЫК ХАНА ТОКТАМЫША ПОЛЬСКОМУ КОРОЛЮ \\ ВЛАДИСЛАВУ ІІ ЯГАЙЛУ 1393 ГОДА. ПРОБЛЕМА ПРОИСХОЖДЕНИЯ ДРЕВНЕРУССКОГО ТЕКСТА
}

\section{С.В. Полехов}

Российская академия народного хозяйства и государственной службы при Президенте Российской Федерации

Москва, Российская Федеращия

sergey.polekhov@gmail.com

Цель исследования: определить происхождение древнерусского текста ярлыкапослания хана Токтамыша королю польскому Владиславу II Ягайлу 1393 г., время и место его возникновения.

Материалы исследования: тюркский и древнерусский тексты ярлыка-послания хана Токтамыша королю польскому Владиславу II Ягайлу 1393 г., а также опубликованные и неопубликованные вспомогательные материалы.

Новизна и результаты исследования: установлено, что древнерусский текст ярлыка-послания хана Токтамыша королю польскому Владиславу II Ягайлу 1393 г. был написан в королевской канцелярии писцом Малохеем; этот текст представляет собой запись посольства ханских послов, чем и объясняется его избыточные сведения по сравнению с тюрским оригиналом.

Ключевые слова: Великое княжество Литовское, Польское королевство, Токтамыш, Владислав II Ягайло, дипломатика

Для цитирования: Полехов С.В. Ярлык хана Токтамыша польскому королю Владиславу II Ягайлу 1393 года. Проблема происхождения древнерусского текста // Золотоордынское обозрение. 2021. Т. 9, № 2. С. 314-335. DOI: 10.22378/23136197.2021-9-2.314-335

Благодарности: Публикация подготовлена при поддержке РФФИ, проект № 1729-09015 офи_м. Приношу искреннюю благодарность И.Ч. Грале, А.И. Груше, Д. Колодзейчику, В.Б. Крысько, М. Кулецкому, В.Н. Михайловскому, М.В. Моисееву, К.В. Петрову, В.В. Трепавлову, А. Шведе и М.А. Яницкому за консультации и снабжение литературой.

\section{THE YARLIQ OF TOKHTAMISH KHAN TO KING WLADYSLAW II JAGIELLO OF POLAND: THE PROBLEM OF THE OLD RUSSIAN TEXT'S ORIGINS}

\author{
S.V. Polekhov \\ Russian Presidential Academy of National Economy and Public Administration \\ Moscow, Russian Federation \\ sergey.polekhov@gmail.com
}

Abstract: Research objectives: The aim of the article is to trace the origins of the Old Russian text of Tokhtamish Khan's 1393-dated yarliq-letter to King Władysław II Jagiełło of Poland, as well as the place and time of its emergence. 
Research materials: The Turkic and the Old Russian texts of Tokhtamish Khan's 1393 yarlıq-letter to King Władysław II Jagiełło of Poland, as well as published and unpublished auxiliary materials.

Results and novelty of the research: It is established that the Old Russian text of Tokhtamish Khan's 1393 yarliq-letter to Władysław II Jagiełło of Poland was written down in the royal chancery by the king's Ruthenian scribe, Małochiej. This text was a record of the embassy of the khan's envoys which explains its additional information when compared to the Turkic original.

Keywords: Grand Duchy of Lithuania, Kingdom of Poland, Tokhtamish, Władysław Jagiełł, diplomatics

For citation: Polekhov S.V. The Yarliq of Tokhtamish Khan to King Władysław II Jagiełło of Poland: The Problem of the Old Russian Text's Origins. Zolotoordynskoe obozrenie $=$ Golden Horde Review. 2021, vol. 9, no. 2, pp. 314-335. DOI: 10.22378/23136197.2021-9-2.314-335

Acknowledgements: The publication was prepared with the support of the Russian Foundation of Basic Research, project 17-29-09015 ofi_m. I would like to express my gratitude to Hieronim Grala, Aliaksandr I. Hruša, Dariusz Kołodziejczyk, Vadim B. Krys'ko, Michał Kulecki, Maksim V. Moiseev, Vitaliy M. Mykhaylovśkyj, Konstantin V. Petrov, Vadim V. Trepavlov, Adam Szweda, and Marek A. Janicki for consultations and providing me with literature.

Ярлык (послание) ${ }^{1}$ хана Золотой Орды Токтамыша от 20 мая 1393 г., в котором он сообщал польскому королю Владиславу II Ягайлу о победе над мятежниками и требовал причитающуюся ему дань с подвластных королю земель, обнаружил в 1834 г. князь М.А. Оболенский среди бумаг Краковского коронного архива, переданных шестью годами ранее в Московский главный архив Министерства иностранных дел ${ }^{2}$. К несомненному подлиннику ярлыка, писанному уйгурским письмом и снабжённому ханским золотым нишаном, был приложен древнерусский текст послания. Требовалось прежде всего прочесть и перевести текст, написанный уйгурицей, а затем сопоставить его с древнерусским текстом. Задача оказалась непростой, поскольку тогдашние

${ }^{1}$ О ярлыках ханов Золотой Орды и их типологии, в которой выделяются ярлыкипослания, см.: [40, с. 7-8; 41]. В дальнейшем для краткости я буду называть его ярлыком или посланием, употребляя эти слова как синонимы. Оригинальный текст этого источника написан на языке тюрки - литературном языке Золотой Орды; учёные определяли язык ярлыка как джагатайский или чагатайский [33, с. 1-17; 39, с. 235], кыпчакский или турецкий [35] или хорезмско-тюркский [59, p. 223, n. 2]. Для краткости и удобства я буду называть этот текст тюркским. Перевод этого ярлыка называю древнерусским по преобладающим в нём языковым чертам.

${ }^{2}$ На шмуцтитуле дела об этом ярлыке в фонде Комиссии печатания государственных грамот и договоров при Московском главном архиве Министерства иностранных дел (МГАМИД) имеется пометка простым карандашом, очевидно, сделанная М.А. Оболенским: «Найден мною в бумагах Архива Царства Польского по сношениям с Турциею», но вдоль нижнего края слева написано: «С татарами» (Российский государственный архив древних актов [РГАДА]. Ф. 179. Оп. 1. Д. 472. Л. 2). О передаче из Петербурга в Москву дел Краковского коронного архива о внешних сношениях см.: [70, s. 45]. Согласно описанию А. Прохаски, в 1882 г. в МГАМИД хранились документы Краковского коронного архива о сношениях с крымскими татарами за 1514-1780 гг., с Турцией - за 1384-1791 гг. [65, s. 361-362]. Найти упоминание ярлыка в инвентарях Краковского коронного архива XVI-XVIII вв. мне не удалось. 
«ориенталисты» лишь начинали заниматься историей Золотой Орды, использовавшихся в ней языков, палеографией и дипломатикой ордынских документов. Пришлось обратиться к нескольким учёным - О.М. Ковалевскому, Х.Д. Френу, Я.И. Шмидту и Йозефу фон Гаммеру-Пургшталлю ${ }^{3}$. Они определили, что ярлык написан уйгурскими буквами, а О.М. Ковалевский первым сопоставил его с «белорусским переводом» и заключил, что последний «едва ли может назваться переводом, разве только переводом тогдашних знатоков» ${ }^{4}$. В ответе ему М.А. Оболенский предложил объяснение: «Но когда вспомним, что Татары имели обыкновение сверх ярлыков, писанных на Татарском языке, посылать Грамоты (такого же точно содержания, как ярлык), на языке, понятном тем, к кому оные бывали адресованы, то и оказывается весьма вероятным, что Славянская Грамота писана в стану Токтамыша, и прибавки, в ней находящиеся, не суть произвольные вставки переводчика, а добавки письмоводителя Токтамышева, которому вздумалось сделать оные тогда, когда ярлык был уже написан» ${ }^{5}$. Впоследствии М.А. Оболенский поместил это объяснение в предисловии к 13-му выпуску своего «Сборника», где намеревался издать ярлык, а затем и в отдельном издании. Благодаря этому оно прижилось в науке ${ }^{6}$.

К концу 1837 г. разбором ярлыка занялся другой казанский учёный мирза А.К. Казем-Бек, призванный на помощь О. М. Ковалевским. Транскрибировав тюркский текст арабским письмом и переведя его на русский язык, а затем сравнив этот перевод с древнерусским текстом, он заключил: «По этому переводу и также по переводу г. Ковалевского вы можете видеть неверности современного перевода, которые я приписываю или несовершенному знанию переводчика уйгурского письма или тому, что в древние времена эти переводчики основывали свои переводы на изустном сказании послов; почему некоторые прибавления в современном переводе я считаю за исторические фактыл» (далее приводились примеры таких прибавлений) $[45, \text { с. 37] }]^{7}$ В том же письме Казем-Бек писал, что работает над «маленьким рассуждением» об особенностях ярлыка, а уже к февралю 1838 г. переслал его Х.Д. Френу для представления Академии наук и, в случае её одобрения, последующей публикации $[43 \text {, с. } 45,95-96 \text {; репродукция письма на с. } 174]^{8}$.

В 1840 г. Оболенский начал хлопоты об издании ярлыка, который планировал поместить в очередном 12-м выпуске своего «Сборника», и спрашивал у Френа, удастся ли напечатать в Петербурге его текст уйгурицей, подобно тому как в Казани он уже отпечатан в арабской транскрипции 9 (стараниями мирзы Казем-Бека ${ }^{10}$ ). Однако дело застопорилось: в ноябре 1843 г. Оболенский писал П.А. Муханову, что издание «Сборника» едва ли продолжится, а вместо него он намерен издавать журнал под названием «Архив историче-

\footnotetext{
${ }^{3}$ Материалы этой переписки см.: РГАДА. Ф. 179. Оп. 1. Д. 472.

${ }^{4}$ Там же. Л. 54-56 (письма Н.А. Полевому от 26 ноября 1834 г. и 10 января 1835 г.).

5 Там же. Л. 68 об. - 69 (письмо М.А. Оболенского О.М. Ковалевскому от марта

6 Это объяснение воспроизведено уже в классическом труде: [53, s. 355-356, n. 9].

${ }^{7}$ Подлинник письма от 26 ноября 1837 г.: РГАДА. Ф. 179. Оп. 1. Д. 472. Л. 81-82.

${ }^{8}$ В статье, опубликованной в 1841 г. [12], ярлык Токтамыша не упоминается.

${ }^{9}$ РГАДА. Ф. 179. Оп. 1. Д. 472. Л. $40-42$ об.; Ф. 395. Оп. 1. Д. 417. Л. 214 - 216 об.

${ }^{10}$ См. его транскрипцию: [45, с. 14,16$]$.
} 1835 г.). 
ских сведений», первый том которого уже печатается ${ }^{11}$. Но и здесь ярлык не был издан. По-видимому, проблема заключалась в том, что никто не мог транскрибировать текст ярлыка уйгурицей.

Дело сдвинулось с мёртвой точки благодаря инициативе казанского учёного И.Н. Березина (1818-1896), который в апреле 1850 г. писал М.А. Оболенскому: «Всем трудившимся над ним (ярлыком. - С.П.) чего-нибудь недоставало: г-н Гаммер не знаком ни с монгольским, ни с древним тюркским, хотя и сведущ в истории азиатской; г-н Казем-Бек не знаком достаточно с историей и нисколько с монгольским; г-н Ковалевский не знаком с тюркским и пренебрегает историей; кроме того, оба последние ученые не занимались никогда подобными трудами» ${ }^{12}$. Отрекомендовав таким образом своих учёных предшественников, в том же письме И.Н. Березин вызвался издать и перевести ярлык при помощи Доржи Банзарова, «природного монгола», задачей которого была подготовка монгольской транскрипции текста. М.А. Оболенский планировал издать ярлык в своём «Сборнике», однако это намерение так и не было осуществлено: почти весь тираж 13-го выпуска, включающего ханские ярлыки, был уничтожен пожаром, и «уцелело несколько экземпляров, в листах, и то неполных, оказавшихся при разборе бумаг после покойного князя» [37, с. 367-368; $29 ; 30]^{13}$. В результате интенсивной переписки с М.А. Оболенским, профинансировавшим издание ${ }^{14}$, ярлык был издан в Казани отдельной книжкой [45]. Она получила определённый резонанс не только в науке, но и у читающей публики: рецензии, в которых воспроизводился перевод ярлыка, поместили «Современник» и «Библиотека для чтения», а также «Biblioteka Warszawska» [46; 47; 51]. Вскоре после выхода издания И.Н. Березин через своего товарища по Казанскому университету Н.Ф. Костылецкого (1818-1867) обратился к его ученику Ч.Ч. Валиханову с просьбой разъяснить некоторые выражения, но его ответ не имел последствий для науки [4, с. 121-141, ср. с. 34-37, 630-645]. Спустя 38 лет после публикации Березина перевод тюркского текста был уточнён В.В. Радловым, который снабдил его подробным комментарием [33]. В 1927 г. ряд уточнений в перевод внёс А.Н. Самойлович [35], во многом основываясь на сопоставлении тюркского текста с древнерусским. Впоследствии тюркский текст ярлыка переиздавался [16, с. 199 (книга впервые вышла на турецком языке в 1940 г.); 48, s. 39-41].

Значительно меньшим вниманием пользовался древнерусский текст памятника. Он был издан в той же книжечке, причём передан «готическим» шрифтом из-за неимения «славянского» в казанской типографии ${ }^{15}$, часть его

${ }^{11}$ РГАДА. Ф. 395. Оп. 1. Д. 417. Л. 18 об. - 19.

${ }^{12}$ РГАДА. Ф. 179. Оп. 1. Д. 353. Л. 1 - 1 об.

${ }^{13}$ К сожалению, во время моих визитов в отдел рукописей Российской национальной библиотеки в 2017-2019 гг. его сотрудникам не удалось разыскать хранившийся там сигнальный экземпляр 13-го выпуска, на который опирался при подготовке своей статьи К.В. Петров. По-видимому, в 179-м фонде РГАДА сохранились подготовительные материалы этого выпуска.

${ }_{15}^{14}$ РГАДА. Ф. 179. Д. 353.

15 «Благодаря бедности типографии, в которой он печатан, старинный русский перевод напечатан, за неимением славянских, готическими буквами; впрочем, и славянские буквы не спасли бы этого перевода, потому что для него нужны особенные сокращения, в обыкновенном славянском не употребительные; этот недостаток в будущности исправится изданием Сборника Вашего Сиятельства», - писал И.Н. Березин М.А. Оболенскому 
была воспроизведена на вклейке-факсимиле, а рукопись - описана в казанской публикации. Отсюда его перепечатал В.А. Розов [34, № 26]. В 1916 г. его опубликовал по подлиннику Е.Ф. Карский [14, с. 443-444] $]^{16}$, а в 1974 г. текст был воспроизведён по изданиям Березина и Розова в издании М.М. Пещак [7, № 58].

Согласно Рижскому мирному договору 1921 г. советская сторона обязалась передать Польше вывезенные оттуда ценности, в том числе архивные материалы. Среди них оказался и Токтамышев ярлык. В настоящее время тюркский подлинник хранится в Главном архиве древних актов в Варшаве ${ }^{17}$. Рукопись древнерусского текста мне не удалось разыскать ни в Варшаве, ни в Москве $^{18}$. Безрезультатными оказались и поиски факсимиле в бумагах учёных, которые могли работать с ним в XIX - начале XX в. ${ }^{19}$ Поэтому при его изучении остаётся опираться на публикации И.Н. Березина и Е.Ф. Карского.

С самого начала изучения ярлыка учёные отметили, что древнерусский текст содержит ряд избыточных известий, и задались вопросом: каково было происхождение этих известий и самого древнерусского текста? Иными словами, где он был написан - в ханской ставке или в канцелярии Ягайла? Исследователи справедливо обратили внимание на Токтамышев ярлык как на достаточно ранний источник о литовско-ордынских взаимоотношениях на начальном этапе польско-литовской унии, до походов Витовта в степь, и активно использовали его данные (в обеих версиях - тюркской и древнерусской), иногда делали из них далеко идущие выводы (например: [42, с. 112114]), как правило, повторяя мнение М.А. Оболенского о написании обоих текстов ярлыка в ставке Токтамыша. Но, как было показано выше, суждение это, по сути, случайно, поскольку не было результатом изучения обоих текстов, а предшествовало ему. Кроме того, ни М.А. Оболенский, ни его последователи не задавались простым вопросом: если тюркский текст ярлыка был

14 сентября 1850 г. (РГАДА. Ф. 179. Д. 353. Л. 51 об.). Этим надеждам не суждено было сбыться.

${ }^{16}$ Публикация Карского не была доступна Розову «благодаря обстоятельствам военного времени», что он отметил в «Дополнениях и поправках» к своему изданию. Публикация Е.Ф. Карского переиздана: [13, с. 585-586].

${ }^{17}$ Archiwum Główne Akt Dawnych. Zbiór dokumentów pergaminowych. № 5612. В начале 1990-х гг. его копия была передана в Казань. Ныне она хранится: Государственный архив Республики Татарстан. Ф. 169 (Коллекция документов по истории Татарстана, поступивших из архивов России, стран ближнего и дальнего зарубежья). Оп. 1. Ед. хр. 4. Информация М.В. Моисеева в письме от 8 февраля 2019 г.

${ }^{18}$ Согласно устной консультации М. Кулецкого (8 ноября 2018 г.), служебный архив Главного архива древних актов (archiwum zakladowe), в котором были собраны документы о реституции 20-х гг., полностью погиб в 1944 г. Известно, что передача в Варшаву славяно-русских документов оказалась серьёзной проблемой при реализации российскопольского мирного договора [63, s. 220, 247-248]. Мне осталась недоступной книга: [61].

${ }^{19}$ О рассылке факсимиле не только тюркского, но и западнорусского текста тогдашним «ориенталистам» писал сам М.А. Оболенский: [45, с. 5]; РГАДА. Ф. 179. Оп. 1. Д. 472. Л. 3 об. -4 (здесь уточняется, что речь идёт о гравюре). По опубликованным обзорам и архивным описям, а частично и de visu, были изучены фонды И.Н. Березина (Институт восточных рукописей Российской академии наук [ИВР РАН]. Архив востоковедов. Ф. 5), О.М. Ковалевского (Там же. Ф. 29; [3]), Х.Д. Френа (Санкт-Петербургский филиал Архива Российской академии наук [СПб АРАН]. Ф. 778), В.В. Радлова (Там же. Ф. 177. № 39) и А.К. Казем-Бека [27]. 
сочтён недостаточным, то почему же он не был переписан так, чтобы соответствовать древнерусскому тексту? Одинокой осталась точка зрения В.А. Розова, который отметил, что бумага с филигранью «Голова быка» была очень распространённой в Польше и Юго-Западной Руси, а древнерусский перевод мог быть сделан на незаписанной части листа с тюркским текстом. Решающим аргументом в пользу того, что древнерусский текст был написан позже тюркского, писцом канцелярии Ягайла, В.А. Розов счёл «орфографические приёмы русского писца» (впрочем, не называя их) [34, № 26, легенда]. Обращение к рукописи древнерусского текста ярлыка, хотя бы по фотокопии, могло бы подтвердить выводы исследователя, но оно оказалось невозможным для него.

Для оценки этих гипотез необходимо не только рассмотреть древнерусский текст ярлыка и внешний вид его рукописи, но и провести его систематическое сравнение с тюркским текстом, которого никто из исследователей не делал (такую попытку предпринимал лишь А.К. Казем-Бек). При этом, не имея возможности самостоятельно оценить точность транскрипции и перевода тюркского текста, я опираюсь на перевод В.В. Радлова и поправки А.Н. Самойловича. Древнерусский текст использован по изданию Е.Ф. Карского, а описание рукописи - по публикации М.А. Оболенского и подготовительным материалам к ней. В делении текста на элементы условного формуляра я следую Т.И. Султанову [39, с. 246], с той лишь разницей, что разделяю нотификацию и наррацию [15, с. 169-193].

Оба текста, тюркский и древнерусский, начинаются с интитуляции и инскрипции. Но в инскрипции древнерусского текста вместо имени употреблён титул - «къ королеви польскому». Далее, в нотификации, Токтамыш обращается к Ягайлу как к «нашему брат(у)». Эта характеристика повторена ниже, в сообщении об отправке к королю ханских послов Хасана и Туулу Ходжи. В тюркском тексте такой характеристики нет.

Целый ряд расхождений имеется в наррации. Если в тюркском тексте говорится просто о восшествии Токтамыша на престол, то в древнерусском уточняется, что речь идёт о его первом воцарении: «Коли есмь первое сълъ на ц(а)рьскомъ столь». В древнерусском тексте ханские послы названы в обратном порядке по сравнению с тюркским (сначала - Хасан, затем - Кутлубуга), здесь говорится просто об их отправке, тогда как в тюркском тексте они названы предводителями послов. В древнерусском же тексте сделано важное уточнение: «И наши послы нашли вас под городомъ под Троки стоАчи», что позволяет отнести их прибытие к лету 1382 г., когда Ягайло, воюя с Кейстутом, действительно осаждал Троки [69, s. 613-614; 75, s. 476479]. (Это хорошо согласуется с действиями Токтамыша на другом направлении - знаменитым походом на Москву, в котором хан участвовал лично ${ }^{20}$.) Об ответном посольстве Ягайла в тюркском тексте сказано: «Ты тогда же посылал к Нам своего вестника» ${ }^{21}$, чьё имя названо в древнерусском: «Вы пак послали есте к намъ посла вашего, литвина, на имА Невоиста». Одинаково датировано начало ордынской усобицы (1391 г.): в тюркском тексте «третьего года» («в позапрошлом году»), в древнерусском - «оу другомъ

20 Это правильно отметил Ф.М. Шабульдо [42, с. 117-118]. О взятии Москвы Токтамышем и его последствиях см.: [5, с. 100-113] (здесь же литература).

${ }^{21}$ Цитата приводится с учётом поправки А.Н. Самойловича [35, с. 226-227]. 
пакъ льтъ». В тюркском тексте о ней сказано гораздо лаконичнее, чем в древнерусском. В последнем эти события сразу названы «замятней», а мятежник Бекбулат - «племеньником», то есть родственником, Токтамыша [38, c. 418$]^{22}$; хотя говорится о двух группах изменников, не уточняется, в отличие от тюркского текста, что Бекбулат и Коджа-медин возглавляли огланов, а Бекиш, Турдучак-берди и Давуд - беков; о них говорится обобщённо: «КнАЗ(и) ГОЛовнии, мои были слуГи, и тии стали намъ ворогъ». Если в тюркском тексте сразу подчёркнута секретность посольства Едигея к Тимуру, то в древнерусском - злой умысел против Токтамыша. Далее в древнерусском тексте ещё раз подчёркнуто, что Тимур (дополнительно названный «ЖельзнаА нога») ополчился на Токтамыша «по Идикгиеву посольству», и уточняется, что он выступил в поход «шm Чорного пъска». Лишь затем в древнерусском тексте говорится, что Тимур пришёл на Токтамыша тайно; в результате тот узнал об этом, когда Тимур был «оу нашои державђ», и не успел собрать («испрАтати») все свои войска, а ограничился лишь находившимся при нём двором. Гораздо подробнее и яснее в древнерусском тексте говорится о «смятении» в войске, вызванном врагами Токтамыша, не названными в тюркском тексте: выясняется, что в начале сражения Бекбулат бежал, и «тогда вси люди, всА рать, на бЊгъ повернулисА». Если в тюркском тексте говорится лишь о том, что Бог смилостивился над Токтамышем и выдал в его руки врагов, которые названы по имени, то в древнерусском подчёркивается активная роль хана: «мы ихъ сказнили, такъ што шпАтъ не будутъ намъ пакостити». В завершении наррации древнерусского текста послы Токтамыша названы его «слугами», но здесь, в отличие от тюркского текста, не сказано, что они возглавляют более обширное посольство.

За наррацией следует диспозиция, начало которой в древнерусском тексте отмечено крестом. В древнерусском тексте подробнее, чем в тюркском, изложено требование платить дань с владений, находящихся под властью Ягайла и издавна дававших её Белой Орде (в тюркском тексте они названы подвластными хану); сами эти владения названы «кнАж(е)ниА, волости», что призвано подчеркнуть различный их статус. Согласно древнерусскому тексту, Токтамыш призывает Ягайла «искать своего» с владений, находящихся под ханской властью; при этом, однако, не сказано, что Ягайло должен уплатить эту дань явившимся к нему послам. Подробнее изложены в древнерусском тексте и условия свободной торговли купцов - «безъ приимъ, без пакости», здесь же появляется дополнение «и чорнымъ людемъ промъслъ» ${ }^{23}$.

В корроборации древнерусского текста добавлена обычная для дипломатики Западной и Южной Руси формула: «абы то крђпко было». Хронологическая дата тюркского текста: «в год курицы, по летосчислению 795-й, в 8 день месяца Реджеба» - в древнерусском переведена почти дословно: «курАчего

22 Бек-Булат, несомненно, был Чингизидом из ветви Тука-Тимуридов, но точная степень родства его и Токтамыша неизвестна [62, p. 786].

${ }^{23}$ Социальное определение «чёрные люди» могло восходить к реалиям как Орды, где оно означало простонародье (кара киши, кара халк), отличное от аристократии, так и Руси, где оно встречается в XIV в. применительно к податному сельскому населению на Северо-Востоке и низшим слоям полноправного городского населения на Северо-Западе $[6$, c. $210 ; 2]$. 
льта, а мъсАцА Иречипа $8{ }^{24}$ (в переводе на современное летосчисление 20 мая 1393 г.). Что же касается топологической даты, то она, по-видимому, немного модифицирована: в тюркском тексте её, скорее всего, следует понимать «когда орда была в Тане» (имеется в виду город Тана - Азак) [39, c. 236], а в древнерусском переводе - «оу шрдъ на оустьи Дону».

В самом конце ярлыка в древнерусском тексте имеется важное дополнение: Токтамыш призывает Ягайла свободно обмениваться посольствами, «как от(е)ць нашь, какъ w(т)ци ваши были за шдно...», предлагает свою помощь против Ягайловых врагов, а в случае необходимости требует его помощи.

Все эти расхождения древнерусского и тюркского текстов выглядят не случайными, они подчинены определённым идеям, которые можно резюмировать следующим образом: хан Токтамыш - законный правитель Орды, который по воле Всевышнего победил вероломных мятежников (чьи действия представлены суммарно, без подробностей) и вновь утвердил свою власть; с Ягайлом его связывают давние дружественные отношения, подчёркнутые употреблением слова «брат» (означавшего равноправие) и основанные на признании власти Ольгердовича над его владениями и уплате ордынской дани, за которой и явились ханские послы. Что касается содержательных отклонений древнерусского текста от тюркского, все они либо подтверждаются независимыми источниками, либо во всяком случае не противоречат им (см. также: [18; 19, с. 109-128]).

Внешний вид рукописей позволял однозначно оценить лишь характер тюркского текста. Как уже говорилось, подлинник ярлыка хранится в Главном архиве древних актов в Варшаве, в собрании пергаменных документов (!) под № 5612. В 2001 г. он реставрировался в Центральной лаборатории консервации архивных материалов этого архива Агатой Бонковской (Agata Bąowska), для него была изготовлена специальная папка. Тюркский текст написан уйгурским письмом на двух листах бумаги почти одинакового размера $-21,5 \times 40,4$ см и $21 \times 41,7$ см; на обоих имеется филигрань - Голова быка с одноконтурной звездой на шесте (в издании 1850 г. бумага названа «лощёной»). На первом листе рядом с текстом помещён золотой ханский нишан, а на обороте вдоль верхнего края, в загрязнённой части листа - архивная пометка, вероятно, почерком XVI в.: «Imp[eratoris] Tartarorum, non recognitae» («Татарского хана, не распознано»).

Поскольку рукопись с древнерусским текстом отыскать не удалось, при её оценке приходится опираться на её описание с приложенным факсимиле

${ }^{24}$ Привожу цитату по факсимиле в издании 1850 г. М.А. Оболенский, а впоследствии и Е.Ф. Карский пропустили букву «И» после названия месяца, которую, судя по факсимиле, нетрудно принять за одну из точек, из которых составлен крест, заполняющий часть конца строки. Скорее здесь следует видеть букву «И», обозначающую число «8»: до и после неё стоит по точке, последняя из которых - практически вплотную к букве. В пользу этого говорит и сопоставление с тюркским подлинником. И.Н. Березин, пересылая М.А. Оболенскому отпечатанный экземпляр издания, ещё не прошедшего цензуру, писал 14 сентября 1850 г.: «В переписи современного русского перевода проскользнула ошибка, недавно мною замеченная: Ваше Сиятельство опустили число 8 - И, которое довольно ясно стоит в подлиннике после слова РЕЧИПА: к сожалению, эта неточность уже поздно мною замечена» (РГАДА. Ф. 179. Оп. 1. № 353. Л. 51 об.; ср. обсуждение той же темы в письме А.К. Казем-Бека М.А. Оболенскому от 26 ноября 1837 г.: РГАДА. Ф. 179. Оп. 1. Д. 472. Л. 81). 
нескольких строк в первом издании и на публикации текста XIX - начала $\mathrm{XX} \mathrm{в.}{ }^{25}$ Согласно первому изданию, древнерусский текст был написан на двух листах «хлопчатой» бумаги шириной $4 \frac{7}{8}$ вершка и высотой $63 / 4$ вершка $(21,45 \times 29,7$ см); на первом из них имелась филигрань - Голова быка. Каждый лист первоначально был записан только с одной стороны, при этом на первом листе поместилось 32 строки текста, на втором - восемь с половиной строк, начиная со слов «на то все послали єсмо сеи нашь Арлыкъ...» На обороте первого листа был помещён перевод на польский язык, судя по почерку, XVII в., занимавший 30 строк. Внизу второго листа имелись пометки - латинская, почерком XV в. ("Legatio Tartarica in p[rese]nti 1[ite]ra Rutenicali continetur" «В этой русской грамоте содержится татарское посольство»), и польская, возможно, той же рукой, что и перевод (“Ruskich lt. 5"). На обороте второго листа красными чернилами была написана цифра 2.

Уже из этого описания можно сделать некоторые заключения. Древнерусский текст был писан убористым почерком, во всяком случае на первом листе, где среднее расстояние между линиями строк составляло менее $1 \mathrm{cm.}$ При этом окончание текста на втором листе начиналось с корроборации - его логического завершения. Создаётся впечатление, что писец очень старался уместить весь текст на первом листе, и лишь поняв, что ему это не удаётся, начал второй. На то, что этот текст был не «парадным», как тюркский, а «рабочим», указывают различные характеристики бумаги - «лощёная» для тюркского текста и «хлопчатая» для древнерусского.

Важнейшую роль при определении характера древнерусского текста сыграло опубликованное факсимиле нескольких его строк. Благодаря ему выяснилось, что текст написан почерком Малохея - хорошо известного писца королевской канцелярии, который ещё в августе 1392 г. служил подольскому князю Фёдору Кориатовичу, но очень скоро перешёл на службу к польскому королю Владиславу Ягайлу ${ }^{26}$. Известен целый ряд документов, написанных узнаваемой скорописью Малохея на королевской службе и датированных 1393-1404 гг. (в одной из грамот он назван по имени, благодаря чему можно утверждать, что и другие грамоты писал он) ${ }^{27}$. Ярлык Токтамыша оказывается одним из самых ранних таких текстов. Это позволяет парировать аргумент, выдвигавшийся сторонниками мнения о написании древнерусского текста ярлыка в ханской ставке, - совпадение или во всяком случае близость филиграней бумаги, на которой были написаны тюркский и древнерусский тексты. Это обстоятельство следует объяснять широчайшим распространением бумаги с филигранью «Голова быка»: в конце XIV в. она использовалась в канцеляриях и ордынского хана, и польского короля ${ }^{28}$. В августе 1393 г. Малохей действительно находился при королевском дворе: расходы на него отмечены

${ }^{25}$ [45, с. $18 ; 14$, с. 443$]$; РГАДА. Ф. 179. Оп. 1. Д. 472. Л. 110 - 114 об. (черновики того же предисловия). Польский перевод см.: [45, с. 24]. Польский текст был опубликован также в 1998 г. в журнале «Эхо веков» [44] - судя по воспроизведённым примечаниям, перепечатан из той же публикации середины XIX в.

${ }^{26} \mathrm{O}$ принадлежности западнорусского текста руке Малохея я упомянул в более ранней работе [32, с. 315, прим. 33].

27 [9, с. 351; 8; см. также: 64]. О принадлежности этих грамот (не считая «молдавских») одной руке писал уже В. Курашкевич [60, s. 342-344]. О Малохее см. также: [20, c. 193-194]. Не исключено, что он действовал ещё в 1420 г. [71, s. 233-234].

${ }^{28}$ Cр. данные о филигранях расходных книг конца XIV в.: [68, s. viii]. 
в реестрах подскарбия Хинчки под 18 августа и Корчинского вицепрокураторства под 31 августа ${ }^{29}$.

В результате происхождение древнерусского текста со всеми его отклонениями от тюркского удаётся объяснить следующим образом. Во время аудиенции у польского короля ханские послы произносили содержание вверенного им посольства на тюркском языке, с некоторыми отклонениями от текста ярлыка. Переводчик переводил его на древнерусский; этот перевод и записал Малохей.

Эта картина, сложившаяся в результате сопоставления рукописей тюркского и древнерусского текстов, хорошо вписывается в практику дипломатических контактов XIV-XVI вв. и в то немногое, что известно о приёме татарских послов в 1393 г.

Как показывают обширные материалы о взаимоотношениях Польского королевства с Тевтонским орденом, приёмы послов у короля могли принимать разную форму: это могли быть и торжественные аудиенции в присутствии королевских сановников, и пиры, и конфиденциальные беседы короля с послом через переводчика [72, s. 194-207]. К счастью, некоторые обстоятельства приёма татарского посольства королём в 1393 г. выясняются из польских источников, прежде всего из реестров подскарбия Хинчки, где фиксировались расходы на нужды королевского двора. В них под 13 августа этого года отмечены следующие расходы: русину, посланному в Луцк с татарами для их сопровождения, - 1/2 гривны (марки); за проживание татар на постоялом дворе в Кракове - 6 гривен; за расходы татар на пути к королю и на обратном пути - соответственно 3 и 4 гривны $[67, \text { s. 162] }]^{30}$. Примерно такие же суммы тратились на приём других посольств. Они не были исключительными для королевских финансов: так, на одного королевского брата Скиргайла или неназванного смоленского князя (Глеба Святославича?) в период их пребывания при Ягайловом дворе тратилось по 6-7 гривен в день. Личное распоряжение короля о выдаче денег свидетельствует о почтении, с которым были приняты ханские послы [72, s. 204; 67, s. 152-221 и по указ.; 68, s. 1-130 и по указ.]. Скорее всего, Ягайло принял посольство Токтамыша тогда же, в первой половине августа, находясь в Кракове.

У нас нет прямых свидетельств о том, на каком языке произносили содержание ханского ярлыка татарские послы. Но позднейшая практика контактов с тюрко-татарскими государствами [59, p. 223-237] позволяет заключить, что послы говорили на золотоордынском тюрки, а толмач переводил их речь на древнерусский. Иногда в московских посольских книгах отмечалось соответствие посольских речей ханскому посланию ${ }^{31}$. Это указывает на то, что послы могли и отклоняться от его текста. Аналогию истории с Токтамышевым ярлыком можно отыскать в XVI в. Когда московский посол Иван Но-

${ }^{29}$ [67, s. 163, 226]. Последнюю декаду августа Ягайло провёл в Новом Корчине в 70 км к юго-западу от Кракова [50, s. 44]. Перевожу польский термин „рodrzędztwo” (,podrzęctwo") словом, образованным от латинского названия должности - "viceprocurator".

${ }^{30}$ От Азака до Кракова примерно 1800 км по прямой линии. Такой путь при обычной для того времени скорости передвижения занял бы около 45 дней, но в реальности поездка татарских послов наверняка длилась дольше.

${ }^{31}$ См., например: [36, с. 171] («А что въ грамотахъ писано, то и рьчь»). 
восильцев в 1570 г. вручил азовскому дездару Джаферу (Сеферю) грамоту Ивана Грозного, выяснилось, что в Азове никто не может перевести её с русского языка. «И яз, холоп твои, вельл грамоту перевести толмачю, а писал с неђ по-татарски Сеферев дьяк», - писал Новосильцев царю ${ }^{32}$. Полагаю, что в 1393 г. работники ханской канцелярии, оформляя ярлык, изначально предусматривали перспективы сочетания письменной и устной коммуникации татарских послов с королём и его советниками (тем более что сам Ягайло, по собственному признанию, не умел ни читать, ни писать ${ }^{33}$ ). Уйгурская письменность занимала значимое место в дипломатической переписке Орды [1, c. 112-120], но были ли её знатоки в Польском королевстве конца XIV в. неизвестно $^{34}$; стоит напомнить, что отправка Токтамышевых послов с ярлыком имела место после какого-то перерыва, но ограничивался ли он «замятней», мы опять-таки не знаем ${ }^{35}$.

Надо полагать, что на аудиенции присутствовал кто-то из сановников, перечисленных в королевских документах от 14 и 17 августа [57, № 393; 58, № 1937]. Некоторые из них, но не все - сандомирский воевода Ян Тарновский, краковский воевода Спытко Мельштынский, подканцлер Клеменс Москожовский - были так или иначе связаны с Русью и Литвой и, возможно, понимали древнерусский язык. Это вряд ли можно сказать о сановниках Великой Польши, находившихся тогда в Кракове. Однако переговоры велись именно на древнерусском. С одной стороны, он был хорошо понятен Ягайлу - сыну великого князя литовского Ольгерда, долгие годы княжившего в Витебске, и тверской княжны Ульяны Александровны. Уже современники отмечали «литовско-русские» пристрастия польского короля, сохранившиеся у него с детства и юности, среди которых - его приверженность к живописи «на греческий манер» [10] или присутствие при его дворе многочисленных русских слуг ${ }^{36}$. Из литовско-русской княжеской семьи происходила и последняя жена Ягайла, Софья Гольшанская. С другой стороны, на Руси был накоплен богатый опыт коммуникации с татарами: не случайно их провожатым из Кракова в Луцк был некий русин.

Известно, что король и его подданные сталкивались с трудностями перевода при контактах с некоторыми соседями - например, с Тевтонским орденом. Избежать этих трудностей на других направлениях позволяло использование древнерусского языка. На нём велась переписка Ягайла с великими князьями литовскими (хотя широко известен случай, когда Ягайло говорил с Витовтом на литовском) [72, s. 139-146, 150-154, 168-176; 52, s. 194-218; 31,

${ }^{32}$ РГАДА. Ф. 89. Оп. 1. Кн. 2. Л. $44-44$ об.; [21, с. 63].

33 «На это король ответил, что он не умеет ни писать, ни читать: ему приходится выслушивать то, что ему читают», - писал комтур Торна Фридрих фон Венден комтуру Эльбинга Вернеру фон Теттингену 11 мая 1407 г. о недавних переговорах с Ягайлом [49, s. 70].

${ }^{34}$ Многочисленные уйгурские записи (главным образом монограммы писцов), выявленные в материалах Северо-Восточной Руси, относятся к XV в. [24; 25; 26; 11$].$

${ }^{35}$ Из самого факта, что ярлык Токтамыша дошёл до наших дней, не приходится делать далеко идущие выводы. Как отметил О. Халецкий, хранение некоторых писем XV в. в Краковском коронном архиве во второй половине XVI в. можно объяснить лишь случайностью [52, s. 196-197].

${ }^{36}$ Многочисленные слуги с русскими и литовскими именами упоминаются в расходных книгах периода правления Ягайла [67; 68]. См. об обслуге королевской охоты: [54, s. 35-36]. 
c. 531-533] и составлялись документы о взаимоотношениях с молдавскими господарями [55]; впрочем, в обеих сферах он постепенно уступал позиции латыни. Вероятно, он использовался и для коммуникации с соседними русскими землями, о которой известно очень мало.

Древнерусский язык использовался и для коммуникации Ягайла с его подданными в коронной Руси. Ирене Сулковской-Курасёвой, изучавшей королевскую канцелярию, было известно 28 древнерусских документов Ягайла, - посвящённых как внутренним делам, так и внешней политике, - сохранившихся в подлинниках, списках, латинских и польских переводах; из них 24 датируются 1387-1411 гг. [71, s. 59-61]. Самый известный пример «обратной связи» - послание перемышльского судьи Костки «великому королю Владиславу», то есть тому же Ягайлу, о сборе овса и денег в коронной Руси и о работах, выполненных в Медыке к королевскому приезду [34, № 18; 7, № 38], которое можно датировать августом-октябрём 1406, 1407 или 1408 г. $^{37}$

Проведённое исследование показало, что в оценке происхождения древнерусского текста, несмотря на несовершенство перевода тюркского оригинала, прав оказался А.К. Казем-Бек, а не М.А. Оболенский. Он был написан не в ханской, а в королевской канцелярии, достаточно опытным писцом Малохеем, а его отклонения от тюркского подлинника объясняются особенностями посольской церемонии (и сообщают о ней дополнительные подробности). Это не только подчёркивает значение древнерусского перевода ярлыка как исторического источника, но и позволяет точнее оценить происхождение социальной и политической терминологии этого необычного текста ${ }^{38}$.

37 Публикаторы датируют его широким периодом 1386-1418 гг., но эту датировку можно сузить по упоминанию «старосты Твориана» - Флориана из Корытницы, который фигурирует в должности русского генерального старосты с 16 марта 1406 г. по 14 марта 1411 г., и предстоящего приезда короля - очевидно, с обширным двором - в Медыку и Перемышль, где Ягайло за указанный период бывал в октябре 1406, 1407 и 1408 гг. [73, № 1156 , s. $149 ;$; , № 38, 40, 41; 50, s. 61-64]. Поскольку в послании упоминается прошедший день св. Иакова (25 июля), оно было написано в августе-октябре. Ср. приводившуюся в литературе датировку 1407-1408 гг.: [28, с. 29].

38 Когда эта статья находилась в печати, мне стала доступна книга О.В. Лицкевича [17]. В ней переизданы древнерусский текст ярлыка (по публикации В.А. Розова) и переводы И.Н. Березина и В.В. Радлова с учётом поправок А.Н. Самойловича (с. 764-768). В легенде справедливо говорится, что перевод сделан «в конце XIV в., т. е. в ближайшее время после 20 мая 1393 г., в канцелярии короля Владислава (Ягайла)», и столь же справедливо, но осторожно замечено: «Текст содержит некоторые дополнения по сравнению с оригиналом, поэтому не исключено, что он расширен с учётом содержания посольских речей» (с. 765). В тексте исследования о последнем говорится более определённо (с. 555). Высказанная здесь же гипотеза о том, что посольство Токтамыша с его ярлыком стало ответом на посольство Ягайла и Витовта (?), отправленное в конце 1392 или в начале 1393 г., представляется мне избыточной. 


\section{СПИСОК ЛИТЕРАТУРЫ}

1. Абзалов Л.Ф. Ханские писцы. Из истории становления и развития канцелярской службы ханов Золотой Орды. Казань: ЯЗ, 2011. $252+4$ с.

2. Алексеев Ю.Г. «Чёрные люди» Новгорода и Пскова (к вопросу о социальной эволюции древнерусской городской общины) // Исторические записки. М.: Наука, 1979. T. 103. C. $242-274$.

3. Биография и научное наследие востоковеда О. М. Ковалевского (по материалам архивов и рукописных фондов) / Валеев Р.М, Кульганек И.В. (ред.). СПб.; Казань: Петербургское востоковедение, 2020. $434+6+17$ с.

4. Валиханов Ч.Ч. Собрание сочинений в пяти томах. Алма-Ата: Издательство Академии наук Казахской ССР, 1961. Т. 1. $777+1$ с.

5. Горский А.А. Москва и Орда. М.: Наука, 2003. 214 с.

6. Горский А.А. Русское средневековое общество: историко-терминологический справочник. СПб.: Издательство Олега Абышко, 2019. 416 с.

7. Грамоти XIV ст. / Пещак М.М. (упор.). Київ: Наукова думка, 1974. 256 с.

8. Груша А.И. Когда и почему «руские» писари королей польских и великих князей литовских стали писать скорописью? // Lituanistyka i wschodoznawstwo. Studia dedykowane Profesorowi Krzysztofowi Pietkiewiczowi / Błaszczyk G., Skrukwa G., Studenna-Skrukwa M. (red.). Poznań: Uniwersytet im. Adama Mickiewicza w Poznaniu, Wydział Historii UAM, 2020. C. 79-89.

9. Груша А.И. Кризис доверия? Появление и утверждение правового документа в Великом Княжестве Литовском (конец XIV - первая треть XVI в.). СПб.; М.: Центр гуманитарных инициатив, 2019.598 c +8 л.

10. Груша A.I. "Чалавек, народжаны ў варварскай краіне”: Ягайла - яго тыпізаваныя паводзіны // Вялікае княства Літоўскае і яго суседзі ў XIV-XV стст.: саперніцтва, супрацоўніцтва, урокі. Да 600-годдзя Грунвальдскай бітвы. Матэрыялы Міжнароднай навуковай канферэнцыі, Гродна, 8-9 ліпеня 2010 г. Мінск: Беларуская навука, 2011. С. 157-170.

11. Грязнов А.Л. Дьяческие монограммы на духовных и договорных грамотах московских князей XV в. // Вспомогательные и специальные науки истории в XX начале XXI в.: призвание, творчество, общественное служение историка. Материалы XXVI Международной научной конференции. Москва, 14-15 апреля 2014 г. М.: РГГУ, 2014. С. 152-155.

12. Казем-Бек А., мирза. Исследование об уйгурах // Журнал Министерства народного просвещения. 1841. Ч. 31. Отд. II. С. 37-122.

13. Карский Е.Ф. Белорусы, Т. 1: Введение в изучение языка и народной словесности. Минск: Беларуская Энцыклапедыя, 2006. 656 с.

14. Карский Е.Ф. Западнорусский ярлык хана Золотой орды Тохтамыша к польскому королю Ягайлу 1392-1393 гг. // Карский Е.Ф. Труды по белорусскому и другим славянским языкам. М.: Издательство Академии Наук СССР, 1962. С. 443-444.

15. Каштанов С.М. Русская дипломатика. М.: Высшая школа, 1988. 231 с.

16. Kypam A.Н. Собрание сочинений, Кн. 1: Ярлыки и битики ханов Золотой Орды, Крыма и Туркестана в архиве музея дворца Топкапы. Казань: Институт истории им. Ш. Марджани АН РТ, 2014. 256 с.

17. Лицкевич O.B. «Летописец великих князей литовских» и «Повесть о Подолье»: опыт комплексного критического разбора. СПб.: Дмитрий Буланин, 2019. $928+$ $16 \mathrm{c}$.

18. Миргалеев И.М. Войны Токтамыш-хана с Аксак Тимуром. Казань: Институт истории АН РТ, 2003. $88 \mathrm{c.}$

19. Миргалеев И.М. Политическая история Золотой Орды периода правления Токтамыш-хана. Казань: Алма-Лит, 2003. 164 с. 
20. Михайловський В.М. На маргінесі документа подільського князя Федора Коріатовича від 1392 р. // Ruthenica. Київ: Інститут історії України НАН України, 2016. T. 13. С. $188-197$.

21. Моисеев М.В. Азов (Азак) в 1570 г. в донесении русского посланника Ивана Новосильцева // Средневековые тюрко-татарские государства. Казань: Институт истории им. Ш. Марджани АН РТ, 2019. Вып. 11. С. 60-66.

22. Морозов Д.А. Древнерусская надпись уйгурским письмом // Древняя Русь. Вопросы медиевистики. 2016. № 1 (63). С. 100-103.

23. Морозов Д.А. Древнерусская рукопись на среднеазиатской бумаге (Заполнившаяся лакуна славянской кодикологии) // Архив русской истории. М.: Археографический центр, 1994. Вып. 5. С. 193-200.

24. Морозов Д.А. «Каллиграфические загадки» Буслаевской псалтыри: взгляд с Востока // Россия и Христианский Восток. М.: Индрик, 2004. Вып. 2-3. С. 82-97.

25. Морозов Д.А. Уйгурские автографы московских дьяков (дополнение к древнерусской дипломатике) // Памяти Лукичёва. Сборник статей по истории и источниковедению. М.: Древлехранилище, 2006. С. 173-199.

26. Морозов Д.А. Уйгурская запись в древнерусской рукописи // Памятники культуры. Новые открытия. Письменность. Искусство. Археология. 2004. М.: Наука, 2006. С. $14-16,632,634$.

27. Наследие Мирзы Казем-Бека: История и современность. Доклады и сообщения Международной научной конференции (г. Казань, 20-21 ноября 2013 г.) / Валеев Р.М. (ред). Казань; СПб.; Баку: Фолиант, 2015. 493 с.

28. Пашин С.С. Перемышльская шляхта второй половины XIV - начала XVI века. Историко-генеалогическое исследование. Тюмень: Издательство Тюменского государственного университета, 2001. $171+1 \mathrm{c}$.

29. Петров К. В. «Сборник князя Оболенского. № 13» // Историческое источниковедение и проблемы вспомогательных исторических дисциплин. К 140-летию академика Николая Петровича Лихачёва (1862-1936) и 100-летию Дома Н.П. Лихачёва в Санкт-Петербурге. Тезисы докладов конференции. Санкт-Петербург, 3-5 декабря 2002 г. СПб.: Дмитрий Буланин, 2002. С. 58-63.

30. Петров К.В. «Сборник князя Оболенского. № 13» и неизданный «Архив» князя М.А. Оболенского // Вспомогательные исторические дисциплины. СПб.: Дмитрий Буланин, 2005. Вып. 29. С. 248-252.

31. Полехов С.В. Наследники Витовта. Династическая война в Великом княжестве Литовском в 30-е годы XV века. М.: Индрик, 2015. 712 с.

32. Полехов С.В. Ханское послание литовскому князю в прусском архиве (1432 г.) // «Вертоград многоцветный». Сборник к 80-летию Бориса Николаевича Флори. М.: Индрик, 2018. С. 307-322.

33. Радлов B.B. Ярлыки Тохтамыша и Темир-Кутлуга // Записки Восточного отделения Императорского Русского археологического общества. 1888. СПб.: Типография Императорской Академии наук, 1889. Т. III. Вып. I и II. С. 1-40.

34. Розов В. Українські грамоти, T. 1: XIV і перша половіна XV в. Київ: Друкарня Української Академії Наук, 1928. ii+ $176+75$ + ix с.

35. Самойлович А.Н. Несколько поправок к изданию и переводу ярлыков Тохтамыш-хана // Самойлович А.Н. Тюркское языкознание. Филология. Руника. М.: Восточная литература, 2005. С. 224-227.

36. Сборник Императорского Русского исторического общества, Т. 41: Памятники дипломатических сношений Древней России с державами иностранными. Памятники дипломатических сношений Московского государства с Крымскою и Нагайскою Ордами и с Турцией. СПб.: Тип. Ф. Елеонского и Ко, 1884. Т. I. хxii + 557 с. + 82 стб.

37. Сборник князя Хилкова. СПб.: Типография братьев Пантелеевых, 1879. $12+$ $580+35 \mathrm{c}$. 
38. Словарь древнерусского языка XI-XIV вв. М.: Азубковник, 2000. Т. 6. 606 с.

39. Султанов Т.И. Письма золотоордынских ханов // Тюркологический сборник. 1975. М.: Издательство «Наука»; Главная редакция восточной литературы, 1978. C. 234-251.

40. Усманов M.A. Жалованные акты Джучиева улуса XIV-XVI вв. Казань: Издательство Казанского университета, 1979. 320 с.

41. Усманов М.A. Термин «ярлык» и вопросы классификации официальных актов ханств Джучиева улуса // Актовое источниковедение. М.: Наука, 1979. С. 218 244.

42. Шабульдо Ф.М. Чи був ярлик Мамая на українські землі? (до постановки проблеми) // Центральна Україна за доби класичного середньовіччя: студії з історії XIV ст. Київ: Інститут історії України, 2003. С. 102-125.

43. Эпистолярное наследие российских востоковедов: Письма Мирзы А.К. Казем-Бека академику Х.Д. Френу (1831-1846 гг.). Казань: Артифакт, 2015. 213 с.

44. Ярлык Тохтамыша: второе возвращение // Гасырлар авызы - Эхо веков. 1998. № 1/2. С. 16-17.

45. Ярлык хана Золотой Орды Тохтамыша польскому королю Ягайлу 1392 1393 г. / Оболенский М.А. (ред.). Казань: Типография Н. Коковина, 1850. 70 с.

46. Ярлык хана Золотой орды Тохтамыша к польскому королю Ягайлу. 13921393 года. Издан князем М.А. Оболенским. 1850. Казань. В типографии Коковина. В 8-ю д. л. Стр. 70 // Современник. 1850. Т. 24. Отд. V. С. 18-23.

47. Ярлык хана Золотой Орды Тохтамыша к польскому королю Ягайлу. 13921393. Издан М.А. Оболенским, почетным членом Императорского Казанского Университета и Общества Любителей Отечественной Словесности. (Москва, 1850, в 8.) // Библиотека для чтения. 1851. Т. 106. Отд. VI. С. 1-5.

48. Altın Orda Hanlığına ait resmî yazışmalar / Melek Özyetgin A., Kemaloğlu İ. (eds). Ankara: Türk Tarih Kurumu Yayınları, 2017. 171 s.

49. Czacharowski A. Rola króla Władysława Jagiełły w pertraktacjach polskokrzyżackich przed wielką wojną // Acta Universitatis Nicolai Copernici. Historia. Toruń, 1990. No. 24. P. 51-71.

50. Gąsiorowski A. Itinerarium króla Władysława Jagiełły 1386-1434. Wyd. 2, poprawione i uzupełnione. Warszawa: Instytut Historii Polskiej Akademii Nauk, 2015. $172 \mathrm{~s}$.

51. Gołębiowski S. Jerłyk hana Złotej ordy Tochtamysza do polskiego króla Jagiełly, wydany przez Michała księcia Oboleńskiego. W Kazaniu. 1850 // Biblioteka Warszawska. 1853. T. 3 (ogólnego zbioru t. 51). P. 571-574.

52. Halecki $O$. Z Jana Zamoyskiego inwentarza archiwum koronnego. Materyały do dziejów Rusi i Litwy w XV wieku // Archiwum Komisyi Historycznej. Kraków: Nakładem Akademii Umiejętności, 1919. T. 12. Cz. 1. P. 146-218.

53. Hammer-Purgstall J. von. Geschichte der Goldenen Horde in Kiptschak, das ist der Mongolen in Russland. Pesth: C.A. Hartleben's Verlag, 1840.1+686 s.

54. Jaworski R. Łowy Władysława Jagiełły // Jaworski R., Chojnacki P. Z biografistyki Polski późnego średniowiecza. Studia pod red. M. Koczerskiej. Warszawa: DiG, 2001. P. 7-86.

55. Jaworski $R$. Miejsce łaciny w polsko-mołdawskich kontaktach dyplomatycznych u schyłku XIV i w XV wieku // Łacina jako język elit. Warszawa: DiG, 2004. P. 413-419.

56. Katalog dokumentów pergaminowych ze zbiorów Tomasza Niewodniczańskiego w Bitburgu / Tomaszewicz J., Zdanek M., Bukowskiego W. (red.). Kraków: Towarzystwo Naukowe Societas Vistulana, 2004. xxii + $290+24$ s.

57. Kodeks dyplomatyczny katedry krakowskiej Ś. Wacława. Cz. 2 / Piekosiński F. (wyd). Kraków: Nakładem Akademii Umiejętności, 1883. xxxviii + 597 s. + 4 k. tabl.

58. Kodeks dyplomatyczny Wielkopolski. Poznań: Nakładem Biblioteki Kórnickiej, 1879. T. 3. $1 \mathrm{xi}+1+789 \mathrm{~s}$. 
59. Kolodziejczyk D. The Crimean Khanate and Poland-Lithuania. International Diplomacy on the European Periphery $\left(15^{\text {th }}-18^{\text {th }}\right.$ century $)$. A Study of Peace Treaties Followed by Annotated Documents. Leiden; Boston: Brill, 2011. 1049 p.

60. Kuraszkiewicz W. Gramoty halicko-wołyńskie XIV-XV w. Studjum filologiczne // Byzantinoslavica. Praha: Orbis, 1932. Roč. 4. P. 335-364.

61. Mamczak-Gadkowska I. Archiwa państwowe w II Rzeczypospolitej. Poznań: Wydawnictwo Naukowe Uniwersytetu im. Adama Mickiewicza, 2006. $431+1 \mathrm{~s}$.

62. Mirgaleev I.M. Bek Bulat: from a military commander to a rebel // Золотоордынское обозрение. 2016. Т. 4, № 4. С. 784-789. DOI: 10.22378/2313-6197.2016-4-4.784789.

63. Pietrzkiewicz D. Spory o zbiory. Piotr Bańkowski - rewindykacja i ochrona dziedzictwa piśmienniczego. Pułtusk: Wydawnictwo Akademii Humanistycznej im. A. Gieysztora; Warszawa: Oficyna Wydawnicza ASPRA-JR, 2019. $429+1 \mathrm{~s}$.

64. Polechow S. Poręczenie za kniazia Żedywida a wydarzenia lat 1392-1393 w Wielkim Księstwie Litewskim // Zapiski Historyczne. 2020. T. 85. Zesz. 3. P. 71-104. DOI: 10.15762/ZH.2020.27.

65. Prochaska A. Archiwum Królestwa w Moskwie // Ateneum. Ogólnego zbioru t. 51. 1888. R. 13. T. 3. Zesz. 2. P. 358-366.

66. Prochaska A. Z Witoldowych dziejów // Przegląd Historyczny. 1912. T. 15. Zesz. 3. P. 259-270.

67. Rachunki dworu króla Władysława Jagiełły i królowej Jadwigi z lat 1388 do 1420 / Piekosiński F. (wyd). Kraków: Nakładem Akademii Umiejętności, 1896. viii + 616 + 2 s.

68. Rachunki królewskie z lat 1393-1395 i 1412. Rachunki podrzęctwa krakowskiego. Rachunki stacji nowosądeckiej / Wajs H. (oprac.). Warszawa: DiG, 1993. 4 + ix + 1 + $180 \mathrm{~s}$.

69. Scriptores rerum Prussicarum. Die Geschichtsquellen der preussischen Vorzeit bis zum Untergange der Ordensherrschaft / Hirsch Th. von, Töppen M., Strehlke E. (hrsg.). Leipzig: Verlag von S. Hirzel, 1863. Bd. 2. ii +866 s.

70. Siemieński J. Rewindykacja archiwów koronnych. Przygotowanie naukowe i wyniki // Archeion. Warszawa: Wydawnictwo Archiwów Państwowych, 1927. T. 1. P. 3360.

71. Sułkowska-Kurasiowa I. Dokumenty królewskie i ich funkcja w państwie polskim za Andegawenów i pierwszych Jagiellonów (1370-1444). Warszawa; Łódź: Państwowe Wydawnictwo Naukowe (Oddział), 1977. $286+8$ s.

72. Szweda A. Organizacja i technika dyplomacji polskiej w stosunkach z zakonem krzyżackim w Prusach w latach 1386-1454. Toruń: Wydawnictwo Naukowe Uniwersytetu Mikołaja Kopernika, 2009. 465 s.

73. Urzędnicy województwa ruskiego XIV-XVIII wieku (ziemie halicka, lwowska, przemyska, sanocka): Spisy / Przyboś K. (oprac.). Wrocław i in.: Zakład Narodowy im. Ossolińskich - Wydawnictwo PAN, 1987. $415 \mathrm{~s}$.

74. Wajs $H$. Rejestry podskarbiego Hinczki z lat 1393-1395 (bruliony a czystopis) // Archeion. Warszawa: Naczelna Dyrekcja Archiwów Państwowych, 1993. T. 91. P. 45-60.

75. Wigand von Marburg. Nowa kronika pruska / Zonenberg S., Kwiatkowski K. (prac.). Toruń: Towarzystwo Naukowe w Toruniu, 2017. $665+1 \mathrm{p}$.

Сведения об авторе: Сергей Владимирович Полехов - кандидат исторических наук, старший научный сотрудник Школы актуальных гуманитарных исследований Института общественных наук Российской академии народного хозяйства и государственной службы при Президенте РФ (119606, пр. Вернадского, 82, Москва, Российская Федерация); ORCID: 0000-0001-7866-7663. E-mail: sergey.polekhov@ gmail.com 


\section{REFERENCES}

1. Abzalov L.F. Khanskie pistsy. Iz istorii stanovleniya $i$ razvitiya kantselyarskoy sluzhby khanov Zolotoy Ordy [The Khan's Scribes. From the History of the Formation and Development of the Bureaucratic Service of the Golde Horde Khans]. Kazan: JaZ, 2011. $252+4$ p. (In Russian)

2. Alekseev Ju.G. "Chernye lyudi" Novgoroda i Pskova (k voprosu o sotsial'noy evolyutsii drevnerusskoy gorodskoy obshchiny) [The "black people" of Novgorod and Pskov (to the question of the social evolution of the Old Russian city community).] Istoricheskie zapiski [Historical Notes]. Moscow: Nauka, 1979, vol. 103, pp. 242-274. (In Russian)

3. Biografiya i nauchnoe nasledie vostokoveda O.M. Kovalevskogo (po materialam arkhivov $i$ rukopisnykh fondov) [Biography and Scholarly Heritage of the Orientalist O.M. Kowalewski (according to the materials of the archives and manuscript collections)]. Valeev R.M. and Kul'ganek I.V. (eds). St. Petersburg; Kazan: Saint Petersburg's Oriental Studies, 2020. $434+6+17$ p. (In Russian)

4. Valihanov Ch.Ch. Sobranie sochineniy v pyati tomakh [Collected Works in Five Volumes]. Alma-Ata: Publishing house of the Academy of Sciences of the Kazakh SSR, 1961, vol. $1.777+1$ p. (In Russian)

5. Gorskiy A.A. Moskva i Orda [Moscow and the Horde]. Moscow: Nauka, 2003. 214 p. (In Russian)

6. Gorskiy A.A. Russkoe srednevekovoe obshchestvo: istoriko-terminologicheskiy spravochnik [Russian Medieval Society: A Guidebook on Historical Terminology]. St. Petersburg: Oleg Abyshko publishing house, 2019. 416 p. (In Russian)

7. Hramoty XIV st. [Documents of the fourteenth century]. Peshhak M.M. (ed.). Kyiv: Scientific thought, 1974. 256 p. (In Ukrainian)

8. Grusha A.I. Kogda i pochemu "ruskie" pisari koroley pol'skikh i velikikh knyazey litovskikh stali pisat' skoropis'yu? [When and why did the Ruthenian scribes of the kings of Poland and the Grand Dukes of Lithuania started to write in cursive?]. Lituanistyka $i$ wschodoznawstwo. Studia dedykowane Profesorowi Krzysztofowi Pietkiewiczowi. Błaszczyk G., Skrukwa G., Studenna-Skrukwa M. (eds). Poznań: Uniwersytet im. Adama Mickiewicza w Poznaniu, Wydział Historii UAM, 2020, pp. 79-89. (In Russian)

9. Grusha A.I. Krizis doveriya? Poyavlenie i utverzhdenie pravovogo dokumenta $v$ Velikom Knyazhestve Litovskom (konets XIV - pervaya tret' XVI v.) [The Crisis of Trust? The Emergence and Formation of the Law Document in the Grand Duchy of Lithuania (from the end of fourteenth century to first third of sixteenth century)]. St. Petersburg; Moscow: Center for humanitarian initiatives, 2019. $598+8$ p. (In Russian)

10. Hrusha A.I. "Chalavek, narodzhany y̆ varvarskay kraine": Yagayla - yago typizavanyya pavodziny ["A man born into a barbarian land": Jagiełło - his typical behavior]. Vyalikae knyastva Litoy̆skae $i$ yago susedzi $\check{y}$ XIV-XV stst.: sapernitstva, supratsoy̆nitstva, uroki. Da 600-goddzya Grunval'dskay bitvy. Materyyaly Mizhnarodnay navukovay kanferentsyi, Grodna, 8-9 lipenya $2010 \mathrm{~g}$. [The Grand Duchy of Lithuania and Its Neighbors in the fourteenth and fifteenth century: Rivalry, Co-operation, Lessons. For the $600^{\text {th }}$ Anniversary of the Battle at Grunwald: Proceedings of the International Research Conference, Hrodna, July 8-9, 2010]. Minsk: Belarusian science, 2011, pp. 157-170. (In Belarusian)

11. Gryaznov A.L. D'yacheskie monogrammy na dukhovnykh i dogovornykh gramotakh moskovskikh knyazey XV v. [The dyaks' monograms on the testaments and treaties of the Moscow dukes of the fifteenth century]. Vspomogatel'nye $i$ special'nye nauki istorii v XX - nachale XXI v.: prizvanie, tvorchestvo, obshhestvennoe sluzhenie istorika. Materialy XXVI Mezhdunarodnoj nauchnoj konferencii. Moskva, 14-15 aprelja 2014 g. [Auxiliary Historical Studies in the twentieth and at the beginnig of twenty first century: 
Mission, Creative Work, and Social Service of a Historian]. Moscow: Russian State University for the Humanities, 2014, pp. 152-155. (In Russian)

12. Kazem-Bek A., mirza. Issledovanie ob ujgurah [A study about the Uighurs]. Zhurnal Ministerstva narodnogo prosveshhenija [Journal of the Ministry of National Education]. 1841, part 31, section II, pp. 37-122. (In Russian)

13. Karskiy E.F. Belorusy, T. 1: Vvedenie v izuchenie yazyka $i$ narodnoy slovesnosti [Belarusians, Vol. 1: The Introduction into the Study of the Language and Folklore]. Minsk: Belarusian Encyclopedia, 2006. 656 p. (In Russian)

14. Karskiy E.F. Zapadnorusskiy yarlyk khana Zolotoy ordy Tokhtamysha $\mathrm{k}$ pol'skomu korolyu Yagaylu 1392-1393 gg. [The West Russian yarlıq of the Golden Horde Toqtamïsh to Jagiełło, King of Poland, of 1392-1393]. Idem. Trudy po belorusskomu $i$ drugim slavyanskim yazykam [Works on the Belarusian and Other Slavic Languages]. Moscow: USSR Academy of Sciences publishing house, 1962, pp. 443-444. (In Russian and Old Russian)

15. Kashtanov S.M. Russkaya diplomatika [The Russian Diplomatics]. Moscow: "Higher school", 1988. 231 p. (In Russian)

16. Kurat A.N. Sobranie sochineniy, Kn. 1: Yarlyki i bitiki khanov Zolotoy Ordy, Kryma i Turkestana $v$ arkhive muzeya dvortsa Topkapy [Collected Works, Book 1: Yarliqs and bitikler of the Golden Horde, Crimea, and Turkestan in the Archive of Topkapı Palace Museum]. Kazan: Marjani Institute of History of Tatarstan Academy of Sciences, 2014. 256 p. (In Russian)

17. Lickevich O.V. "Letopisets velikikh knyazey litovskikh" i "Povest' o Podol'e": opyt kompleksnogo kriticheskogo razbora [The "Chronicle of the Grand Dukes of Lithuania" and the "Tale about Podole": An Attempt of Complex Critical Analysis]. St. Petersburg: Dmitrij Bulanin, 2019. $928+16$ p. (In Russian)

18. Mirgaleev I.M. Vojny Toktamysh-hana s Aksak Timurom [Khan Tokhtamish's Wars with Aksak Timur]. Kazan: Marjani Institute of History of Tatarstan Academy of Sciences, 2003. 88 p. (In Russian)

19. Mirgaleev I.M. Politicheskaya istoriya Zolotoy Ordy perioda pravleniya Toktamysh-khana [The Political History of the Golden Horde during the Rule of Toqtamïsh Khan]. Kazan: Alma-Lit, 2003. 164 p. (In Russian)

20. Mykhailovśkyi V.M. Na marhinesi dokumenta podilśkoho kniazia Fedora Koriatovycha vid 1392 r. [On the margin of the document of Fedor Koriatovich, Prince of Podillya, 1392]. Ruthenica. Kyiv: Institute of Hisory of the Ukrainian National Academy of Sciences, 2016, vol. 13, pp. 188-197. (In Ukrainian)

21. Moiseev M.V. Azov (Azak) v 1570 g. v donesenii russkogo poslannika Ivana Novosilceva [Azov (Azak) in 1570 in the Russian envoy Ivan Novosiltsev's report]. Srednevekovye tyurko-tatarskie gosudarstva [Medieval Turko-Tatar States]. Kazan: Marjani Institute of History of Tatarstan Academy of Sciences, 2019, iss. 11, pp. 60-66. (In Russian)

22. Morozov D.A. Drevnerusskaya nadpis' uygurskim pis'mom [An ancient Russian note transcribed in Uighur characters]. Drevnjaja Rus '. Voprosy medievistiki [Old Rus': Problems of Medieval Studies]. 2016, no. 1 (63), pp. 100-103. (In Russian)

23. Morozov D.A. Drevnerusskaya rukopis' na sredneaziatskoy bumage (Zapolnivshayasya lakuna slavyanskoy kodikologii) [An ancient Russian manuscript on Central Asian paper (the filled lacuna of Slavic codicology)]. Arhiv russkoj istorii [Archive of Russian History]. Moscow: Archaeographic center, 1994, iss. 5, pp. 193-200. (In Russian)

24. Morozov D.A. "Kalligraficheskie zagadki" Buslaevskoj psaltyri: vzgljad s Vostoka ["Caligraphic enigmas" of the Buslaev Psalter: an approach of an Orientalist]. Rossija i Hristianskij Vostok [Russia and the Christian East]. Moscow: Indrik, 2004, iss. 23, pp. 82-97. (In Russian)

25. Morozov D.A. Ujgurskie avtografy moskovskih d'jakov (dopolnenie $\mathrm{k}$ drevnerusskoj diplomatike) [The Uighur autographs of the Moscow dyaks (an addition to 
the Old Russian diplomatics)]. Pamjati Lukichjova. Sbornik statej po istorii $i$ istochnikovedeniju [To the Memory of Lukichjov. Collected Articles on the History and Source Studies]. Moscow: Archives, 2006, pp. 173-199. (In Russian)

26. Morozov D.A. Uygurskaya zapis' v drevnerusskoy rukopisi [An Uighur inscription in an Old Russian manuscript]. Pamjatniki kul'tury. Novye otkrytija. Pis'mennost". Iskusstvo. Arheologija [Monuments of Culture. New Discoveries. Writing. Art. Archaeology], 2004. Moscow: Nauka, 2006, pp. 14-16, 632, 634. (In Russian)

27. Nasledie Mirzy Kazem-Beka: Istorija i sovremennost'. Doklady i soobshhenija Mezhdunarodnoj nauchnoj konferencii (g. Kazan', 20-21 nojabrja 2013 g.) [The Heritage of Mirza Kazem-Bek: History and Modernity. Proceedings of the International Research Conference (Kazan, November 20-21, 2013)]. Valeev R.M. (ed.). Kazan; St. Petersburg; Baku: Foliant, 2015. 493 p. (In Russian)

28. Pashin S.S. Peremyshl'skaya shlyakhta vtoroy poloviny XIV - nachala XVI veka. Istoriko-genealogicheskoe issledovanie [The Przemyśl Nobility from the second half of fourteenth century to beginning of sixteenth century. A Historical-Genealogical Study]. Tyumen: Tyumen State University publishing house, 2001. $171+1$ p. (In Russian)

29. Petrov K.V. "Sbornik knyazya Obolenskogo. № 13" [The "Collection of prince Obolensky. No. 13"]. Istoricheskoe istochnikovedenie $i$ problemy vspomogatel'nyh istoricheskih disciplin. K 140-letiju akademika Nikolaja Petrovicha Lihachjova (18621936) i 100-letiju Doma N. P. Lihachjova v Sankt-Peterburge. Tezisy dokladov konferencii. Sankt-Peterburg, 3-5 dekabrja $2002 \mathrm{~g}$. [Historical Source Studies and the Problems of Auxiliary Historical Studies. To the $140^{\text {th }}$ Anniversary of Academician Nikolai Petrovich Likhachev and the $100^{\text {th }}$ Anniversary of N.P. Likhachev's House in St. Petersburg]. St. Petersburg: Dmitrij Bulanin, 2002, pp. 58-63. (In Russian)

30. Petrov K.V. "Sbornik knjazja Obolenskogo. № 13” i neizdannyj “Arhiv” knjazja M.A. Obolenskogo [The "Collection of Prince Obolensky. No. 13" and the unpublished "Archive" of prince M.A. Obolensky]. Vspomogatel'nye istoricheskie discipliny [Auxiliary Historical Studies]. St. Petersburg: Dmitrij Bulanin, 2005, iss. 29, pp. 248-252. (In Russian)

31. Polekhov S.V. Nasledniki Vitovta. Dinasticheskaya voina v Velikom knyazhestve Litovskom v 30-e gody XV veka [Vytautas's Successors. The Dynastic War in the Grand Duchy of Lithuania in the 1430s]. Moscow: Indrik, 2015. 712 p. (In Russian)

32. Polekhov S.V. Khanskoe poslanie litovskomu knyazyu v prusskom arkhive (1432 g.) [The Khan's letter to the Lithuanian Duke in a Prussian Archive (1432)]. "Vertograd mnogotsvetnyi". Sbornik k 80-letiyu Borisa Nikolaevicha Flori ["Multicolor Vertograd". Collection for the Eightieth Birthday of Boris Nikolaevich Florya]. Moscow: Indrik, 2018, pp. 307-322. (In Russian)

33. Radlov V.V. Jarlyki Tohtamysha i Temir-Kutluga [The yarliqs of Toqtamïsh and Temir Qutlug]. Zapiski Vostochnogo otdelenija Imperatorskogo Russkogo arheologicheskogo obshhestva. [Proceedings of the Oriental Section of the Imperial Russian Archaeological Society], 1888, vol. III, issues I and II. St. Petersburg: Printing house of the Imperial Academy of Sciences, 1889, pp. 1-40. (In Russian)

34. Rozov V. Ukrä̈śki hramoty, vol. 1: XIV i persha polovina XV v. [Ukrainian documents, Vol. 1: The fourteenth and first half of fifteenth century]. Kyiv: Printing house of the Ukrainian Academy of Sciences, 1928. ii $+176+75+$ ix p. (In Russian, Ruthenian, and Ukrainian)

35. Samojlovich A.N. Neskol'ko popravok k izdaniju i perevodu jarlykov Tohtamyshhana [Several corrections to the publications and translations of Toqtamïsh Khan's yarliqs]. Idem. Tjurkskoe jazykoznanie. Filologija. Runika [Turkic Linguistics. Philology. Runic Studies]. Moscow: Oriental literature, 2005, pp. 224-227. (In Russian)

36. Sbornik Imperatorskogo Russkogo istoricheskogo obshchestva, Vol. 41: Pamyatniki diplomaticheskikh snoshenii Drevnei Rossii s derzhavami inostrannymi. Pamyatniki diplomaticheskikh snoshenii Moskovskogo gosudarstva $s$ Krymskoyu $i$ 
Nagaiskoyu Ordami is Turtsiei [Collection of the Imperial Russian Historical Society, Vol. 41: Monuments of Diplomatic Relations of Old Russia with the Foreign States. Monuments of Diplomatic Relations of the Muscovite State with the Crimean Horde, the Nogai Horde, and Turkey]. St. Petersburg: Printing house of F. Eleonsky, 1884, vol. 1. xxii +557 p. +82 col. (In Russian)

37. Sbornik knjazja Hilkova [The Collection of Prince Khilkov]. St. Petersburg: Printing house of Panteleev brothers, 1879. $12+580+35$ p. (In Russian and Old Russian)

38. Slovar' drevnerusskogo jazyka XI-XIV vv. [Dictionary of the Old Russian Language from the eleventh to fourteenth century]. Moscow: Azubkovnik, 2000, vol. 6. 606 p. (In Russian)

39. Sultanov T.I. Pis'ma zolotoordynskih hanov [The letters of the khans of the Golden Horde]. Tjurkologicheskij sbornik, 1975 [Turkological Collection, 1975]. Moscow: Nauka; Main editorial office of oriental literature, 1978, pp. 234-251. (In Russian)

40. Usmanov M.A. Zhalovannye akty Dzhuchieva ulusa XIV-XVI vv. [Granted Charters of the Ulus of Jochi]. Kazan: Kazan State University Publ., 1979. 320 p. (In Russian)

41. Usmanov M.A. Termin "jarlyk" i voprosy klassifikacii oficial'nyh aktov hanstv Dzhuchieva ulusa [The term "yarlıq" and the problems of the classification of official acts of the ulus of Jochi]. Aktovoe istochnikovedenie [Source Studies of Acts]. Moscow: Nauka, 1979, pp. 218-244. (In Russian)

42. Shabul'do F.M. Chi buv yarlik Mamaya na ukraïns'ki zemli? (do postanovki problemi) [Was there Mamai's yarliq for the Ukrainian lands?]. Central'na Ukrai'na za doby klasychnogo seredn'ovichchja: studii' $z$ istorii' XIV st. [Central Ukraine during the Classical Middle Ages: Studies of the History of the fourteenth century]. Kyiv: Institute of History of Ukraine, 2003, pp. 102-125. (In Ukrainian)

43. Epistoljarnoe nasledie rossijskih vostokovedov: Pis'ma Mirzy A.K. Kazem-Beka akademiku H.D. Frenu (1831-1846 gg.) [Epistolary Heritage of the Russian Orientalists: Mirza A.K. Kazem-Bek's Letters to Academician Ch.D. Frähn (1831-1846)]. Kazan: Artifact, 2015. 213 p. (In Russian)

44. Jarlyk Tohtamysha: vtoroe vozvrashhenie [Toqtamïsh's yarlıq: the second return]. Gasyrlar avyzy= Eho vekov [The Echo of Centuries], 1998, no. 1/2, pp. 16-17. (In Russian)

45. Yarlyk khana Zolotoy Ordy Tokhtamysha pol'skomu korolyu Yagaylu 1392$1393 \mathrm{~g}$. [The Yarliq of the Golden Horde Toqtamïsh Khan to Jagiełło, King of Poland, 1392-1393]. Obolensky M.A. (ed.). Kazan: Printing house of N. Kokovin, 1850. 70 p. (In Russian and Old Tatar)

46. Yarlyk khana Zolotoy ordy Tokhtamysha k pol'skomu korolyu Yagaylu. 13921393 goda. Izdan knyazem M. A. Obolenskim. Kazan'. V tipografii Kokovina. V 8-ju d. 1. Str. 70 [The Yarliq of the Golden Horde Toqtamïsh Khan to Jagiełło, King of Poland, 1392-1393. Edited by prince M.A. Obolensky. Kazan: Printing house of N. Kokovin]. Sovremennik [Contemporary]. 1850, vol. 24, section 5, pp. 18-23. (In Russian)

47. Yarlyk khana Zolotoy Ordy Tokhtamysha k pol'skomu korolyu Yagaylu. 13921393. Izdan M. A. Obolenskim, pochetnym chlenom Imperatorskogo Kazanskogo Universiteta i Obshchestva Lyubiteley Otechestvennoy Slovesnosti. (Moskva, 1850, v 8.) [The Yarliq of the Golden Horde Toqtamïsh Khan to Jagiełło, King of Poland, 1392-1393. Edited by M.A. Obolensky, honorary member of the Imperial Kazan University and the Society of Connoisseurs of Russian Literature]. Biblioteka dlja chtenija [Library for Reading]. 1851, vol. 106, section 6, pp. 1-5. (In Russian)

48. Altın Orda Hanlı̆̆ına ait resmî yazışmalar. Melek Özyetgin A., Kemaloğlu İ. (eds). Ankara: Türk Tarih Kurumu Yayınları, 2017. 171 p. (In Turkish)

49. Czacharowski A. Rola króla Władysława Jagiełły w pertraktacjach polskokrzyżackich przed wielką wojną. Acta Universitatis Nicolai Copernici. Historia. Toruń, 1990, no. 24, pp. 51-71. (In Polish) 
50. Gąsiorowski A. Itinerarium króla Wtadysława Jagietty 1386-1434. Wyd. 2, poprawione $i$ uzupetnione. Warszawa: Instytut Historii Polskiej Akademii Nauk, 2015. 172 p. (In Polish)

51. Gołębiowski S. Jerłyk hana Złotej ordy Tochtamysza do polskiego króla Jagiełły, wydany przez Michała księcia Oboleńskiego. W Kazaniu. 1850. Biblioteka Warszawska. 1853, vol. 3 (51), pp. 571-574. (In Polish)

52. Halecki O. Z Jana Zamoyskiego inwentarza archiwum koronnego. Materyały do dziejów Rusi i Litwy w XV wieku. Archiwum Komisyi Historycznej. Kraków: Nakładem Akademii Umiejętności, 1919, vol. 12, part 1, pp. 146-218. (In Polish)

53. Hammer-Purgstall J. von. Geschichte der Goldenen Horde in Kiptschak, das ist der Mongolen in Russland. Pesth: C.A. Hartleben's Verlag, 1840. $1+686$ p. (In German)

54. Jaworski R. Łowy Władysława Jagiełły. Jaworski R., Chojnacki P. Z biografistyki Polski późnego średniowiecza. Studia pod red. M. Koczerskiej. Warszawa: DiG, 2001, pp. 7-86. (In Polish)

55. Jaworski R. Miejsce łaciny w polsko-mołdawskich kontaktach dyplomatycznych u schyłku XIV i w XV wieku. Łacina jako język elit. Warszawa: DiG, 2004, pp. 413-419. (In Polish)

56. Katalog dokumentów pergaminowych ze zbiorów Tomasza Niewodniczańskiego w Bitburgu. Tomaszewicz J., Zdanek M., Bukowskiego W. (eds). Kraków: Towarzystwo Naukowe Societas Vistulana, 2004. xxii $+290+24$ p. (In Polish)

57. Kodeks dyplomatyczny katedry krakowskiej Ś. Wacława. Part 2. Piekosiński F. (ed.). Kraków: Nakładem Akademii Umiejętności, 1883. xxxviii + $597+4$ p. (In Polish and Latin)

58. Kodeks dyplomatyczny Wielkopolski. Poznań: Nakładem Biblioteki Kórnickiej, 1879, vol. 3. 1xi $+1+789$ p. (In Polish and Latin)

59. Kołodziejczyk D. The Crimean Khanate and Poland-Lithuania. International Diplomacy on the European Periphery $\left(15^{\text {th }}-18^{\text {th }}\right.$ century). A Study of Peace Treaties Followed by Annotated Documents. Leiden; Boston: Brill, 2011. 1049 p.

60. Kuraszkiewicz W. Gramoty halicko-wołyńskie XIV-XV w. Studjum filologiczne. Byzantinoslavica. Roč. 4. Praha: Orbis, 1932, pp. 335-364. (In Polish)

61. Mamczak-Gadkowska I. Archiwa państwowe w II Rzeczypospolitej. Poznań: Wydawnictwo Naukowe Uniwersytetu im. Adama Mickiewicza, 2006. $431+1 \mathrm{p}$. (In Polish)

62. Mirgaleev I. M. Bek Bulat: from a military commander to a rebel. Zolotoordynskoe obozrenie $=$ Golden Horde Review, 2016, vol. 4, no. 4, pp. 784-789. DOI: 10.22378/2313-6197.2016-4-4.784-789.

63. Pietrzkiewicz D. Spory o zbiory. Piotr Bańkowski - rewindykacja i ochrona dziedzictwa piśmienniczego. Pułtusk: Wydawnictwo Akademii Humanistycznej im. A. Gieysztora; Warszawa: Oficyna Wydawnicza ASPRA-JR, 2019. $429+1$ p. (In Polish)

64. Polechow S. Poręczenie za kniazia Żedywida a wydarzenia lat 1392-1393 w Wielkim Księstwie Litewskim. Zapiski Historyczne, 2020, vol. 85, no. 3, pp. 71-104. DOI: 10.15762/ZH.2020.27. (In Polish)

65. Prochaska A. Archiwum Królestwa w Moskwie. Ateneum. 1888, vol. 51, yearbook 13, vol. 3, no. 2, pp. 358-366. (In Polish)

66. Prochaska A. Z Witoldowych dziejów. Przegląd Historyczny, 1912, vol. 15, no. 3, pp. 259-270. (In Polish)

67. Rachunki dworu króla Władysława Jagietly i królowej Jadwigi z lat 1388 do 1420. Piekosiński F. (ed.). Kraków: Nakładem Akademii Umiejętności, 1896. viii + $616+2$ p. (In Latin and Polish)

68. Rachunki królewskie z lat 1393-1395 i 1412. Rachunki podrzęctwa krakowskiego. Rachunki stacji nowosadeckiej. Wajs H. (ed.). Warszawa: "DiG", 1993. 4 + ix + 1 + 180 p. (In Latin and Polish) 
69. Scriptores rerum Prussicarum. Die Geschichtsquellen der preussischen Vorzeit bis zum Untergange der Ordensherrschaft. Hirsch Th. von, Töppen M., Strehlke E. (eds). Leipzig: Verlag von S. Hirzel, 1863, vol. 2. ii + 866 p. (In German and Latin)

70. Siemieński J. Rewindykacja archiwów koronnych. Przygotowanie naukowe i wyniki. Archeion. Warszawa: Wydawnictwo Archiwów Państwowych, 1927, vol. 1, pp. 33-60. (In Polish)

71. Sułkowska-Kurasiowa I. Dokumenty królewskie i ich funkcja w państwie polskim za Andegawenów i pierwszych Jagiellonów (1370-1444). Warszawa; Łódź: Państwowe Wydawnictwo Naukowe (Oddział), 1977. $286+8$ p. (In Polish)

72. Szweda A. Organizacja i technika dyplomacji polskiej w stosunkach z zakonem krzyżackim $w$ Prusach $w$ latach 1386-1454. Toruń: Wydawnictwo Naukowe Uniwersytetu Mikołaja Kopernika, 2009. 465 p. (In Polish)

73. Urzędnicy województwa ruskiego XIV-XVIII wieku (ziemie halicka, lwowska, przemyska, sanocka): Spisy. Przyboś K. (ed.). Wrocław i in.: Zakład Narodowy im. Ossolińskich - Wydawnictwo PAN, 1987. 415 p. (In Polish)

74. Wajs H. Rejestry podskarbiego Hinczki z lat 1393-1395 (bruliony a czystopis). Archeion. Warszawa: Naczelna Dyrekcja Archiwów Państwowych, 1993, vol. 91, pp. 4560. (In Polish)

75. Wigand von Marburg. Nowa kronika pruska. Zonenberg S., Kwiatkowski K. (eds). Torun: Towarzystwo Naukowe w Toruniu, 2017. $665+1$ p. (In Polish and Latin)

About the author: Sergey V. Polekhov - Cand. Sci. (History), Senior Research Fellow, School of Advanced Studies in the Humanities, Institute of Social Sciences of the Russian Presidential Academy of National Economy and Public Administration (82, Vernadsky Avenue, Moscow 119606, Russian Federation); ORCID: 0000-0001-7866-7663. E-mail: sergey.polekhov@gmail.com. 


\title{
БУЛГАРСКИЕ И ЗОЛОТООРДЫНСКИЕ БОГОСЛОВЫ И БОГОСЛОВСКИЕ ИСТОЧНИКИ ЧЕРЕЗ ПРИЗМУ «МУСТАФАД АЛ-АХБАР...» Ш. МАРДЖАНИ
}

\author{
P.К. Адыгамов ${ }^{1,2}$ \\ ${ }^{1}$ Институт истории им. Ш. Марджани АН РТ \\ Казань, Российская Федерация \\ abu_muhammad@mail.ru
}

«Мустафад ал-ахбар...» является одним из наиболее ранних и важных трудов по истории булгар и татар. Оценивая этот источник, можно по праву сказать, что он является первой попыткой научного описания и анализа истории булгар и татар. Для достижения поставленной задачи Ш. Марджани использовал большой массив различных источников, среди которых особое место занимают богословские источники. Раскрывая религиозную жизнь, ученый использовал в основном письменные источники. Однако он не ограничивался лишь их цитированием: изложение сопровождается анализом информации на достоверность, автор сопоставляет факты, сравнивает их, и делает соответствующие выводы относительно биографий богословов, а также содержания их трудов.

Целью исследования: является выявление названий богословских трудов и имен их авторов в первом томе упомянутого труда Ш. Марджани.

Материаль исследования: источниковую базу исследования составил первый том «Мустафад ал-ахбар...» Ш. Марджани, а также справочные труды мусульманских биографов. В ходе исследования были использованы методы анализа и синтеза, а также историко-сравнительный метод.

Результаты исследования: в результате нашего исследования были установлены названия богословских трактатов, упомянутых в первом томе «Мустафад алахбар...», имена их авторов, годы смерти, а также содержание произведений. Изучение персоналий богословов и их трудов позволило разделить их на булгарский и золотоордынский период. Однако следует отметить, что Ш. Марджани частично выходит за рамки упомянутых периодов и упоминает некоторых богословов, живших после завоевания Казанского ханства.

Новизна исследования: в рамках данного исследования впервые были выделены названия и тематика богословских трудов, упомянутых в первом томе «Мустафад алахбар...». Также были установлены имена их авторов, а сами труды разделены по историческому принципу на труды булгарского и золотоордынского периодов.

Ключевые слова: Ш. Марджани, Мустафад ал-ахбар, история богословия у татар, история булгар, история татар, богословские источники, богословы

Для цитирования: Адыгамов Р.К. Булгарские и золотоордынские богословы и богословские источники через призму «Мустафад ал-ахбар...» Ш. Марджани // Золотоордынское обозрение. 2021. Т. 9, № 2. C. 336-350. DOI: 10.22378/2313-6197.2021-92.336-350 


\title{
THE BULGAR AND GOLDEN HORDE'S THEOLOGIANS AND THEOLOGICAL SOURCES THROUGH THE PRISM OF SH. MARJANI'S “MUSTAFAD AL-AKHBAR...”
}

\author{
R.K. Adygamov ${ }^{1,2}$ \\ ${ }^{I}$ Marjani Institute of History of Tatarstan Academy of Sciences \\ Kazan, Russian Federation
}

\begin{abstract}
Research objectives: The "Mustafad al-akhbar..." is one of the earliest and most important works on the history of the Bulgars and their descendants - the Tatars. After evaluating this source, we can rightly say that it is the first attempt at a scholarly description and analysis of the history of the Bulgars and Tatars. To achieve this purpose, Sh. Marjani used a large array of different sources, among which a special place was occupied by theological sources. In revealing religious life, the theologian used mainly written sources, but he did not limit himself to quoting them. The presentation of these texts is accompanied by Sh. Marjnani's analysis of the information's reliability. The author compares the facts and makes reasonable conclusions about the biographies of theologians, as well as the content of their works.

The purpose of the study is to identify the authors' names and the titles of their theological works that Sh. Marjani used in the first volume of the mentioned work.

Research materials: The source basis of the study was the first volume of the "Mustafad al-akhbar..." by Sh. Marjani, as well as reference works by Muslim biographers. Throughout the study, the author used the methods of analysis and synthesis, as well as the historical and comparative method.

Research results: This study established the titles of the theological treatises to which Sh. Marjani referred in the first volume of the "Mustafad al-akhbar...", their content, the names of their authors, and years of their deaths. The study of the personalities of theologians and their works has allowed for a division of them into respective Bulgar and Golden Horde periods. However, it should be noted that Sh. Marjani partly goes beyond these periods and mentions some theologians who lived after the conquest of the Kazan Khanate in 1552.

Research novelty: The author described, for the first time ever, the titles and topics of theological works mentioned in the first volume of the "Mustafad al-akhbar...". Also, he identified the names of their authors and divided the works according to a historical principle into the works of the Bulgar and Golden Horde periods.
\end{abstract}

Keywords: Sh. Marjani, Mustafad al-Akhbar, history of theology among Tatars, history of the Bulgars, history of Tatars, theological sources, theologians

For citation: Adygamov R.K. The Bulgar and Golden Horde's Theologians and Theological Sources through the Prism of Sh. Marjani's "Mustafad al-akhbar...". Zolotoordynskoe obozrenie=Golden Horde Review. 2021, vol. 9, no. 2, pp. 336-350. DOI: 10.22378/2313-6197.2021-9-2.336-350

\section{Введение}

В своем историческом труде «Мустафад ал-ахбар фи ахвали Казан ва Булгар» («Полезные вести о состоянии Казани и Булгара») Ш. Марджани наряду с историческим повествованием и анализом затрагивает широкий круг научных вопросов. Среди них можно выделить вопросы истории, географии, этнонимов, богословия и др. В ходе повествования богослов и историк приводит «Раздел о наследии и ученых Булгарии». В данном разделе он приводит не только их имена, годы жизни и краткие биографии, перечисляет их труды, но также дает 
им критическую оценку. Помимо биографических данных и трудов, ученый также углубляется в некоторые богословские вопросы. Анализ проблематики данного раздела обусловил актуальность его более детального изучения. Особую важность он приобретает не только в связи с процессами этноконфессионального возрождения, начавшимися в конце XX в., но также с необходимостью выявления и переосмысления наследия татарского духовенства в частности и российских мусульманских богословов в целом.

Возрождение институтов мусульманского социума и системы образования обострили вопросы поиска вектора развития мусульманской уммы России. Распространение различных идеологических установок, проникших в страну в 90-е годы XX в. привело не только к расколу в рядах мусульман, но также несло угрозу стабильности общества. В этой связи все большую актуальность приобретала задача выявления многовековой мусульманской богословской традиции, имеющей опыт выстраивания миролюбивых взаимоотношений как внутри конфессии, так и с представителями иных религий.

Это в свою очередь пробуждает особый интерес к биографическим и историческим трудам российских мусульманских богословов. В частности, к таким источникам как «Мустафад ал-ахбар...», «Талфик ал-ахбар...», «Асар» и пр.

Цель данного исследования выявить и описать персоналии богословов и богословские труды булгарского и золотоордынского периодов.

Общий обзор источников, использованных при написании «Мустафад алахбар...» можно обнаружить в статьях И.М. Миргалеева [6, с. 102-109; 7 , с. 179-195; 8, с. 183], М.А. Усманова [4, с. 17]. Более подробный анализ и описание представлены в диссертации Р.Т. Юзмухаметова [13]. Также описание и классификация источников данного труда была представлена в исследовании автора данной статьи [1, с. 674-686]. Однако упомянутые исследования в основном анализируют источники с исторической и структурнолингвистической точки зрения. Что же касается выявления и описания личностей богословов и богословских источников, упомянутых в «Мустафад алхабар...», то оно проводится впервые.

\section{Богословы и источники булгарского периода}

Первым среди богословов булгарского периода Ш. Марджани упомянул Йа“куба ибн Ну“мана ал-Булгари'. Автор сообщает о том, что он написал книгу, посвященную истории Булгара, но она была утрачена. По его данным, в ее поисках были заинтересованы даже европейские историки, но в отличие от записок Ибн Фадлана ${ }^{2}$, она не была обнаружена. О самом богослове информация довольно скудная, со ссылкой на Абу Хамида ал-Андалуси ${ }^{3}$,

${ }^{1}$ Был судьёй Булгара. Абу Хамид ал-Андалуси упоминает о встрече с этим человеком в 530 г. (1135 г.) во время посещения Булгара.

${ }^{2}$ Ахмад ибн ал-'Аббас ибн Рашид ибн Хаммад ал-Багдади (предположительно 877960 [1472-1552]). Исламский учёный и известный путешественник. Один из немногих арабских путешественников, лично побывавших в Восточной Европе. В 921-922 годах в качестве секретаря посольства аббасидского халифа ал-Муктадира посетил Волжскую Булгарию. В своём отчёте «Рисаля», написанном в виде путёвых заметок, оставил уникальные описания быта и политических отношений огузов, башкир, булгар, русов и хазар.

${ }^{3}$ Абу Хамид ал-Андалуси (473-565 [1080-1170]) Абу 'Абд Аллах Мухаммад ибн 'Абд ар-Рахим ал-Мазини ал-Калиси ал-Гарнати ал-Андалуси. Исламский правовед и 
Марджани сообщает об их встрече в 529 г. (1134 г.) в Булгаре. Также по информации Закарийи ибн Мухаммада ал-Казвини ${ }^{4}$, этот человек был учеником имама ал-харамайн Абу ал-Ма'али 'Абд ал-Малика ибн 'Абдуллы алДжувайни и умер в 559 г. (1163 г.) [5, с. 78]. Кроме упомянутых фактов, М. Рамзи еще указывает на то, что на исторический труд Йа“куба ибн Ну“мана ссылался Абу Хамид ал-Гарнати [9, с. 318].

Следующий богослов - Абу ал-‘Ала Хамид ибн Идрис ал-Булгари [9, c. 324$]^{6}$. Марджани сообщает, что он был кадием, жил в 500 г. (1106 г.). А также, со ссылкой на «Зухрат ар-рийад» ${ }^{7}$ Сулеймана ибн Дауда ас-Саксини $[12]^{8}$, приводит несколько цепочек хадисов с упоминанием этого человека. В этих цепочках присутствуют такие передатчики как: Абу ал-Му“ин Маймун ибн Мухаммад ибн Му“тамад ал-Макхули ан-Насафи', 'Абдулла ибн Мас'уд ${ }^{10}$, Хамид ибн Идрис'11, Абу Бакр Мухаммад ибн 'Абдулла асСархакти $^{12}$, Ибн 'Умара'를 Абу Ибрахим Исма'ил ибн Мухаммад ибн ал-

арабский путешественник. Автор известной книги «Тухфа ал-албаб ва нухба ал-и“джаб», в которой он собрал свои заметки, написанные во время путешествий в разные страны, в том числе в Волжскую Булгарию.

${ }^{4}$ Закария ибн Мухаммад ал-Казвини: (605-682 (1208-1283)) Абу 'Абд Аллах Закария ибн Мухаммад ибн Махмуд ал-Казвини. Известный арабский учёный в области астрономии, физики, геологии, географии, истории, психологии, медицины, фармацевтики, химии, ботаники и зоологии. Автор знаменитой книги «'Аджа’иб ал-махлукат ва гара'иб ал-мауджудат», в которой он описывает планеты, звёзды, минералы, растения и животный мир.

${ }^{5}$ Абу ал-Ма'али ал-Джувайни: (419-478 [1028-1085]) Имам ал-Харамайн Абу алМа'али 'Абд ал-Малик ибн 'Абд Аллах ибн Йусуф ибн Мухаммад ибн 'Абд Аллах ибн Хайва ал-Джувайни. Выдающийся шафиитский правовед и аш'аритский мутакаллим. Учитель Абу Хамида ал-Газали. Является автором многих книг по исламскому праву, усул ал-фикху и науке - калам.

${ }^{6}$ Абу ал-“Ала Хамид ибн Идрис ал-Булгари (?-?). Об этой личности почти ничего неизвестно. Жил в 600 г. (1203 г.).

${ }^{7}$ Автор - Сулейман ибн Дауд ас-Саксини. Книга состоит из 67 бесед. Ее полное название - «Зухрат ар-рийад ва нузхат ал-кулуб ал-мирад». В каждой главе этой книги приводится какой-либо хадис и, в соответствии с ним, наставления и советы. Рукопись данной книги была обнаружена С.Т. Рахимовым. Библиотека «Сулеймания», фонд «Тырновалы», номер 968. Сулейман бин Дауд ас-Саксини. Дата рукописи - 1329 г. Второй список хранится в Мешхеде в центре «Остан» под номером 1341. Ее копия была передана в Архивное управление Республики Татарстан.

${ }^{8}$ Ученик Абу-л-“Аля Хамида ибн Идриса ал-Булгари (первая половина XII в.). В своих дидактических и художественных произведениях подробно излагает проповеди учителя. Труды Сулеймана ибн Дауда вошли во многие источники, цитировали их многие ученые и богословы (первая пол. XII в. и до XX в.). Также известно, что его перу принадлежит еще одно сочинение - «ат-Тафсир фи 'илм ат-тазкир» («Разъяснение науки о напоминании»).

${ }^{9}$ Исламский богослов, правовед ханафитского мазхаба (436-508 [1046-1114 гг.]).

${ }^{10}$ Один из сподвижников пророка Мухаммада, считался одним из наиболее известных знатоков религии.

${ }^{11}$ (?-1105), булгарский богослов, философ, кади. Автор религиозных и философских сочинений.

${ }^{12}$ Абу Бакр Мухаммад ибн 'Абд Аллах ас-Сархакти (умер в 518 г. [1124 г.]).

${ }^{13}$ Один из известнейших сподвижников, сын 'Умара ибн ал-Хаттаба. 
Хасан ал-Хусайний ${ }^{14}$ ' 'Имад ад-Дин Абу Бакр Мухаммад ибн ал-Хасан ибн Мансур ан-Насафи ${ }^{15}$, Абу Бакр Мухаммад ибн 'Умар ал-Баззар ${ }^{16}$, Абу Зарра ${ }^{17}$, ал-Хаджадж Абу Бакр Мухаммад бин 'Али ибн ал-Фадл ал-Баздигри ${ }^{18}$.

При этом видно, что Ш. Марджани довольно глубоко владел информацией о передатчиках хадисов. В частности он указывает: «Нуждающийся (в помощи Аллаха - A.P.) автор этих строк сказал: “Абу ал-Му“ин ан-Насафи ${ }^{19}$ умер в 508 г. (1114 г.) в Насафе, Абу Бакр Мухаммад ибн Хасан ибн Мансур ан-Насафи ал-Гуайдани умер в 505 г. (1111 г.) в Бухаре"» [5, с. 79]. Второй, видимо, является малоизвестным передатчиком, так как информация о нем не была обнаружена.

Также Марджани поясняет: «Абу Бакр Мухаммад ибн 'Абдулла асСархакти умер в 518 г. (1124 г.) и был родственником Абу Ибрахима Исма'ила ибн Мухаммада ибн ал-Хасана Абу ал-Йусра ал-Баздави ${ }^{20}$ и Абу алМу'ина ан-Насафи. От него передавали Ахмад бин Мухаммад ал-Хаками, Абу Бакр Мухаммад бин 'Умар ал-Базари ${ }^{21}$, Абу Бакр Мухаммад ибн 'Али ибн ал-Фадл ан-Найсабури ал-Буздигари ${ }^{22}$. Все они умерли в пределах пятисотых годов (1106 г.)» [5, с. 80]. Таким образом, мы можем заключить, что Ш. Марджани прибегает к классической богословской методологии проверки аутентичности текста на основе анализа цепочки его передатчиков. В результате анализа и выявления возможности встречи передатчиков различных поколений богослов приходит к выводу о целостности цепочки, на основе чего делает вывод об аутентичности содержания самого предания.

Однако вызывает вопрос тот факт что, упомянув Сулеймана ибн Дауда ас-Саксини в качестве ученика Абу ал-'Ала Хамида ал-Булгари, Ш. Марджани не говорит о нем как о богослове булгарского периода. Как известно, автор «Зухрат ар-рийад...» также был булгарским богословом. Вероятно, Ш. Марджани посчитал достаточным описание его труда, хотя оно преподносится лишь как иллюстрация к личности Сулеймана ибн Дауда ас-Саксини. В

${ }^{14}$ Абу Ибрахим Исма'ил ибн Мухаммад ибн ал-Хасан ал-Хусайни: об этой личности почти ничего неизвестно. Жил в V веке хиджры (XII в.). Упоминается в некоторых биографических справочниках по ханафитским учёным.

${ }^{15}$ Информация не найдена.

${ }^{16}$ Информация не найдена.

${ }^{17}$ Сподвижник пророка Мухаммада.

${ }^{18}$ Информация не найдена.

${ }^{19}$ Абу Ал-Му“ин Ан-Насафи (418/438-508 гг. [1027/1038-1114 гг.]): Абу Ал-Му“ин Маймун ибн Мухаммад ибн Мухаммад ибн Му“тамад ибн Мухаммад ибн Макхуль ибн Ал-Фадл Ан-Насафи Ал-Макхули. Выдающийся матуридитский мутакаллим и ханафитский правовед. Является автором книги «Табсыра ал-адилля фи усуль ад-дин», которая представляет собой важнейшую энциклопедию по матуридитскому каламу. Также написал ряд других книг по матуридитскому каламу и ханафитскому праву. Как один из самых ревностных последователей имама Ал-Матуриди, он сыграл ключевую роль в распространении матуридитского калама.

${ }^{20}$ Абу ал-Йуср ал-Баздави (421-493 [1030-1100 гг.]): Абу ал-Йуср Мухаммад ибн Мухаммад ибн ал-Хусейн ибн 'Абд ал-Карим ибн Муса ибн Муджахид ан-Насафи. Был судьёй Самарканда. Известный ханафитский правовед и матуридитский мутакаллим. Написал ряд книг по праву и 'акыде. В частности, является автором известной книги по матуридитскому каламу «Усул ад-дин».

${ }_{21}^{22}$ Информация не найдена.

${ }^{22}$ Информация не найдена. 
известном справочнике «Кашф аз-зунун» сообщается, что изначально труд был написан на персидском языке и назывался «Бахджат ал-анвар мин хафийат ал-асрар», впоследствии автор перевел его на арабский язык и озаглавил «Нузхат кулуб ал-мирад», а позднее название было дополнено фразой «Зухрат ар-рийад» [10, с. 364]. Здесь же он упомянут как ас-Сувари, что может указывать на его происхождение из Сувара, а не Саксина.

Более подробно Марджани пишет о ходже Ахмаде ал-Бургари [9, c. 323-324]. В том числе приводит различные написания нисбы «Бургари» и «Булгари». Также известно, что этот человек был учителем и наставником султана Махмуда ибн Сабактакина ал-Газнави ${ }^{23}$. Его имя упомянул 'Ала' ад-Дин 'Абд ал-'Азиз ибн Ахмад ал-Маймарги ${ }^{24}$ в своем комментарии «Усул фахр ал-ислам» ${ }^{25}$, в комментариях к «Кашф ал-кабир» и «Усул алхусами» $^{26}$. Также одна из его точек зрения на вопрос о разводе упомянута в «Фаваид ал-давахир» со ссылкой на «Кунья» ${ }^{27}$. А Мулла Абу ал-Макарим ${ }^{28}$ в комментарии к «Мухтасар ал-викайа» ${ }^{29}$ ссылается на его книгу «Фаваид ал-Бургари» [5, с. 80].

Подытоживая характеристику этого человека, великий татарский богослов и историк указывал: «В целом об этом человеке можно сказать, что он был ученым, факихом, знатоком основ, глубокознающим, уважаемым, умелым человеком. Он был современником Шамс ал-А'имма ас-Сарахси ${ }^{30}$, Фахр ал-Ислама ал-Баздави ${ }^{31}$, Шейх ал-Ислама Хувахар заде ${ }^{32}$, и был ученым их уровня» [5, с. 81$]$.

${ }^{23}$ Махмуд ибн Сабактакин Ал-Газнави (971-1030): Абу ал-Касим Махмуд ибн Сабактакин ал-Газнави. Величайший султан Газневидского султаната. Правил своей страной в 998-1030 г. Ряд авторов считают его «истинным основателем» Газневидского султаната. Во время его правления государство достигло наивысшего зенита в военно-политической сфере. Покровительствовал учёным и суфиям. Один из самых крупнейших завоевателей в истории ислама. Совершил множество завоевательных походов, особенно в направлении Индии.

24 'Аля ад-Дин 'Абд ал-“Азиз ибн Ахмад (?-730 г. [1330 г.]): 'Аля Ад-Дин 'Абд Ал'Азиз ибн Ахмад ибн Мухаммад Ал-Бухари Ал-Ханафи. Ханафитский правовед. Ему принадлежит книга по усул ал-фикху «Шарх усул ал-баздави».

${ }^{25}$ Автор - Абу ал-Хасан Фахр ал-Ислам ал-Баздави. Известная книга по усул алфикху в соответствии с ханафитской методологией.

${ }^{26}$ Иное название: «Ал-Мунтахаб фи усул ал-мазхаб». Также известен под названием «Ал-Мунтахаб ал-хусами». Автор - Мухаммад ибн Мухаммад ибн 'Умар Хусам ад-Дин ал-Ахсикати. Известная книга по ханафитскому усул ал-фикху.

${ }^{27}$ Полное название: «Кунья ал-минйа 'аля мазхаб Аби Ханифа». Автор - Мухтар ибн Махмуд ибн Мухаммад аз-Захиди ал-Ханафи. Книга по ханафитскому праву. Она не пользуется авторитетом в ханафитском мазхабе.

${ }^{28}$ Информация не найдена.

${ }^{29}$ Полное название: «Мухтасар ал-викая фи масаил ал-хидая». Автор - 'Убайд Аллах ибн Мас'уд ал-Махбуби. Известная книга по ханафитскому праву.

${ }^{30}$ Шамс ал-А’имма ас-Сарахси (400-483 г. [1009-1090 г.]): Шамс Ал-А‘имма Абу Бакр Мухаммад ибн Ахмад ибн Абу Сахль Ас-Сарахси. Авторитетный ханафитский правовед. Автор ряда известных книг по ханафитскому праву и усул ал-фикху. Является автором книги «Ал-Мабсут», которая представляет собой многотомную и авторитетную энциклопедию по ханафитскому праву.

${ }^{31}$ Абу ал-Хасан 'Али ибн Мухаммад ал-Баздави (?-482 г. [1089 г.]): Абу ал-Хасан Фахр ал-Ислам 'Али ибн Мухаммад ибн ал-Хусейн ибн 'Абд ал-Карим ибн Муса ибн 'Иса ибн Муджахид ал-Баздави. Крупный ханафитский правовед и специалист по усул ал- 
Следует отметить, что информация относительно булгарского происхождения ходжи Ахмада ал-Булгари не является однозначно достоверной. Сам Ш. Марджани приводит его нисбу как «Бургари» или «Баргари». Такой вариант прочтения дает основания предполагать, что этот человек мог быть выходцем из деревни Баргар, расположенной в Саганийане на юге Центральной Азии. В частности, деревня с одноименным названием в настоящее время находится на севере Индии в штате Уттар Прадеш. Соответственно, второй вариант понимания исключает его из числа булгарских богословов.

Далее - Ахмад ибн 'Абдуллах ал-Кирмани'33. Он был учеником 'Абд алАввала бин 'Али ал-Фергани ${ }^{34}$, Хафиз ад-Дина ибн ал-Баззаз, Шараф ад-Дина ибн Камал ад-Дин ал-Крыми ${ }^{35}$. Его перу принадлежат субкомментарии к таким книгам как «Талвих», «Шарх 'акаид ан-Насафийа» ${ }^{36}$. Также его учеником был Йусуф ибн Джунайд ат-Тукати ${ }^{37}$, известный как Челяби.

\section{Богословие в Золотой Орде}

Среди богословов золотоордынского периода Ш. Марджани первым упомянул Бурхан ад-Дина Ибрахима ибн Хидра ал-Булгари ал-Ханафи [9, c. 326$]^{38}$. Он указывает, что этот человек был автором книги «Усул алХусами», которая была завершена, в третий день месяца раби“ ал-аввал 751 г. (1350 г.). О самой рукописи богослов пишет: «Эта большая, хорошо сохранившаяся рукопись, с четким почерком, похожим на почерки, распространенные в Алеппо, Дамаске и других городах Шама. Она уже издавна находится в руках, автора ${ }^{39}$, нуждающегося (в помощи Аллаха - A.P.)» [5, с. 82].

фикху. Он написал ряд книг по ханафитскому праву и известный трактат по усул алфикху «Усул ал-баздави».

32 Шейх ал-Ислам Хувахар Заде (?-483 г. [1090 г.]): Мухаммад ибн ал-Хусейн ибн Мухаммад ибн ал-Хасан ал-Бухари Бабакр Хувахар Заде. Ханафитский правовед. Сообщается, что он написал трактат по ханафитскому мазхабу под названием «Мабсут»; однако данная книга утеряна.

33 Ахмад ибн 'Абд Аллах ал-Кирмани (352-412 гг. [963-1021 гг.]): Хамид ад-Дин Ахмад ибн 'Абд Аллах ал-Кирмани. Известный философ исмаилитской секты. Ему принадлежит большая роль в систематизации философской системы исмаилизма. Написал ряд книг по исмаилитской идеологии.

${ }^{34}$ Информация не найдена.

${ }^{35}$ Шараф Ад-Дин ибн Камал Ал-Крыми (?-?). Об этой личности мало информации. Был исламским правоведом, предположительно, ханафитским. Сначала жил в Крыму, потом переехал в Османскую империю. Сообщается, что он написал комментарий к известной книге по усул ал-фикху «Ал-Манар».

${ }^{36}$ Автор - Са'д ад-Дин ат-Тафтазани. Одна из самых известных и авторитетных книг по матуридитской акыде.

37 Йусуф ибн Джунайд ат-Тукати (?-902/5 г. [1496/9 г.]): Йусуф ибн Джунайд атТукати Ар-Руми Джаляби. Ханафитский правовед. Написал ряд книг по ханафитскому праву и акыде. В частности, его перу принадлежит субкомментарий на известный трактат по ханафитскому праву «Ал-Викая» и сокращённая версия известного сборника ханафитских фетв «Фатава Кады Хан».

38 Бурхан ад-Дин Ибрахим ибн Хидр ал-Булгари ал-Ханафи (?-?). Об этой личности почти ничего неизвестно. Был жив в 751 г.

${ }^{39}$ Ш. Марджани имеет ввиду себя $-A . P$. 
Следующий богослов этого периода, упомянутый у Ш. Марджани - Абу Мухаммад Садр ибн 'Ала ад-Дин ал-Булгари ${ }^{40}$. Марджани сообщает, что одним из его учеников был Тадж ад-Дин Ибрахим ибн Мухаммад ${ }^{41}$, получивший от него иджазу в конце рукописи книги «Усул», принадлежащей перу Фахр ал-Ислама ${ }^{42}$. Информации об этом человеке довольно мало. М. Рамзи сообщает о его иджазе, из которой можно примерно датировать период, когда он жил четырнадцатым веком. В частности, иджаза была дана 22 шаввала 766 г. (11 июля 1365 г.) [9, с. 327].

Далее следует известный суфий ходжа Хасан ибн 'Умар ал-Булгари ${ }^{43}$, который был мюридом шейха Са'д ад-Дина ал-Хамави ${ }^{44}$. Марджани указывает, что он был родом из города Канджа в Азербайджане, но благодаря тому, что долгое время прожил в Булгаре, стал известен как «булгари». В то же время есть разногласия по месту захоронения этого богослова. По одной из версий он был захоронен в Бухаре, и место захоронения именуется как Ходжа Булгари. По другой версии он умер и, соответственно, был похоронен в Тебризе в 677 г. (1278 г.). Следует отметить, что М. Рамзи указывает иную дату смерти - 22 раби“ ал-аввала 698 г. Он же указывает, что по иной версии он происходил не из Азербайджана, а деревни Хасан шейх, расположенной северозападнее Булгара $[9, \text { с. 329] }]^{45}$.

Следующий - Бурхан ад-Дин Ибрахим ибн Йусуф ал-Булгари [9, c. 237$]^{46}$. В «Кашф аз-зунун» ${ }^{47}$ указано, что он был автором книги «Шарх адаб ac-сахаиф» [11, с. 40]. Также сказано: «Для книги “Фусул ан-насафи”,48 был написан комментарий Бурхан ад-Дином ал-Булгари».

Далее [5, с. 85] - известный ханафитский богослов Наджм ад-Дин Абу арРаджа' Мухтар ибн Махмуд ибн Мухаммад ал-Казани ал-Ханафи ${ }^{49}$, известный как аз-Захиди. Он является автором «ал-Кинйа» и комментария к «Мухтасар

${ }^{40}$ Абу Мухаммад Садр ал-Булгари (?-?): Абу Мухаммад Садр ад-Дин ибн 'Ала адДин ал-Булгари. Об этой личности почти ничего неизвестно.

41 'Исам Ад-Дин Ибрахим ибн Мухаммад ал-Исфараини (?-951 г. [1544 г.]): 'Исам ад-Дин Ибрахим ибн Мухаммад ал-Исфараини. Ханафитсий правовед и матуридитский мутакаллим. Написал ряд книг по арабской морфологии и каламу.

${ }^{42}$ Информация не найдена.

${ }^{43}$ Хасан ибн 'Умар ал-Булгари (?-678 г. [1279 г.]): Хасан Салах ад-Дин ибн 'Умар алБулгари.

${ }_{44}$ Мухаммад ибн ал-Му’аййад ибн Абу Бакр Абу ал-Хасан ибн Мухаммад ибн Хамавийа, один из мюридов Наджм ад-Дина ал-Кубра (ум. 650 [1252 г.]). См. ал-Джами А. Нафахат ал-унс мин хадарат ал-кудс. Бейрут: Дар ал-кутуб ал-“илмийа, 2003. Т. 2, С. 584.

45 Также он указывает, что этот богослов много путешествовал, в разное время жил в Булгаре, Бухаре, Кирмане и Тибризе, где умер и был похоронен. Многие ученые стали его мюридами.

${ }^{46}$ Бурхан ад-Дин Ибрахим ибн Йусуф ал-Булгари (?-?). Об этой личности почти ничего неизвестно. Его упоминает ар-Рамзи.

47 Автор - Хаджи Халифа. В этой энциклопедической книге упоминаются арабские, персидские и турецкие трактаты и их авторы.

${ }^{48}$ Полное название: «Ал-фусул фи 'ильм ал-джадл». Автор - Бурхан ад-Дин Мухаммад ибн Мухаммад ибн Мухаммад ан-Насафи ал-Ханафи. В книге затрагиваются вопросы усул ал-фикха, методов использования логических аргументов и т.п.

49 Мухтар ибн Махмуд ибн Мухаммад Абу ар-Раджа Наджм ад-Дин аз-Захиди алГазмини (ум. 658 г. [1260 г.]). Один из крупнейших ханафитских факихов родом из Газмина на территории Хорезма. Посетил Багдад и Византию. 
ал-Кудури». Его наставниками по фикху были Садид ибн Мухаммад алХаййати ${ }^{50}$ и Бурхан ал-А'имма Мухаммад бин 'Абд ал-Карим ${ }^{51}$, по каламу от Йусуф ибн Абу Бакр ас-Сакаки ${ }^{52}$. Известен тем, что в честь хана Береке трактат назвал свой трактат «Рисала-и насырийа». Умер в 688 г. (1289 г.).

О следующем богослове известно лишь имя - Ахмад ибн Махмуд алДжунди ${ }^{53}$, а также наименование его труда - комментарий к «Мисбах» ${ }^{54}$, принадлежащему перу Матрази, и названный «Макалид» [5, с. 85]. Ш. Марджани указывает, что часть книги была написана в 751 г. (1350 г.) [5, с. 85], а, следовательно, автор относится к ученым XIV века. Место его рождения не известно, поэтому к ученым Поволжья он мог быть причислен лишь в том случае, если некоторое время жил в Булгаре или Сарае, что также не удалось установить.

Далее следует Кутб ад-Дин Мухаммад ибн Мухаммад ар-Рази ашШафи' ий ${ }^{55}$. Марджани сам указывает, что его происхождение связывают с городом Рейем [5, с. 86], а, следовательно, и его включение в список богословов Булгарии вызывает вопрос. Известно, что этот человек был автором «Китаб ал-мухакамат» ${ }^{56}$, «ар-Рисала ал-ма“мула» ${ }^{57}$, комментатором «ал-Мата$л^{6} »^{58}$, «аш-Шамсиййа» ${ }^{59}$, «ал-Хави ас-сагир» ${ }^{60}$, посвященных проблемам шафиитского фикха.

За ним следует Минхадж ад-Дин Ибрахим ибн Сулейман ас-Сараи. Этот человек известен тем, что его наставник Рашид ад-Дин Исма'ил ибн Махмуд ибн Мухаммад ал-Кардарий был автором книги «Фаваид ал-маса'ил аддарурийа» ${ }^{61}$, а он скомпоновал эту книгу и дополнил ее, в результате чего она превратилась в комментарий к «Фара'ид ал-'усманийа» ${ }^{62}$, названный «Мафа-

${ }^{50}$ Садид ибн Мухаммад ал-Хаййати (?-?). Информация не обнаружена. Он упоминается в некоторых биографических справочниках ханафитских ученых.

${ }^{51}$ Бурхан ал-А’имма Мухаммад ибн 'Абд ал-Карим: информация не обнаружена. Он упоминается в некоторых биографических справочниках ханафитских ученых.

${ }^{52}$ Йусуф ибн Абу Бакр ас-Саккаки (555-626 гг. [1160-1229 гг.]): Сирадж ад-Дин Абу Йа‘ куб Йусуф ибн Абу Бакр ибн Мухаммад ибн 'Али ас-Саккаки ал-Хаваризми. Написал ряд книг по языковым наукам.

${ }^{53}$ Ахмад ибн Махмуд ал-Джунди (?-?). Об этой личности почти ничего неизвестно. Он упоминается в некоторых биографических справочниках ханафитских ученых. Является автором комментария на книгу по грамматике «Ал-Мисбах», составленную алМатрази.

${ }_{54}$ Автор - Абу ал-Фатх Насыр ибн Абу ал-Макарим ал-Матрази. Книга по арабской грамматике.

${ }^{55}$ Кутб ад-Дин ар-Рази (694-766 гг. [1295-1365 гг.]): Кутб ад-Дин Абу 'Абд Аллах Мухаммад ибн Мухаммад ар-Рази ат-Тахтани. Написал ряд трудов в области логики и философии. В некоторых источниках сообщается, что он был шиитом-имамитом.

${ }^{56}$ Автор - Кутб ад-Дин ар-Рази. Книга посвящена проблемам логики.

${ }^{57}$ Автор - Кутб ад-Дин ар-Рази. Содержание книги неизвестно.

${ }^{58}$ Автор - Сирадж ад-Дин Махмуд ал-Армави. Книга по логике.

${ }^{59}$ Автор - Наджм ад-Дин 'Умар ибн 'Али ал-Казвини. Книга по логике.

${ }^{60}$ Автор - 'Абд ал-Гаффар ибн 'Абд ал-Карим ал-Казвини. Посвящена вопросам шафиитского права.

${ }^{61}$ Автор - Рашид ад-Дин Исма“ил ибн Махмуд ибн Мухаммад ал-Кардари. Содержание книги неизвестно.

${ }^{62}$ Автор - Рашид ад-Дин Исма“ил ибн Махмуд ибн Мухаммад ал-Кардари. Содержание книги неизвестно. 
тих ал-акфал» ${ }^{63}$. Известно, что эта книга была дописана им в Хорезме в 771 г. (1369 г.).

Следующий - Ахмад ибн Шамс ал-А’имма ас-Сараи. Информация об этом человеке практически отсутствует. Марджани, со ссылкой на Ибн 'Арабшаха, приводит следующую цитату: «Он повелитель слов арабского, персидского и тюркского языков. Он был очень удивительным человеком для своего времени. Даже Тамерлан пригласил его в Самарканд» [5, с. 86]. Из чего можно сделать вывод, что, скорее всего, он был языковедом.

Одним из наиболее известных богословов, упомянутых в «Мустафад...», является Са'д ад-Дин Мас'уд ибн 'Умар ал-Хорасани ан-Насаи аш-Шафи“и, известный как ат-Тафтазани ${ }^{64}$, автор комментария к «'Ака’ид ан-Насафи», а также многих других книг. Несмотря на известность богослова, вызывает вопрос о его причислении к ученым Булгарии. Нисба ат-Тафтазани указывает на то, что он происходил из деревни Тафтазан, находящейся в иранской провинции Северный Хорасан. Возможно, Ш. Марджани исходил из того, что он некоторое время проживал в Сарае, столице Золотой Орды, однако, следует помнить о его персидских корнях. В этой связи с классификацией татарского богослова можно не согласиться: вероятнее всего, она была связана с желанием придать больший вес булгарскому богословию.

О следующем богослове информации довольно мало. Камал ад-Дин алХуджанди ${ }^{65}$. Со ссылкой на неизвестного автора Сеида Ракима, Марджани приводит цитату: «Когда войско хана Токтамыша направлялось в Табриз, уважаемый шейх Камал ад-Дин находился в этом городе. Когда же город был захвачен, то по велению хана Токтамыша он был доставлен в столицу Дешт-и кипчака Сарай» [5, с. 87]. Видимо, появление этого ученого в Сарае и стало причиной включения в данный список.

Далее - Хафиз ад-Дин Мухаммад ибн Мухаммад ибн Шихаб ибн Йусуф ал-Хаваризми ал-Кардари ${ }^{66}$, известный как Ибн ал-Баззаз. Является известным ханафитским богословом. Он умер в возрасте 80 лет в 827 г. (1423 г.). Татарский богослов и история сообщают, что этот человек не только путеше-

${ }^{63}$ Автор - Рашид ад-Дин Исма'ил ибн Махмуд ибн Мухаммад ал-Кардари. Содержание книги неизвестно.

${ }^{64}$ Са'д ад-Дин ат-Тафтазани (722-792 гг. [1322-1390 гг.]): Са'д ад-Дин Абу Са‘ ид Мас'уд ибн 'Умар ибн Мухаммад ибн Абу Бакр ибн Мухаммад ибн ал-Гази ат-Тафтазани ас-Самарканди. Выдающийся суннитский мутакаллим и ханафито-шафиитский правовед. Издавал фетвы как по ханафитскому, так и по шафиитскому мазхабу. Автор множества трактатов по каламу, логике, усул ал-фикху, правилам арабского языка, исламскому праву, тафсиру. Автор знаменитой книги по суннитскому каламу «Шарх ал-'акаид аннасафиййа», которая считается одним из важнейших трактатов по преподаванию исламских убеждений. Он также написал книгу «Шарх ал-макасыд», которая представляет собой многотомную энциклопедию по каламу.

${ }^{65}$ Камал ад-Дин ал-Худжанди (1321-1400 гг.): Камал ад-Дин Мас'уд ибн ‘Абд Аллах ал-Худжанди. Поэт и суфий. Похоронен в городе Табриз.

${ }^{66}$ Хафиз ад-Дин ал-Баззази (?-827 г. [1424 г.]): Хафиз ад-Дин Мухаммад ибн Мухаммад ибн Шихаб ибн Йусуф ал-Кардари ал-Хаваризми ал-Баззази. Ханафитский правовед. Автор ряда трактатов по ханафитскому праву. В частности, его перу принадлежит известный сборник ханафитских фетв «Ал-Фатава ал-баззазиййа». 
ствовал по Булгарии, Крыму, Византии, но и долгое время прожил в Булгаре [5, с. 87]. Известен своим сборником фетв «Фатава Базазийа» ${ }^{67}$.

О следующем богослове - 'Исаме ибн ал-Малике ал-Маргинани - известно то, что он был сыном автора «ал-Хидайа» ${ }^{68}$. Он был факихом, ученым и поэтом. Марджани приравнивает его к Хафиз ад-Дину ибн ал-Баззазу и пишет о соперничестве между этими двумя учеными [5, с. 88].

Далее упоминается Шихаб ад-Дин Ахмад ибн Мухаммад ибн 'Абдуллах ал-Кураши ад-Димашки", известный как Ибн 'Арабшах. Как указывает татарский богослов и историк, он родился в Дамаске в 791 г. (1388 г.) и умер в 954 г. (1547 г.) [5, с. 88]. По всей видимости, либо сам Марджани допустил неточность, либо это является опечаткой. Известно, что Ибн 'Арабшах умер в 854 г. хиджры, что соответствует 1450 г. Он был факихом, знатоком литературы, поэтом, историком и этнографом, много путешествовал по Булгарии, Ираку, Хорасану, Византии, Мавераннахру и Хорезму. Его перу принадлежит книга «“Аджа' иб ал-макдур фи наваиб (фи ахбар) Таймур» ${ }^{70}$.

О следующем богослове - Мухаммаде ал-Булгари ${ }^{71}-$ известно только то, что он является автором небольшой книги наставлений и проповедей «Хазинат ал-“улама ва зинат ал-фукаха»[11, с. 704], содержащий хадисы и предания.

Среди богословов Казани и Булгара Ш. Марджани также приводит Касима ибн Ибрахима ал-Казани, известного как Шейх 'Азизан и который был мюридом Вали 'Азизана ал-Кухзари. Однако его нельзя отнести ни к булгарскому, ни к золотоордынскому периоду, так как известно, что он умер в 998 г. (1589 г.) в Кримне, деревне между Бухарой и Самаркандом [5, с. 83].

\section{Заключение}

Анализ содержания первого тома «Мустафад ал-ахбар...» позволил выявить, что в основном повествование имеет описательный характер, лишь при анализе некоторых вопросов исламского права автор прибегает к их содержательному анализу. В частности, останавливаясь на проблеме определения времени ночной молитвы в летнее время в Волго-Уральском регионе, автор использует труд Наджм ад-Дина аз-Захиди ${ }^{72}$, комментарий к известной хана-

${ }^{67}$ Автор - Хафиз ад-Дин Мухаммад ал-Хаваризми ал-Кардари. Известный сборник фетв ханафитского мазхаба.

${ }^{68}$ Автор - Бурхан ад-Дин Абу ал-Хасан 'Али ал-Маргинани. Известная книга по ханафитскому праву.

${ }^{69}$ Ибн 'Арабшах (791-854 гг. [1389-1450 гг.]): Шихаб ад-Дин Абу Мухаммад Ахмад ибн Мухаммад ибн 'Абд Аллах ибн Ибрахим. Поэт, историк и путешественник. Является автором ряда книг по истории мусульманских стран и известных правителей. В частности, его перу принадлежат трактаты о биографии Тимура и Бейбарса. Также он написал ряд книг в области языковых наук.

${ }^{70}$ Автор - Ибн 'Арабшах. Книга посвящена биографии Тимура.

${ }^{71}$ Мухаммад ал-Булгари (?-?). Об этой личности почти ничего неизвестно. Он упоминается в некоторых биографических справочниках ханафитских учёных.

72 Наджм ад-дин Мухтар аз-Захиди ал-Газмини (ум. 1260 г.), полное имя - Мухатр ибн Махмуд ибн Мухаммад Абу Раджа, известный ханафитский факих. Наджм ад-Дин Абу ар-Раджа’ Мухтар ибн Махмуд ал-Газмини (?-658 г. [1259 г.]): Надж ад-дин Абу арРаджа’ Мухтар ибн Махмуд ибн Мухаммад аз-Захиди ал-Газмини. Ханафитский правовед и матуридитский мутакаллим. Написал ряд книг по каламу, ханафитскому праву и усул ал-фикху. 
фитской книге по фикху «Мухтасар ал-кудури» ${ }^{73}$. Продолжая анализ данного вопроса, Ш. Марджани ссылается на трактаты имама А'зама бин 'Абд арРахмана ат-Тенеки ${ }^{74}$, однако не указывает их название. Он лишь указывает дату создания: «...в своей книге, написанной в 1146 г. (1733 г.)...». Также он ссылается на трактат Абу ан-Насра ал-Курсави, хотя и не называет его. Судя по содержанию цитат речь идет об «Иршад ли ал-“ибад» («Наставление рабам (Аллаха - A.P.)»). Далее он ссылается на устные высказывания татарских имамов, среди которых: мулла Ибрахим, мулла 'Абд ар-Рахим, ахунд Тадж ад-Дин, мулла 'Али Ниязакул ат-Туркмани, муфтий 'Абд ас-Салам, шейх Ни“матулла ишан из Стерлибаша, мулла Фахрутдин ал-Бахтарий, мулла Исхак-и Фахрутдин, мулла Хабибулла ибн Рахманкули [14, с. 68-72].

Для анализа биографий богословов, выявления исторического периода их проживания Ш. Марджани обращается к книге «Джавахир ал-муди'а», полное название которого - «ал-Джавахир ал-муди'а фи табакат ал-ханафийа» [4] («Сверкающие жемчужины о биографиях ханафитов»). Данная книга представляет собой сборник биографий ханафитских богословов. Ее автором является Мухи ад-Дин Абу Мухаммад 'Абд ал-Кадир ибн Мухаммад ибн Мухаммад ибн Наср Аллах ибн Салим ибн Абу ал-Вафа ал-Кураши ал-Ханафи 696775 гг. (1296-1373). Также он упоминает известную энциклопедию ученых и их трудов «Кашф аз-зунун», принадлежащую перу Хаджи Халифы.

Среди булгарских богословов Ш. Марджани перечисляет Йа'куба ибн Ну“мана ал-Булгари, Абу ал-“Ала Хамида ибн Идриса ал-Булгари, Сулеймана ибн Дауда ас-Саксини, Ахмада ал-Бургари, Ахмада ибн 'Абдуллу алКирмани.

Этими людьми были написаны такие труды как книга, посвященная истории Булгара, «Зухрат ар-рийад...», «Усул фахр ал-ислам», комментарии к «Кашф ал-кабир» и «Усул ал-хусами», «Фаваид ал-давахир», «Кунья», «Мухтасар ал-викайа», «Фаваид ал-Бургари».

Среди богословов периода Золотой Орды Ш. Марджани упомянул Бурхан ад-Дина Ибрахима ибн Хидра ал-Булгари ал-Ханафи, Абу Мухаммада Садра ибн 'Ала ад-Дина ал-Булгари, Хасана ибн 'Умара ал-Булгари, Бурхан ад-Дина Ибрахима ибн Йусуфа ал-Булгари, Наджм ад-Дина Абу ар-Раджа' Мухтара ибн Махмуда ибн Мухаммада ал-Казани ал-Ханафи, Ахмада ибн Махмуда ал-Джунди, Кутб ад-Дина Мухаммада ибн Мухаммада ар-Рази ашШафи“ий, Минхадж ад-Дина Ибрахима ибн Сулеймана ас-Сараи, Ахмада ибн Шамс ал-А'имма ас-Сараи, Са'д ад-Дина Мас'уда ибн 'Умара ал-Хорасани ан-Насаи аш-Шафи“и ат-Тафтазани, Камал ад-Дина ал-Худжанди, Хафиз адДина Мухаммада ибн Мухаммада ибн Шихаба ибн Йусуфа ал-Хаваризми алКрадари, 'Исама ибн ал-Малика ал-Маргинани, Шихаб ад-Дина Ахмада ибн Мухаммада ибн 'Абдуллу ал-Кураши ад-Димашки, Мухаммада ал-Булгари.

Ими были написаны такие труды как «Усул ал-Хусами», «Шарх адаб ассахаиф», комментарий «Для книги “Фусул ан-насафи”», «ал-Кунйа», комментарий к «Мухтасар ал-Кудури», «Рисала-и насырийа», «Мисбах», «Китаб алмухакамат», «ар-Рисала ал-ма“мула», «аш-Шамсиййа», «ал-Хави ас-сагир»,

${ }^{73}$ Известная книга по ханафитскому праву. Автор - Ахмад ибн Мухаммад ибн Ахмад ибн Джа'фар ибн Хамдан ал-Кудури, род. 362 г. (973 г.).

${ }^{74}$ Информация об этом ученом не обнаружена. Из слов Марджани следует, что имам ат-Тенеки жил в XVIII в. 
«Мафатих ал-акфал», комментарий к «“Ака’ид ан-Насафи», «Фатава Базазийа», «Хазинат ал-'улама ва зинат ал-фукаха», субкомментарии к таким книгам как «Талвих», «Шарх 'акаид ан-Насафийа».

Выявленные богословы и их труды представляют собой огромный пласт неизученного булгаро-татарского письменного наследия. Перед ученым сообществом историков и теологов на данный момент стоит задача обнаружения упомянутых рукописных списков, опубликованных трудов. Уточнение и более подробное описание их биографий является важной задачей, без которой невозможно введение в научный оборот и возрождение наследия российских богословов.

\section{СПИСОК ЛИТЕРАТУРЫ}

1. Адыгамов P.К. Источниковая база первого тома «Мустафад ал-ахбар фи ахвали Казан ва Булгар» Ш. Марджани // Золотоордынское обозрение. 2019. Т. 7, № 4. C. 674-686. DOI: 10.22378/2313-6197.2019-7-4.674-686.

2. ал-Джами А. Нафахат ал-унс мин хадарат ал-кудс. Бейрут: Дар ал-кутуб ал'илмийа, 2003. Т. 2. С. 845 с.

3. Ахмадуллин C.3. “Талфик ал-ахбар...” (“Свод сведений...”) Мурада Рамзи как источник по истории башкир. Диссертация на соискание ученой степени кандидата исторических наук. М., 2018. 68 с.

4. Госманов М.А. Шиһабетдин Мәржани һәм тарихи чыганакларны өйрәнү // Мәржани: тарих һәм хәзерге заман. Мәкаләләр жыентыгы. Казан: Мастер Лайн, 1998. 17 б.

5. Марджани Ш. Мустафад ал-ахбар фи ахвали Казан ва Булгар. Казань, 1900. T. $1.264 \mathrm{c}$.

6. Миргалеев И.М. Ш. Мәржанинең Алтын Урда тарихына карашы // Шихабетдин Мәржани: Мирасы һәм хазерге заман / Шигабутдин Марджани: наследие и современность. Казан: «Алма-Лит», 2008. Б. 102-109.

7. Миргалеев И.М. Шиһабетдин Мәржани мирасыннан // Эхо веков=Гасырлар авазы. 2008. № 1. С. 179-195.

8. Миргалеев И.М., Абызова Р.Р. Шихабетдин Марджани о Золотой Орде // Золотоордынское обозрение. 2018. Т. 6, № 1. С. 181-198. DOI: 10.22378/23136197.2018-6-1.181-198

9. Рамзи М. Талфик ал-ахбар фи вакаи“ Казан ва Булгар ва мулук ат-татар. Бейрут: Дар ал-кутуб ал-“илмийа, 2002. 736 с.

10. Челяби М. Кашф аз-зунун 'ан асами ал-кутуб ва ал-фунун. Бейрут, 1971. Т. 1. $488 \mathrm{c}$.

11. Челяби М. Кашф аз-зунун 'ан асами ал-кутуб ва ал-фунун. Стамбул: Маариф, 1941. T. $1.940 \mathrm{c}$.

12. Шарафутдинов Д. Саксин - древний булгарский город. 05.11.2015. Режим доступа: https://posredi.ru/saksin-drevnij-bulgarskij-gorod.html (дата обращения 15.03.2020).

13. Юзмухаметов Р.T. Структура текста и языковые особенности «Китабе Мустафад аль-ахбар фи ахвали Казан ва Булгар» («Книга использованных сведений по истории Казани и Булгара») Шигабутдина Марджани. Диссертация на соискание ученой степени кандидата филологических наук. Казань, 2002. 204 с.

Сведения об авторе: Рамиль Камилович Адыгамов - кандидат исторических наук, старший научный сотрудник Отдела истории религий и общественной мысли 
Института истории им. Ш. Марджани АН РТ (420111, ул. Батурина, 7А, Казань, Российская Федерация); ORCID: 0000-0002-0448-0107. E-mail: abu_muhammad@mail.ru

Поступила 04.03.2021 Принята к публикаџии 12.05.2021

Опубликована 29.06.2021

\section{REFERENCES}

1. Adygamov R.K. Istochnikovaya baza pervogo toma "Mustafad al-akhbar fi akhvali Kazan va Bulgar" Sh. Mardzhani [Marjani's sources for the first volume of his "Mustafad al'-akhbar fi Ahwali Qazan wa Bulgar"]. Zolotoordynskoe obozrenie = Golden Horde Review. 2019, vol. 7, no. 4, pp. 674-686. DOI: 10.22378/2313-6197.2019-74.674-686 (In Russian)

2. al-Jami A. Nafahat al-uns min hadarat al-kuds [The Separation of Intimate Conversation from the Presence of Holiness]. Beirut: Dar al-kutub al-'ilmija, 2003, vol. 2. 845 p. (In Arabic)

3. Ahmadullin S.Z. "Talfik al-ahbar..." ("Svod svedenij...") Murada Ramzi kak istochnik po istorii bashkir. Dissertaciya na soiskanie uchenoj stepeni kandidata istoricheskih nauk [The "Talfiq al-Akhbar..." ("Summary of Information...”) of Murad Ramzi as a Source for the History of Bashkirs. PhD Thesis]. Moscow, 2018. 68 p. (In Russian)

4. Gosmanov M.A. Shihabetdin Marjani ham tarihi chyganaklarny ojranu jyentygy [Shihabutdin Marjani and the study of historical sources]. Marjani: tarih ham hazerge zaman. Makalalar [Marjani: History and Modernity]. Kazan: Master Line, 1998. 17 p. (In Tatar)

5. Marjani Sh. Mustafad al-ahbar fi ahvali Kazan va Bulgar [The Book of Useful Information on the History of Kazan and Bolgar]. Kazan, 1900, vol. 1. 264 p. (In Tatar)

6. Mirgaleev I.M. Sh. Mərjaninen Altyn Urda tarihyna karashy [Views of Sh. Marjani on the History of the Golden Horde]. Shihabutdin Mardzhani: nasledie $i$ sovremennost' [Shigabutdin Marjani: Heritage and Modernity]. Kazan: Alma-Lit, 2008, pp. 102-109. (In Tatar)

7. Mirgaleev I.M. Shihabetdin Marjani mirasynnan [From the heritage of Sh. Marjani]. Ekho vekov - Gasyrlar avazy [Echo of Centuries]. 2008, no. 1, pp. 179-195. (In Tatar)

8. Mirgaleev I.M., Abyzova R.R. Shikhabetdin Mardzhani o Zolotoy Orde [Shihabutdin Marjani on the Golden Horde]. Zolotoordynskoe obozrenie=Golden Horde Review. 2018, vol. 6, no. 1, pp. 181-198. DOI: 10.22378/2313-6197.2018-6-1.181-198 (In Russian)

9. Ramzi M. Talfik al-ahbar fi vakai“ Kazan va Bulgar va muluk at-tatar [Summary of the Events of Kazan, Bulgar, and Tatar Rulers]. Beirut: Dar al-kutub al-'ilmija, 2002. 736 p. (In Turkish)

10 Chelyabi M. Kashf az-zunun 'an asami al-kutub va al-funun [Removing the Doubts about the Names of Books and Sciences]. Beirut, 1971, vol. 1. 488 p. (In Turkish)

11. Chelyabi M. Kashf az-zunun 'an asami al-kutub va al-funun [Removing the Doubts about the Names of Books and Sciences]. Stambul: Maarif, 1941, vol. 1. 940 p. (In Turkish)

12. Sharafutdinov D. Saksin - drevniy bulgarskiy gorod [Saksin: Ancient Bulgar City]. 05.11.2015. Available at: https://posredi.ru/saksin-drevnij-bulgarskij-gorod.html (accessed 15.03.2020).

13. Yuzmukhametov R.T. Struktura teksta i yazykovye osobennosti "Kitabe Mustafad al'-ahbar fi ahvali Kazan va Bulgar" ("Kniga ispol'zovannyh svedenij po istorii Kazani $i$ Bulgara”) Shigabutdina Mardzhani. Dissertaciya na soiskanie uchenoj stepeni kandidata 
filologicheskih nauk [The Text Structure and Language Features of the "Kitabe Mustafad al-akhbar fi ahvali Kazan va Bulgar" ("Book of Useful Information on the History of Kazan and Bulgar”) of Shigabutdin Marjani. PhD Thesis]. Kazan, 2002. 204 p. (In Russian)

About the author: Ramil K. Adygamov - Cand. Sci. (History), Senior Researcher of the Department of History of Religions and Public Thought of the Marjani Institute of History of Tatarstan Academy of Sciences (7A, Baturin Str., Kazan 420111, Russian Federation); ORCID: 0000-0002-0448-0107. E-mail: abu_muhammad@mail.ru

Received March 4, 2021 Accepted for publication May 12, 2021 Published June 29, 2021 


\title{
ПРОМЕДЛЕНИЕ ИВАНА IV ПРИ ВЗЯТИИ КАЗАНИ: ПРОЯВЛЕНИЕ ИНОСКАЗАТЕЛЬНОСТИ СРЕДНЕВЕКОВЫХ ТЕКСТОВ И РЕАЛЬНОЙ ПОВЕДЕНЧЕСКОЙ ПРАКТИКИ
}

\author{
А.В. Аксанов \\ Институт истории им. Ш. Марджани АН РТ \\ Казань, Российская Федерация \\ aksanov571@gmail.com
}

Цель исследования: изучить семантику известий о промедлении Ивана IV при штурме Казани.

Материаль исследования: летописи и сказания, разрядные книги, дипломатические документы, актовый материал, сочинения иностранцев о Московии, материалы переписки Ивана IV с А.М. Курбским и т.д.

Результаты и научная новизна исследования: изучение официальных известий о поведении Ивана IV во время штурма Казани 2 октября 1552 г. в контексте подобных сообщений о Стоянии на Угре 1480 г. и Куликовской битве 1380 г. позволило выявить иносказательные элементы в описании действий царя. Вместе с тем историчность сообщений официальных источников об откладывании Иваном IV выхода к войскам подтверждается рассказом А.М. Курбского, который, при этом, по-другому объяснил мотивы действия царя. Воспоминания А.М. Курбского, указывающие на проявление паталогического страха в поступках Ивана IV, подтверждаются анализом поведения царя во время опричнины, когда более рельефно выразились его личностные качества. Развивая мысль о психологических качествах царя, делается вывод о том, что излишняя категоричность Ивана IV в конфессиональной политике стала серьезным препятствием на пути инкорпорации народов Поволжья в Московское государство.

Ключевые слова: Иван IV Грозный, взятие Казани 1552 г., опричнина, Поволжье, Казанское ханство, Московское государство

Для цитирования: Аксанов А.В Промедление Ивана IV при взятии Казани: проявление иносказательности средневековых текстов и реальной поведенческой практики // Золотоордынское обозрение. 2021. Т. 9, № 2. С. 351-358. DOI: 10.22378/23136197.2021-9-2.351-358 


\title{
IVAN IV'S POSTPONEMENT OF THE ASSAULT ON KAZAN: A MANIFESTATION OF THE ALLEGORICAL NATURE OF MEDIEVAL TEXTS AND REAL BEHAVIORAL PRACTICE
}

\author{
A.V. Aksanov \\ Marjani Institute of History of Tatarstan Academy of Sciences \\ Kazan, Russian Federation \\ aksanov571@gmail.com
}

\begin{abstract}
Research objectives: To study the semantics of textual reports about Ivan IV's postponing of the assault on Kazan.

Research materials: Chronicles and tales, Razriad books, diplomatic documents, act materials, foreign works about Muscovy, materials from the correspondence of Ivan IV with A.M. Kurbsky, etc.

Results and novelty of the research: The author identified allegorical elements in the description of Ivan IV's behavior during the assault on Kazan on October 2, 1552 by comparing this description with similar reports about the Stand on the Ugra in 1480 and the Battle of Kulikovo in 1380. Importantly, the reliability of the reports of official sources about Ivan IV's postponement of his riding out to join the troops is confirmed by the account of A.M. Kurbsky, who explained the motives of the tsar's action in a different way. The memories of A.M. Kurbsky, indicating the manifestation of pathological fear behind the actions of Ivan IV, are confirmed by the analysis of the tsar's behavior during the Oprichnina, when his personal qualities were expressed more vividly in source material. It is concluded that Ivan IV's excessive categorism in his confessional policy became a serious obstacle to the incorporation of the peoples of the Volga region into the Muscovite State. Consequently, Ivan IV played a significant, but mostly negative, role in the assault on Kazan in 1552 as well as during the process of incorporating the peoples of the Volga region into Russia.
\end{abstract}

Keywords: Ivan IV Terrible, 1552 conquest of Kazan, Oprichnina, Volga region, Kazan khanate, Muscovite State

For citation: Aksanov A.V. Ivan IV's Postponement of the Assault on Kazan: A Manifestation of the Allegorical Nature of Medieval Texts and Real Behavioral Practice. Zolotoordynskoe obozrenie $=$ Golden Horde Review. 2021, vol. 9, no. 2, pp. 351-358. DOI: 10.22378/2313-6197.2021-9-2.351-358

Из всех событий, связанных с правлением Ивана IV Грозного (15331584), наиболее значительный отпечаток в исторической памяти оставило взятие Казани 1552 г. Судьбоносность этого события для истории России очевидна, однако дискуссионным остается вопрос о роли самого царя в организации штурма Казани. Причем почву для такой дискуссии подготовили современники и очевидцы событий, по-разному оценивавшие поведение Ивана IV.

Один из самых ранних рассказов о взятии Казани сохранился в «Летописце начала царства». Это сообщение датируется 1553 г., многие официальные книжники продолжали копировать его без существенных изменений и в 1560-е гг. Согласно данному известию, 2 октября 1552 г. во время штурма Казани Иван IV молился в церкви «с великим вопом, плачем и стенанием сердечным». А когда царю сообщили, что пришло время выдвигаться и его ждут «многие полки», он ответил, что необходимо дождаться окончания пе- 
ния, чтобы получить «совершенную милость от Христа». И когда во второй раз царя попросили выехать к войскам, чтобы поддержать их своим присутствием, он «вздохнув из глубины сердца своего и слезы многие проливая рече: "Не оставь меня Господи Боже мои, и не отступи от меня, вонми в помощь мою”». При этом Иван IV не торопился покинуть службу. Перед выходом к войскам он помолился перед образом чудотворца Сергия, причастился святой водой и хлебом, и после окончания литургии, получив благословение от протопопа Андрея, вышел из церкви. Затем он вновь обратился к богомольцам с речью и только после этого отправился к своим полкам [8, с. 217; 9, с. 528-529; 10, с. 106-107, 201-202].

Промедление Иван IV в момент кульминации штурма нередко воспринималось историками как проявление малодушия, неблагоприятно сказавшееся на боевом духе русского войска $[13$, с. $47 ; 2$, с. 140]. Впрочем, необходимо учитывать, что представленное летописное сообение написано по определенным литературным канонам и вместе с буквальным смыслом содержит иносказательные элементы. Схожим образом описаны действия Дмитрия Донского перед походом против Мамая и Ивана III накануне стояния на Угре. Более подробно суть промедления накануне сражения раскрывается в «Сказании о Мамаевом побоище».

Когда Дмитрий Донской стал торопиться для выступления против Мамая, Сергий Радонежский объяснил ему, что «промедление двойной для тебя помощью обернется. Ибо не сейчас еще, господин мой, смертный венец носить тебе, но через несколько лет, а для многих других теперь уж венцы плетутся» $[12$, с. 150]. Далее, описывая Куликовскую битву, автор «Сказания» вновь обращает внимание читателя на пользу промедления. Опытный воевода Дмитрий Боброк-Волонский остановил торопившегося на помощь князя Андрея Владимировича следующими словами: «Беда, княже, велика, но еще не пришел наш час: начинающий раньше времени вред себе принесет; ибо колосья пшеничные подавляются, а сорняки растут и буйствуют над благорожденными. Так что немного потерпим до времени удобного и в тот час воздадим по заслугам противникам нашим. Ныне только повели каждому воину Богу молиться прилежно и призывать святых на помощь, и с этих пор снизойдет благодать Божья и помощь христианам» [12, с. 180].

Следовательно, официальные летописцы, описывая промедление Ивана IV при штурме Казани, указывали на проявление государевой мудрости, заключавшейся в том, что царь последовал совету Сергия Радонежского и действовал по примеру своих дедов - дождался часа снисхождения Божьей помощи и обрел победу. В то же время, акцентируя внимание читателя на том, что царь задержался из-за молитвы, летописцы попытались отвести от него подозрения в трусости. Тогда как А.М. Курбский, участвовавший во взятии Казани, писал об этом. По его словам, многие из христиан, войдя в город, предались грабежу, а мусульмане, воспользовавшись ситуацией, контратаковали и обратили их в бегство. Видя отступление русских войск, царь изменился лицом, «и сердце у него сокрушилось». А.М. Курбский вспоминал, что спасти положение удалось мудрым воеводам, которые «распорядились воздвигнуть большую христианскую хоругвь у городских ворот, называемых Царскими, и самого царя, взяв за узду коня его, - волей или неволей - у хоругви поставили» [7, с. 347]. 
Таким образом, как бы то ни было, официальные летописи говорят о том, что в момент решающего штурма Иван IV задержал подкрепление, при этом, согласно А.М. Курбскому, царь впал в страх и нерешительность. Конечно, у любого человека в подобных условиях могут возникнуть эти чувства, однако царь был так сильно испуган, что воеводам пришлось взять его коня за узду. Причем необходимо учитывать то, что Ивану IV не предстояло отправиться в пучину сражения: ему необходимо было лишь появиться в войсках и отправить их на штурм города. Поэтому такое поведение нельзя охарактеризовать даже как проявление малодушия. Оно более похоже на серьезное психическое расстройство, рельефно проявившееся в экстраординарной ситуации.

Можно ли доверять А.М. Курбскому? С одной стороны, известно, что он был противником Ивана IV и мог предвзято описать случившееся, но с другой стороны, многие его сведения подтверждаются независимыми источниками, а в данном случае его сообщение вполне коррелируется с официальными известиями. К тому же, биография Ивана IV изобилует и другими примерами девиантного поведения, обращение к которым поможет понять, насколько описание А.М. Курбского соответствует поведенческой практике царя.

Наиболее благоприятным периодом для формирования паталогических страхов и других отклонений является детский этап развития личности. Ученые историки и психологи уже не раз обращали внимание на то, что у Ивана IV было очень тяжелое детство: его постигло сиротство, не раз он становился очевидцем кровавых расправ, чинимых боярами в борьбе за власть.

Более отчетливо душевные недуги царя, проявились уже после завоевания Казанского ханства. К примеру, самым труднообъяснимым явлением российской истории является опричнина, которая началась по инициативе самого Ивана IV и отражает его личные убеждения. Немало историков сломало копья, пытаясь объяснить природу опричнины. Чаще всего в ней искали рациональное политическое начало. Одни ученые писали, что опричнина была направлена против самовластия бояр [14, с. 169-170; 5, с. 302], другие считали ее инструментом борьбы с пережитками удельной старины [4], третьи - способом централизации государства [6] или утверждения самодержавия [3]. Так или иначе, все эти социально-политические теории до конца не объясняют феномен опричнины. Очевидно, что опричнина была связана не столько с социально-политической ситуацией, сколько с религиознонравственными переживаниями русского общества в целом и самого царя в частности. А.Л. Юрганов справедливо связывал начало опричнины со второй волной эсхатологических ожиданий, обострившихся накануне 7077 гг. от сотворения мира по православному календарю, что приходилось на 1569 г. от рождества Христова [16]. В целом ожидания Конца Света должны были сопровождаться усилением религиозности, выражавшейся в более тщательном соблюдении божественных установлений и росте нравственности, однако были и случаи девиантного поведения. Один из таких примеров - деятельность Ивана IV, который в силу своих психических отклонений весьма своеобразно воспринимал происходящее.

Царь считал себя помазанником Божьим, наместником Бога на земле и ответственным за грехи вверенной ему паствы. В условиях приблизившегося Судного дня он решил радикальным способом избавить общество от наказаний за грехи. Все грешники должны были очиститься с помощью жестоких 
казней и пыток, подобных тем, которые предстояли им в аду. Причем наиболее серьезным грехом Иван IV считал измену государю. По его мнению, изменники должны были придаваться самым сильным наказаниям [11, с. 19, 85, $242-243,249,256]$. С одной стороны, кажется, что этот постулат давал широкий простор для борьбы с любыми проявлениями оппозиции и был лишь оправданием насильственных действий против политических врагов. Но чаще всего обвинения в заговоре против царя были обусловлены не реальной угрозой, а ничем не обоснованными паранойяльными страхами самого Ивана IV. На то, что в основе действий царя лежали не прагматические расчеты, а психические отклонения, указывают и жестокие казни людей, не имеющих никакого отношения к политике. К примеру, тысячи рядовых горожан, в том числе женщин и детей, погибло во время новгородского погрома. В течение всей опричнины множество людей казнили по обвинению в колдовстве. Были случаи, когда вместе с опальными «изменниками» жестоким казням подвергались их жены и малолетние дети.

Политика опричнины вместе с Ливонской войной привела к разорению страны, в результате чего началось массовое бегство крестьян в казаки. Помимо острого социально-экономического кризиса, наследством Ивана IV стала династическая проблема ${ }^{1}$. В совокупности все это породило Смуту, которую с трудом пережила российская государственность. Таким образом, роль личности царя в завоевании Казани, как и в других последующих событиях истории России, была весьма значительной, но во многом деструктивной. Зачастую серьезные психологические недуги не позволяли Ивану IV адекватно оценивать происходящее и принимать взвешенные решение, результатом чего стали многочисленные военно-политические и социальноэкономические катастрофы, поставившие русское общество и соседние народы в крайне критическое положение.

В течение своего правления Ивану IV так и не удалось полностью подчинить население Казанского края. Около сорока лет после взятия Казани народы Поволжья и Приуралья продолжали борьбу против власти «белого царя». Столь упорное сопротивление во многом было вызвано мерами по интенсивной христианизации, принятыми Иваном IV. В 1555 г. царь учредил Казанскую епархию и «наказал» казанскому архиепископу крестить инородцев, дабы укрепить русскую власть. Побуждать к крещению должны были налоговые льготы, подарки и ходатайство архиепископа за осужденных мусульман и язычников. В крупных населенных пунктах на месте разрушенных мечетей были построены православные храмы, ставшие центрами активной миссионерской деятельности. В 1550-1570-е гг. Иван IV пожаловал монастырям обширные земли в стратегически важных районах «Казанского царства». Но наиболее болезненным решением для мусульман был запрет на строительство мечетей в центральных поселениях. Эта мера не позволяла выпол-

${ }^{1}$ После Ивана IV не осталось наследников, способных править и продолжать царский род. Династия Рюриковичей, много веков правившая русскими землями, прервалась. По сообщениям иностранцев и более поздних русских источников, Иван IV собственноручно убил своего сына Ивана, который был главным наследником престола. Некоторые историки считают факт убийства своего сына домыслами иностранцев, но это известие подтверждается несколькими не связанными друг с другом сообщениями русских авторов XVII в. [15]. 
нять одно из обязательных предписаний ислама - коллективную пятничную молитву, которая могла быть организовано только в крупных населенных пунктах, где располагался суд, рынок, и были представители власти. Поэтому только после смерти царя, когда местные воеводы начали закрывать глаза на строительство мечетей ${ }^{2}$ и перестали активно помогать миссионерской деятельности, освободительное движение пошло на спад.

Таким образом, в деле присоединения народов Поволжья, как и при взятии Казани 1552 г., личностные качества Ивана IV сыграли негативную роль. На этот раз, его бескомпромиссность в конфессиональной политике привела к затяжному конфликту, который унес десятки тысяч жизней. Поэтому трудно согласится с мнением историков, которые считают завоевание Казани и присоединение Поволжья заслугой Ивана IV.

\section{СПИСОК ЛИТЕРАТУРЫ}

1. Акты, собранные в библиотеках и архивах Российской империи Археографическою экспедициею императорской Академии наук, Т. 1: 1294-1598. СПб.: В типографии Экспедиции заготовления Государственных бумаг, 1836. 506 с.

2. Алишев С.X. Казань и Москва: Межгосударственные отношения XV-XVI вв. Казань: Татарское книжное издательство, 1995. 160 с.

3. Альшии Д.Н. Начало самодержавия в России: Государство Ивана Грозного. Л.: Наука, 1988. 244 с.

4. Зимин А.А. Опричнина Ивана Грозного. М.: Мысль, 1964. 535 с.

5. Ключевский В.О. Русская история. Полный курс лекций. М.: Олма-ПРЕСС Образование, 2005. 974 с.

6. Кобрин В.Б. Иван Грозный. М.: Московский рабочий, 1989. 175 с.

7. Курбский А.М. История о великом князе Московском // Библиотека литературы Древней Руси. СПб.: Наука, 2001. Т. 11. С. 310-479.

8. Полное собрание русских летописей, Т. 13. Ч. 1: Патриаршая или Никоновская летопись. СПб.: Типография И.Н. Скороходова, 1904. 302 с.

9. Полное собрание русских летописей, Т. 20: Львовская летопись. М.: Языки славянской культуры, 2005 . iv +704 c.

10. Полное собрание русских летописей, Т. 29: Летописец начала царства царя и великого князя Ивана Васильевича. Александро-Невская летопись. Лебедевская летопись. М.: Наука, 1965. 390 с. $552 \mathrm{c}$.

11. Послания Ивана Грозного. М.; Л.: Издательство Академии наук СССР, 1951.

12. Сказание о Мамаевом побоище // Библиотека литературы Древней Руси. СПб.: Наука, 1999. Т. 6. С. 138-189.

13. Скрынников Р.Г. Иван Грозный. М.: Наука, 1983. 250 с.

14. Соловьёв С.М. История России с древнейших времён. СПб.: «Общественная польза», 1896. Кн. 2. Т. V-Х. 1726 стб.

15. Шокарев С. Убивал ли Иван Грозный своего сына? // Историк. 2017. № 1. C. $42-49$.

${ }^{2}$ В 1593 г. казанский митрополит Гермоген жаловался царю Федору Ивановичу, что казанские воеводы не обращают внимания на строительство мечетей, запрещенное Иваном IV. По словам митрополита, «от казанского взятья в сорок лет, не бывали в Татарской слободе мечети, а ныне де учали мечети ставити близко посаду» [1, с. 437]. 
16. Юрганов А.Л. Опричнина и страшный суд // Отечественная история. 1997. № 3. C. 52-75.

Сведения об авторе: Анвар Васильевич Аксанов - кандидат исторических наук, старший научный сотрудник Центра исследований Золотой Орды и татарских ханств им. М.А. Усманова Института истории им. Ш. Марджани АН РТ (420111, ул. Батурина, 7А, Казань, Российская Федерация); ORCID: 0000-0001-8970-5880. E-mail: aksanov571@gmail.com

Поступила 08.03.2021 Принята к публикации 27.05.2021

Опубликована 29.06.2021

\section{REFERENCES}

1. Akty, sobrannye $v$ bibliotekakh $i$ arkhivakh Rossiyskoy imperii Arkheograficheskoyu ekspeditsieyu imperatorskoy Akademii nauk, T. 1: 1294-1598 [Acts Collected in the Libraries and Archives of the Russian Empire by the Archaeographic Expedition of the Imperial Academy of Sciences, Vol. 1: 1294-1598]. St. Petersburg, 1836. 506 p. (In Russian)

2. Alishev S.Kh. Kazan' i Moskva: Mezhgosudarstvennye otnosheniya XV-XVI vv. [Kazan and Moscow: The Interstate Relations of the fifteenth and sixteenth century]. Kazan: Tatar book publishing house, 1995. 160 p. (In Russian)

3. Al'shits D.N. Nachalo samoderzhaviya v Rossii: Gosudarstvo Ivana Groznogo [The Beginning of Autocracy in Russia: The State of Ivan the Terrible]. Leningrad: Nauka, 1988. 244 p. (In Russian)

4. Zimin A.A. Oprichnina Ivana Groznogo [Ivan the Terrible's Oprichnina]. Moscow: Thought, 1964. 535 p. (In Russian)

5. Klyuchevskiy V.O. Russkaya istoriya. Polnyy kurs lektsiy [Russian History. Full Course of Lectures]. Moscow: Olma-Press Obrazovanie, 2005. 974 p. (In Russian)

6. Kobrin V.B. Ivan Groznyy [Ivan the Terrible]. Moscow: Moscow worker, 1989. 175 p. (In Russian)

7. Kurbskiy A.M. Istoriya o velikom knyaze Moskovskom [History about the Grand Prince of Moscow]. Biblioteka literatury Drevney Rusi [Library of Literature of Ancient Rus']. St. Petersburg: Nauka, 2001, vol. 11 pp. 310-479. (In Russian)

8. Polnoe sobranie russkikh letopisey, T. 13. Ch. 1: Patriarshaya ili Nikonovskaya letopis' [Complete Collection of Russian Chronicles, Vol. 13. Part 1: Patriarchal or Nikon Chronicle]. St. Petersburg: Skorokhodov's printing house, 1904. 302 p. (In Russian)

9. Polnoe sobranie russkikh letopisey, T. 20 : L'vovskaya letopis' [Complete Collection of Russian Chronicles, Vol. 20: Lvov Chronicle]. Moscow: Languages of Slavic culture, 2005. iv + 704 p. (In Russian)

10. Polnoe sobranie russkikh letopisey, T. 29: Letopisets nachala tsarstva tsarya $i$ velikogo knyazya Ivana Vasil'evicha. Aleksandro-Nevskaya letopis'. Lebedevskaya letopis' [Complete Collection of Russian Chronicles, Vol. 29: Chronicler of the Beginning of the Reign of Tsar and Grand Duke Ivan Vasilyevich. Aleksandro-Nevskaya Chronicle. Lebedevskaya Chronicle]. Moscow: Nauka, 1965. 390 p. (In Russian)

11. Poslaniya Ivana Groznogo [Ivan the Terrible's Messages]. Moscow; Leningrad: Publishing house of the USSR Academy of Sciences, 1951. 552 p. (In Russian) 
12. Skazanie o Mamaevom poboishche [The Tale of Mamay's Defeat]. Biblioteka literatury Drevney Rusi [The Library of Old Russian Literature]. St. Petersburg: Nauka, 1999, vol. 6, pp. 138-189. (In Russian)

13. Skrynnikov R.G. Ivan Groznyy [Ivan the Terrible]. Moscow: Nauka, 1983. 250 p. (In Russian)

14. Solov'ev S.M. Istoriya Rossii s drevneyshikh vremen [History of Russia since Most Ancient Times]. St. Petersburg: Public benefit, 1896, book 2, vol. 5-10. 1726 p. (In Russian)

15. Shokarev S. Ubival li Ivan Groznyy svoego syna? [Did Ivan the Terrible kill his son?]. Istorik [Historian] 2017, no. 1. pp. 42-49. (In Russian)

16. Yurganov A.L. Oprichnina i strashnyy sud [Oprichnina and terrible court]. Otechestvennaya istoriya [Domestic History]. 1997, no. 3. pp. 52-75. (In Russian)

About the author: Anvar V. Aksanov - Cand. Sci. (History), Senior Research Fellow, Usmanov Center for Research on the Golden Horde and Tatar Khanates, Marjani Institute of History of Tatarstan Academy of Sciences (7A, Baturin Str., Kazan 420111, Russian Federation); ORCID: 0000-0001-8970-5880. E-mail: aksanov571@gmail.com

Received March 8, 2021 Accepted for publication May 27, 2021

Published June 29, 2021 


\title{
КУЧУМОВО ГОРОДИЩЕ - СТОЛИЧНЫЙ ГОРОД В СИБИРИ ИЛИ ИСТОРИЧЕСКИЙ МИФ (АРХЕОЛОГИЧЕСКИЕ ФАКТЫ И ИСТОРИЧЕСКИЕ ПРЕДПОЛОЖЕНИЯ)
}

\author{
A.A. Aдамов \\ Тобольская комплексная научная станичи \\ Уральского отделения Российской академии наук \\ Тобольск, Российская Федерачия \\ adamowaa@yandex.ru
}

Цель исследования: в статье критически рассматриваются аргументы, ставящие под сомнение городской статус столицы Сибирского ханства - Кучумова городища (Искера). Анализируются имеющиеся данные по площади, количеству жителей, торговле и ремеслу столичного города.

Материаль и исследования: основными источниками являются материалы, полученные в ходе археологических исследований на городище на протяжении XX начала XXI вв. Используются также артефакты из сборов, произведенных на отмели p. Иртыша из разрушенного культурного слоя памятника, собирать которые начали еще в 80-х годах XIX в. Использованы также картографические материалы С.У. Ремезова, В. Филимонова, В.Н. Пигнатти.

Результаты и новизна исследования: проведённый анализ имеющихся данных показал, что площадь памятника на конец XV в. составляла не менее 2,6 га, а археологические исследования А.П. Зыкова и автора выявили сложную многоуровневую систему укреплений, которые были возведены для обороны столицы Сибирского ханства. Находки 2019 года позволяют предполагать наличие в столице каменных сооружений из большемерного кирпича. Обнаруженные на городище артефакты свидетельствуют о важной роли Искера как торгового центра, расположенного на наиболее удобном пути, связывающем Среднюю Азию, Китай, Восточную Европу и таежные районы Западной Сибири. Население города широко использовало серебряные и медные монеты в торговых операциях. Собранные на Искере данные свидетельствуют и о живших и трудившихся здесь ремесленниках - кузнецах, литейщиках, ювелирах, портных и кожевенниках. Мощный культурный слой Кучумова городища, насыщенный огромным числом находок, мог сформироваться только в том случае, если в городе постоянно проживало довольно многочисленное (по сибирским меркам) население, состоявшее из ханской семьи и ее обслуги, приближенной знати, мусульманского духовенства, воинов, купцов, ремесленников. Совокупность имеющихся данных позволяют считать город Искер политическим, торговым, ремесленным и религиозным центром сибирских татар.

Ключевые слова: Сибирь, средневековье, Сибирское ханство, город Сибир, Кучумово городище, Искер

Для цитирования: Адамов А.А. Кучумово городище - столичный город в Сибири или исторический миф (археологические факты и исторические предположения) // Золотоордынское обозрение. 2021. Т. 9, № 2. C. 359-373. DOI: 10.22378/23136197.2021-9-2.359-373 


\title{
THE KUCHUM SETTLEMENT: THE CAPITAL OF SIBERIA OR A HISTORICAL MYTH (ARCHAEOLOGICAL FACTS AND HISTORICAL ASSUMPTIONS)
}

\author{
A.A. Adamov \\ Tobolsk Complex Scientific Station \\ of the Ural Branch of the Russian Academy of Sciences \\ Tobolsk, Russian Federation \\ adamowaa@yandex.ru
}

\begin{abstract}
Research objectives: The article scrutinizes the arguments challenging the urban status of the Kuchum settlement (Isker), the capital of the Siberian Khanate. The author analyzes the available data on the vicinity, population, trading, and craft production of this capital.

Research materials: The main sources are materials obtained during archaeological research in the ancient settlement in the twentieth and twenty-first century, as well as artifacts collected on the shallows of the Irtysh River from the destroyed cultural layer of the monument since the 1880s. The cartographic materials of S.U. Remezov, V. Filimonov, and V.N. Pignatti were also used in the study.

Results and novelty of the research: An analysis of the available data showed that the area of the monument reached at least 2.6 hectares by the late fifteenth century. In addition, archaeological research by A.P. Zykov and the author revealed a complex multi-level fortification system aimed at defending the capital of the Siberian Khanate. The artifacts found in 2019 suggest the presence of oversize brick structures in the capital. Such artifacts prove the important role of Isker as the center of trade located on the most convenient route which connected Central Asia, China, Eastern Europe, and the taiga regions of Western Siberia. The population of the settlement widely used silver and copper coins in trading. The collected data show that blacksmiths, casters, jewelers, tailors, and tanners lived and worked in Isker. A huge cultural layer, rich in artifacts, of the Kuchum settlement could be formed only by a fairly large population by Siberian standards, consisting of the khan's family and its servants, close members of the nobility, Muslim clergy, warriors, merchants, and artisans. The total available data allows us to consider Isker as the political, commercial, craft, and religious center of the Siberian Tatars.
\end{abstract}

Keywords: Siberia, Middle Ages, Siberian Khanate, town of Sibir, Kuchum settlement, Isker

For citation: Adamov A.A. The Kuchum Settlement: The Capital of Siberia or a Historical Myth (Archaeological Facts and Historical Assumptions). Zolotoordynskoe obozrenie=Golden Horde Review. 2021, vol. 9, no. 2, pp. 359-373. DOI: 10.22378/23136197.2021-9-2.359-373

Вялотекущая дискуссия, начатая в свое время Л.Р. Кызласовым [18], о наличии в Западной Сибири городов и их атрибуции [29; 3; 22] получила новый импульс с выходом объемной статьи Д.Н. Маслюженко и С.В. Татаурова. Исследователи считают, что условия расположения Искера и обнаруженные там артефакты не позволяют считать столицу Сибирского ханства крупным и хорошо укрепленным городом [19, с. 135]. Критический разбор этой версии уже был произведен Д.М. Исхаковым и 3.А. Тычинских с акцентом на политические аспекты, связанные со столичным статусом города [15]. Мы же попытаемся проанализировать высказанные Д.Н. Маслюженко и 
C.В. Татауровым положения, основываясь на имеющемся в нашем распоряжении комплексе находок и собственных наблюдений, полученных в результате археологических исследований на Искере.

Кучумово городище или Искер - столица Сибирского ханства располагалось на высокой надпойменной террасе р. Иртыш в 17 км выше по течению от устья Тобола. Из-за обрушения террасы (смывается водами Иртыша) от Искера осталась небольшая полоса площадки городища в форме вытянутого треугольника, шириной всего несколько метров в северо-восточной части и до 20 м - в юго-западной. Длина этого треугольника доходит до 88 м. Искер располагался в очень удобном для обороны месте. Со стороны Иртыша почти отвесный осыпающийся склон высотой более 50 м, с двух других такой же высоты крутой откос оврага, образованного р. Сибиркой. С напольной стороны площадку городища отделяли два смыкающихся оврага: один со стороны р. Сибирки, другой - со стороны р. Иртыш (уничтожен в результате осыпи террасы). Перепад высот от верхней точки террасы до наименьшей глубины оврага составляет 19 м.

Сборы на городище проводили: М.С. Знаменский в 80-е годы XIX в. [3, c. 10-18], многие тобольские краеведы в конце XIX - в начале XX вв. [3, c. 17-20], в том числе, В.Н. Пигнатти, проводивший раскопки в 1915 году [25]. В 1968 г. городище исследовала Б.Б. Овчинникова [24], в 1989 и 1993 гг. - А.П. Зыков [13], а в 2007 и 2008 гг. - автор. Нами же, начиная с 2006 г., ведутся ежегодные сборы на отмели у Искера, а в 2014 и 2015 гг. был исследован грунтовый могильник, расположенный у городища [1]. Огромный (более 4500 предметов) археологический материал (правда, опубликованы только дореволюционные сборы и материалы из раскопок А.П. Зыкова, хранящиеся в Тобольском музее-заповеднике, и альбом с рисунками находок М.С. Знаменского [14]), собранный на памятнике, как нам кажется, позволяет аргументированно ответить на вопрос - является ли Искер городом или все же кочевой ставкой.

Высказанные Д.Н. Маслюженко и С.Ф. Татауровым аргументы в пользу не городского статуса Искера, прежде всего, основаны на якобы небольшой площади памятника, вмещавшего, по их мнению, всего 150-300 человек [19, c. 139-141], и отсутствии доказательств о наличии серьезных укреплений [19, c. 140]. При анализе площади памятника исследователи опирались на данные Г.Ф. Миллера, который описывает площадку городища диаметром около 50 саженей [23, с. 135]. То есть площадь памятника в 1730-х годах, по его подсчетам, составляла где-то около 1 га. Но ведь еще в 1703 г. план столицы составил С.У Ремезов [5; 33, л. 79а], а в 1806 г. инструментальный план снял В. Филимонов [16, с. 208]. Промеры столицы на начало XX в. содержатся в статье В.Н. Пигнатти [25, с. 9]. Основываясь на этих данных, автор подсчитал площадь памятника с большой точностью на начало XVIII в., которая составляла около 1,8 га, а на начало XIX в. - около 0,9 га [2, с. 107]; и реконструировал возможную площадь столицы Сибирского ханства в конце XV и XVI вв. По нашим подсчетам минимальная площадь столичного города Сибир в конце XVI в. была около 2,2 га, а на момент основания столичного города в конце XV в. - около 2,6 га [2, с. 107]. При этом именно на этой площади и располагались все постройки города Сибирь. Никаких культурных отложений как с напольной стороны Искера, так и в непосредственной близо- 
сти от него не существует, и предположения и В.Н. Пигнатти [25, с. 17] и А.П. Зыкова, что Искер - это только цитадель расположенного к западу, северу и востоку от него позднесредневекового города Сибир [14, с. 419], не соответствуют зафиксированным реалиям.

Как показали исследования А.П. Зыкова [13], с напольной стороны и по склону оврага р. Сибирки Искер укреплялся сложной деревоземляной системой оборонительных сооружений. Наверное, не все выявленные укрепления можно отнести ко времени существования Сибирского ханства. Другие, возможно, выглядели не так величественно, как на реконструкции [13, рис. 4], но факт наличия достаточно сложной системы оборонительных укреплений, возведенных для столицы Сибирского ханства, отрицать просто невозможно. При этом и ранние Сибирские летописи, составленные еще по воспоминаниям казаков Ермака, называют Искер городом, а значит, он имел сложную оборонительную систему, по которой и судили о статусе поселения, отличая его от небольших острогов и укрепленных городков сибирских аборигенов $[27$, c. $47-56]$.

Итак, площадь столицы Сибирского ханства, укрепленной мощной оборонительной системой, не могла быть меньше 2,2-2,6 га. Если сравнивать Искер с золотоордынскими городами, имевшими порой размеры в несколько квадратных километров [30, с. 68], то может возникнуть сомнение в городском статусе поселения. Но учитывая достаточно низкую плотность населения даже в центральных районах Сибирского ханства, где насчитывалось всего несколько тысяч жителей, трудно ожидать огромных по площади городов. Наши вычисления позволяют утверждать, что размеры укрепленной площадки Искера вполне соответствует рядовому древнерусскому городу [32, табл. 3]. И позднее в Сибири русские города XVII в. занимали совсем небольшую площадь. Например, территория Мангазеи с кремлем и посадом не превышала 2 га [8, с. 4].

Но не только внушительная площадь и оборонительные сооружения свидетельствуют о городском статусе столицы. До XXI в. достоверных данных о каменном строительстве на Искере приведено не было. В.Н. Пигнатти в своей статье упоминает о кирпичах: «По берегу ..., - много кирпича, ...; по всему этому слою везде торчат кости животных (изумительное обилие) и кирпичи» [25, с. 10-11]. В другом месте он описывает найденный в раскопе чувал, сложенный из кирпичей, правда, плохо обожженных [25, с. 13]. Из этого описание совсем не следует, что В.Н. Пигнатти действительно наблюдал большое число обломков кирпичей, так как и сейчас в культурном слое Искера при исследованиях и осмотрах встречается много фрагментов обожженной глины - остатков чувалов. Труба чувала делалась из жердей и обмазывалась глиной смешанной с навозом. При топке чувала глина обжигалась. И именно обожженные фрагменты чувалов и являются маркером, определяющим слой развитого и позднего средневековья в Тобольском Прииртышье. Судя по тексту статьи, В.Н. Пигнатти не различал куски обожжённой глины и собственно обломки кирпичей.

Более пристально нужно присмотреться к словам М.С. Знаменского, еще в 1891 г. критиковавшего поверхностное описание Искера Г.Ф. Миллером, на которое, как на свидетельство, ставящее под сомнение городской статус столицы Сибирского ханства, опираются Д.Н. Маслюженко и С.Ф. Татауров [19, c. 139]. М.С. Знаменский писал: «Очевидно, почтенный историк производил 
осмотр этой местности только наглядным образом, мы же имеем в руках обломки кирпичей большой величины, прекрасно обожженных так, что не худо было бы эту археологическую древность иметь нашим современным кирпичным заводчикам ...» $[11$, с. 3]. Здесь, безусловно, краевед имел в виду именно кирпич, так как даже современный (не говоря уже о дореволюционном) кирпич невозможно спутать с глиняной обмазкой чувала. Но вопрос так и остался открытым, так как их рисунков в альбоме М.С. Знаменского (хранящегося в России) нет, а в изданной в 1922 г. описи коллекции М.С. Знаменского, хранящейся в Хельсинки, о них есть только краткое упоминание «260-265. Кирпич и обломки кирпичей. № 260 обозначен как происходящий с Искера» [12, с. 366]. Поэтому собранный М.С. Знаменским материал не привлекал внимания исследователей вплоть до самого последнего времени.

Новые факты о возможном каменном строительстве на Искере появились в 2008 г., когда в одном из наших раскопов были найдены четыре небольших обломка кирпича, судить о реальных размерах которых было невозможно. Только осенью 2019 г. при сборах на отмели Иртыша под Искером нами были обнаружены остатки большеформатного кирпича, вполне характерного для каменного строительства Средней Азии. В этом же году в небольшом раскопе, исследованном нами, был обнаружен еще один небольшой обломок от аналогичного кирпича. Теперь мы имеем с городища Искер, если учитывать и находки М.С. Знаменского, два кирпича и десять обломков. Кирпичи хорошо обожжены, легко отличаются от обмазки чувалов. Таким образом, обнаруженные нами фрагменты большеформатных кирпичей (как надо полагать и находки М.С. Знаменского), безусловно, изготавливались и обжигались мастерами кирпичного дела и, скорее всего, из Средней Азии. Этот кирпич применялся в XVI в. для нужд каменного строительства на Искере. Кирпичная кладка производилась на глиняный раствор, вследствие чего такие сооружения легко разбирались. Вот поэтому и не обнаружил Г.Ф. Миллер, посетивший место расположения бывшей столицы спустя более 140 лет после ее запустения, остатков каменных строений на площади Искера [23, с. 134-135].

Одним из критериев, по которому судят о городском статусе поселения количество его жителей. Д.Н. Маслюженко и С.Ф. Татауров считают, что численность населения Искера была не более 300 человек [19, с. 141]. Конечно же, у нас нет прямых сведений о числе жителей Искера. Но некоторые наблюдения все же можно привести. Так на Искере разместился отряд Ермака, в котором насчитывалось по самым минимальным подсчетам более 500 взрослых мужчин. Сюда же пришли и еще 300 стрельцов князя Болховского [28, с. 203-237].

Сразу же ответим на предположение Р.Г. Скрынникова, что отряд Ермака зимовал не на Искере, а в Карачином городище на р. Тобол [28, с. 241-242]. Все попытки найти городок мурзы Карачи тюменскими археологами и омскими поисковиками окончились безрезультатно [4, с. 9; 20, с. 188], да и наши поиски культурного слоя позднесредневекового времени на площадке, указанной С.У. Ремезовым «как городище думного Карачи» [31, с. 48; 33, л. 11а], были безуспешными. Поэтому ссылка Р.Г. Скрынникова на С.У. Ремезова для доказательства своей версии [28, с. 242] не подтверждается результатами археологических исследований. Остров и старичное озеро Карачинское, отмеченное еще С.У. Ремезовым, существуют и по настоящее время, 
но укрепленного городка или просто культурного слоя XV-XVI вв. в месте, как указанном С.У. Ремезовым, так и в окрестностях с. Карачинского, нет. В то же время, на Искере найдено большое количество артефактов, относящихся ко времени пребывания здесь отряда Ермака (только свинцовых пуль обнаружено более 100).

Находящиеся в столице Сибирского ханства сотни казаков и стрельцов вполне успешно разместились на площади городища в стационарных жилых домах. А значит, таких построек было не менее 100, и, надо думать, на Искере проживало не менее 100 семей, или около 500 жителей. Такая численность вполне сопоставима с численностью первых русских городов Сибири, которые даже в XVII в. редко насчитывали более 1000 человек. Например, в Мангазее в период расцвета проживало чуть более 700 человек [6, с. 11].

О том, что на Искере постоянно проживало довольно многочисленное население, свидетельствует и мощный культурный слой на памятнике, содержащий огромное количество находок. Подавляющая часть артефактов представлена изделиями из металла, кости и стекла [34; 14]. И, если сравнивать только по этим категориям вещей, то количество находок, собранных с небольшого участка столицы Сибирского ханства, вполне сравнимо с количеством находок из культурного слоя русского города Мангазея [9, с. 12]. А это никак не соответствует высказанному исследователями положению, согласно которому Искер представлял собой временную кочевую ставку, жизнь на которой оживлялась в редкие приезды правителя.

Итак, по таким критериям как наличие сложных укреплений, общая площадь, каменное строительство, количество жителей - столица Сибирского ханства Искер вполне соответствуют статусу крупнейшего города в Сибири в конце XV-XVI вв.

Следующая группа аргументов Д.Н. Маслюженко и С.Ф. Татаурова касается уровня развития торговли в столице Сибирского ханства. Исследователи считают, что Искер не мог существовать как торговый центр, так как располагался севернее торговых путей, а подходы к нему вдоль рек, впадающих в Иртыш, сильно заболочены, поэтому и Тобольск стал торговать со Средней Азией в XVII в. исключительно административными методами. Правитель Сибирского ханства Кучум эпизодически приезжал в Искер с торговым караваном, и во время нахождения хана и сбора им ясака, осуществлялась и торговля (подобно выездным русским ярмаркам) [19, с. 142].

Да, Искер расположен в зоне южной тайги и его окружают хвойные леса, растущие по берегам рек. Болота же возникают как раз вдали от русел рек, и это связано со слабо развитой речной сетью. При этом Искер как раз и расположен на наиболее удобном пути из Средней Азии в таежную зону Западной Сибири. Именно Искер позволяет контролировать торговлю с севером. Пути по рекам Тоболу и Ишиму сходятся у Искера. Пожалуй, самый короткий путь, из Средней Азии, шел по р. Ишим из глубины казахстанских степей с переходом в северной лесостепи на р. Вагай. Здесь, в самом узком месте, от p. Ишим до р. Емец, впадающей в р. Вагай, всего чуть более 60 км. А от северных лесостепных участков р. Вагай, вдоль берегов этой реки, поросшей тайгой, до ее устья - всего лишь чуть более 100 км. А по труднопроходимым таежным берегам Ишима и Иртыша до устья р. Вагая - около 220 км, а по поросшему хвойной лесом берегу р. Тобол до его устья - более 170 км, а по 
p. Иртыш (от устья р. Тары) до устья р. Вагай - около 360 км. Понятно, почему именно на р. Вагай пошел встречать торговый караван Ермак, и в ее устье он и принял последний свой бой $[17$, л. 28]. Эта дорога, получившая название Ишимской, была популярна и в XVII в. [21, с. 99-100].

В XVII в. среднеазиатским купцам, наверное, было несколько проще распродавать товары в расположенных к ним ближе, чем Тобольск, русских городах Тюмени и Таре (правда, в ограниченных объемах [10, с. 179]). А в каких центрах, расположенных на границе лесостепи и тайги, могли распродаваться бухарские товары в конце XV-XVI вв.? Если взглянуть на факты, то и в XVII в. центром русско-бухарской торговли являлся Тобольск [10, с. 179]. Основная масса бухарских караванов приходила в Тобольск осенью. По подсчету О.Н. Вилкова, в сентябре - 21\%, октябре - 23,6\%, ноябре - $18 \%$; гораздо реже торговые караваны приходили в июле, августе, декабре, феврале и мае [10, с. 179]. Понятно, что именно осенние месяцы - наиболее удобное время для караванной торговли, что связано и с погодными условиями в казахстанских степях, и с благоприятнейшими условиями в западносибирской лесостепи и южной тайге, где в это время перестает свирепствовать гнус. Эти же месяцы были наиболее благоприятны для прихода среднеазиатских караванов и в конце XV-XVI веках. Но какой ясак можно собирать осенью? Только в ноябре охотники уходили в тайгу на промысел зверя. Осень - самая горячая пора и для заготовки охотниками и рыболовами припасов (птицы, рыбы, ягоды, орехов) на зиму. В этот период затруднены пути сообщения из таежной части Западной Сибири (только водный путь вверх по быстро текущему Иртышу). Сентябрь-октябрь - наименее благоприятные месяцы для проведения широкой торговли среди рядового населения как Сибирского ханства (а у сибирских татар была достаточно большая доля присваивающих отраслей в хозяйственных занятиях [7, с. 80]), так и с угорским населением таежной части Западной Сибири.

Приходя осенью с караванами в Искер, среднеазиатские купцы, занимавшиеся оптовыми поставками на сибирский рынок, должны были быстро распродать свой товар в обмен на значительное количество сибирских товаров, пользовавшихся спросом на рынках Средней Азии. Но как на Искере за короткий отрезок времен можно было в розницу продать и приобрести большое количество товаров? Конечно, определенная часть пушнины сосредотачивалась в ханской казне как ясак, но эта была меньшая часть, чем оставалась на руках даже у сибирских татар, а обложение большим ясаком таежников просто невозможно: его можно силой собрать один раз. На следующий год найти таежного охотника просто не получится. Торговля же с севером позволяла получать баснословные барыши, как это и происходило вплоть до начала XX века. Поэтому естественный ход событий должен был привести к складыванию категории местных купцов, проживавших на Искере. Это могли быть как предприимчивые люди из сибирских татар, так и постоянно здесь проживавшие бухарские купцы.

Именно местные купцы, ведя круглогодичную мелкооптовую и розничную торговлю, накапливали при этом основные партии сибирских товаров, которые затем, при приходе караванов, выменивали их на изделия восточных купцов. Только они могли быстро скупить большие партии товаров с востока в обмен на товары из Сибири. 
Что же за изделия поступали в Сибирь из Средней Азии? В XVII в., по подсчетам О.Н. Вилкова, это были изделия 90 наименований. На долю среднеазиатских товаров приходилось 47 наименований, из которых 38 - это ткани, одежда и выделанные меха и кожи. Кроме того, поставлялись бумага, шелк-сырец, корица, бадьян, ревень, луки бухарские, котлы, одекуй. Кроме того, купцы привозили калмыцкие товары 28 видов: выделанные меха и кожи, одежда и скот, арканы и ясырь. Китайские товары 12 видов - ткань, одежда и чай, и 2 вида ткани и одежды арабские [10, с. 184-185]. Как мы видим, в XVII в. в Сибирь поставлялись в подавляющем большинстве ткани, одежда и выделанные кожи. Из Сибири же купцы увозили больше всего «мягкой рухляди» и меховой одежды, второе место по стоимости, занимали кожи, третье - сукна английские, гамбурские, сермяжные. Бухарские купцы покупали металлические изделия: медные котлы, железные топоры, оловянные пуговицы, иголки, медные серьги, сабли. Кроме того - бобровую и кабаргиную струю, саадаки, деревянные блюда и братины, «ясырей» [10, с. 197-198].

Опираясь на известную по письменным источникам номенклатуру поставок и покупок среднеазиатских купцов, попробуем разобраться с торговлей в Сибирском ханстве. Понятно, что и в конце XV-XVI вв. главным товаром, который привозили среднеазиатские купцы, были ткани и одежда. Розничная торговля тканями предполагает раскройку привезенных «концов» (последние могли достигать до 80 аршин [10, с. 187]), и на Искере частой находкой являются железные ножницы. Только в коллекции М.С. Знаменского их 12 экз. [34, с. 26], а в коллекции Тобольского музея-заповедника - 18 экз. [14, с. 122]. О широкой торговле тканями свидетельствуют и 29 свинцовых западноевропейских пломб, обнаруженных на Искере [1, с. 296]. Именно этими пломбами опечатывались тюки, которые поставлялись в Искер большими партиями, и здесь местные купцы, срывая пломбы, осуществляли розничную торговлю. Но откуда в Искер поставляли западноевропейские ткани? Через Среднюю Азию. Но почему тогда в XVII вв. именно западноевропейские ткани бухарские купцы закупали в Сибири?

Другим важным товаром, поставлявшимся в Сибирь, являлась металлическая посуда. Обломки чугунных котлов достаточно часто встречаются на Искере $[14$, с. 233]. Известны находки фрагментов медных и бронзовых чаш и остатков кувшинов [14, с. 236-242], которые, можно предполагать, поставлялись именно из Средней Азии. Можно было бы предположить, что и медные котлы, обломков которых найдено на Искере огромное число, поставлялись в Сибирское ханство из Средней Азии, но в XVII в. бухарцы, медные котлы, наоборот, в Сибири закупали, хотя и в ограниченных количествах. Вызывает удивление и тот факт, что бухарцы в XVII в. не только не привозили в Сибирь металлические украшения и пуговицы, но, наоборот, закупали их в Сибири.

Привозили бухарские купцы и китайские товары. Это, конечно же, не только ткани, но и, как свидетельствуют археологические находки, престижная посуда - китайский фарфор. Обломки фарфоровых изделий известны как в коллекции М.С. Знаменского, так и в коллекции Тобольского музея заповедника [14, рис. 25]. В материалах из нашего раскопа 2007 г. имеется и железный ключ к навесному замку, изготовленному, судя по всему, китайскими кузнецами, который принципиально отличается от восточноевропейских навесных замков, достаточно часто встречающихся в материалах Искера. 
Ишимская дорога была не единственной, по которой велась караванная торговля с Сибирью. По всей видимости, вдоль Тобола, обходя Уральские горы, шли купцы из Казанского и Астраханского ханств. Возможно, именно через них в Искер поставлялись западноевропейские ткани. Надо думать, именно таким путем в Сибирь поступали металлические пуговицы, медные перстни, зеркала, сундуки с железными замками и навесные замки [3, с. 55].

О том, что на Искере осуществлялись развитые торговые операции, свидетельствуют и многочисленные монеты, обнаруженные на городище. Серебряные (3 экз.) и медные (17 экз.) - восточные, судя по всему, из Средней Азии; и 74 серебряные (копейки, мечевые копейки, денги) - русские, Ивана IV. При этом подавляющая их часть использовались как платежные средства, и лишь немногие в качестве украшений, о чем свидетельствуют единичные монеты с отверстиями [3, с. 57].

Еще одно предположение Д.Н. Маслюженко и С.Ф. Татаурова относятся к отрицанию Искера как ремесленного центра. Этот вывод авторы сделали, проанализировав изданные материалы из раскопок Искера [19, с. 142], высказав предположения, что имеющиеся находки (украшения, монеты, замки и прочее) были собраны казаками в качестве трофеев во время их нахождения в Искере [19, с. 143].

С этими утверждениями трудно согласиться, так как по Искеру, на момент выхода статьи, не было издано ни одной обобщающей монографии, а находок собрано более 4500. Понятно, что имеющиеся публикации не затрагивают всех категорий находок, но авторы, кроме того, ограничили этот круг, не рассматривая предметы из грандиозных сборов М.С. Знаменского 80-х годов XIX в., пусть и изданных только как краткий каталог [34]; не проанализировали каталог вещей по Искеру Тобольского губернского музея [26]. А ведь более 4500 артефактов - это лишь малая часть находок, которыми был насыщен культурный слой столицы Сибирского ханства. Ведь М.С. Знаменский свои примерно 2500 находок собирал в течение пяти лет, большей частью на узкой (примерно 20-30 м) полосе береговой отмели р. Иртыш. Тогда от площадки городища Искер остался совсем небольшой участок, шириной чуть более 30 м [25, с. 7]. Именно с этого участка памятника получены предметы из сборов тобольских краеведов конца XIX - начала XX вв., в том числе и из раскопок В.Н. Пигнатти. Всего 1416 экз. по подсчетам последнего [26, c. 4]. Находки из раскопок А.П. Зыкова [13] и находки из раскопок и сборов начала XXI в. автора.

Возникает вопрос: так что же, все эти находки были собраны и выброшены в столице казаками Ермака за годы их пребывания в Сибири? Возьмем только одну категорию артефактов - обувные подковки. В коллекции М.С. Знаменского их 57 [34, с. 26], а среди находок Тобольского музеязаповедника - 32 [14, с. 357]. И как эта массовая категория артефактов могла попасть в культурный слой всего за 3 года пребывания казаков Ермака? А множество других бытовых предметов, большей частью поломанных, трудно представить воинской добычей. В то же время они составляют естественный набор любого археологического памятника, существовавшего продолжительное время.

Ханский двор, воины, купцы нуждались в сложных изделиях, отражающих специфику материальной культуры жителей Сибирского ханства. Мно- 
гочисленные отходы черного и цветного металла, литейные формы, долота, бракованные отливки, шилья, железные подковки для сапог, железные ножницы свидетельствуют, что на Искере проживали кузнецы, литейщики, портные и кожевенники, ювелиры. Натуральное хозяйство и торговля не могли обеспечить широкий набор предметов, необходимых для удовлетворения всех потребностей населения Сибирского ханства, а также и таежных охотников и рыболовов. О том, что в Сибирском ханстве было развито кузнечное производство, напрямую свидетельствуют обнаруженные на Искере, и нигде более не встречающиеся, железные обувные подковки, крепившиеся на загнутые носки сапог [3, с. 118]. Судя по всему, местные кузнецы изготавливали и железные замки для деревянных сундуков.

Отрицают авторы и значение Искера как религиозного центра. Но основным аргументом этого отрицания является лишь то, что остатки мечети не были обнаружены на городище. Кроме того, по мнению Д.Н. Маслюженко и С.Ф. Татаурова, здесь не было ни многочисленного населения, ни мусульманской общины [19, с. 143]. Да, у нас нет бесспорных данных о том, что в столице Сибирского ханства существовала мечеть, а вывод об отсутствии постоянного населения уважаемые авторы сделали сами, основываясь на поверхностном анализе ограниченного числа фактов. А если рассматривать всю совокупность имеющихся материалов, то Искер предстает как самое крупное в Сибири поселение с постоянно проживающими здесь купцами, ремесленниками, воинами, ханской семьей вместе с обслугой ханского двора. И поэтому сомневаться в том, в крупнейшем для Сибирского ханства поселении была мечеть, было бы недальновидно. Тем более, что конкретные данные о присутствии именно на Искере мусульманского духовенства приведены в работе Д.М. Исхакова и 3.А. Тычинских [15, с. 23]. Мечеть, кроме отправления религиозных обрядов, это и место распространения знаний, а просвещение невозможно без книг. А на Искере известны находки, которые можно интерпретировать как застежки от книг.

Обобщая сказанное, можно констатировать, что имеющиеся факты позволяют рассматривать столицу Сибирского ханства как крупнейший (для Сибири) город. Хорошо укрепленная столица, имевшая построенные из кирпича здания, существовала как постоянное поселение сибирских татар по крайне мере с конца XV по конец XVI вв. Это был политический, торговый, ремесленный и религиозный центр сибирских татар. Археологический контекст не позволяет считать городище Искер кратковременной ставкой сибирских ханов. 


\section{СПИСОК ЛИТЕРАТУРЫ}

1. Адамов А.А. Археологические исследования на Кучумовом городище (Искере) в 2014 году // Поволжская Археология. 2015. № 4 (14). С. 291-300.

2. Адамов A.A. Метрические характеристики Кучумово городища: анализ источников и реконструкция // Баландинские чтения. 2018. Т. 13. № 1. С. 105-110.

3. Адамов А.А., Балюнов И.В., Данилов П.Г. Город Тобольск. Археологический очерк. Тобольск: Типография ООО «Западно-Сибирская консалтинговая компания», 2008. $114 \mathrm{c}$.

4. Алиева T.A. В поисках городка мурзы Карачи // Присоединение Сибири к России: новые данные: материалы Всероссийской научно-практической конференции с международным участием. Тюмень: Издательство Тюменского государственного университета, 2014. С. 6-10.

5. Белич И.В. Чертеж «Кучумово городище и Старая Сибирь» из «Хорографической чертежной книги» С.У. Ремезова. К 300-летию составления первого русского географического атласа Сибири // Вестник археологии, антропологии и этнографии. 2010. № 1 (12). С. 141-155.

6. Белов М.И., Овсянников О.В., Старков В.Ф. Мангазея. Материальная культура русских полярных мореходов и землепроходцев XVI-XVII вв.: В 2 ч. М.: Наука, 1981. Ч. $2.148 \mathrm{c}$.

7. Валеев Ф.Т. Сибирские татары: культура и быт. Казань: Татарское книжное издательство, 1993. 208 с.

8. Визгалов Г.П., Пархимович С.Г. Мангазея - первый русский город в Сибирском Заполярье (по материалам раскопок 2001-2004 гг.). Нефтеюганск-Екатеринбург: Баско, 2007. 320 с.

9. Визгалов Г.П., Пархимович С.Г. Мангазея: новые археологические исследования (материалы 2001-2004 гг.). Екатеринбург-Нефтеюганск: Издательство «Магеллан», 2008. 296 с.

10. Вилков О.Н. Очерки социально-экономического развития Сибири конца XVIначала XVIII в. Новосибирск: Наука, 1990. 368 с.

11. Знаменский М.С. Искер. Тобольск: Типография Тобольского губернского правления, $1891.27 \mathrm{c.}$

12. Зыков А.П. Археологическая коллекция М.С. Знаменского с городища Искер // Ханты-Мансийский автономный округ в зеркале прошлого. Томск; ХантыМансийск: Издательство Томского университета, 2014. Вып. 12. С. 336-378.

13. Зыков А.П. Итоги раскопок 1988 и 1993 гг. городища Искер // Сибирский сборник: сборник статей. Курган, 2015. Вып. 3. С. 18-33.

14. Зыков А. П., Косинцев П. А., Трепавлов В.В. Город Сибир - городище Искер (историко-археологическое исследование). М.: Наука; Восточная литература, 2017. $559 \mathrm{c}$.

15. Исхаков Д.М., Тычинских 3.А. К вопросу о политическом статусе Искера // Историко-культурное наследие татар и сибирских татар Тюменской области: материалы научно-практической конференции, Тюмень-Тобольск, 22-23 сентября 2017 г. Тюмень: Издательство Тюменского государственного университета, 2017. С. 20-26.

16. Коновалова E.Н. Карты земли Тюменской XVI - начала XX вв.: очерки. Тюмень: Тюменский государственный нефтегазовый университет, 2015. 494 с.

17. Краткая Сибирская летопись (Кунгурская) со 154 рисунками / Пелевин Ю.А. (ред.). СПб.: Типография Ф.Г. Елеонскаго и К, 1880.39 л. +48 стб.

18. Кызласов Л.Р. Письменные известия о древних городах Сибири. М., 1992. $136 \mathrm{c}$.

19. Маслюженко Д.Н., Татауров С.Ф. Искер как мифологема в изучении истории Сибирского ханства // Золотоордынское обозрение. 2015. №4. С. 135-150. 
20. Матвеев A.B. Города и городки // Тюменское и Сибирское ханства: коллективная монография. Казань: Издательство Казанского университета, 2018. C 185-202.

21. Матвеев А.В., Татауров С.Ф. Пути сообщения сибирских ханств // Вестник Омского университета. 2011. №3. С. 95-101.

22. Матвеев А.В., Татауров С.Ф. Сибирское ханство: военно-политические аспекты истории. Казань: Академия наук Республики Татарстан, 2012. 260 с.

23. Миллер Г.Ф. Описание сибирского царства. СПб.: При Императорской Академии Наук, 1750. 490 с.

24. Овчинникова Б.Б. Искер - Кучумово городище (археологические исследования 1968 года) // Поволжская археология. 2014. № 1 (7). С. 166-193.

25. Пигнатти B.H. Искер (Кучумово городище) // Ежегодник Тобольского губернского музея. 1915. Вып. 25. С. 1-36.

26. Пигнатти В.Н. Каталог коллекции находок на Искре принадлежащей Тобольскому Губернскому Музею // Ежегодник Тобольского губернского музея. Тобольск: Типография Епархиального Братства, 2016. Вып. XXVI. C. 1-90.

27. Полное собрание русских летописей, Т. 36: Сибирские летописи, Ч. 1: Группа Есиповской летописи. М.: Наука, 1987. 383 с. $319 \mathrm{c}$.

28. Скрынников Р.Г. Сибирская экспедиция Ермака. Новосибирск: Наука, 1986.

29. Соболев В.И. История сибирских ханств (по археологическим материалам). Новосибирск: Наука, 2008. 356 с.

30. Хлебникова T.A. Историческая топография Болгара // Великий Болгар. М.; Казань: Феория, 2013. С. 68-77.

31. Хорографическая чертежная книга Сибири С.У. Ремезова. Тобольск, 2011. $692 \mathrm{c}$.

32. Штыхов Г.В. Города Полоцкой земли (IX-XIII вв.). Минск: Наука и техника, 1978. $160 \mathrm{c}$.

33. Leo Bagrow Collection of Maps of Siberia, 1667-1726 (MS Russ 72) // Houghton Library, Harvard University. Режим доступа: http://pds.lib.harvard.edu/pds/view /18273155 (дата обращения: 14.02.2020).

34. Tallgren A.M. Catalogue de la collection de M. Znamenski: Antiquités de la Sibéria occidentale conservées au Musée national de Finlande // Suomen Muinais muistoyhdistyksen aikakauskirja. Helsinki, 1922. XXIX: 4. P. 2-29. Pl. I-VI. (In French)

Сведения об авторе: Александр Александрович Адамов - кандидат исторических наук, старший научный сотрудник Тобольской комплексной научной станции Уральского отделения Российской академии наук (626152, ул. Академика Осипова, 15, Тобольск, Российская Федерация). E-mail: adamowaa@yandex.ru

Поступила 23.01.2021 Принята к публикаџии 10.05.2021

Опубликована 29.06.2021

\section{REFERENCES}

1. Adamov A.A. Arkheologicheskie issledovaniya na Kuchumovom gorodishche (Iskere) v 2014 godu [Archaeological research at Kuchumovo hillfort (Isker) in 2014]. Povolzhskaya arkheologiya [The Volga Region Archaeology]. 2015, no. 4. (14), pp. 291300. (In Russian)

2. Adamov A.A. Metricheskie kharakteristiki Kuchumovo gorodishcha: analiz istochnikov i rekonstruktsiya [Metric characteristics of the ancient settlement of Kuchu- 
movo: Source analysis and reconstruction]. Balandinskie chteniya [The Balandin Readings]. 2018, vol. 13, no. 1, pp. 105-110. (In Russian)

3. Adamov A.A., Balyunov I.V., Danilov P.G. Gorod Tobol'sk. Arkheologicheskiy ocherk [The Town of Tobolsk. An Archaeological Sketch]. Tobol'sk: West Siberian Consulting Company, 2008. 114 p. (In Russian)

4. Alieva T.A. V poiskakh gorodka murzy Karachi [In search for the town of Karachi Mirza]. Prisoedinenie Sibiri $k$ Rossii: novye dannye: materialy Vserossiyskoy nauchnoprakticheskoy konferentsii s mezhdunarodnym uchastiem [The Accession of Siberia to Russia: New Data: Proceedings of the All-Russian Research and Practice Conference with International Participation]. Tyumen: Tyumen State University publishing house, 2014, pp. 6-10. (In Russian)

5. Belich I.V. Chertezh "Kuchumovo gorodishche i Staraya Sibir" iz "Khorograficheskoy chertezhnoy knigi" S.U. Remezova. K 300-letiyu sostavleniya pervogo russkogo geograficheskogo atlasa Sibiri [A drawing of "Kuchum Settlement and the Old Siberia" from "Cartographical sketch-book" by S.U. Remezov: The 300" Anniversary of the Compilation of the First Russian Geographical Atlas of Siberia]. Vestnik arkheologii, antropologii i etnografii [Bulletin of Archaeology, Anthropology, and Ethnography]. 2010, no. 1. (12), pp. 141-155. (In Russian)

6. Belov M.I., Ovsyannikov O.V., Starkov V.F. Mangazeya. Material'naya kul'tura russkikh polyarnykh morekhodov i zemleprokhodtsev XVI-XVII vv. [Mangazeya. The Material Culture of Russian Polar Explorers and Navigators in the sixteenth and seventeenth centuries]. Moscow: Nauka, 1981, vol. 2. 148 p. (In Russ.)

7. Valeev F.T. Sibirskie tatary: kul'tura i byt [Siberian Tatars: Culture and Life]. Kazan: Tatar book publishing house, 1993. 208 p. (In Russian)

8. Vizgalov G.P., Parkhimovich S.G. Mangazeya - pervyy russkiy gorod v Sibirskom Zapolyar'e (po materialam raskopok 2001-2004 gg.) [Mangazeya: The First Russian City in the Siberian Arctic (based on materials from excavations in 2001-2004)]. Nefteyugansk; Ekaterinburg: Basco, 2007. 320 p. (In Russian)

9. Vizgalov G.P., Parkhimovich S.G. Mangazeya: novye arkheologicheskie issledovaniya (materialy 2001-2004 gg.) [Mangazeya: New Archaeological Researches (materials of 2001-2004)]. Ekaterinburg; Nefteyugansk: Publishing house "Magalhães", 2008. 296 p. (In Russian)

10. Vilkov O.N. Ocherki sotsial'no-ekonomicheskogo razvitiya Sibiri kontsa XVInachala XVIII v. [Essays on Socio-economic Development of Siberia from the late sixteenth to early eighteenth century]. Novosibirsk: Nauka, 1990. 368 p. (In Russian)

11. Znamenskiy M.S. Isker [Isker]. Tobolsk: Printing house of the Tobolsk provincial government, 1891. 27 p. (In Russian)

12. Zykov A.P. Arkheologicheskaya kollektsiya M.S. Znamenskogo s gorodishcha Isker [Archaeological collection of M.S. Znamensky from Isker ancient settlement]. Khanty-Mansiyskiy avtonomnyy okrug v zerkale proshlogo [Khanty-Mansiysk Autonomous District in the Mirror of the Past]. Tomsk; Khanty-Mansiysk: Tomsk University Press, 2014, iss. 12, pp. 336-378. (In Russian)

13. Zykov A.P. Itogi raskopok 1988 i 1993 gg. gorodishcha Isker [Results of Isker ancient settlement's excavations in 1988 and 1993]. Sibirskiy sbornik: sbornik statey [Siberian Collection: Collection of Articles]. Kurgan, 2015, iss. 3, pp. 18-33. (In Russian)

14. Zykov A.P., Kosintsev P.A., Trepavlov V.V. Gorod Sibir - gorodishche Isker (istoriko-arkheologicheskoe issledovanie) [The Town of Sibir - Hillfort Isker (historical and archaeological research)]. Moscow: Nauka, 2017. 559 p. (In Russian)

15. Iskhakov D.M., Tychinskikh Z.A. K voprosu o politicheskom statuse Iskera [On the issue of political status of Isker]. Istoriko-kul'turnoe nasledie tatar i sibirskikh tatar 
Tyumenskoy oblasti: materialy nauchno-prakticheskoy konferentsii [The Historical and Cultural Heritage of Tatars and Siberian Tatars of the Tyumen Region: Proceedings of the Research and Practice Conference]. Tyumen; Tobolsk: Tyumen State University publishing house, 2017, pp. 20-26. (In Russian)

16. Konovalova E.N. Karty zemli Tyumenskoy XVI - nachala XX vv.: ocherki [Maps of the Tyumen Land from the sixteenth to early twentieth century: Essays]. Tyumen: Tyumen State Oil and Gas University, 2015. 494 p. (In Russian)

17. Kratkaya Sibirskaya letopis' (Kungurskaya) so 154 risunkami [Brief Siberian (Kungurian) Chronicle with 154 Illustrations]. St. Petersburg: Publishing house of F.G. Eleonsky, 1880. 29 fol. +48 col. (In Russian)

18. Kyzlasov L.R. Pis'mennye izvestiya o drevnikh gorodakh Sibiri [Records about Ancient Cities of Siberia]. Moscow, 1992. 136 p. (In Russian)

19. Maslyuzhenko D.N., Tataurov S.F. Isker kak mifologema $\mathrm{v}$ izuchenii istorii Sibirskogo khanstva [Isker as mythologem in the study of history of the Siberian khanate]. Zolotoordynskoe obozrenie=Golden Horde Review. 2015, no. 5, pp. 135-150.

20. Matveev A.V. Goroda i gorodki [Cities and Towns]. Tyumenskoe i Sibirskoe khanstva: kollektivnaya monografiya [The Tyumen and Siberian Khanates: Multi-authored Monograph]. Kazan: Kazan State University Publ., 2018, pp. 185-202. (In Russian)

21. Matveev A.V., Tataurov S.F. Puti soobshcheniya sibirskikh khanstv [Routes of communication of the Siberian Khanate]. Vestnik Omskogo universiteta [Bulletin of the Omsk State University]. 2011, no. 3, pp. 95-101. (In Russian)

22. Matveev A.V., Tataurov S.F. Sibirskoe khanstvo: voenno-politicheskie aspekty istorii [The Siberian Khanate: Political and Military Aspects of History]. Kazan: Tatarstan Academy of Sciences, 2012. 260 p. (In Russian)

23. Miller G.F. Opisanie sibirskogo tsarstva [Description of the Siberian Tsardom]. St. Petersburg: At the Imperial Academy of Sciences, 1750. 490 p. (In Russian)

24. Ovchinnikova B.B. Isker - Kuchumovo gorodishche (arkheologicheskie issledovaniya 1968 goda) [Isker - Kuchum's fortified settelment (archaeological research of 1968)]. Povolzhskaya arkheologiya [The Volga Region Archaeology]. 2014, no. 4. (7), pp. 166-193. (In Russian)

25. Pignatti V.N. Isker (Kuchumovo gorodishche) [Isker (Kuchum Khan's fortified settlement)]. Ezhegodnik Tobol'skogo gubernskogo muzeya [A Yearbook of the Tobolsk Provincial Museum]. Tobolsk, 1915, iss. 25, pp. 1-36. (In Russian)

26. Pignatti V.N. Katalog kollektsii nakhodok na Iskere prinadlezhashchey Tobol'skomu Gubernskomu Muzeyu [The catalogue of finds on Isker belonging to the Tobolsk Provincial Museum]. Ezhegodnik Tobol'skogo gubernskogo muzeya [A Yearbook of the Tobolsk Provincial Museum]. Tobolsk, 1916, iss. 26, pp. 1-90. (In Russian)

27. Polnoe sobranie russkikh letopisey: Sibirskie letopisi, Ch. 1: Gruppa Esipovskoy letopisi [Complete Collection of Russian Chronicles, Vol. 36: Siberian Chroni-cles, Part 1: The Group of Esipov Chronicle]. Moscow, 1987. 383 p. (In Old Russian)

28. Skrynnikov R.G. Sibirskaya ekspeditsiya Ermaka [Ermak's Siberian Expedition]. Novosibirsk, 1986. 319 p. (In Russian)

29. Sobolev V.I. Istoriya sibirskikh khanstv (po arkheologicheskim materialam) [The History of Siberian Khanates (on archaeological materials)]. Novosibirsk, 2008. 356 p. (In Russian)

30. Khlebnikova T.A. Istoricheskaya topografiya Bolgara [Historical topography of Bolgar]. Velikiy Bolgar [Great Bolgar]. Moscow; Kazan, 2013, pp. 68-77. (In Russian)

31. Khorograficheskaya chertezhnaya kniga Sibiri S.U. Remezova [Chorographic Drawing Book of Siberia by S.U. Remezov]. Tobolsk, 2011. 692 p. (In Russian) 
32. Shtykhov G.V. Goroda Polotskoy zemli (IX-XIII vv.) [Cities of the Polotsk Land (from the ninth to thirteenth century)]. Minsk, 1978. 160 p. (In Russian)

33. Leo Bagrow Collection of Maps of Siberia, 1667-1726 (MS Russ 72). Houghton Library, Harvard University. Available at: http://pds.lib.harvard.edu/pds/view/18273155 (accessed: 14.02.2020). (In Russian)

34. Tallgren A.M. Catalogue de la collection de M. Znamenski: Antiquités de la Sibéria occidentale conservées au Musée national de Finlande. Suomen Muinaismuistoyhdistyksen aikakauskirja. Helsinki, 1922, vol. 29, no. 4, pp. 1-29. (In French)

About the author: Aleksandr A. Adamov - Cand. Sci. (History), Senior Research Fellow, Tobolsk complex scientific station of the Ural Branch of the Russian Academy of Sciences (15, Academician Osipov Str., Tobolsk 626152, Russian Federation). E-mail: adamowaa@yandex.ru

Received January 23, 2021 Accepted for publication May 10, 2021 


\title{
«СИБИРСКОЕ ЦАРСТВО» КАК КОНЦЕПТ РУССКИХ ЛЕТОПИСЕЙ И ПОСОЛЬСКИХ ДОКУМЕНТОВ ВТОРОЙ ПОЛОВИНЫ ХVI ВЕКА
}

\author{
Д.Н. Маслюженко \\ Курганский государственный университет \\ Курган, Российская Федераџия \\ denmas13@yandex.ru
}

Цель исследования: выявить источники и этапы становления концепта «Сибирское царство» в русских летописях и посольских документах второй половины XVI в.

Материаль исследования: работа проведена на основе анализа опубликованных источников (летописи, посольские документы, грамоты и договора, записки путешественников, данные картографии).

Результаты и научная новизна исследования: в отечественной историографии к государствам Шибанидов на территории Западной Сибири традиционно применяется обобщающее название «Сибирское ханство», которое восходит к известному в русских источниках Сибирскому царству. Анализ письменных источников и картографии показывает то, что на протяжении XV - первой половины XVI века это понятие не применялось в каких-либо документах в отношении владений Шибанидов. Чаще всего они связывались с Турой или производным от него Тураном восточных или Тюменью русских авторов. По мере расширения политических интересов московских правителей за Уралом в соответствующих источниках появляется название «Сибирская земля», которую долгое время довольно точно отличали от соседней Тюмени. Только с 1563 года в ходе трехсторонних переговоров в Москве между представителями Шибанидов, Тайбугидов и Рюриковичей впервые Сибирь начинает связываться с царством, что свидетельствует и о расширении владений тюменских ханов к востоку, которое было признано в Московском государстве. После этого иные используемые наименования владений Шибанидов были забыты, а в некоторых случаях концепт «Сибирское царство» или «сибирский царь» начинают обращаться на более раннее время и применяться к тюменским ханам Ибрахиму и Кутлуку. Это обращение в прошлое создавали исторические примеры, которые могли быть использованы для обоснования исконности русского владения Сибирской землей.

Концепт «Сибирское царство» явно отражал интересы определенных московских политических кругов, поскольку позволял рассматривать хана Кучума как отступника, занявшего ранее вассальный от Москвы престол и не признавшего своей зависимости, что легализовало соответствующие военные действия. Разработанный московскими дипломатами концепт позволял поставить Сибирское ханство в один ряд с Казанским и Астраханским ханствами, присоединение которых могло рассматриваться не столько как необоснованная незаконная военная агрессия, сколько как реализация права на установление приемлемой для Москвы формы правления. Присоединение Сибирского ханства стало рассматриваться как возвращение исконных «вотчин» российского самодержца, право на которые ему досталось от древнерусских князей, но только если понимать, что сама идея древности этой власти была сформирована в Москве, причем не ранее 1570-х гг.

Таким образом, выбор названия «Сибирское ханство (царство)» для наименования шибанидских государств на юге Западной Сибири с исторической точки зрения отражает именно идеологию Московского государства, но имеет весьма малое отношение к тому, как могли называть это государство сами его правители, представите- 
ли иных постордынских государств или местного населения, для которых гораздо ближе был бы концепт «Тюменское ханство».

Ключевые слова: Шибаниды, Тюменское ханство, Сибирское ханство, Московское царство, Иван IV

Для цитирования: Маслюженко Д.Н. «Сибирское царство» как концепт русских летописей и посольских документов второй половины XVI в. // Золотоордынское обозрение. 2021. Т. 9, № 2. С. 374-394. DOI: 10.22378/2313-6197.2021-9-2.374394

\title{
THE "SIBERIAN TSARDOM" AS A CONCEPT IN RUSSIAN CHRONICLES AND AMBASSADORIAL DOCUMENTS OF THE SECOND HALF OF THE SIXTEENTH CENTURY
}

\author{
D.N. Maslyuzhenko
}

\author{
Kurgan State University \\ Kurgan, Russian Federation \\ denmas13@yandex.ru
}

\begin{abstract}
Research objectives: To detect sources and stages for the formation of the concept of the "Siberian Tsardom" in the Russian chronicles and ambassadorial documents from the second half of the sixteenth century.

Research materials: This work was carried out on the basis of the analysis of the published sources (chronicles, ambassadorial documents, charters and contracts, travelers' notes, cartographic data).

Results and novelty of the research: In the native historiography, the Shibanid states in the territory of Western Siberia are traditionally referred to as the "Siberian khanate", terminology which dates back to the famous "Siberian Tsardom" in the Russian sources. An analysis of the written sources and cartography shows that during the fifteenth and first half of the sixteenth century, this notion was not used in any documents in relation to the Shibanids' possessions. Such terms were most often connected with Tura or East Turan or Tyumen by the Russian authors. As the political interests of the Muscovite rulers expanded east of the Urals, the name "Siberian land" appears in the corresponding sources, which was quite clearly differentiated from neighboring Tyumen for a long time. Only in 1563, during tripartite negotiations of the representatives of the Shibanids, Taibugids, and Ruirikovichi in Moscow, did Siberia start to be connected with the tsardom. This, as well, demonstrates the enlargement of the possessions of Tyumen khans to the east, something which was recognized in the Muscovite State. Afterwards, other names of the Shibanids' possessions were forgotten and in some cases the concept of the "Siberian Tsardom" or "Siberian Khan" came to refer to some earlier time and to be used for the Tyumen khans, Ibrahim and Kutluk. This reference to the past was created from historical examples which could be used to justify the notion of original Russian possession of the Siberian land.

The concept of the "Siberian Tsardom" obviously reflected the interests of particular Muscovite political circles, because it allowed for the consideration of Kuchum Khan as a separatist who seized the throne which was previously in vassal dependence on Moscow, and likewise did not admit his dependence. This latter act legalized and justified the resulting military activities. This concept, elaborated by Moscow diplomats, justified the Siberian khanate being tied into a single category alongside the Kazan and Astrakhan khanates. Their accession could be considered not so much as an unjustified, illegal military aggres-
\end{abstract}


sion, but as an exercise of the right to establish an acceptable form of government for Moscow. The annexation of the Siberian khanate began to be seen as the return of original "fiefdoms" of the Russian sovereign, a right which he received from the old Russian dukes. However, we must understand that the idea of the longstanding tradition of this power was itself developed in Moscow no earlier than the 1570s.

Thus, the choice of the name of the "Siberian Khanate (Tsardom)" to define the Shibanid states in the south of Western Siberia reflects the ideology of the Muscovite State from a historic point of view. It had little to do with how its rulers, the representatives of other post-Horde states, and the resident population would call it; for them, the concept of the "Tyumen Khanate" was much closer.

Keywords: Shibanids, Tyumen khanate, Siberian khanate, Islam, Western Siberia, Moscow Tsardom, Ivan IV

For citation: Maslyuzhenko D.N. The "Siberian Tsardom" as a Concept in Russian Chronicles and Ambassadorial Documents of the second half of the sixteenth century. Zolotoordynskoe obozrenie=Golden Horde Review. 2021, vol. 9, no. 2, pp. 374-394. DOI: 10.22378/2313-6197.2021-9-2.374-394

В отечественной историографии к государствам Шибанидов на территории Западной Сибири традиционно чаще всего применяется единое название «Сибирское ханство (царство)». Именно по такому пути шел один из первых советских историков постордынского мира М.Г. Сафаргалиев, который писал о появлении Сибирского ханства на основе Сибирского юрта Золотой Орды в начале XV века [47, с. 471-473]. Отчасти это связано с удобством географической привязки, отчасти с тем, что многие авторы опираются именно на терминологию («Сибирское царство») русских источников второй половины XVI - начала XVII вв. Эта позиция хорошо резюмирована А.С. Зуевым в соответствующей статье для исторической энциклопедии Сибири: «СИБИРСКОЕ ЦАРСТВО, офиц. название татар. ханств на тер. Зап. Сибири - сначала Тюменского, затем Сибирского, применяемое в Моск. Руси в кон. XVXVI в.» [17, с. 99]. Именно в этом контексте возникают вопросы о том, для кого именно оно было официальным и использовалось ли за пределами русской (шире российской) политической и исторической традиций.

В отношении постордынских ханств в исторических исследованиях на данный момент нет единого концепта выбора их наименования. Многие дефиниции, скорее, относятся к традиционно сложившимся в рамках историографии, в том числе обусловленным источниками русского происхождения при отсутствии или малом количестве иных. Чаще всего выбор обусловлен названием столичного центра этого государства (Казанское, Астраханское, Бухарское, Хивинское, Ургенчское, отчасти Крымское), хотя имеются и иные варианты (по возможному реконструируемому самоназванию - Большая Орда). Для восточной части Дешта, где в большей степени сохранялась именно кочевая специфика государственности, что приводило к отсутствию четко определенного оседлого столичного центра при росте политической значимости орду-базара, характерен выбор наименования по политониму населения - Ногайская Орда, Узбекское ханство, Казахское ханство.

В отношении постордынской государственности на юге Западной Сибири используются разные варианты наименования: Узбекское, Тюменское или Сибирское ханство, причем они могут обозначать как отдельные этапы ста- 
новления единой политии, так и выполнять обобщающую функцию. Автор этой статьи, вслед за Ш.Ф. Мухамедьяровым [29, с. 132-136], считает возможным именовать всю совокупность государств Шибанидов на юге Западной Сибири Тюменским ханством по первому месту расположения престола, которое может с большой долей условности пониматься в качестве столичного центра, то есть г. Тюмень (татарское Чинги-тура). Хотя, если следовать именно специфике восточной части постордынского пространства, то не меньшее право на существование имело бы «Шибанское ханство», причем не только по названию правящей династии, но и по наименованию поддерживавшей их группы населения [59, с. 352-362]. Другое дело, что в таком случае под это название бы попадали и иные ханства в Центральной Азии во главе с представителями этой династии, что в очередной раз только бы запутывало ситуацию.

Известные нам правители юга Западной Сибири XV века, видимо, не считали себя и не именовались соседями именно сибирскими, хотя реконструировать это возможно, видимо, только на основании упоминаний в русских источниках. Например, хан Ибрахим (Ибак) назывался в различных летописях как царь «шибанский», «ногайский» или «казанский» [33, с. 203; 39, с. 95; 40 , с. $32 ; 49$, с. 29$]$.

Если допустить, что летописец отражал некие исторические реалии, а не только свои представления, то в таком случае первое могло бы отражать не только принадлежность к династии, но претензии на власть над всеми шибанскими владениями, возможное доминирование над иными представителями династии или поддержку населения с общим политонимом «шибаны». Остальные два были связаны с конкретными процедурами интронизации Ибрахима ногайской и казанской аристократией. В последнем случае хан не занимал казанский престол, а для соответствующей территориальной части титула оказалось достаточным проведение избрания группой казанской аристократии [56, с.101], которая в результате русско-казанского конфликта бежала в Тюмень в конце 1480-х гг. В летописных источниках, описывающих русский поход 1483 года в Западную Сибирь, с Ибрахимом, видимо, связывается «Тюмень», которую русские отряды обошли по Тавде по пути к Сибирской земле [22, с. 121]. В посольской переписке 1490 г. в грамоте Ямгурчи также говорилось, что «Алгазыя я не видал, с Ибраимом с царем к Тюмени поехал, от тех мест у Ибреима царя в Тюмени живет» [41, с. 33-34]. Возможное наличие территориальной приставки «тюменский» в титуле Ибрахима упоминается и в реконструированном перечне государственного архива России XVI века [15, с. 138, 196; см. также: 30, с. 23]. В Холмогорской летописи, написанной в конце 1550-х гг., его наследник Мамук указывается как «Иваков брат Тюменского» [38, с. 130], хотя сам он был шибанским и казанским ханом [33, с. 242-243]. Русский перечень начала XVI века «Татарским землям имена» также использует для владений Шибанидов в целом понятие «Шибаны» [20, с. 253], что близко к известным упоминаниям соответствующих групп населения как «шибанцев» или «шибанов» [39, с. 95].

Таким образом, для XV века считать правителей данной династии именно и только сибирскими ханами, а само ханство именовать аналогичным образом не совсем корректно с позиций синхронных источников. Н.М. Карамзин приводил цитату: «Кучюмом, сыном киргизского хана Муртазы, первым 
царем сибирским», хотя сам он был с летописцем не согласен и считал на основании грамоты 1597 года, что первым сибирским царем следует считать еще деда Кучума Ибака [21, с. 476]. Однако в случае с Кучумом действительно не все так очевидно: например, в письме в Москву от Хан-мирзы, сына Уруса, в 1578 году сохранилось титулование Кучума «тюменским и сибирским» ханом [43, с. 268-269], что дает основание говорить о двух землях (вилайетах) в составе его ханства при доминировании Тюмени, в том числе и как более связанной с династией Шибанидов.

Сам Кучум назывался ханом Турана или владетелем области Тура у некоторых восточных авторов [2, с. 102; 11, с. 37-38; 55, с. 259, 261]. Опять же выбор в качестве обобщающего названия «Туранское ханство» не совсем удачен. С одной стороны, он может быть обоснован отсылкой к местному наименованию Тюмени Чинги-турой (или иногда просто Турой), однако, с другой стороны, слишком явно отсылает к концепту противопоставления в персидской литературе «Иран и Туран», где Туран в целом - территория к северу от Амударьи, занятая кочевыми племенами. Можно согласится с В.В. Трепавловым: «Абу-л-Гази обозначил страну Кучума старинным персидским названием Туран; полагаю, что никаких оснований, кроме созвучия с Турой, у него для этого не имелось [57, с. 387].

При этом «престол Тура» у Кадыр Али-бека Джалаира - это третий по важности престол после Казани и Астрахани в титуле царя Борис Годунова [9, с. 543]. И это указание представляется принципиально важным: для бека, происходившего из окружения бывавшего в Сибири казахского царевича Ураз-Мухаммада, являвшегося пасынком Кучума [7, с. 375], престол историографического Сибирского ханства находился в Туре, то есть Чинги-туре. Насколько нам известно, название Тура не применялось к формальной столице Ахмад-Гирея и Кучума - Искеру как центру Искерского юрта из шежере сибирских шейхов [10, с. 200-202] или Сибири в качестве центра Сибирской земли русских летописей. В литературе существует мнение о том, что Искер в некоторых легендах могли называть Тобол-турой $[28$, с. $175 ; 57$, с. 386]. Однако, судя по работам тобольских исследователей, она более убедительно связывается с юртами Тоболтуринскими (современная д. Тоболтура в 45 км от Тобольска) [60, с. 136-139].

Тура периода Кучума явно была связана с Турой в источниках по истории конца XIV-XV века. Впервые она упоминается под названием Singui на карте Каталонского атласа 1375 г. [6, с. 152]. В «Дафтар-и Чингиз-наме» юртом Урус-хана (видимо, в 1370-е гг.) также являлась «Тура». По мнению И.А. Мустакимова, в 1419 г. сыновья мангытского бия Эдиге Кейкубад и Нур ад-Дин «ушли в вилайет Тура и поселились среди народа под названием башкурд» [28, с. 172-173]. Возведенный Эдиге на престол в 1419 г., ХаджиМухаммад, от которого произошла династия тюменских ханов Шибанидов, в 1420-х гг. захватил «Шехр-и Тура» с расположенными вокруг него уже «мангытскими селениями» [26, с. 65]. А.-3. Валиди-Тоган по данным Утемишахаджи указывает, что другой шибанидский хан конца 1420-х гг. МахмудХоджа в союзе с родами Туранского вилайета воевал против конгратов и салджиутов $[11$, с. 40]. Таким образом, на протяжении нескольких десятилетий периода Великой Замятни и распада Улуса Джучи роль Туры на сибирском политическом пространстве значительно выросла. 
Явное указание на политическую значимость Туры имеется у Кухистани, описывающего приход к власти в 1430 г. в этом городе узбекского хана Абу-лХайра и предшествующее владение им представителями буркутов. Статус этого города в сибирских владениях Шибанидов предопределил выбор его в качестве «местопребывания трона государства и средоточия божьей помощи» [23, c. 143-144]. При этом еще в 1635 г. «вилайет Тура» упоминается в контексте послания поволжских татар в Крымское ханство с целью через поддержку турецкого султана подтолкнуть хана Джанибек-Гирея к походу в Среднее Поволжье против русских [19, с. 50-52]. Таким образом, Тура (Чинги-тура) могла отражать именно тюрко-татарскую историческую и политическую традицию наименования местной государственности Шибанидов, которая успешно соотносится именно с Тюменским ханством с центром в этом городе. Тура, побывав в руках Тука-Тимуридов, затем перешла под контроль мангытов Эдигеевичей, от них - к буркутским князьям Тайбугидам и затем Шибанидам. Только в одном восточном произведении Абд ал-Кадира ибн Мухаммад-Амина «Маджма ал-ансаб ва-л-ашджар» все ханы от Хаджи-Мухаммада до Ишима названы сибирскими, что связывается именно с названием их столицы [1, с. 275-276], однако само это сочинение написано в Бухаре только в конце 1890-х гг., когда реальная роль Чинги-туры, видимо, была полностью забыта.

Симптоматично, что значимость тюменского владения продолжала осознаваться татарскими информаторами русских летописцев еще в конце XVI начале XVII вв. Так, в Строгановской летописи указано «...в Сибирскую землю, и оттоле старейшинство прият называтися Тура» [50, с. 59]. В «Истории Сибирской» С.У. Ремезова, заложившей основы многим фантомам сибирской истории, в перечне т.н. «ишимских ханов», к генеалогии которых привязана династия Тайбугидов (именно в этом источнике они из князей превращаются в царей), их противник «Чингыз» также назван «царь тюменской» [46, с. 551]. В конечном итоге и в Румянцевском летописце фиксируется своеобразное старшинство Туры и для князей Тайбугидов: «На рецы же Обе царь некий бе Моаметева закона, именем Он, и убиен бысть. У него же бе сын Тайбуга. Сей прииде на реку Туру и созда град и нарече Чингиден» [40, с. 32].

Аналогичные указания на доминирующую роль Тюмени мы можем косвенно зафиксировать и в некоторых картографических источниках. Так, на западноевропейских картах А. Вида, А. Дженкинсона, С. Герберштейна, созданных между 1537-1562 гг., выделяется только «Тumen» (Тюмень) как обозначение отдельной земли с указанием города как «Tumen Wilky», при этом Сибирь здесь либо вообще отсутствует, либо обозначает просто город [24, рис.VI, IX, XVII]. В известных «Записках о Московии» С. Герберштейна указывается, что «... поблизости находится царство Тюмень, государь которого татарин и на их родном языке называется Tumenski czar, т.е. тюменским царем (rex in Tumen)» [13, c. 161]. При этом Тюменью могли обозначать все степи за Волгой (например, на карте А. Дженкинсона). Хотя на картах Батиста Аньезе 1525 г. и Джакомо Гасталди 1548 г. нет указания Тюмени, зато практически это место занимает «Scinbani Tartari», то есть Шибанские татары $[63$, с. $173 ; 64$, с. 88-89], земли которых занимали значительную часть степей за Уралом. В целом это еще раз сближает Тюмень и Шибаны в едином территориальном и политическом контексте. Утрата Чинги-турой ее былого значения становится заметна только на картах последней трети XVI века. На карте 
Г. Меркатора 1594 г. Tumen и Sibior впервые выделяются как отдельные земли с двумя соответствующими городами [24, рис. XXIV]. На картах А. Ортелия (1570 г.) и Й. Хондиуса (1606 г.) уже фиксируется «Zibierairorum Horda», то есть искаженное «Орда сибирских татар» [58, с. 124; 64, с. 90], которая располагалась в степях к северу от Туркестана и Мавераннахра.

В конечном итоге Чинги-тура (Тюмень) попала и в поле зрения русских летописцев, которые впервые отметили этот город в контексте поражения и убийства в 1406 году близ него хана Токтамыша от рук Шадибека [39, с. 82]. При этом проведенная здесь замена татарской Чинги-туры или просто Туры на Тюмень требует отдельного объяснения. Еще в 1965 г. Э.Л. Кинан в качестве одного из «традиционных престольных мест суверенной власти» также называл именно Тюмень в Сибири [66, с. 74]. Исходя из этого, необходимо уточнить хронологию и понять причины, которые привели к формированию концепта «Сибирское царство» в русских источниках, а, следовательно, и закреплению за соответствующими правителями из Шибанидов титула «сибирского царя».

Резюмируя все вышесказанное, еще раз отметим, что фактически в восточных и западных источниках нет связи между правителями династии Шибанидов XV века и собственно Сибирью. Впервые указание на сибирские владения Шибанидов появляется только в наименовании в 1505/6 г. сына тюменского хана Ибрахима Кутлука «сибирским царем» из Тюмени: «Лета 7014 пришедши из Тюмени на Великую Пермь ратью сибирский царь Кулуг Салтан и без вести приступиша» [12, с. 264]; то есть это был сибирский хан из Чинги-Туры. С исторической точки зрения логично было бы предложить, что за несколько лет до этого в результате деятельности Тайбугидов в состав Тюменского ханства вошла ранее независимая Сибирская земля. Однако саму Вычегодско-Вымскую летопись начал вести только в конце XVI века основатель Усть-Вымской Архангельской пустыни Мисаил, который опирался при этом на «жития» пермских епископов, великокняжеские и царские грамоты. Также он использовал материалы Устюжской и некоторых других летописей, в том числе не дошедшей до нас Пермской владычной летописи [12, с. 257]. Следовательно, объяснение указания здесь на Кутлука как на сибирского царя надо искать в контексте некоей сложившейся традиции конца XVI века.

Интересно, что совместное указание Сибири и Тюмени имеется и в Архангелогородском летописце первой четверти XVI века, хотя и в ином контексте: «... тое же зимы царь Женибек (Шадибек) уби Тактамыша в Сибирскои земле близ Тюмени» [39, с. 82]. Таким образом, в этом описании события Тюмень также рассматривалась как часть Сибирской земли, возможно, даже как ее столичный центр. Однако уже относительно похода 1483 года в той же летописи Тюмень и Сибирь становятся двумя отдельными землями: «А воиводы великого князя оттоле пошли по Тавде реце мимо Тюмень в Сибирь. И Сибирьскую землю воевали, идучи, добра и полону взяли много» [39, c. 49]. А.А. Горский указывает на то, что в русском летописании «землями» именовались независимые государства [14, с. 80].

На данный момент на основании источников невозможно реконструировать тот момент, когда Тюмень и Сибирь перестали восприниматься как единое целое, поскольку слишком уникальный характер носят любые упоминания событий в Сибири в XV веке в русских летописях. Теоретически возможно, что 
это произошло в период становления Тюменского ханства в 1420-е г., когда интересы Шибанидов были связаны именно со степной политикой. Это позволило к северу от них начать укрепляться отдельным угорским княжествам, под контролем которых мог оказаться и Искер (Сибирь). Обратим внимание на еще один поздний документ - грамоту к царю Федору Ивановичу от сибирского Байсеит-мурзы в 1597 году. Несмотря на совместное нахождение в течение более 30 лет под властью ханов Ахмад-Гирея и Кучума, в документе прослеживается возможное сохраняющееся противопоставление Сибири и Тюмени: «... Сибирские земли все от мала до велика холопы твои челом бьют. Мы по своей правде воеводам послушны, а Тюменские люди отложились...» [51, с. 129].

Таким образом, во-первых, в северной (поморской) традиции летописания прослеживается эволюция от Тюмени как части или центра Сибири до их разделения на две земли, что может быть связано со становлением Тюменского ханства. Во-вторых, применительно к событиям XV - начала XVI века в этой же традиции летописания, как собственно и московской, Сибирская земля до определенного времени не связывалась с ханами из Шибанидов. При этом справедливо возникает вопрос о том, откуда русские летописцы узнали само название Сибирь. Еще Г.Ф. Миллер считал, что «имя же Сибирь произошло в России чаятельно от такого народа, который о сей земле первую ведомость подал, а именно по моему мнению от Пермяков или от Зырян» [25, с. 38]. В принципе это хорошо бы увязывалось с происхождением тех летописей, где чаще упоминается Сибирская земля. Однако известие об убийстве Токтамыша, в контексте которого впервые указана Сибирь, встречается также в связанных друг с другом Симеоновской летописи [35, с. 153], Московском летописном своде [36, с. 236], Вологодско-Пермской летописи [37, с. 174], хотя и без указания Тюмени. Более ранние указания на Сибирь (или «Сибирь и Ибирь») известны нам по монгольским [52, с. 123-124] или арабским источникам (альОмари ад-Димашки), а также запискам путешественников (Иоганка) XIII-XIV века, которые в целом указывают на связь этого названия с монгольским миром [5, с. 91; 16, с. 106-107]. То есть географическое или политическое понятие «Сибирь» могло попасть в русские документы от тюркских или, шире, мусульманских информаторов. При этом обратим внимание на то, что в указанном выше перечне «Татарским землям имена» понятие «Сибирь» отсутствует. Одновременно с этим возникает историко-географическая проблема: что именно авторы XIII-XIV века понимали под Сибирью, была ли эта лишь территория в районе впадения Тобола в Иртыш (будущая Сибирская земля) или это было более глобальное понимание, близкое к современности? Понятно только то, что границы этой Сибири не были устойчивыми и варьировались по мере укрепления здесь правителей Улуса Джучи.

Впрочем, следует еще раз признать, что до 1555 года любые упоминания Сибирской земли в московском летописании не просто единичны, а по сути уникальны, и тем более не играют какой-то реально значимой идеологической роли. Исключением могло быть только упоминание князя Лятика в контексте результатов похода 1483 года. В летописях упоминается приход в составе посольства для принятия шерти к Ивану III «сибирских князей» (в Устюжском летописном своде) или «сибирского князя Лятика» (в позднем Архангелогородском летописце) [61, с. 49, 95]. Происхождение этого сообщения неизвестно, а в иных северных летописях данных об участии сибирских кня- 
зей в переговорах о подданстве после похода 1483 года нет. Скорее всего, можно согласиться с мнением А.И. Плигузова о том, что «это известие малодостоверно, ибо в ранних источниках речь идет о послах пелымских вогулов, а не о делегации “Сибирской земли”» [32, с. 153, прим. 32]. На наш взгляд, в этом отношении весьма заметно отсутствие упоминания этих князей в самой ранней Вологодско-Пермской летописи, составленной при дворе Филофея, казалось бы, заинтересованного в преувеличении результатов похода.

Ситуация кардинально меняется с приходом в Москву посольства от сибирского князя Едигера в январе 1555 года: «послы... от Сибирского князя Едигера и от всей земли Сибирской...» [34, с. 248]. По мнению исследователей, после этого по просьбе сибирского бека Едигера Иван IV «их князя и всю землю Сибирьскую взял во свое имя и от сторон ото всех заступил и дань свою на них положил...», а в царском титуле появились слова «всея Сибирские земли повелитель», которые заняли последнее место в перечислении земель территориального титула русских государей [42, с. 45; 44, с. 14]. Новое приобретение нашло отражение и в международной деятельности, где впервые встречается в грамоте Ивана IV турецкому султану от 20 июня 1555 года [62, с. 206]. В тексте проекта ответа посла в Литву С. Турпеева уже подробнее говорится, что «Сибирская земля по ряду с Казанскою землею; и как государь наш... взял Казань, и Сибирской князь Едигер бил челом государю нашему со всеми сибирскими людьми, чтобы царь... пожаловал, Сибирские земли держал за собою, и дань бы с них имал, а их бы с Сибирскые земли не сводил» [42, с. 45]. Обратим внимание на то, что речи еще не идет о связи между Сибирью и царством как таковым. По сути, в период переговоров между Москвой и Искером 1555-1563 г. в источниках сохраняется наименование «Сибирская земля».

Впервые Сибирь связывается с царской (ханской) властью только после трехсторонних переговоров в Москве между Иваном IV, князем Едигером Тайбугидом и Шибанидами Муртазой и Ахмад-Гиреем. В связи с этим интересно наименование документа: «Столпик Сибирской 7072 году (1563-64 гг.), привозу к Москве сибирсково Муртазы царя татарина Ташкина» [18, с.47]; как четко связывающего одного из Шибанидов с титулом сибирского царя. Несмотря на дальнейшее игнорирование роли сибирского хана Ахмад-Гирея в большинстве источников и исследовательских работах, во многом верна мысль С.У. Ремезова в «Истории сибирской»: «Царь Кучум прииде от казачьи орды со многими вои... и прославшася Сибирской царь и дани со многих низовых языке взял» [46, с. 552]. По сути, после воцарения Шибанидов в Искере в 1563 году они однозначно становятся для русских соседей именно сибирскими царями, а сама Сибирская земля становится Сибирским царством. Причем формируется новый концепт в течении некоторого времени. Очень емко об этом написал Дон Островски: «Ву the late $16^{\text {th }}$ century, the Tiumen Khanate was being called the Khanate of Sibir' in the Russian sources» [67, p. 1].

В непосредственных текстах грамот от самого Кучума указание на сибирскую территориальную принадлежность в его титуле не встречается. Например, в грамоте 1570 г. «Вольной человек Кочум царь», но при этом в заголовке, авторами которого могли быть служащие Посольского приказа, указано «Сибирского Царя Кучума» [51, с. 52]. Аналогично написано в отписке земских бояр царю Ивану IV в 1570 г. о том, что был отпущен посол в «Си- 
бирь, к Сибирскому царю» [4, с. 340]. Более принципиальным было обращение на титул именно сибирского царя у Кучума в переговорах 1571 года, в рамках которых предполагалось подписание шертной грамоты ханом и лучшими сибирскими людьми. Условием шерти было то, что «государь нас пожаловал, и землю Сибирскую в своем жаловании учинил, и дань на Сибирскую землю положил...» [51, с. 63-65]. К 1570-1571 гг. в Посольском приказе, возможно, под непосредственным руководством дьяка А.Я. Щелкалова [3, c. 48], было выработано понимание того, что Кучум был именно сибирским царем и правил на престоле Сибирского царства.

Заняв новый для них престол в Искере (Сибири) братья Ахмад-Гирей и Кучум оказались в довольно сложной в плане международной политики ситуации, которой просто бы не возникло, если бы они остались в традиционном центре власти Шибанидов, то есть Чинги-туре. С позиций московского правителя, с которой в это время уже нельзя было не считаться, формально с 1555 года Сибирская земля была в русском подданстве. Новые правители Сибири были вынуждены либо идти на прямой разрыв, что могли бы сделать Шибаниды, либо подтверждать это положение. При этом абсолютно не ясны причины именно второго выбора, хотя вполне возможно, что они были связаны с некими договоренностями в ходе переговоров в Москве.

Таким образом, связь Сибири с царством и царем фиксируется в русских источниках не ранее 1563 года. При этом иногда она начинает явно обращаться на более раннее время для доказательства исконности русского владения Сибирской землей. Напомним, что в Москве была хороша знакома фигура деда Кучума хана Ибрахима, в том числе как по причине столкновении интересов в Казани, так и в связи с его участием в убийстве хана Большой Орды Ахмада в январе 1481 года. В ранних документах Ибак нигде не связывался с сибирским престолом, но затем в грамоте царя Федора хану Кучуму в 1597 г. появляется фраза, которая свидетельствует о знакомстве готовивших письмо посольских специалистов с генеалогией правителя, но одновременно делающая уже Ибрахима сибирским ханом: «Из давних лет Сибирское государство была вотчина прародителей наших, Великих государей Русских царей, как еще на Сибирском государстве был дед твои Ибак Царь, и з Сибирские земли всякую дань давали нашим прародителям...» [51, с. 132]. Очевидно, эта новая версия хорошо вписывалась в уже сложившуюся к этому времени политическую традицию. Наверное, именно она могла найти отражение и в летописном упоминание сына Ибрахима Кутлука сибирским царем.

Русские дипломаты здесь использовали принятый как кочевниками, так и Москвой дипломатический прием: апелляция к авторитетным предкам. Причем часто могла подчеркиваться фиктивная, даже фальсифицированная, служба этих людей предкам московских государей. Подобные «исторические примеры сыграли абсолютную роль в обосновании прав Москвы на Казань и Астрахань» [27, с. 285-287]. По всей видимости, по этому же пути решили пойти и в случае с продолжавшим оказывать сопротивление Сибирским ханством. Еще в ноябре 1584 года в одном из наказов Лукьяну Новосильцеву указывалось: «преж сего на Сибирском царстве Цари бывали из рук государей наших и дань давали государям нашим; и нынешний Кучюм царь посаженник был отца государя нашего...» [31, с. 922]. В 1586 году в наказе приставам Е. Ржевскому и Г. Васильчикову, встречавшим польского посла, гово- 
рилось: «Сибирское царство искони вечная вотчина государей наших. А взял Сибирь ... царь и великий князь Иван Васильевич, царя и государя и великого князя Федора Ивановича прадед, тому ныне блиско ста лет...» [42, с. 49]. В наказе явно вспомнили об упоминании сибирского князя в контексте последствий похода 1483 года, в результате власть Москвы над Сибирью действительно по времени опустилась до периода правления хана Ибрахима.

Если обратиться к версии М.В. Моисеева, то основные черты концепции легитимации прав России на Джучидское наследие сложились в первой половине XVI века, оформились в 1555-1556 гг. и начали использоваться между 1563-1569 гг. [27, с. 288]. Представляется весьма важным, что период 15551556 гг. совпадает с переговорами о шерти сибирского князя Едигера, а 15631569 гг. - с переговорами с Кучумом по вопросам его подданства, которые должны были также завершиться подписанием шерти. Затем после 1584 года сложившаяся ранее концепция была доработана с учетом имевшихся исторических примеров, что привело к удревнению зависимости Сибири от Москвы.

При этом понятия «земля», «царство» и «государство» в документах постепенно становятся идентичными: «наши люди тебя с Царства согнали и Сибирскую землю взяли», «...на Сибирской земле Царем». Причем в них подчёркивалось: «Хотели тебя пожаловати, устроити на Сибирской земле царем...» [51, с. 133-134]. По сути, между 1563 и 1599 гг. сформировался однозначный концепт русской посольской документации, согласно которому земли хана Кучума за Уралом именуются Сибирью (после 1584 г. именно Сибирским царством или государством) и, что еще более важно, считаются собственностью русских царей, хотя и были при этом формально независимым автономным татарским юртом, как это правильно подчеркивает Б.Р. Рахимзянов [45, с. 138]. Причем концепты «Сибирское царство» и «сибирский царь», по всей видимости, существовали только в русской летописной традиции и связанной с ней посольской документации, если следовать версии М.В. Моисеева о соотношении данных документов по вопросу обоснования прав Москвы на Казань и Астрахань [27, с. 287]. Это наиболее заметно на примере отложившихся в ф.109 и ф.131 РГАДА документов переписки между бухарским ханом Абдаллахом II и Кучумом в 1595-1596 г. В них в русских заголовках Кучум указан именно царем Сибирским, в то время как в самом тексте письма указание на территориальный признак ханского титула отсутствует [8, с. 238-239].

Для синхронных татарских информаторов ситуация с очевидностью была иной. Кадыр Али-бек, создавая в Касимове около 1600 г. свой т.н. «татарский летописец», в посвящении царю Борису Годунову указывал занятые им престолы: «Хан, располагающий престолом Казани, престолом Астрахани, престолом Туры, престолом Сарайчика» [9, с. 546]. Однако в официальном царском титуле в мае 1599 г. к английской королеве Елизавете и в сентябре 1599 г. в документах посольства в Священную Римскую империю на третьем месте впервые появляется указание «Царь Сибирский» [44, с. 14; 54, с. 55]. Несмотря на периодические возвраты в грамотах к старому указанию на «всея Сибирской земли» [58, с. 70-71], это окончательно делало Сибирь частью Московского государства, по крайней мере, на уровне международной дипломатии. Уже в 1600 году послы в Англию должны были говорить: «Сибирское царство искони вечная отчина государей наших, царей Россий- 
ских...» [48, с. 296]. При этом там, где русские видели Сибирское царство, тюркские авторы и информаторы продолжали видеть престол Туры. После смерти Кучума около 1600 г. новым ханом стал его старший сын Али [58, с. 67-68]. Понятно, что с появлением в 1599 г. в титулатуре русского царя указания на «Царя Сибирского» и пленением хана Али в 1608 г. русская власть фактически перестает признавать иных потомков Кучума в качестве царей (исключением является однократное указание на наличие этого титула у брата Али Ишима).

Таким образом, концепт «Сибирское царство» явно отражал интересы определенных московских политических кругов, поскольку позволял рассматривать хана Кучума как отступника, занявшего ранее вассальный от Москвы престол и не признавшего своей зависимости [близки к этому мысли: 65 , с. 165], что легализовало соответствующие военные действия. В результате создания рассмотренного концепта Сибирское ханство стало возможным поставить в один ряд с Казанским и Астраханским ханствами, как это было воплощено уже в Есиповской летописи Титовского вида [53, с. 23]. Их присоединение могло рассматриваться не как фактор «необоснованной незаконной военной агрессии, а как реализации своего права на установление той формы управления которая представляется Москве приемлемой» [27, с. 299]. При этом отчасти прав и М. Акишин: «...в конце XV-XVI в. присоединение Сибирского ханства рассматривалось как возвращение исконных “вотчин” российского самодержца, право на которые ему досталось от древнерусских князей» [3, с. 54]. Но только если понимать, что сама идея древности этой власти была сформирована в Москве, причем не ранее 1570-х гг. Все эти размышления также показывают и то, что выбор названия «Сибирское ханство (царство)» для наименования шибанидских государств на юге Западной Сибири с исторической точки зрения отражает именно идеологию Московского государства, но имеет весьма малое отношение к тому, как могли называть это государство сами его правители, представители иных постордынских государств или местного населения, для которых гораздо ближе был бы концепт «Тюменское ханство».

\section{СПИСОК ЛИТЕРАТУРЫ}

1. Абд ал-Кадир ибн Мухаммад-Амин Маджма ал-ансаб ва-л-ашджар // История Казахстана в персидских источниках. Алматы: Дайк-Пресс, 2005. Т. II. 692 с.

2. Абуль-Гази-Бахадур-хан. Родословное древо тюрков / Саблуков Г.С. (пер.) // Абуль-Гази-Бахадур-хан. Родословное древо тюрков. Иоакинф. История первых четырех ханов дома Чингисова. Лэн-Пуль Стэнли. Мусульманские династии. М.; Ташкент; Баку, 1996. С. 3-186.

3. Акишин М. Дьяки Посольского приказа и присоединение Сибири // Российская история. 2015. № 3. С. 45-54.

4. Акты исторические, собранные и изданные Археографической комиссией, Т. 1: 1334-1598 гг. СПб.: Типография Экспедиции заготовления государственных бумаг, $1841.596 \mathrm{c.}$

5. Аннинский C.A. Известия венгерских миссионеров XIII-XIV вв. о татарах в Восточной Европе // Исторический архив. М.; Л.: Издательство Академии наук CCCP, 1940. T. III. C. 71-112. 
6. Белич И.В. К этимологии, семантике и истории происхождения средневекового имени г. Тюмень // Вестник археологии, антропологии и этнографии. 2007. № 7. C. $143-157$.

7. Беляков А.В. Царицы сибирские // Золотоордынское обозрение. 2019. Т. 7, № 2. C. 372-391. DOI: 10.22378/2313-6197.2019-7-2.372-391

8. Беляков А.В., Маслюженко Д.Н. Сибирско-бухарско-ногайские отношения в свете переписки бухарского хана Абдаллаха с сибирским ханом Кучумом // Stratum plus. 2016. № 6. С. 229-243.

9. Березин И.Н. Татарский летописец. Современник Борис Федоровича Годунова // Московитянин. 1851. № 24. Кн. 2. С. 540-554.

10. Бустанов А.К. Манускрипты суфийских шайхов: туркестанская традиция на берегах Иртыша // Этнографо-археологические комплексы: проблемы культуры и социума. Омск: Издательский дом «Наука», 2009. Т. 11. С. 195-229.

11. Валиди Тоган А. История башкир. Уфа: Китап, 2010. 352 с.

12. Вычегодско-Вымская (Мисаило-Евтихиевская) летопись // Историко-филологический сборник Коми филиала Академии наук СССР. Сыктывкар: Коми книжное издательство, 1958. Вып. 4. С. 241-270.

13. Герберштейн С. Записки о Московии / Янин В.Л. (ред.). М.: Издательство Московского университета, 1998. 420 с.

14. Горский А.А. Русь: От славянского расселения до Московского царства. М.: Языки славянской культуры, 2004. 368 с.

15. Государственный архив России XVI столетия. Опыт реконструкции / Зимин А.А., Черепнин Л.В. (ред.). М.: Институт истории СССР Академии наук СССР, 1978. Ч. $1.630 \mathrm{c}$.

16. Золотая Орда в источниках, Т. 1: Арабские и персидские сочинения / Храпачевский Р.П. (ред.). М.: ППП «Типография “Наука"», 2003. 448 с.

17. Зуев А.С. Сибирское царство // Историческая энциклопедия Сибири, Т. III: С-Я. Новосибирск: Издательский дом «Историческое наследие Сибири», Институт истории Сибирского отделения Российской Академии наук, 2009. С. 99.

18. Исхаков Д.М. О титуле «Сибирский князь» // Сулеймановские чтения: Материалы Х Всероссийской научно-практической конференции. Тюмень: СИТИ-пресс, 2007. C. $46-47$.

19. Исхаков Д.М. Об одном послании из Поволжья в Крымское ханство 1635 г. // Крымское историческое обозрение. 2014. № 2. С. 50-62.

20. Казакова Н.А. «Татарским землям имена» // Куликовская битва и подъем национального самосознания. Л.: Наука, 1979. С. 253-256.

21. Карамзин Н.М. История государства Российского. М.: РИПОЛ-КЛАССИК, 1998. Кн. 3. T. VII-IX. 592 с.

22. Маслюженко Д.Н., Рябинина Е.А. Поход 1483 г. и его место в истории русско-сибирских отношений // Вестник археологии, антропологии и этнографии. 2014. № 1 (24). С. 115-123.

23. Материалы по истории Казахских ханств XV-XVIII веков (извлечения из персидских и тюркских сочинений). Алма-Ата: Издательство «Наука» КазССР, 1969. $652 \mathrm{c}$.

24. Материалы по истории русской картографии, Вып. I: Карты всей России и южных ее областей до половины XVII века. Киев, 1899. 15 с. +32 табл.

25. Миллер Г.Ф. История Сибири. М.: Издательская фирма «Восточная литература» Российской Академии наук, 2005. Т. 1. 630 с.

26. Миргалеев И.М. Сообщение Продолжателя «Чингиз-наме» Утемиша-хаджи о поздних Шибанидах // История, экономика и культура средневековых тюркотатарских государств Западной Сибири. Материалы II Всероссийской научной конференции. Курган: Издательство Курганского государственного университета, 2014. C. 64-66. 
27. Моисеев М.В. Исторические примеры в посланиях Ивана IV в Крымское ханство и Ногайскую Орду // Золотоордынское обозрение. 2018. Т. 6, № 2. С. 284-303. DOI: $10.22378 / 2313-6197.2018-6-2.283-303$

28. Мустакимов И. Источники по истории владений Шибана и Шибанидов в золотоордынское время // История и культура татар Западной Сибири. Казань: Институт истории им. Ш. Маржани АН РТ, 2015. С. 168-177.

29. Мухамедьяров Ш.Ф. Тюменское ханство // Очерки истории исламской цивилизации. М.: Российская политическая энциклопедия, 2008. Т. 2. С. 132-136.

30. Описи царского архива XVI в. и архива Посольского приказа 1614 г. М.: Издательство восточной литературы, 1960. 195 с.

31. Памятники дипломатических сношений древней России с державами иностранными, Часть первая: Сношения с государствами европейскими. Памятники дипломатических сношений с Империей Римской, Т. I: С 1488 по 1594 год. СПб., $1851.852 \mathrm{c}$.

32. Плигузов А. Текст-кентавр о сибирских самоедах. М.; Ньютонвиль: Археографический центр, 1993. 156 с.

33. Полное собрание русских летописей, Т. 12: Летописный сборник, именуемый Патриаршею или Никоновскою летописью. СПб: Типография И.Н. Скороходова, 1901. $266 \mathrm{c}$.

34. Полное собрание русских летописей, Т. 13: Первая половина. Летописный сборник, именуемый Патриаршею или Никоновской летописью. СПб.: Типография Н.Ю. Скороходова, 1904. 303 с.

35. Полное собрание русских летописей, Т. 18: Симеоновская летопись. СПб.: Типография М.А. Александрова, 1913. 316 с.

36. Полное собрание русских летописей, Т. 25: Московский летописный свод конца XV века. М.; Л.: Издательство Академии наук СССР, 1949. 464 с.

37. Полное собрание русских летописей, Т. 26: Вологодско-Пермская летопись. М.; Л.: Издательство Академии наук СССР, 1959. 416 с.

38. Полное собрание русских летописей, Т. 33: Холмогорский летописец. Двинская летопись. Л.: Издательство «Наука», 1977. 251 с.

39. Полное собрание русских летописей, Т. 37: Устюжские и вологодские летописи XVI-XVIII вв. Л.: Наука, 1982. 235 с.

40. Полное собрание русских летописей, Т. 36: Сибирские летописи, Ч. 1: Группа Есиповской летописи. М.: Наука, 1987. 383 с.

41. Посольская книга по связям России с Ногайской Ордой. 1489-1508 гг. М.: Институт истории СССР Академии наук СССР, 1984. 99 с.

42. Преображенский А.А. Урал и Западная Сибирь в конце XVI - начале XVIII в. М.: Наука, 1972. 392 с.

43. Продолжение древней российской вивлиофики. СПб.: При Императорской Академии наук, 1801. Ч. ХІ. 315 с.

44. Пчелов Е.В. Символы Сибирского царства // Известия Уральского государственного университета, Серия 2: Гуманитарные науки. 2009. Т. 66. № 4. С. 13-22.

45. Рахимзянов Б.Р. Москва и татарский мир. Сотрудничество и противостояние в эпоху перемен, XV-XVI вв. СПб.: Евразия, 2016. 396 с.

46. Ремезов С.У. История Сибирская // Памятники литературы Древней Руси. XVII в. М.: Детская литература, 1989. Кн. 2. С. 550-582.

47. Сафаргалиев М.Г. Распад Золотой Орды // На стыке континентов и цивилизаций. М.: Инсан, 1996. С. 280-529.

48. Сборник Императорского русского исторического общества, Т. 38: Памятники дипломатических сношений Московского государства с Англией, Ч. 1: 15811604 гг. СПб., 1883. 493 с.

49. Сборник Муханова (Документы по русской истории). Второе изд., доп. СПб.: Типография Э. Праца, 1866. 799 с. 
50. Сибирские летописи. Издание Имперской Археографической комиссии. СПб.: Типография И.Н. Скороходова, 1907. 462 с.

51. Собрание государственных грамот и договоров, хранящихся в Государственной коллегии иностранных дел. М.: Типография Н.С. Всеволожского, 1819. Ч. 2. 643 с.

52. Сокровенное сказание монголов. М.: Товарищество научных изданий КМК, 2002. $156 \mathrm{c}$.

53. Солодкин Я.Г. «Взятие» Сибири в контексте территориального расширения Московского царства (глазами русских книжников конца XVI-XVII вв.) // III Емельяновские чтения: Миграционные процессы и межэтнические взаимодействия в УралоСибирском регионе. Материалы Всероссийской научно-практической конференции. Курган: Издательство Курганского государственного университета, 2008. С. 23-24.

54. Солодкин Я.Г. О принятии Борисом Годуновым титула «Сибирского царя»: хронология и мотивы // Российская история. 2015. № 3. С. 55-57.

55. Султанов Т.И. Известия османского историка XVI в. Сейфи Челеби о народах Центральной Азии // Тюркологический сборник, 2003-2004: Тюркские народы в древности и средневековье. М.: Издательская фирма «Восточная литература» Российской Академии наук, 2005. С. 254-272.

56. Трепавлов В.В. Московское и казанское «подданство» Сибирского юрта // Сулеймановские чтения: Материалы Х Всероссийской научно-практической конференции. Тюмень: СИТИ ПРЕСС, 2007. С. 101-102.

57. Трепавлов В.В. Родоначальники Аштарханидов в Дешт-и Кипчаке (заметки о предыстории бухарской династии) // Тюркологический сборник, 2007-2008: История и культура тюркских народов России и сопредельных стран. М.: Восточная литература, 2009. С. 370-395.

58. Трепавлов B.B. Сибирский юрт после Ермака: Кучум и Кучумовичи в борьбе за реванш. М.: Восточная литература, 2012. $231 \mathrm{c}$.

59. Трепавлов В.В. Шибаны: несостоявшийся этноним // Золотоордынское обозрение. 2019. Т. 7, № 2. С. 351-371. DOI: 10.22378/2313-6197.2019-7-2.351-371

60. Тычинских 3.А., Турова Н.П., Муратова С.Р. Тобол-Тура: к вопросу о сибирских городах средневековья // Интеграция археологических и этнографических исследований. Омск: Издательский дом «Наука», 2018. С. 136-140.

61. Устюжский летописный свод (Архангелогородский летописец) / Сербина К.Н. (ред.). М.; Л.: Издательство Академии наук СССР, 1950. 128 с.

62. Филюшкин А.И. Титулы русских государей. М.; СПб.: Альянс-Архео, 2006. $256 \mathrm{c}$.

63. Фоменко И.К. Образ мира на старинных портоланах. Причерноморье. Конец XIII-XVII вв. М.: Индрик, 2011. 424 с.

64. Фоменко И.К. Наследие Золотой Орды в европейской картографии XVXVIII вв. // Золотоордынское обозрение. 2013. № 1. С. 82-95.

65. Чернышов C.A. Иван Грозный - потомок Чингиз-хана или Августа: легитимизация верховной власти Московского царства в коммуникационных практиках XVXVI вв. // Золотоордынское обозрение. 2019. Т. 7, № 1. С. 159-174. DOI: 10.22378/23136197.2019-7-1.159-174

66. Шамильоглу Ю. Племенная политика и социальное устройство в Золотой Орде. Казань: Институт истории им. Ш. Марджани, 2019. 260 с.

67. Ostrowski D. Sibir, Khanate of // The Encyclopedia of Empire. John Wiley \& Sons, Ltd, 2016. Vol. IV.

Сведения об авторе: Денис Николаевич Маслюженко - кандидат исторических наук, доцент, директор Гуманитарного института, Курганский государственный университет (640020, ул. Советская, 63, корпус 4, Курган, Российская Федерация); ORCID: 0000-0001-8302-1277, ResearcherID: J-9551-2017. E-mail: denmas13@yandex.ru 
Поступила 16.03.2021 Принята к публикащии 28.05.2021

Опубликована 29.06.2021

\section{REFERENCES}

1. Abd al-Kadir ibn Mukhammad-Amin Madzhma al-ansab va-l-ashdzhar. Istoriya Kazakhstana v persidskikh istochnikakh [History of Kazakhstan in Persian Sources]. Almaty: "Dayk-Press", 2005, vol. II. 692 p. (In Russian)

2. Abul'-Gazi-Bakhadur-khan. Rodoslovnoe drevo tyurkov [The genealogical tree of the Turks]. Abul'-Gazi-Bakhadur-khan. Rodoslovnoe drevo tyurkov. Ioakinf. Istoriya pervykh chetyrekh khanov doma Chingisova. Len-Pul' S. Musul'manskie dinastii [Abu alGhazi Bahadur Khan. The Genealogical Tree of the Turks. Ioakinf. The History of the First Four Khans of the Chinggis's House. Lane-Poole S. The Mohammedan Dynasties]. Moscow; Tashkent: Baku, 1996, pp. 3-186. (In Russian)

3. Akishin M.O. D'yaki Posol'skogo prikaza i prisoyedineniye Sibiri [Scribes of the Ambassadorial Office and the accession of Siberia]. Rossiyskaya istoriya [Russian History]. 2015, no. 3, pp. 45-57. (In Russian)

4. Akty istoricheskie, sobrannye i izdannye Arkheograficheskoyu komissieyu, T. II: 1598-1613 [Historical Acts Collected and Published by the Archaeographic Commission, Vol. 2: 1598-1613]. St. Petersburg, 1841. 472 p. (In Russian)

5. Anninskiy S.A. Izvestiya vengerskikh missionerov XIII-XIV vv. o tatarakh v Vostochnoy Evrope [Notes of the Hungarian missionaries of the thirteenth and fourteenth century about Tatars in Eastern Europe]. Istoricheskiy arkhiv [Historical Archive]. Moscow; Leningrad: USSR Academy of Sciences publishing house, 1940, vol. III, pp. 71-112. (In Russian)

6. Belich I.V. K etimologii, semantike i istorii proiskhozhdeniya srednevekovogo imeni g. Tyumen' [On the etymology, semantics, and history of the origin of the medieval name of Tyumen]. Vestnik arkheologii, antropologii i etnografii [Bulletin of Archaeology, Anthropology, and Ethnography]. 2007, no. 7, pp. 143-157. (In Russian)

7. Belyakov A.V. Sibirskie tsaritsy [Siberian Queens]. Zolotoordynskoe obozrenie = Golden Horde Review. 2019, vol. 7, no. 2, pp. 372-391. DOI: 10.22378/2313-6197.2019-72.372-391 (In Russian)

8. Belyakov A.V., Maslyuzhenko D.N. Sibirsko-buharsko-nogajskie otnosheniya v svete perepiski buharskogo hana Abdallaha s sibirskim hanom Kuchumom [SiberianBukharan-Nogai relations in the light of correspondence between Abdallah, Khan of Bukhara, and Kuchum, Khan of Siberia]. Stratum plus, 2016, no. 6, pp. 229-243. (In Russian)

9. Berezin I.N. Tatarskiy letopisets. Sovremennik Boris Fedorovicha Godunova [Tatar chronicler. A contemporary of Boris Fyodorovich Godunov]. Moskovityanin [Muscovite]. 1851, iss. 24, book 2, pp. 540-554. (In Russian)

10. Bustanov A.K. Manuskripty sufiyskikh shaykhov: turkestanskaya traditsiya na beregakh Irtysha [Manuscripts of the Sufi shaykhs: Turkestan tradition on the banks of Irtysh river]. Etnografo-arkheologicheskie kompleksy: problemy kul'tury i sotsiuma [Ethnographer-archeological Complexes: Problems of Culture and Society]. Omsk: Nauka publishing house, 2009, vol. 11, pp. 195-229. (In Russian)

11. Validi Togan A. Istoriya bashkir [History of Bashkirs]. Ufa: "Kitap" publishing house, 2010. 352 p. (In Russian)

12. Vychegodsko-Vymskaya letopis' [Vychegda-Vym chronicle]. Istoriko-filologicheskiy sbornik Komi filiala AN SSSR [Historical-philological Collection of the Komi Branch of the USSR Academy of Sciences]. Syktyvkar: Komi book publishing house, 1958, vol. 4, pp. 241-270. (In Russian) 
13. Herberstein S. Zapiski o Moskovii [Notes on the Muscovite Affairs]. Moscow: Moscow University publishing house, 1998. 420 p. (In Russian)

14. Gorskiy A.A. Rus': Ot slavyanskogo rasseleniya do Moskovskogo tsarstva [Rus': From the Slavic Settlement to the Muscovite Tsardom]. Moscow: "Languagues of Slavic culture", 2004. 368 p. (In Russian)

15. Gosudarstvennyy arkhiv Rossii XVI stoletiya. Opyt rekonstruktsii [State Archive of Russia of the sixteenth century. Experience of Reconstruction]. Moscow: Institute of History of the USSR, Academy of Sciences of the USSR, 1978, part 1. 630 p. (In Russian)

16. Zolotaya Orda v istochnikakh, T. I: Arabskie i persidskie sochineniya [The Golden Horde in the Sources, Vol. 1: Arabic and Persian Writings]. Khrapacheskiy R.P. (ed.). Moscow, 2003, vol. 1. 448 p. (In Russian)

17. Zuev A.S. Sibirskoe tsarstvo [Siberian Kingdom]. Istoricheskaya entsiklopediya Sibiri, T. III: $S-Y a$ [Historical Encyclopedia of Siberia, Vol. 3: S-Ya]. Novosibirsk: Publishing house "Historical Heritage of Siberia", Institute of History of the Siberian Branch of the Russian Academy of Sciences, 2009, p. 99. (In Russian)

18. Iskhakov D.M. O titule "Sibirskiy knyaz" [About the title "Siberian Prince"]. Suleymanovskie chteniya: Materialy X Vserossiyskoy nauchno-prakticheskoy konferentsii [Suleimanov's Readings: Proceedings of the Tenth All-Russian Research and Practical Conference]. Tumen: "City-Press", 2007, pp. 46-47. (In Russian)

19. Iskhakov D.M. Ob odnom poslanii iz Povolzh'ya v Krymskoe khanstvo 1635 g. [About one message from the Volga region to the Crimean Khanate in 1635]. Krymskoe istoricheskoe obozrenie [Crimean Historical Review]. 2014, no. 2, pp. 50-62. (In Russian)

20. Kazakova N.A. "Tatarskim zemlyam imena" ["The Names of Tatar Lands"]. Kulikovskaya bitva i podyom natsional'nogo samosoznaniya [The Kulikovo Battle and the Rise of National Self-consciousness]. Likhachev D.S. (ed). Leningrad: Nauka, 1979, pp. 253-256. (In Russian)

21. Karamzin N.M. Istoriya gosudarstva Rossiyskogo [History of the Russian State]. Moscow: "Ripol-Classic", 1998, book 3, vol. VII-IX. 592 p. (In Russian)

22. Maslyuzhenko D.N., Ryabinina E.A. Pokhod 1483 g. i ego mesto v istorii russkosibirskikh otnosheniy [The campaign of 1483 and its place in the history of RussianSiberian relations]. Vestnik arkheologii, antropologii i etnografii [Bulletin of Archaeology, Anthropology, and Ethnography]. 2014, no. 1 (24), pp. 115-123. (In Russian)

23. Materialy po istorii kazakhskikh khanstv XV-XVIII vekov (izvlecheniya. iz persidskikh i tyurkskikh sochineniy) [Materials on the History of the Kazakh Khanates from the fifteenth to eighteenth century (extract from the Persian and Turkic writings)]. Suleymenov B. (ed.). Alma-Ata: Nauka, 1969. 655 p. (In Russian)

24. Materialy po istorii russkoy kartografii, Iss. I: Karty vsey Rossii i yuzhnykh ee oblastey do poloviny XVII veka [Materials on the History of Russian Cartography, Iss. 1: Maps of the Entire Russia and Its Southern Areas until the middle of seventeenth century]. Kyiv, 1899, 15 p. +32 tabl. (In Russian)

25. Miller G.F. Istoriya Sibiri [History of Siberia]. Moscow: Publishing house "Oriental literature", 2005, vol. 1. 630 p. (In Russian)

26. Mirgaleev I.M. Soobshchenie Prodolzhatelya "Chingiz-name" Utemisha-khadzhi o pozdnikh Shibanids [Information of the continuator of Ötemish Hajji's "Chingiz-nama" about the late Shibanids]. Istoriya, ekonomika i kul'tura srednevekovykh tyurko-tatarskikh gosudarstv Zapadnoy Sibiri. Materialy II Vserossiyskoy nauchnoy konferentsii [History, Economics, and Culture of Medieval Turko-Tatar States in Western Siberia. Proceedings of the Second Russian Research Conference]. Kurgan: Kurgan State University publishing house, 2014, pp. 64-66 (In Russian) 
27. Moiseyev M.V. Istoricheskiye primery $\mathrm{v}$ poslaniyakh Ivana IV $\mathrm{v}$ Krymskoye khanstvo i Nogayskuyu Ordu [Historical examples in the letters of Ivan IV to the Crimean Khanate and the Nogai Horde]. Zolotoordynskoe obozrenie=Golden Horde Review. 2018, vol. 6, no. 2, pp. 283-303. DOI: 10.22378/2313-6197.2018-6-2.283-303 (In Russian)

28. Mustakimov I. Istochniki po istorii vladeniy Shibana i Shibanidov v zolotoordynskoe vremya [Sources on the history of the possessions of Shiban and the Shibanids in the Golden Horde's time]. Istoriya i kul'tura tatar Zapadnoy Sibiri [History and Culture of the Tatars of Western Siberia]. Kazan: Marjani Institute of History of Tatarstan Academy of Sciences, 2015, pp. 168-177. (In Russian)

29. Mukhamed'yarov Sh.F. Tyumenskoe khanstvo [The Tyumen Khanate]. Ocherki istorii islamskoy tsivilizatsii [Essays on the History of Islamic Civilization]. Moscow: "Russian political encyclopedia", 2008, vol. 2, pp. 132-136. (In Russian)

30. Opisi tsarskogo arkhiva XVI veka i arkhiva Posol'skogo prikaza 1614 goda [Inventories of the Tsar Archive of the sixteenth century and the Archive of Ambassadorial Office of 1614]. Moscow: Publishing house "Oriental literature", 1960. 194 p. (In Russian)

31. Pamyatniki diplomaticheskikh snosheniy drevney Rossii s derzhavami inostrannymi, Chast' pervaya: Snosheniya s gosudarstvami evropeyskimi. Pamyatniki diplomaticheskikh snosheniy s Imperiey Rimskoy, T. I: S 1488 po 1594 god [Monuments of Diplomatic Relations of Ancient Russia with Foreign Powers, Part one: Relations with European States. Monuments of Diplomatic Relations with the Roman Empire, Vol. 1: From 1488 to 1594)]. St. Peterburg, 1851. 852 p. (In Russian)

32. Pliguzov A. Tekst-kentavr o sibirskikh samoedakh [Text-centaur about the Siberian Samoyeds]. Moscow; Newtonville: Archaeographic center, 1993. 156 p. (In Russian)

33. Polnoe sobranie russkikh letopisey, T. XII : Letopisnyy sbornik, imenuemyy Patriarshey ili Nikonovskoy letopis'yu [Complete Collection of Russian Chronicles, Vol. 12: Chronicle Collection Called Patriarchal or Nikon Chronicle]. St. Petersburg, 1901. 266 p. (In Russian)

34. Polnoe sobranie russkikh letopisey, T. XIII: Letopisny sbornik, imenuemy Patriarshey ili Nikonovskoy letopis'yu [Complete Collection of Russian Chronicles, Vol. 13: Chronicle Collection Called Patriarchal or Nikon Chronicle]. St. Peterburg: Publishing house of I.N. Skorokhodov, 1904, part 1. 303 p. (In Russian)

35. Polnoe sobranie russkikh letopisey, T. XVIII: Simeonovskaya letopis' [Complete Collection of Russian Chronicles, Vol. 18. Simeon's Chronicle]. Saint-Peterburg: Typography of M.A. Aleksandrov, 1913. 316 p. (In Russian)

36. Polnoe sobranie russkikh letopisey, T. XXV: Moskovskiy letopisnyy svod kontsa $X V$ veka [Complete Collection of Russian Chronicles, Vol. 25: Moscow Chronicle of the late fifteenth century]. Moscow; Leningrad: USSR Academy of Sciences publishing house, 1949. 464 p. (In Russian)

37. Polnoe sobranie russkikh letopisey, T. XXVI: Vologodsko-Permskaya letopis' [Complete Collection of Russian Chronicles, Vol. 26: Vologda-Perm Chronicle]. Moscow; Leningrad: USSR Academy of Sciences publishing house, 1959. 416 p. (In Russian)

38. Polnoe sobranie russkikh letopisey, T. XXXIII: Kholmogorskiy letopisets. Dvinskaya letopis' [Complete Collection of Russian Chronicles, Vol. 33: Kholmogorsky Chronicler. Dvina Chronicle]. Leningrad: Nauka, 1977. 251 p. (In Russian)

39. Polnoe sobranie russkikh letopisey, T. XXXVII: Ustyuzhskie $i$ vologodskie letopisi XVI-XVIII vv. [Complete Collection of Russian Chronicles, Vol. 37: Ustyug and Vologda Chronicles from the sixteenth to eighteenth century]. Leningrad: Nauka, 1982. 228 p. (In Russian) 
40. Polnoe sobranie russkikh letopisey, T. XXXVI: Sibirskie letopisi, Ch. 1: Gruppa Esipovskoy letopisi [Complete Collection of Russian Chronicles, Vol. 36: Siberian Chronicles, Part 1: The Group of Esipov Chronicle]. Moscow: Nauka, 1987. 383 p. (In Russian).

41. Posol'skaya kniga po svyazyam Rossii s Nogayskoy Ordoy 1489-1508 gg. [Ambassadorial Book on Russia's Relations with the Nogai Horde for 1489-1508]. Moscow: USSR Academy of Sciences publishing house, 1984. 87 p. (In Russian)

42. Preobrazhenskiy A.A. Ural i Zapadnaya Sibir' v kontse XVI-nachale XVIII v. [The Urals and Western Siberia from the late sixteenth to early eighteenth century]. Moscow: Nauka, 1972. 392 p. (In Russian)

43. Prodolzhenie drevnej rossijskoj vivliofiki [Continuation of the Ancient Russian Library]. St. Petersburg, 1801, vol. 11.315 p. (In Russian)

44. Pchelov E.V. Simvoly Sibirskogo tsarstva [Symbols of the Siberian Tsardom]. Izvestiya Ural'skogo gosudarstvennogo universiteta, Seriya 2: Gumanitarnye nauki [Proceedings of the Ural State University, Series 2: Humanities]. 2009, vol. 66, no. 4, pp. 1322. (In Russian)

45. Rakhimzyanov B.R. Moskva i tatarskiy mir. Sotrudnichestvo i protivostoyanie v epokhu peremen, $X V-X V I v v$. [Moscow and Tatar World. Cooperation and Conflict during the Era of Changes, the fifteenth and sixteenth centuries]. St. Petersburg: "Eurasia", 2016. 396 p. (In Russian).

46. Remezov S.U. Istoriya Sibirskaya [History of Siberia]. Pamyatniki literatury Drevney Rusi. XVII v. [Monuments of Literature of Ancient Rus'. The seventeenth century]. Moscow: "Children's literature”, 1989, vol. 2, pp. 550-582. (In Russian)

47. Safargaliev M.G. Raspad Zolotoy Ordy [Dissolution of the Golden Horde]. $\mathrm{Na}$ styke kontinentov $i$ tsivilizatsiy [At the Crossroads of Continents and Civilizations]. Moscow: "Insan", 1996, pp. 280-529. (In Russian).

48. Sbornik Imperatorskogo Russkogo Istoricheskogo Obshchestva, T. XXXVIII: Pamyatniki diplomaticheskikh snosheniy Moskovskogo gosudarstva s Angliyey, Ch. 1: 1581-1604 gg. [Collection of the Imperial Russian Historical Society, Vol. 38: Monuments of Diplomatic Relations of the Moscow State with England, Part 1: 1581-1604]. St. Petersburg, 1883. 493 p. (In Russian)

49. Sbornik Mukhanova (Dokumenty po russkoy istorii) [Mukhanov's Collection (Documents on Russian history)]. St. Petersburg: Publising house of E. Prats, 1866. 799 p. (In Russian)

50. Sibirskie letopisi. Izdanie Imperskoy Arkheograficheskoy komissii [Siberian Chronicles. Publication of the Imperial Archaeographic Commission]. St. Peterburg: Publishing house of I.N. Skorokhodov, 1907. 462 p. (In Russian)

51. Sobranie gosudarstvennyh gramot i dogovorov, hranjashhihsja v Gosudarstvennoj kollegii inostrannyh del [Collection of State Charters and Treaties Stored in the State Collegium of Foreign Affairs]. Moscow, 1819, part 2. 643 p. (In Russian).

52. Sokrovennoe skazanie mongolov [The Secret History of the Mongols]. Moscow: KMK scientific publishing partnership, 2002, 156 p. (In Russian)

53. Solodkin Ya.G. "Vzyatie" Sibiri v kontekste territorial'nogo rasshireniya Moskovskogo tsarstva (glazami russkikh knizhnikov kontsa XVI-XVII vv.) ["Capture" of Siberia in the context of territorial expansion of the Moscow Tsardom (through the eyes of Russian scribes of the late sixteenth and seventeenth centuries.)]. III Emel'yanovskie chteniya: Migratsionnye protsessy i mezhetnicheskie vzaimodeystviya v Uralo-Sibirskom regione. Materialy Vserossiyskoy nauchno-prakticheskoy konferentsii [The Third Yemelyanov Readings: Migration Processes and Interethnic Interactions in the UralSiberian Region. Proceedings of the All-Russian Research and Practical Conference]. Kurgan: Kurgan State University publishing house, 2008, pp. 23-24. (In Russian) 
54. Solodkin Ya.G. O prinyatii Borisom Godunovym titula "Sibirskogo tsarya": khronologiya i motivy [On Boris Godunov's acceptance of the title of "Siberian Tsar": chronology and motives]. Rossiyskaya istoriya [Russian History]. 2015, no. 3, pp. 55-57. (In Russian).

55. Sultanov T.I. Izvestiya osmanskogo istorika XVI v. Seyfi Chelebi o narodakh Tsentral'noy Azii [Information of the sixteenth-century Ottoman historian, Seyfi Celebi, on peoples of Central Asia]. Tyurkologicheskiy sbornik, 2003-2004: Tyurkskie narody v drevnosti i srednevekov'e [Turkological Collection, 2003-2004: Turkic Peoples in the Ancient and Medieval Periods]. Moscow: Publishing house "Oriental literature", 2005, pp. 254-272. (In Russian)

56. Trepavlov V.V. Moskovskoe i kazanskoe "poddanstvo" Sibirskogo yurta [Muscovite and Kazan "allegiance" of the Siberian Yurt]. X Suleymanovskie chteniya. Sbornik materialov vserossiyskoy nauchno-prakticheskoy konferentsii [The Tenth Suleymanov Readings. Proceedings of the All-Russian Research and Practical Conference]. Tyumen: "City Press", 2007, pp. 101-102. (In Russian)

57. Trepavlov V.V. Rodonachal'niki Ashtarhanidov v Desht-i Kipchake (zametki o predystorii buharskoj dinastii) [The ancestor of the Ashtarkhanids in the Desht-i Kipchak (notes on the prehistory of the Bukharian dynasty)]. Tjurkologicheskij sbornik, 2007-2008: Istorija i kul'tura tjurkskih narodov Rossii i sopredel'nyh stran [Turkological Collection, 2007-2008: The History and Culture of the Turkic Peoples of Russia and Adjacent Countries]. Moscow: Publishing house "Oriental literature", 2009, pp. 370-395. (In Russian)

58. Trepavlov V.V. Sibirskiy yurt posle Ermaka: Kuchum i Kuchumovich v bor'be za revansh [Siberian Yurt after Ermak: Kuchum and the Kuchumovichi in the Struggle for Revenge]. Moscow: Publishing house "Oriental literature", 2012, 231 p. (in Russian).

59. Trepavlov V.V. Shibany: nesostoyavshiysya etnonim [The Shibans: A failed ethnonym]. Zolotoordynskoe obozrenie=Golden Horde Review. 2019, vol. 7, no. 2, pp. 351-371. DOI: 10.22378/2313-6197.2019-7-2.351-371 (In Russian)

60. Tychinskikh Z.A., Turova N.P., Muratova S.R. Tobol-Tura: k voprosu o sibirskikh gorodakh srednevekov'ya [Tobol-Tura: On the Siberian cities of the Middle Ages]. Integratsiya arkheologicheskikh i etnograficheskikh issledovaniy [Integration of Archaeological and Ethnographic Research]. Omsk: Publishing house Nauka, 2018, pp. 136-140. (In Russian).

61. Ustyuzhskiy letopisnyy svod (Arkhangelogorodskiy letopisets) [Ustyug Chronicle Collection (Archangel City's Chronicler)]. Serbina K.N. (ed.). Moscow; Leningrad: USSR Academy of Sciences publishing house, 1950. 128 p. (In Russian).

62. Filyushkin A.I. Tituly russkikh gosudarey [The Titles of Russian Rulers]. Moscow; St. Peterburg: "Alliance-Archeo", 2006. 256 p. (In Russian)

63. Fomenko I.K. Obraz mira na starinnykh portolanakh. Prichernomor'e. Konets XIII-XVII vv. [The Image of World in the Ancient Portolani. The Black Sea Region. From the end of thirteenth to seventeenth centuries]. Moscow: "Indrik", 2011. 424 p. (In Russian)

64. Fomenko I.K. Nasledie Zolotoy Ordy v evropeyskoy kartografii XV-XVIII vv. [The legacy of the Golden Horde in the European cartography from the fifteenth to eighteenth centuries]. Zolotoordynskoe obozrenie=Golden Horde Review. 2013, no. 1, pp. 82-95. (In Russian)

65. Chernyshov S.A. Ivan Groznyy - potomok Chingiz-khana ili Avgusta: legitimizatsiya verkhovnoy vlasti Moskovskogo tsarstva v kommunikatsionnykh praktikakh XVXVI vv. [Ivan the Terrible - Chinggis Khan's or Augustus's descendant: Legitimization of the supreme authority of the Moscow Tsardom in communication practices of the $15^{\text {th }}-16^{\text {th }}$ centuries]. Zolotoordynskoe obozrenie=Golden Horde Review. 2019, vol. 7, no. 1, pp. 159174. DOI: 10.22378/2313-6197.2019-7-1.159-174 (In Russian) 
66. Schamiloglu Y. Plemennaya politika i sotsial'noe ustroystvo v Zolotoy Orde [Tribal Politics and Social Structure in the Golden Horde]. Kazan: Marjani Institute of History of Tatarstan Academy of Sciences, 2019. 260 p. (in Russian).

67. Ostrowski D. Sibir, Khanate of. The Encyclopedia of Empire. John Wiley \& Sons, Ltd, 2016, vol. 4.

About the author: Denis N. Maslyuzhenko - Cand. Sci. (History), Associate Professor, Director of the Institute of Humanities, Kurgan State University (63, building 4, Sovetskaya Str., Kurgan 640020, Russian Federation); ORCID: 0000-0001-8302-1277, ResearcherID: J-9551-2017. E-mail: denmas13@yandex.ru

Received March 16, 2021 Accepted for publication May 28, 2021 Published June 29, 2021 


\title{
ЖИЗНЬ И СМЕРТЬ МАНГЫТСКОГО КАРАЧИ-БЕКА ДИВЕЯ
}

\author{
А.Г. Бахтин \\ Марийский государственный университет \\ Йошкар-Ола, Российская Федерация \\ abachtin@mail.ru
}

Цель исследования: проследить судьбу аристократов из крымских мангытов рода Мансур XVI века - братьев Баки, Ходжи-Ахмеда, Ак-Биби и Дивея, выявить их роль в политических событиях Восточной Европы, установить обстоятельства пленения, нахождения в плену и смерти Дивея - самого известного из братьев.

Материалы исследования: анализ сообщений летописей, разрядных книг, сочинений, дипломатической документации, фольклора, материалов исторических исследований.

Результаты и научная новизна исследования: прослежены судьбы братьев из знатного мангытского рода Мансур - Баки, Ходжи-Ахмеда, Ак-Биби и Дивея, трое из которых стали карачи-беками в Крыму. Они участвовали в политической жизни Крыма, Ногайской Орды, Астрахани, Азова, Русского государства, Венгрии и Ирана. Князь Дивей являлся типичным степным багатуром, искателем славы и богатства, активным противником Русского государства. Много раз он предпринимал набеги на русские земли. Проявил незаурядные полководческие способности, был агрессивным, смелым, решительным и жестоким. В 1572 году в ходе Молодинской битвы командовал крымскими войсками и попал в плен к русским. Пленение военачальника стало одной из причин поражения крымцев. Это в очередной раз спасло Русское государство от внешней зависимости. Хан Девлет-Гирей прилагал немалые усилия по освобождению карачи-бека ещё в ходе битвы, но потерпел неудачу. Попытки выкупить или разменять пленника тоже оказались тщетными. Иван Грозный осознавал исходящую от него угрозу и не хотел освобождать знатного пленника. В 1576 году в Москве заявили о смерти князя Дивея. В историографии ставится под сомнение его смерть в 1575 году. Существует мнение, что Дивей принял крещение и поступил на службу к Ивану Грозному под именем Даниила-мурзы. Автор полагает, что историки, сопоставив Дивея с Даниилом-мурзой, подошли к вопросу поверхностно, не рассматривали всех источников, вообще не разбирали его специально, поэтому пришли к неверным выводам, которые стали повторяться в последующих публикациях. Князь Дивей и Даниил-мурза - разные люди. Дивей не согласился принять православие и был казнён. Выключение известного крымского военачальника из политической жизни способствовало снижению агрессивности Крымского ханства в отношении России и дестабилизации политической ситуации в Крыму.

Ключевые слова: мангыты, карачи-бек, Баки, Ходжа-Ахмед, Ак-Биби, Дивей, Даниил-мурза, набеги, Молодинская битва, плен, казнь

Для цитирования: Бахтин А.Г. Жизнь и смерть мангытского карачи-бека Дивея // Золотоордынское обозрение. 2021. Т. 9, № 2. С. 395-422. DOI: 10.22378/23136197.2021-9-2.395-422 


\title{
THE LIFE AND DEATH OF THE MANGHIT QARACHI-BEK, DIVEI
}

\author{
A.G. Bakhtin \\ Mari State University \\ Yoshkar-Ola, Russian Federation \\ abachtin@mail.ru
}

\begin{abstract}
Research objectives: To trace the fate of the sixteenth-century aristocrats from the Mansur kin of the Crimean Manghits, namely the brothers Baki, Khoja-Akhmed, Ak-Bibi, and Divei. To identify their role in political events in Eastern Europe and to establish the circumstances of the capture, stay in captivity, and the death of Divei - the most famous of these brothers.

Research materials: Chronicles, Razriad books, diplomatic documents, folklore, and secondary materials of historical research.

Results and novelty of the research: The author traced the fate of the brothers from the noble Maghit kin of Mansur, namely Baki, Khoja-Akhmed, Ak-Bibi and Divei, three of whom became Qarachi-beks in Crimea. They participated in the political life of Crimea, the Nogai Horde, Astrakhan, Azov, the Russian state, Hungary, and Iran. Prince Divei was a typical steppe bagatur, a seeker of fame and fortune, as well as an active enemy of the Russian State. He repeatedly raided the Russian lands and displayed outstanding abilities as a commander. He was aggressive, brave, determined, and cruel. In 1572, he commanded the Crimean troops in the Battle of Molodino and was captured by the Russians. The capture of their commander was one of the reasons for the defeat of the Crimeans. This event once more saved the Russian state from external dependence. Devlet-Girei Khan made considerable efforts to free the Qarachi-bek during the battle, but these were in vain. Attempts to redeem or exchange the prisoner were likewise in vain. Ivan the Terrible was aware of the threat posed by this figure and did not want to free his noble prisoner. In 1576 , the death of Prince Divei was announced in Moscow. Historiography calls into question his death in 1575. There is an opinion that Divei was baptized and entered the service of Ivan the Terrible under the name of Daniil-murza. In this article, the author contends that those historians who compared Divei with Daniil-murza approached the issue superficially, not considering all the sources, and therefore came to the wrong conclusions. These began to be repeated in subsequent publications. Prince Divei and Daniil-murza were different persons. Divei did not agree to accept Orthodoxy and was executed. The elimination of the famous military leader from its political life contributed to a decrease in the aggression of the Crimean Khanate towards Russia as well as the destabilization of the political situation in Crimea.
\end{abstract}

Keywords: Manghits, Qarachi-bek, Baki, Khodja-Akhmed, Ak-Bibi, Divei, Daniilmurza, raids, battle of Molodino, captivity, execution

For citation: Bakhtin A.G. The Life and Death of the Manghit Qarachi-bek, Divei. Zolotoordynskoe obozrenie=Golden Horde Review. 2021, vol. 9, no. 2, pp. 395-422. DOI: $10.22378 / 2313-6197.2021-9-2.395-422$

Одной из ярких личностей в XVI в. на Востоке Европы являлся крымский мангытский карачи-бек Дивей (Девей, Деве), принадлежащий к клану Мансур [24, с. 210-211]. Он обладал несомненным дарованием военачальника, был харизматичным и авторитетным лидером, подобным багатурам из тюркского эпоса. Андрей Михайлович Курбский (1528-1583) называл Дивея славным ханским гетманом, «кровопийцей христианским» [34, с. 287]. Лето- 
писец считал его лучшим ханским воеводой [37, с. 229]. В соответствии с местнической системой Иван Грозный (1533-1584) сопоставлял князя Дивея со своими большими воеводами князем Семеном Ивановичем ПунковымМикулинским (Телятевским) (ум. 1559) и дядей князем Михаилом Васильевичем Глинским (ум. 1559) [53, с. 641-642]. Славным богатырём и великим кровопийцем христианским считает Дивея один из первых русских историков А.И. Лызлов (1655-1697) [35, с. 148]. Н.М. Карамзин (1766-1826) характеризует его как знатнейшего храбреца неверных, называет бичом и губителем христиан [30, с. 83]. Современный историк В.В. Трепавлов считает его «весьма воинственным и агрессивным» [71, с. 305]. Амбициозным и надменным определяет Дивея специалист по истории Крымского ханства А.В. Виноградов [33, с. 431$]$.

Специальной биографической работы его личность не удостоилась, однако имя часто встречается в исторической литературе, посвящённой русскокрымским отношениям третьей четверти XVI века. Наиболее часто Дивей упоминается при описании Молодинской битвы 28 июля - 2 августа 1572 г., где он возглавлял ханские войска и попал в плен $[3 ; 5$, с. 48-79; 11 , с. 275; 13 , с. $202-253 ; 14$, с. $155-157 ; 21 ; 31$, с. $416-417 ; 41$, с. $745-746 ; 44$, с. $430 ; 47 ; 67$, c. $519 ; 68$, с. 173-174]. Наиболее полная информация о Дивее мурзе собрана В.В. Трепавловым [71] и в примечаниях А.В. Виноградовым [9, с. 125-127; 33, с. 431-432]. Упоминается он в работах некоторых иностранных авторов [76, p. 445-466]. Самым тёмным местом в биографии этого человека является нахождение его в плену и обстоятельства смерти. Попробуем разобраться.

Прапрадедом Дивея мурзы был знаменитый временщик поздней Золотой Орды князь Едигей (ок. 1357-1419). От его сына Мансура родился Тимур, а у того уже - отец Дивея Хасан. Дивей б. Хасан имел старших братьев Баки, Ходжи-Ахмеда (Ходжатая) и Ак-Биби. Они приходились племянниками замечательной женщине - казанской и крымской царице Нур-Султан (ок. 1450 - после 1523).

Братья, особенно Баки и Дивей, являлись типичными степными батырами, стремившимися к поиску воинской славы и богатой добычи. Они совершали набеги на осёдлое и кочевое население, участвовали в междоусобицах, поступали наёмниками к мусульманским правителям [23, с. 424-425].

Изначально братья принадлежали к мангытскому улусу, находившемуся в южной части западного Дешт-и Кипчака, примыкавшей с севера к Крыму. Улус был основан их дедом Тимуром, откочевавшим со своим родовым объединением (элем) на земли между Перекопом и Днепром ещё в 1470-х гг. После гибели в 1502 г. Большой Орды мангыты во главе с сыном Тимура князем Таваккулом вошли в подчинение крымского хана. Уже в 1530-е гг. глава рода стал карачи-беком, сравнявшись с Ширинами, Барынами, Аргынами и Кипчаками. После Таваккула эль возглавил его брат Хасан, отец Дивея $[12$, с. $55-56 ; 54$, с. 326$]$.

Первым из братьев на историческую арену вышел Баки. Ранее упоминание о нём относится к 1524 году. Тогда он вместе с другими представителями крымской знати шертовал перед послом Василия III Астафьем Андреевым [36, с. 413]. Когда разгорелась борьба за власть между племянником царевичем Ислам-Гиреем и дядей ханом Саадет-Гиреем (1524-1532), Ислам привлёк 
Баки на свою сторону и поставил мангытским беком. После примирения, хан назначил Ислама калгою и признал за Баки княжеский статус [71, с. 184].

\section{Схема 1. Мангытские беки Крымского ханства}

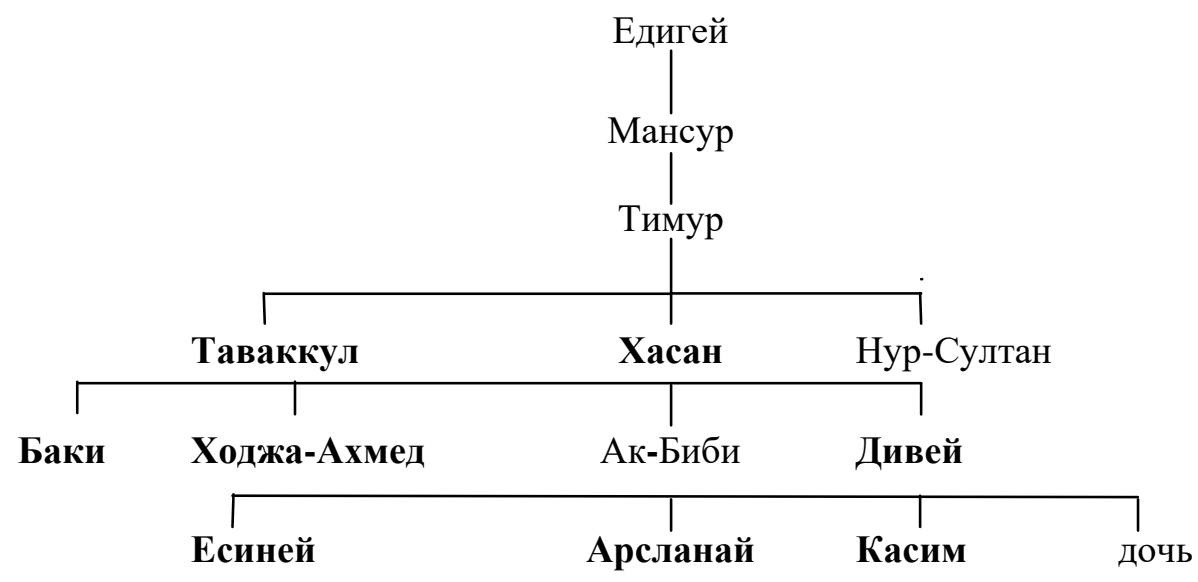

Баки совершал нападения на русские земли. В Посольском приказе ногайским послам говорили, что осенью 1532 года «приходил Бакий князь на государя нашего украины, на Мещерские места, и под Городом ${ }^{1}$ стояли, посады жгли и сёла воевали, людей до смерти били, и иных головами с собою посвели, и животы их пограбили» [56, с. 101]. Это произошло в то время, когда ногайцы выстраивали мирные торговые отношения с Россией. Ногайский князь Саид-Ахмед разгневался. Он сообщал в Москву: «Бакы шол и землю твою воевали. И яз его прогонил в Крым...» [56, с. 94]

Турецкий историк XVI в., личный врач крымского хана Сахиб-Гирея (1532-1550) 2 Реммал ходжа (ум. ок. 1569) 3 в своём сочинении «История Сахиб-Гирей хана», написанном в 1551-1553 гг. уделил внимание как Дивею, так и его братьям. Он пишет, что вскоре после прихода к власти в Крыму Сахиб-Гирея, к хану перебежал от царевича Ислам-Гирея Баки бей. Хан хорошо встретил князя и тайно поручил вернуться к Исламу и убить его. Они инсценировали ссору, после чего Баки бей покинул Крым, но не смог выполнит поручения, т. к. Ислам не доверял перебежчику и не подпустил его к себе. Баки ушёл в Ногайскую Орду $[77, \text { s. 159-161] }]^{4}$. Судя по сообщению ногайской посольской книги, это произошло в начале 1535 года [56, с. 128]. В декабре того же года с ногайским посольством Баки прислал письмо великому князю, в котором предупреждал о намерении крымцев произвести нападение, обещал защищать русские границы и просил подарки [56, с. 134-135].

\footnotetext{
${ }^{1}$ М.В. Моисеев предполагает г. Касимов. М.М. Акчурин допускает, что это Старый Кадом или Старый Темников. [2, с. 166; 39, с. 414-422; 40. с. 86].

${ }^{2}$ Обычно окончание правления Сахиб-Гирея относят к 1551 г., но есть основания считать, что это произошло в ноябре-декабре 1550 года. См. [43, с. 51, 57, прим. 42].

${ }^{3}$ Реммал ходжа (Господин предсказатель) - прозвище Бадр ад-Дина Мухаммеда б. Мухаммед Кайсуни-заде Нидаи-эфенди.

${ }^{4}$ Современный перевод на русский язык см. [1].
} 
После этого сведения о Баки бее из русских источников исчезают до лета 1537 года. Больше года, в соответствии с сообщением Реммал ходжи, Баки бей находился в Персии и Хорасане по приглашению кызылбашских эмиров. Там «он совершил много актов героизма со своим младшим братом Дивей мурзой, который был в этих странах. Их уважали и их имена стали известными» [77, s. 161].

Во главе рода Мансур в Крыму в 1536 г. хан поставил карачи-беком Ходжу-Ахмеда [12, с. 58]. В Крыму находился и другой брат мурза Ак-Биби. В 1537 году хан прислал в Москву списки знати, которой нужно присылать подарки, братья упоминаются по мангытскому списку 5 .

Вернувшись вместе с Дивеем в родные причерноморско-прикаспийские степи, осмелевший от военных успехов Баки бей неожиданно в начале лета 1537 г. вместе с братом напал на своего бывшего сюзерена царевича Ислама, убил его «и улус взял, и жёны его поимал...» Тогда же был захвачен находящийся у царевича беглый князь Семён Фёдорович Бельский [49, с. 119, 121 , $124 ; 51$, с. 30-31] $]^{6}$ Устранив претендента на ханство, Баки рассчитывал стать карачи-беком крымских мангытов, но хан не утвердил его в этом статусе. Сахиб-Гирей опасался возросшего авторитета Баки и его тесных связей с мурзами Ногайской Орды [12, с. 58], да и Ходжа-Ахмед его устраивал. Баки не без оснований опасался, что хан может убить его и не пошёл в Крым.

Некоторое время братья находились на службе у астраханского хана и не шли в Ногайскую Орду, опасаясь мести шуринов Ислама ${ }^{7}-$ видимо, братьев его ногайских жён. Из сочинения Реммал ходжи известно, что Баки и Дивей пребывали потом в Азове и возглавляли азовских казаков $[77, \text { s. } 193]^{8}$, т. е. оторвавшихся от своих родов тюркских воинов, искателей добычи и приключений. Таких много скиталось по степям. Впоследствии они участвовали в формировании донского казачества.

В октябре братья прислали с ногайским посольством письма в Москву с требованием подарков. Если Баки писал сдержанно, то младший брат не церемонился в желании получить побольше подарков. В посольской книге он выведен под другим именем, для переводчика это был новый человек, но нет сомнения, что это Дивей: «А се грамота Девлет Киреева Бакиева меншово брата: “Бакыев меншей брат Девлет Кирей Ивану князю поклон. Мы з братом своим старейшим до твоей земли не дотыкаемся, и тобе было пригоже нас почтити. Мы не пойдем твоей земли воевати, а из сее земли нихто не ходит опричь нас воевати. И ты, как наперед того отца нашего Темиря князя чтили, так и нас чтите, ведь мы того ж от царя дети"» [56, с. 204-206]. Смысл такой - мы на твои земли не нападаем, а могли бы, так как самые воинственные

\footnotetext{
5 Российский государственный архив древних актов (далее - РГАДА). Ф. 123. Сношения России с Крымом. Кн. № 8. Л. 542 об. - 543.

${ }^{6}$ РГАДА. Ф. 123. Сношения России с Крымом. Кн. № 8. Л. 360, 403.

${ }^{7}$ РГАДА. Ф. 123. Сношения России с Крымом. Кн. № 8. Л. 413-413 об.

${ }^{8}$ Есть мнение, что Баки находился в Иране в 1537-1539 гг. См. [10, с. 58; 63 , с. 227]. Однако братья, судя по источникам, оставались в это время в Северном Причерноморье. По Реммал ходже, Баки уехал в Иран к пребывающему уже там Дивею, в то время как в указанные годы они находились вместе. Также сомнительно, что они увезли в Иран своего знатного пленника С.Ф. Бельского, который вскоре был передан ими в Крым.
} 
среди ногайцев, поэтому присылай нам такие же подарки как деду нашему Тимуру.

В июне 1538 года князь Баки присылал в Москву с ногайским посольством своего посла с грамотой, в которой писал об убийстве царевича Ислама и пленении находившегося у того Семёна Бельского. Князь предлагал дружбу, просил разрешить его людям торговать и предлагал за выкуп передать знатного перебежчика в Москву. Там заинтересовались предложением и предпринимали попытки выкупить пленника, но, в конце концов, он оказался в Крыму $[48$, с. $447 ; 49$, с. $124 ; 51$, с. $32-33$; 22, с. $63-108 ; 25$, с. 131-158; 32, c. $98-115]$.

Наметившееся сближение с Русским государством направило активность братьев против Крыма. В декабре 1539 года они совершили нападение возле Днепра на возвращавшегося из похода на каширские места и Растовьскую волость с полоном царевича Эмин-Гирея $[49, \text { с. } 130 ; 51, \text { с. } 36]^{9}$. Смогли отбить у татар значительную часть добычи, забрали продовольствие. В условиях холодной зимы это привело к гибели от трёх до четырёх тысяч крымских воинов. Но уйти безнаказанно братьям не удалось. Подошедшие из Крыма войска настигли их и разбили. Примечательно, что среди этих войск во главе мангытов находился их брат Ходжа-Ахмед. Баки с двумя сотнями воинов сумел уйти, прикрывавший же отход Дивей попал в плен и более года находился в заключении. Одновременно арестовали Ак-Биби мурзу из-за подозрений в сочувствии к братьям. Они были скованы цепями и имели кандалы на ногах, но в остальном содержание оказалось достаточно мягким. Их держали во дворце хана и кормили с его стола. Однажды хан навестил пленников. Сахиб-Гирей заверил братьев, что не сердится на них и держит их в заключении только из-за злодеяний их брата Баки бея. Затем приказал снять цепи и кандалы и пообещал выдать замуж за Ак-Биби свою дочь. Братьев отправили в баню (хаммам) и переодели в новую хорошую одежду. Хан пожаловал их халатами. После этого они находились во дворце уже на положении гостей. Столь мягкое отношение с пленниками диктовалось желанием с их помощью заманить Баки бея в Крым и прекратить таким образом нападения. Дивей ездил в Азов и встречался со старшим братом, но так и не смог его склонить к переезду в Крым. Сумел это сделать только Ак-Биби, которому очень хотелось стать ханским зятем [77, s. 190-193].

Баки бея хорошо приняли в Крыму, хан поставил его во главе крымских мангытов. Некоторые приближённые предостерегали хана от доверия мангытскому бею. Хан решил подождать и действовать только после того, как проявятся «злые намерения» мангытского князя. Оппозиция в свою очередь предупреждала Баки: «Не будь в неведении! Они - падишахи, проявив почтительное отношение, убивают любимых людей. Смотри, не теряй шанса!». Баки находился в сильном сомнении относительно своего будущего и даже помышлял бежать из Крыма. Он также решил подождать и посмотреть, «откуда подует ветер». В то же время он допустил, что может убить хана в ближайшем походе [77, s. 197-198; 1, Ч. 2, с. 220-221].

Во время похода на Россию в 1541 г. Сахиб-Гирей заподозрил Баки бея в намерении совершить покушение во время переправы хана через Оку. Это

\footnotetext{
${ }^{9}$ РГАДА. Ф. 123. Сношения России с Крымом. Кн. № 8. Л. 665 об. - 666.
} 
привело к задержке и, в конечном счёте, определило неуспех похода, т.к. русские, пока хан с беем выясняли отношения, успели подтянуть резервы и заняли жёсткую оборону по берегу реки. Пришлось отступать. Взаимное недоверие усилилось. Опасаясь за свою жизнь, Баки бей не пошёл в Крым, но хан зимой 1542/3 г. сумел заманить его в ловушку и, заковав в цепи, привёз в Бахчисарай. У братьев было договорено, что Ак-Биби мурза придёт на помощь в случае необходимости, но тот проявил малодушье, не решился напасть на хана и тоже оказался под арестом. Хан припомнил Баки бею, как из-за него погибли от холода тысячи крымских воинов, и подверг его медленной мучительной казни, поместив раздетым, в условиях зимы, в бассейн с холодной водой. Ак-Биби мурзу просто задушили [77, s. 193-209; 69, с. 306; 17, с. 35].

Расправа над братьями не отразилась на судьбе двух других - ХоджиАхмеда и Дивея. В 1542 году Дивей мурза по распоряжению хана возглавил перебегавших в Крым ногайцев, которых селили в северной части ханства. Главой рода Мансур, видимо, стал Ходжа-Ахмед как старший из уцелевших братьев. Из сочинения Реммал ходжи известно, что он оставался в Крыму и в 1550 г., во время прихода к власти Девлет-Гирея (1550-1577), участвовал в расправе над малолетними сыновьями и внуками Сахиб-Гирей хана - Хаджой, Селяметом, Газанфером, Джафером и Кутлугом, которым он приходился дядей. Это означает, что Ходжа-Ахмед был женат на сестре или дочери хана. Реммал ходжа пишет, что в Крыму «нет никого, кто не проклинает его». Позднее Девлет-Гирей расправился с непосредственными исполнителями убийства своего дяди Сахиб-Гирея, его сыновей и внуков [77, с. 266, 274]. Очевидно, пострадал и Ходжа-Ахмед, сведения о нём пропадают из источников. Косвенно последний раз он упоминается в 1559 г., когда хан послал «Девай-мурзу з братиею» в набег на русские земли [51, с. 276]. В июле того же года, совершавший поход на Крым, Данила Адашев «писал ко государю, что царь крымской нагайских мурз в Крыму побил у собя многих...» [51, с. 280, 283]. Возможно, устранение Ходжи-Ахмеда произошло в начале 1563 г., т. к. в мае хан сделал Дивея карачи-беком [33, с. 431; 71, с. 360]. Так Дивей стал князем, хотя в русских источниках наряду с княжеским продолжали привычно указывать его мурзинское достоинство.

Какую позицию занял Дивей мурза во время свержения Сахиб-Гирея, не известно. Вскорости после переворота мы находим его в Ногайской Орде. Вероятно, он опасался нового турецкого ставленника. В начале 1551 года он в качестве посла ногайского князя Юсуфа приезжал в Москву и вёл переговоры о дружбе «и на недруга заодин стояти» [57, с. 55]. В апреле он вместе с послом Ивана IV Петром Тургеневым был отпущен из Москвы [57, с. 48]. В октябре того же года Дивей присылал в Москву своего посла Сююндюка [57, c. 76]. После этого упоминания о нём исчезают из ногайских посольских книг. Мурза вновь перебрался в Крым. Ногайские мигранты продолжали прибывать и существенно усиливать военную мощь Крымского ханства. Они обеспечивали охрану и оборону полуострова с севера, в первую очередь против Большой Ногайской Орды и казаков ${ }^{10}$. На реке Миус Дивей основал столицу своего улуса Болы-Сарай [11, с. 62]. Влияние как мангытского рода Мансур, так и возглавлявшего его карачи-бека в ханстве заметно возросло.

${ }^{10}$ РГАДА. Ф. 123. Сношения России с Крымом. Кн. № 11. Л. 208 об. 
Дивей имел сыновей Есинея (ум. 1584), Арсланая (ум. 1595), Касима и дочь. Хан Девлет-Гирей высоко ценил Дивея и в 1563 г. даже породнился с ним, выдав за его сына Арсланая свою дочь [71, с. 124, 225, 227, 228, 305, 306, 360-362]. В 1571 году царевич Адыл-Гирей взял себе в жёны дочь Дивея [54, c. 337].

В отношении России Дивей проводил враждебную политику. В 1546 году он явился к русским послам и грубо вымогал себе подарки, более тех, которые ему прислали. Не добившись своего, он задержал 55 русских, приехавших в Крым искать и выкупать попавших в плен родственников. За их освобождение он требовал платы. Это так возмутило русское правительство, что в марте 1547 г. великий князь приказал арестовать находившихся в Москве крымских послов ${ }^{11}$.

Он участвовал в походах против России, проявлял военные и организаторские способности. В январе 1559 года царевичи нападали на Тулу и Рязань. Дивей с Ширинскими мурзами должен был атаковать Каширу. Однако, узнав о присутствии на границе значительных воинских сил, татары спешно отступили, загоняя насмерть лошадей и верблюдов [49, с. 314; 51, с. 276-277].

Не удовлетворившись результатами неудачного похода, в ноябре того же года Дивей мурза с Ширинскими мурзами во главе 3000 воинов напал на Растовьскую волость. На этот раз предприятие оказалось более удачным. Татары «пришли безвестно». Воевода Фёдор Иванович Татев не успел собрать достаточно воинов, поэтому не смог организовать преследование уходивших с полоном крымцев [49, с. 321].

В 1560 году Дивей нападал на северские земли и осаждал Рыльск [59, c. $35 ; 63$, с. 188$]$. В августе того же года его трёхтысячный отряд через Потежский лес прорвался к Туле и Зарайску и захватил большой полон. Отступать пришлось медленно, и у р. Дон на этот раз его настигла погоня. Дивей приказал перебить пленных и только так сумел оторваться от преследователей $[49$, с. $328 ; 62$, с. $96 ; 63$, с. $11-12]$.

Летом 1561 года ногайский князь Исмаил сообщал Ивану Грозному, что Дивей мурза и предводитель Малой Ногайской Орды Казый-мурза сговариваются «на то, что ему тебя и меня воевати» [57, с. 336].

В июле 1562 года Дивей участвовал в нападении хана на Мценск, Одоев, Новосиль, Болхов, Чернь и Белёв. Хан надеялся, что царь Иван ушёл в поход на Литву, но узнав, что против него направлены основные силы русского войска, повернул назад. Дивей мурза, Мустафа ага и другие князья и мурзы уходить без добычи не захотели и при отступлении напали на Болхов и белёвские места. Загонные татарские отряды начали грабёж и захват пленных, но в это время подошёл воевода Василий Андреевич Бутурлин и не дал производить разбой, многие крымцы были побиты, а пленные освобождены [49, с. $341-342 ; 51$, с. 299].

Весной 1563 года Дивей вместе с царевичами приходил на дедиловские, пронские и рязанские места, приблизился к Михайлову ${ }^{12}$.

Летом 1564 года в Бахчисарае решался вопрос о том, с кем воевать, а с кем заключать мир: с Речью Посполитой или с Россией. Это создавало усло-

\footnotetext{
11 РГАДА. Ф. 123. Сношения России с Крымом. Кн. № 9. Л. 51 об.

12 РГАДА. Ф. 123. Сношения России с Крымом. Кн. № 10. Л. 111-112.
} 
вия для политического торга. Для раздумий, против кого воевать, у Дивея имелись основания. Его улусы располагались за пределами полуострова между Перекопом и Днепром и подвергались нападениям запорожских казаков. На заседании дивана хан говорил: «казаки пришед Днепром у Дивия мурзы у Перекопи улусы поимали» ${ }^{13} .20$ июля Дивей приехал к послу Афанасию Нагому. Его призвали послужить царю и великому князю московскому и воевать против Литвы и Польши. Дивей ответил, что готов служить, но требовал присылать ему поминки в таком же размере, как и его деду Темиру князю, «как де был дед мой на своём юрте в Нагаех». Посол Афанасий ответил, что Темир был сам государь на своём юрте, а Дивей служит крымскому хану, но, если он станет служить царю и великому князю, то ему будут присылать жалованье больше чем другим крымским князьям. Дивей говорил: «Дед мой Темир князь был на своём юрте в Нагаех. А как де над дедом моим сталась незгода, и он поехал служить к астараханскому царю. И дед де и отец государя вашего к деду моему в Азторохань посылали поминки те ж, что и в Нагаи. А яз де здесь не добре ж худ: здесь де меня царь Девлет-Кирей деда моего и отца моего княженьем и местом пожаловал, и государю де вашему добро меня потому ж пожаловать, как деда моего Темиря князя». Посол продолжил склонять князя воевать против польско-литовского короля и обещал поминки при условии реальных дел, однако в цене не сговорились ${ }^{14}$. Кроме того, Дивей претендовал на власть в Астраханском ханстве при царевиче Гирее, в случае передачи Иваном IV этой территории Крыму. Всё это определило антимосковскую позицию князя Дивея. На заседаниях дивана он начал резко выступать против замирения с Москвой, поддерживать требования о передаче Крыму Казани и Астрахани $[9, \text { с. } 126 ; 10 \text {, с. } 42 ; 11, \text { с. } 62]^{15}$.

В октябре 1564 года Девлет-Гирей с царевичами подходил к Рязани. Дивею поручили идти в авангарде, атаковать Зарайск и переправиться через Оку, но сделать этого ему не удалось. Планы сорвали Алексей Басманов и сын его Фёдор, оказавшиеся с сотней людей в своих рязанских поместьях. Они неожиданно для татар стали наносить удары по их загонным отрядам. Хан подумал, что подошли русские полки и приказал стягивать все силы к Рязани. Дивей говорил хану: «Город де ветхий, а людей в нём мало. Однолично город возьмём». Хан стоял у крепости в нерешительности. Дивей же хотел действия и говорил татарам: «собирайтеся, хотя царь от Рязани и поворотит, а мне однолично быти за рекою» ${ }^{16}$.

Ходил он и в поход Девлет-Гирея осенью 1565 г. на Болхов [49, с. 399] ${ }^{17}$.

Находившиеся под управлением князя Дивея силы мангытов были значительными. Польско-литовский дипломат Андрей Тарановский сообщает, что в походе на Астрахань в 1569 г. участвовало до 30 тыс. ногаев [29, с. 483]. Большая часть из них, очевидно, относилась к крымским мангытам. Дивей не хотел установления османского влияния в Нижнем Поволжье и поддержал хана в саботировании этого предприятия [11, с. 62]. Не без его усилий турецко-крымский поход на Астрахань закончился провалом.

\footnotetext{
${ }^{13}$ РГАДА. Ф. 123. Сношения России с Крымом. Кн. № 11 Л. 208 об.

${ }^{14}$ РГАДА. Ф. 123. Сношения России с Крымом. Кн. № 11. Л. 230-231.

15 РГАДА. Ф. 123. Сношения России с Крымом. Кн. № 11. Л. 235 об., 242-243.

${ }^{16}$ РГАДА. Ф. 123. Сношения России с Крымом. Кн. № 11. Л. 134-135 об.

${ }^{17}$ РГАДА. Ф. 123. Сношения России с Крымом. Кн. № 10. Л. 126; Кн. № 11. Л. 299.
} 
Весной 1571 года Дивей был военачальником в успешном походе на Москву, завершившимся ее сожжением и ограблением окрестностей. Интересные сведения о вторжении имеются в необычном источнике - «Ироничных “посланиях" Посольского приказа турецкому султану». Хотя он и относится к литературным сочинениям начала XVII в. с вымышленным сюжетом, в нём использованы реальные исторические материалы, что должно было придать произведению видимость правдоподобности. Согласно тексту, Иван IV через посла в Турции Андрея Ищеина-Кузьминского жаловался султану «на его посаженика на Менгирея царя и на калгу царевича на крымского, что они приходили на Русь с мурзы и с шириньскими князи и с казыевым улусом, и Дивей с детми, и Бакай мурза с тотары, и изовские, турские, и азовские татарове и казаки и Золотые Болшие Орды заволские нагаи смаленвы и Тоехматовы дети, Урус, и Урмет, и Кенбай, и Тебмай, и Кучюк мурза и Шихдамет и Шостербрат с своими мурзы, и с кочевыми тотары, и со всеми крымскими и нагайскими мурзы и тотары, и иных орд с прибилными людми чрез крестное целованье и чрез мирное стоянье ... пришли в мою землю войною и повоевали, и Москву град пожег» [75, с. 405-406].

Скорее всего, Дивей участвовал и в других походах, когда против Руси поднимался «весь Крым»: даже если его имя источниками не называется, но среди участников упоминаются крымские мангыты.

Ходил он в походы и на другие страны. В 1566 году русские послы Афанасий Нагой и Фёдор Писемский сообщали из Крыма, что осенью нападения татар не будет, т. к. все «лутчие люди», в том числе и князь Дивей, участвуют в венгерском походе ${ }^{18}$.

В мае 1565 года с гонцом Акинчеем Дивей присылал письмо Ивану Грозному $^{19}$. В декабре 1570 года вновь присылал с крымским посольством письмо и получил ответ. Ничего примечательного в переписке не было: обычное заверение о желании добра и мира между государями и о «лёгких поминках» $[54$, с. 279,305$]$.

Летом 1572 года Девлет-Гирей предпринял грандиозный поход на Россию. Непосредственно войском руководил карачи-бек Дивей. Крымский хан шёл не в простой грабительский набег. Он предполагал отторгнуть от России территории бывших Казанского и Астраханского ханств и поставить Москву в такую же зависимость, как и во времена Золотой Орды. Цель похода определила необычную настойчивость татар и ожесточённость сражений.

До нас дошла уникальная историческая песня «Набег крымского хана». Исследователи вслед за В.Ф. Миллером связывают её с событиями 1572 года $[28$, с. $572 ; 38$, с. $244-245 ; 65$, с. 465$]$. Есть основания думать, что в песне всё же рассказывается о приходе к Москве хана Газы-Гирея II (1588-1607) в 1591 году. Сами события и их результаты очень схожи, что и определило ошибку. Тем не менее, песня будет полезна нам не только для иллюстрации.

Песня сохранилась в единственном экземпляре в тетради английского дипломата Ричарда Джемса (Джеймса) (1582-1638), побывавшего в России в 1618-1620 гг. с посольством к царю Михаилу Фёдоровичу (1613-1645). Он интересовался Россией и её народами, составлял словарь, фиксировал крат-

\footnotetext{
${ }^{18}$ РГАДА. Ф. 123. Сношения России с Крымом. Кн. № 12. Л. 224 об.

${ }^{19}$ РГАДА. Ф. 123. Сношения России с Крымом. Кн. № 11. Л. 336 об. - 337.
} 
кие сведения по истории, этнографии и культуре и песни. Интересующая нас песня записана для не знавшего русского языка дипломата в 1619/20 г. какимто образованным русским человеком. Ценна песня тем, что сочинена сразу же после события. Даже когда производилась запись, оставались ещё живы участники. Поэтому песню с полным основанием можно отнести к нарративным источникам. В песне совещание хана со своими военачальниками перед походом передаётся так:

«А нынечи мы поедем к каменной Москве,

А назад мы пойдём, Рязань возьмём».

А как будут они у Оки-реки,

А тут они станут белы шатры расставливать.

«А думайте вы думу с цела ума:

Кому у нас сидеть в каменной Москве,

А кому у нас в Володимере,

А кому у нас сидеть в Суздале,

А кому у нас держать Рязань Старая,

А кому у нас в Звенигороде,

А кому у нас сидеть в Нове-городе?» [28, с. 132; 38, с. 244; 65, с. 74-75]

Единственный персонаж песни, названный по имени - главный советник хана «Диви-мурзы сын Уланович». Как видим, это не сам Дивей, а его сын, видимо, участвовавший в походе 1591 г. во главе ногайцев Арсланай. На вопросы хана он даёт такие ответы:

«А еси государь наш Крымский царь!

А тобе, государь, у нас сидеть в каменной Москве,

А сыну твоему в Володимире,

А племяннику твоему в Суздале,

А сродичу в Звенигороде,

А боярину конюшему держать Рязань Старая,

А меня, государь, пожалуй Новым-городом...» [28, с. 132; 38, с. 245; 65 , c. 75]

Основания просить Арсланаю у хана Новгород были, но об этом ниже.

26 июля крымское войско вышло к Оке у Серпухова и попыталось её форсировать у Сенькина брода. Но здесь татар встретили сильным пишальным и пушечным огнём, да и сам брод был заранее «заминирован» с помощью «чеснока» - специальных железных изделий с острыми шипами, затруднявших передвижение противника. На следующий день Дивей нанёс удары по русским с флангов. Сам он переправился через реку у села Дракино, Тягрибердей-мурза смог пройти через Сенькин брод. Девлет-Гирей в это время с основными силами связал боем русских в центре и не позволил им оказать помощь атакованным флангам. В ночь на 28-е хан, оставив напротив Серпухова две тысячи воинов, обоз и артиллерию, переправился по занятому уже Сенькину броду. Крымцам удалось обойти основные русские силы и начать наступление на Москву. Тягрибердей-мурза со своими ногайцами приблизился к Москве и занял все дороги. При этом он не распустил отряды для грабежа и поджогов, поджидая основные силы [4, с. 270]. Однако в тылу у крымцев осталось русское войско, стоявшее до этого по берегу Оки. Оно стало преследовать татар и наносить чувствительные удары по арьергарду. Хан хотел скорее идти к Москве, однако его военачальники во главе с Дивеем 
понимали, что опасно оставлять в тылу столь сильную группировку противника, и настаивали на приостановлении наступления и необходимости разгрома русского войска воевод Михаила Ивановича Воротынского (ок. 15161573 ) и Дмитрия Ивановича Хворостинина (ок. 1535-1591). Крымские татары не любили ввязываться в полевые сражения, но необходимость устранить угрозу с тыла была очевидна. Хан развернул войско и ударил по русским. У татар имелось двукратное превосходство в силах, поэтому русские стали уклоняться от сражения на открытой местности. Отступая, русские воины вывели татар и ногайцев на заранее подготовленные позиции у Молодей к гуляй-городу под огонь пушек и пищалей. Здесь и состоялась Молодинская битва, в очередной раз решившая судьбу России.

29 июля стороны производили разведку боем, отдельные сотни вели перестрелку из луков, не доводя дело до рукопашной схватки. Русские не собирались покидать своего укрепления, занимая удобную позицию на холме под защитой рва, вала и гуляй-города. На совещании у хана Дивей заявил: «Яз обоз руской возьму; и как ужаснутца и здрогнут, и мы их побием». 30 июля после нескольких безуспешных атак русских позиций Дивей выехал на рекогносцировку, пытаясь найти слабое место в обороне противника. Русские, увидев вблизи небольшой отряд врага, совершили вылазку. Уходя от погони, конь под Дивеем споткнулся, а подскакавший к упавшему суздальский сын боярский Иван (Тимур) Шибаев сын Алалыкин захватил его в плен. Русские не сразу поняли, кто оказался у них в руках. Сам Дивей назвался мелким мурзой [52, с. 225; 66, стб. 287]. Выдать себя за простого воина он не мог изза богатой экипировки и породистого аргамака.

Пленение Дивея вызвало шок среди татар и ногайцев. Только к вечеру они возобновили атаки, которые уже не были такими сильными как днём. В этих атаках татары понесли новые серьёзные потери, погиб Тягрибердеймурза и попал в плен астраханский царевич из эмигрантов. Московский летописец так передаёт результаты боя: «Да тут же взяли Ширинбака царевича и привели к бояром. И бояря стали спрашивать: “Что царево умышление?” И он им сказал: “Яз де хотя и царевичь, а думы царевы не ведаю, дума де царева ныне вся у вас, взяли вы Дивия мурзу, тот был всему промышленник”. И бояре велели сводить языки. И как привели Дивея мурзу, и царевичь стал перед ним на коленках и боярям указал: “То Дивей”» [52, с. 225].

Участник событий сотник немец Генрих Штаден несколько иначе передаёт эпизод опознания: «Мы захватили в плен главного военачальника крымского царя Дивей-мурзу и Хаз-булата. Но никто не знал их языка. Мы [думали], что это был какой-нибудь мелкий мурза. На другой день в плен был взят татарин, бывший слуга Дивей-мурзы. Его спросили - как долго простоит [крымский] царь? Татарин отвечал: “Что же вы спрашиваете об этом меня! Спросите моего господина Дивей-мурзу, которого вы вчера захватили”. Тогда было приказано всем привести своих полоняников. Татарин указал на Дивея-мурзу и сказал: “Вот он - Дивей-мурза!”. Когда спросили Дивеймурзу: “Ты ли Дивей-мурза?”, тот отвечал: “Нет! я мурза невеликий!” [73, c. 111]. Но запирался он не долго «и сам сказался. И в полкех учала быти радость великая» [52, с. 225].

Сопоставив два сообщения, полагаю, что большее доверие следует отдать свидетельству Штадена. Мурзу выдал не астраханский царевич, оказав- 
шийся в плену, а всё же слуга. На это указывает как раз Московский летописец, сообщающий, что выдавший Дивея царевич встал при этом перед ним на колени. Каким бы не был высоким авторитет карачи-бека, любой самый никчёмный царевич стоял выше в феодальной иерархии, и вставать на колени перед мурзой или даже князем ему было неприемлемо. Мотивация же слуги и его коленопреклонение понятно. Он опасался дознания с пристрастием, т.е. пыток, и поспешил выдать своего господина, пока это не сделал кто-то другой, тем самым облегчил свою участь в плену. При этом слуга выказал почтение своему господину в соответствии с принятой феодальной этикой.

Дивея допросили о планах хана. Пленник вёл себя высокомерно. «Дивеймурза дерзко и нахально сказал князю Михаилу Воротынскому и всем воеводам: “Эх, вы, мужичье! Как вы, жалкие, осмелились тягаться с вашим господином, с крымским царем!”. Они отвечали: “Ты [сам] в плену, а еще грозишься”. На это Дивей-мурза возразил: “Если бы крымский царь был взят в полон вместо меня, я освободил бы его, а [вас], мужиков, всех согнал бы полоняниками в Крым!”. Воеводы спросили: “Как бы ты это сделал?”. Дивеймурза отвечал: “Я выморил бы вас голодом в вашем гуляй-городе в 5-6 дней”. Ибо он хорошо знал, что русские били и ели своих лошадей, на которых они должны выезжать против врага. Русские пали тогда духом» [73, c. 111]. Сидевшие в гуляй-городе русские испытывали трудности с водой и пищей. Крымцам, по мысли Дивея, для победы следовало проявить выдержку и взять русских осадой. Но то, что хан будет действовать так, сам Дивей сомневался [52, с. 225].

31 июля и 1 августа наблюдалось затишье, нарушавшееся мелкими стычками. Русское командование понимало, что время работает против них, и стремилось вынудить крымцев отступить. Из Москвы в гуляй-город направили грамоту с дезинформацией о подходе из Новгорода войска во главе с самим царём. Нужно отдать должное мужеству и самоотверженности служилого человека, взявшегося выполнить поручение. Как и предполагалось, гонца перехватил татарский разъезд. Даже под пытками обречённый герой подтверждал содержание грамоты. «И начата его спрашивать: “Где государь и хто на Москве, и нет ли прибылых людей?” И он в роспросе сказал: “Государь был в Новегороде, а ныне, собрався с новогороцкою силою и с немцы, идет к Москве. А перед государем при мне пришел боярин и воевода князь Иван Федоровичь Мстиславской, а с ним 40000 войска. И яз пошел, и на Москве учал быть звон великой и стрельба. И, чаю, пришел и государь. А завтра резвые люди будут в полки к бояром"». Это известие совпало по времени с выявлением в плену личности князя Дивея. «А бояря велели перед зарёю из большево наряду стрелять и по набатам и по накрам бить, и в трубы трубить на радости, что Дивея мурзу взяли» [52, с. 225]. Хан принял этот шум за проявление радости в связи с приближением свежего русского войска. Цель ввести в заблуждение хана была достигнута. Девлет-Гирей поверил, что к осаждённым в гуляй-городе русским скоро придёт помощь, и не продолжил осаду, но и отступать тоже не стал. 2 августа он предпринимал отчаянные попытки до подхода русских войск освободить своего карачи-бека. Бой приобрёл необычайно ожесточённый характер. Татары и ногайцы в пешем и конном строю атаковали гуляй-город. Не считаясь с потерями от убийственного огня, они смогли преодолеть ров и взобраться на вал. Воины лезли на 
щиты, пытались их опрокинуть или перелезть, но все атаки заканчивались неудачей и большими потерями. Летописец отмечает, что «нашы стрельцы туто многых татар побили и рук бесчислено татарьскых отсекали» [4, с. 272]. Выждав момент, русские и наёмники немцы совершили удачную вылазку и смелый обходной манёвр, вынудив татар к отступлению. Потерпев поражение, хан вернулся в Крым.

Побежал еси, собака Крымский царь,

Не путём еси - не дорогою,

Не по знамени - не по чёрному [28, с. 132].

Поражение имело тяжкие последствия и для семьи хана. Погибли два сына и внук [4, с. 272; 33, с. 148-149]. А.В. Виноградов полагает, что это были Азамат-Гирей и Сафа-Гирей, т. к. упоминания о них из источников исчезают [33, с. 431$]$.

9 августа пленного князя Дивея доставили в Новгород, где в это время находился царь, и передали «на бережение» князю Борису Давыдовичу Тулупову, который поселил его на улице Рогатице. Известие о грандиозной победе и демонстрация знаменитого пленного крымского военачальника послужили причиной радости и триумфа с колокольным звоном.

Дивей имел сильное влияние на проживавших в ханстве ногайцев, был способен держать их в подчинении. Возглавляемый им род Мансур являлся сильным противовесом родам Ширин, Барын, Аргын и Кипчак. Хан высоко ценил Дивея. «А он нам служил, души своей за нас не щадил, и за нас саблю доводил, и службы его к нам было много», - писал он в Москву [55, с. 225]. Отсутствие признанного лидера могло дистабилизировать политическую ситуацию в Крыму. Пришедший из Крыма в Москву в мае 1576 г. полоняник Истома Ложкин сообщал, что «в Крыме говорят: Нам, деи, ни царь, ни царевичи не дорого, толко б, деи, нам в Крыме Дивей был, потому которые нагайские люди в Крыму живут, и те, деи, нагайские люди были Дивеем верны. А ныне, деи, без Дивея поизменилося. Нагайские люди царю и царевичам не верят, а царь и царевичи нагайским не верят... А Девея просит царь з бойством, - будто не хотя просит, а всех им Дивей нужен для нагайских людей» $[33$, с. $432 ; 55$, с. $220-221]$.

Девлет-Гирей предпринимал неоднократные дипломатические усилия освободить Дивея и даже не поставил на место отца карачи-беком его сына Есинея, что осложнило отношения с мангытами [11, с. 275]. Случай представился в 1573 г., когда в плен попал приближённый царя Василий Григорьевич Грязной-Ильин. Хан предлагал произвести размен пленниками или выкупить. Руководствуясь государственными соображениями, Иван Грозный отклонил предложение. В ответ на просьбу об обмене, присланную В.Г. Грязным, царь отвечал: «А коли б ты сказывался: молодой человек, - ино б на тебе Дивея не просили. А Дивея, сказывает царь, что он молодой человек, а ста тысячь рублев не хочет на тебе мимо Дивея, - Дивей ему ста тысяч рублев лутчи! А за сына за Дивеева дочерь свою дал, а нагайской князь и мурзы ему все братья. У Дивея и своих таких полно было как ты, Вася. Опричь было князя Семена Пункова не на ково меняти Дивея, ано и князя Михаила Васильевича Глинъского нечто для присвоенья меняти было. А то в нынешнее время неково на Дивея меняти. Тебе, вышедчи ис полону, столко не привести татар, ни поимать, сколько Дивей кристьян пленит. И тебя, ведь, на Дивея выменити не 
для кристьянства - на кристьянство: ты один свободен будешь, да приехав по своему увечью лежать станешь, а Дивей приехав учнёт воевати да неколко сот кристьян лутчи тебя пленит. Что в том будет прибыток, коли еси сулил мену не по себе, и писал? И что не в меру, и то, как дати? То крестьянъству не пособит - разорить крестьянъство, что неподобною мерою зделать. А что будет по твоей мере мена или окуп, и мы тебя тем пожалуем. А будет станешь за гордость на крестьянъство, - ино х тебе противник» [53, с. 194, 371; 55, с. 168]. Но и после этого Девлет-Гирей в дипломатических переговорах неоднократно поднимал вопрос об освобождении князя Дивея посредством размена или выкупа [55, с. 183, 187, 189-190, 220-222, 225-226, 228-229, 231-234, 241, 244, 247-250, 252, 282 $]^{20}$. В августе 1574 г. отъезжавшему в Крым гонцу Ивану Мясоедову в наказе о Дивее требовалось говорить: «А ныне Дивей у государя нашего в отсылке вь его вотчине в Великом Новегороде» [55, с. 174].

Переговоры о судьбе Дивея-мурзы завершились в ноябре 1576 г. после заявления Ивана Грозного в письме к хану о его смерти: «слуга твой Дивей был у нас в руках, да в животе его не стало тому другой год» [33, с. 431; 55, c. 244, 249-250, 252, 282, 291]. Получается, что карачи-бек умер в 1575 году. Н.M. Карамзин пишет, что царь сожалел о смерти Дивея, «ибо хан готов был клятвенно утвердить союз с нами для освобождения сего важного пленника, уже не требуя Астрахани» [30, с. 87]. Пожалуй, не соглашусь с именитым историком. Иван Грозный не имел иллюзий в отношении клятвенных заверений крымского хана и знал им цену. Поэтому если и были сожаления царя по поводу смерти пленника, то только показные, рассчитанные на послов. Москва практически никогда не отпускала опасных чем-либо или нужных для неё иностранцев. И хотя в Посольском приказе не уклонялись от обсуждения их судьбы, подозрительно часто после достижения соглашения они умирали. Это и казанский хан Абдул-Латиф и казанский посол Елюка, крымский посол Ян-Болдуй и другие. Не вернулись на свою тёплую родину Максим Грек и Аристотель Фиораванти. Несмотря на многочисленные требования из Ногайской Орды, фактически в заключении закончила свои дни в Касимове последняя казанская царица Сююмбике. Список можно продолжить.

Вроде бы всё ясно, крымская сторона удовлетворилась заявлением и более судьбы Дивея-мурзы не касалась. Длительное время никто не ставил под сомнение факт его смерти. В 1925 году И.И. Полосин (1891-1956) впервые опубликовал на русском языке сочинение немца-опричника Генриха фон Штадена. В комментариях он отождествил Дивея-мурзу с упоминаемым иностранными авторами Р. Гейденштейном, П. Одерборном и Градовским Даниилом-мурзой. По словам И.И. Полосина, Дивей «был доставлен в Новгород к царю Ивану и позже перешел к нему на службу; в чине постельника (или стольника?) был с ним в Старице в 1581 г. во время осады Пскова. В набег на царскую ставку Христофора Радзивилла перебежал в отряд последнего, изменив царю. Видимо, был принят на службу Баторием. Дальнейшая его судьба неизвестна» [73, с. 157].

После этого сообщения о «посмертной» службе Дивея русскому царю стали проникать в научную литературу, хотя авторы иногда делали оговорки о неясно-

${ }^{20}$ РГАДА. Ф. 123. Сношения России с Крымом. Кн. № 15. Л. 2 об. 
сти вопроса [19, с. 81; 64, с. 169]. В комментариях к новому изданию сочинения Генриха Штадена указывается о судьбе Дивея после пленения: «Дивей же поступил на царскую службу и в 1581 г. находился в Старице при царском дворе. Воспользовавшись набегом Хр. Радзивилла, в 1581 г. бежал и поступил на службу Стефану Баторию» [74, с. 290]. А.А. Дудин в книге «Молодинская битва» тоже поддержал идентификацию Дивея с Даниилой-мурзой [21].

Полагаю, что нет достаточных оснований считать, что видный крымский аристократ оставался в живых после 1575 года.

Сначала о личности Даниила-мурзы, упоминаемого иностранными авторами и отождествлённого И.И. Полосиным и последователями с будто бы принявшим христианство и поступившим на русскую службу Дивеем. Поступление на службу к русскому царю и смена веры, в том числе пленными, не было уж столь редким явлением. Однако не в этом случае. Упомянутый Даниил-мурза является известной историкам личностью. Это Даниила Мурзин Кубкеев (Купкеев, Купкелев, Купочеев, Пубкеев, Кубков), потомок выезжих на русскую службу татар. В разрядной книге уточняется, что он «тотарин нагайской» [60, с. 278]. О нём известно немного, но достаточно для того, чтобы понять, что это не Дивей. Даниила Кубкеев был намного моложе Дивея и многократно упоминается в источниках. Он служил при дворе царя жильцом, т. е. занимал не высокую должность и входил в служилую массу, поэтому не сопоставим по статусу с карачи-беем Дивеем. В то же время он входил в первую наиболее высокооплачиваемую группу служебников и получал 50 рублей годового жалования, что отражено в списке служилых людей с указанием их жалования, составленном 20 марта 1573 года [70]. Примечательно, что с таким же жалованием и в тех же должностях в это время при дворе проходил службу 20-тилетний Борис Фёдорович Годунов, будущий царь. Даниил Кубкеев, видимо, находился в этих же летах.

На службе он числился ещё до пленения Дивея. Впервые упоминается в походе царя и царевича Ивана к Серпухову в сентябре 1570 г. как поддатень $[58,236 ; 60$, с. 278$]$. Поддатни служили помощниками и подносили оружие, боеприпасы, снаряжение. Они были не только при царствующих особах и воеводах, но и возле артиллерии и др., являлись оруженосцами и составляли резерв. В мае 1571 года Даниил Кубкеев участвовал в походе царя и царевича из Слободы к Оке в качестве оруженосца - «поддатень к доспехи» [58, с. 239; 60 , с. 278]. Его имя есть в росписи свадьбы царя с Марфой Васильевной Собакиной в октябре 1571 года. Он должен был «над государевою свечёю нести фонарь» [60, с. 289]. Поддатнем он расписан в весенний поход 1572 г. из Новгорода против шведов [58, с. 243; 60, с. 303; 63, с. 72, 79]. В 1576 году поддатнем у рынды участвует в походе на берег Оки. В той же должности он в походе 1577 г. против Речи Посполитой выполнял охранную ночную службу у государя [58, с. 260; 60, с. 442; 61, с. 455]. В 1581 году Даниил как «дворцовый жилец» присутствует на приёме царём посланца папы римского Антонио Поссевино [42, с. 177].

Из сообщения Рейнгольда Гейденштейна известно, что в 1581 г. во время рейда литовского воеводы Христофора Радзивилла к Старице, где находился сам царь Иван Грозный, к ним перебежал Даниил-мурза: «В это время перешел на нашу сторону некто Даниил Мурза (Daniel Mursa), один из стольников Московского царя; о количестве войска у царя он сообщал тоже самое, что 
уже было известно прежде по слухам и из речей пленных, а при том еще во многом прихвастнул от себя; тем не менее наши, вследствие укоренившегося мнения о великом могуществе такого государя, легко поверили его словам; и вот, когда нашим представлялась возможность совершить достопамятный подвиг, если бы они подошли к Старице, они вернулись назад, считая свои силы недостаточными в сравнении с войском, которым, предполагалось, была ограждена жизнь и безопасность могущественного монарха; они направились к Двине, а оттуда достигли Дубна, измученные большими трудностями этого пути» $[16$, с. 221]. Подтверждает переход к литовцам Даниила-мурзы и Павел Одеборн [45, с. 206]. Получается, что своим рассказом, имевшим только цель подчеркнуть собственную значимость, Даниил-мурза непреднамеренно ввёл поляков и литовцев в заблуждение и способствовал их отступлению. Если, конечно, это были не сознательные действия по срыву предприятия Радзивилла. Но факт, что перебежчик оказался на польской службе.

Уже после смерти Ивана Грозного при царе Фёдоре мурзе Кубкееву и другим эмигрантам в Речи Посполитой посылались «милостивые грамоты» с обещанием забвения вины, чинов и жалованья, «если они с раскаянием и с усердием явятся в Москве, чтобы доставить нам все нужные сведения о внутреннем состоянии Литвы, о видах и способах ее политики» [30, с. 220]. Очевидно, Даниил-мурза Кубкеев, опасаясь наказания за предательство, так и не вернулся в Россию, разве что с самозванцами и интервентами в Смуту, но к тому времени ему уже должно было исполниться около 60-ти лет - не лучший возраст для очередного зигзага в судьбе. Совершенно ясно, что князь Дивей и Даниил-мурза - разные люди. А.В. Виноградов отмечает, что версия о нахождении Дивея в Старице и бегстве его к полякам «не находит подтверждения в польско-литовских источниках» [33, с. 431-432].

Известие о здравствовании Дивея после 1575 г. как будто подтверждается письмом литовского пана брацлавского кастеляна Василия Загоровского А.М. Курбскому от 1577 года. В этом письме попавший в плен к татарам В. Загоровский обращается к князю с просьбой о выкупе, просит позаботиться о его семье и несколько раз указывает, что он попал в плен к людям Дивея возле Пскова. Копия с письма была записана в «Книге гродской Владимирской 1577 года» 22 апреля (Л. 37 об. - 39), хранившейся в Киевском архиве. В 1849 году письмо опубликовали [26, с. 286-290; 27, стб. 514]. В 1951 году, публикуя послания Ивана Грозного, Я.С. Лурье в своих комментариях отметил, что «сражаться с войсками Речи Посполитой и находиться под Псковом в 1577 г. Дивей-мурза мог только в рядах русской армии» [53, с. 641].

Чтобы разобраться, необходимо привести выдержки из письма. Пленник пишет, что он «впал за грехи свои, в руки людей царевича крымскаго, а именно в руки князя Девия мурзы <.. > Хотя ещё не назначили за меня выкупа, но отложили на благоусмотрение царя, его милости; несмотря на то, я уже бил челом, чтоб с меня, как с человека убогаго, взяли четыреста червонцов, а наконец я предлагал пятьсот <..> А вышеупомянутые червонцы, <..> изволь вручить пану Бокию. Я писал к нему, чтобы он эти пятьсот червонцов вместе с деньгами, назначенными для выкупа брата его, пана Фёдора Бокия, послал чрез слугу моего Марка, который отправится с каким нибудь купцом в Крым или в другое место, где царь находиться будет. Дано на поле, недалеко от Пьскоива» [27, стб. 514-520]. 
Как видно, текст не даёт однозначного толкования в пользу гипотезы о здравствовании Дивея-мурзы. Василий Загоровский явно попал в плен к его сыну. Выкуп следует доставить в Крым или в иное место, где будет находиться царь. Последнее указывает, что речь идёт о крымском хане, для которого естественно находиться в Крыму, а вот для русского царя Ивана - нет. Следует отметить и то, что в Речи Посполитой не принято было называть Ивана IV царём из-за непризнания такого более высокого титула, чем великий князь московский. Примечательно, что эмигрант А.М. Курбский своё сочинение назвал «История о великом князе московском». Единственное, что смущает в письме, это указание на место написания письма: «на поле, недалеко от Пьскоива». Полем обычно называли южнорусскую степь (Дешт-и Кипчак) за пределами Крыма. Это явно не лесистые окрестности Пскова. Скорее всего, это где-то в Северной Таврии, какое-то урочище или речка в местах кочевий крымских мангытов. Возможно, имеется в виду левый приток Днепра Псёл. Следует обратить внимание на то, что название реки в источниках нередко искажалось. В Академическом и Евреиновском списках разрядной книги 1559-1605 гг., например, записано не «на Псле», а «на Псове» [58, с. 186]. Остается добавить одну букву «к», и река превратится в город Псков. Из разрядов следует, что река Псёл служила татарам местом сосредоточения для нападения на стародубские и почапские места [58, с. 238]. Ещё в 1563 г. русские под давлением татар и литовцев оставили построенный на этой реке городок $[14$, с. 146]. Следует учесть, что как раз в указанные годы обострились отношения между «черкасами» и мангытами, отмеченные взаимными нападениями [11, с. 63]. Крымские татары часто промышляли на этой реке, захватывая пленных [55, с. 60].

Дополнительным указанием на то, что описываемые события относятся к крымским татарам, служит упоминание подкомория (судьи) ВладимироВолынского воеводства Федора Бокии Печихвостского. Известно, что он находился в плену у крымцев и в том же году был освобождён казачьим атаманом Иваном Подковой [66, с. 368]. Василий же Загоровский так и не дождался освобождения и умер в крымском плену 29 февраля 1580 года [26, с. 290].

На обстоятельства смерти Дивея проливает свет побывавший в России в 1588-1589 гг. в качестве английского посла Джильс Флетчер (1548-1611). Он пишет, что русские обыкновенно обещали пленным татарам жизнь при условии крещения, хотя больших успехов при этом не достигали. «На другой год после того, как крымские татары сожгли Москву, - пишет Флетчер, - был взят в плен какой-то Дивей-мурза, один из начальников, бывших в этом походе, с 300 других татар, и всем им обещали сохранить жизнь, если они согласятся окреститься по русскому обряду; но все они отказались, осыпая упреками тех, которые старались их к тому склонить. Тогда уже повели их всех к Москве-реке (протекающей через город) и окрестили самым жестоким образом: ударяя по голове, бросали их в воду, для чего была нарочно сделана во льду прорубь» [72, с. 135-136]. Указание на прорубь свидетельствует о зимнем времени совершения казни.

Флетчер не был современником события, в России находился всего восемь месяцев, русского языка не знал, поэтому неизбежно мог в чём-то ошибаться. Уникальное известие о смерти Дивея и его единоплеменников, скорее всего, получено послом от кого-то из соотечественников. Находясь в Москве, он мог 
привязать сообщение к этому же городу. Известно, что Новгород служил местом и заключения пленных татар и их казни. Так в январе 1555 г. согласившихся креститься пленных татар распределили по монастырям, а «которые не захотели креститись, ино их метали в воду»[48, с. 157]. Н.М. Карамзин считает, что «Дивий умер невольником в Новегороде» [30, с. 87]. В цитированной уже выше песне указывается то же место смерти Дивея. Его сын, прося хана пожаловать ему Новгород, приводит такое обоснование:

«У меня лежат там свет-добры-дни батюшка,

Диви-мурза сын Уланович» [28, с. 132; 38, с. 245; 65, с. 75].

Так в начале 1575 г. закончил свои дни, скорее всего, в Новгороде один из последовательных и ярых противников Русского государства, не смирившийся и не изменивший ни хану, ни вере, не своему государству.

Поражение крымцев в Молодинской битве и пленение Дивея способствовало началу политической дестабилизации в Крыму и, как следствие, не только снижению агрессивности ханства в отношении России, но и вообще активного участия в военно-политических конфликтах в Восточной Европе. До этого высокий авторитет хана Девлет-Гирея упал. С его смертью в 1577 г. в Крыму началась междоусобица, активное участие в которой приняли сыновья Дивея Есиней и Арсланай [33, с. 432]. Поражение крымцев способствовало окончательному закреплению Среднего и Нижнего Поволжья за Россией. Разгоревшееся в 1572 г. в районе Казани очередное сильное черемисское восстание (Вторая Черемисская война), начавшееся в расчёте на иностранную военную помощь, крымцы поддержать не смогли [8, с. 414]. Только через 19 лет после Молодинской битвы в 1591 г. крымские татары в последний раз смогли дойти до стен Москвы и вновь потерпели неудачу.

Одновременно в том же Крыму имелся тёзка Дивея-мурзы. С 1 сентября 1538 года в Москве находился с посольством от Сахиб-Гирей хана некий Дивей-мурза $[49, \text { с. 125] }]^{21}$. В 1547 году он вновь с посольством прибыл в Москву, попал там под арест и только через год возвратился в Крым [46, c. 103$]^{22}$. В подчинении ногайского Ак-мурзы тоже находился Дивей [54, c. 253].

Популярность имени Дивея-мурзы была такова, что сыновей карачи-бея называли Дивеями, а титул главы рода приобрёл форму «дивей-мурза», и сам род стал называться уже не Мансуровым, а Дивеевым, т. к. потомки Дивея оказались его единственными продолжателями [11, с. $275,281,283 ; 12$, с. 56; 20 , с. 46, 84-85, 87, 104, 106, 115, 338, 340; 27, стб. 514-520; 72, с. 106, 111]. С.Б. Веселовский отмечает, что «в XIV-XVII вв. во всех слоях русского общества было очень распространено обыкновение давать детям сверх христианского имени еще прозвища... по каким-либо прославившимся современникам соседних с Русью народов». Прозвище Дивей появилось у двух помещиков Рязанского уезда, арзамасского помещика Дивея Порошина-Лазарева, костромского помещика Дивея Васильевича Бахтиара [6, с. 228; 7, с. 96]. Известен и татарский род Дивеевых на русской службе, восходящий к князю Дивею Бутакову сыну Мокшеву, показавший себя в казанских походах. Служилые татарские мурзы рода Дивеева проживали в Кадомском уезде на Ря-

\footnotetext{
${ }^{21}$ РГАДА. Ф. 123. Сношения России с Крымом. Кн. № 8. Л. 529 об., 551 об., 557-558.

${ }^{22}$ РГАДА. Ф. 123. Сношения России с Крымом. Кн. № 9. Л. 51 об.
} 
занщине и в Мордовии, расселились по многим губерниям [15, с. 282]. Село Дивеево на Нижегородчине стало местом православного паломничества. В настоящее время существует русская фамилия Дивеев [18, с. 146]. Но всё это не имеет отношения к мангытскому карачи-беку Дивею.

\section{СПИСОК ЛИТЕРАТУРЫ}

1. Абдужемилев P.P. Реммаль Ходжа. Хроника «Тарих-и Сахиб Герей хан» («История о хане Сахиб Герае») Ч. 1 // Крымское историческое обозрение. Казань; Бахчисарай, 2018. № 1 (10). С. 179-195; Ч. 2. № 2 (11). С. 193-233.

2. Акчурин М.М. Административно-территориальное устройство Мещеры XV - начала XVII веков (Этнополитические аспекты). Казань, 2019. 257 с.

3. Андреев А.Р. Неизвестное Бородино. Молодинская битва 1572 года. Документальная хроника XVI века. М: Межрегиональный центр отраслевой информатики Госатомнадзора России, 1997. 252 с.

4. Буганов В.И. Повесть о победе над крымскими татарами в 1572 году // Археографический ежегодник за 1961 год. М., 1962. С. 259-275.

5. Бурдей Г.Д. Молодинская битва 1572 года // Из истории межславянских культурных связей. Ученые записки института славяноведения. М., 1963. Т. 26. C. 48-79.

6. Веселовский С.Б. Исследования по истории класса служилых землевладельцев. М.: Наука, 1969. 583 с.

7. Веселовский С.Б. Ономастикон. Древнерусские имена, прозвища и фамилии. М.: Наука, 1974. 382 с.

8. Виноградов А.В. Русско-крымские отношения Смутного времени // История Крыма: в 2 т. М.: Фонд «Связь Эпох», 2017. Т. 1. С. 406-417.

9. Виноградов А.B. Русско-крымские отношения 50-е - вторая половина 70-х годов XVI века. М.: Институт российской истории Российской Академии наук, 2007. T. $1.199 \mathrm{c}$.

10. Виноградов A.B. Русско-крымские отношения 50-е - вторая половина 70-х годов XVI века. М.: Институт российской истории Российской Академии наук, 2007. T. $2.342 \mathrm{c}$.

11. Виноградов А.В. Русско-крымские отношения в 1570-1590-х гг. в контексте династического кризиса Гиреев // Средневековые тюрко-татарские государства. Сборник статей. Казань, 2010. Вып. 2. С. 274-299.

12. Виноградов A. B. Северное Причерноморье в XVI в. в контексте развития международных отношений в Восточной Европе // История Новороссии: (Крым в истории, культуре и экономике России) / Захаров В.Н. (ред.). М.; СПб.: Центр гуманитарных инициатив, 2017. С. 55-69.

13. Виноградов А.В., Малов А.В. «Сошлись с ними у Воскресенья в Молодех»: Материалы о походе Девлет-Гирея I на Москву 1572 г. в Крымской посольской книге 1571-1578 гг. // Единорогъ: Материалы по военной истории Восточной Европы эпохи Средних веков и Раннего Нового времени. М.: Квадрига, 2011. Вып. 2. С. 202-253.

14. Волков В.A. Войны и войска Московского государства. М.: Эсмо, Алгоритм, 2004. $576 \mathrm{c}$.

15. Габдуллин И.Р. Дивеевы // Татарская энциклопедия: в 6 т., Т. 2: Г-Й / Хасанов М.Х. (ред.). Казань: Институт татарской энциклопедии, 2005. С. 282.

16. Гейденштейн Рейнгольд. Записки о Московской войне. СПб., 1889. 312 с.

17. Гирай Халим султан. Розовый куст ханов, или история Крыма = Gulbun-i hanan yahut Qirim tarihi: историческая литература [Текст] / Усеинов К. (пер.); Сейтягъяев Н.С. (ред.). Симферополь: Доля, 2004. 228 с. 
18. Грушко Е.А., Медведев Ю.М. Словарь фамилий. Нижний Новгород: «Три богатыря» и «Братья славяне», 1997. 592 с.

19. Гусев В.И. «Чтобы чужие люди... безвестно не приходили» // Военноисторический журнал. М., 1997. № 5. С. 76-81.

20. Документы Крымского ханства из собрания Хусейна Фейзханова / Абдужемилев Р.Р., Миргалеев И. (ред.). Симферополь: ООО «Константа», 2017. 816 с.

21. Дудин А.А. Молодинская битва. М.: Научная библиотека, 2016. 130 с.

22. Ерусалимский К.Ю. На службе короля и Речи Посполитой. М.; СПб.: НесторИстория, 2018. $1012 \mathrm{c}$.

23. Жирмунский В. М. Тюркский героический эпос. Л.: Наука, 1974. 727 с.

24. Зайцев И.В. Крымская историографическая традиция XV-XIX веков: пути развития: рукописи, тексты и источники. М.: Восточная литература, 2009. 304 с.

25. Зайцев И.В. Между Москвой и Стамбулом. Джучидские государства, Москва и Османская империя (нач. XV - пер. пол. XVI вв.). Очерки. М., 2004. 216 с.

26. Иванищев Н.Д. Жизнь князя Андрея Михайловича Курбского в Литве и на Волыни. К., 1849. Т. 2. 364 с.

27. Из книги гродской Владимирской 1577 года / Сочинения князя Курбского, T. 1: Сочинения оригинальные // Русская историческая библиотека, издаваемая Императорской Археографической комиссией. СПб., 1914. Т. 31. Стб. 513-564.

28. Исторические песни. Баллады / Азбелёв С.Н. (ред). М.: Современник, 1986. $622 \mathrm{c}$.

29. История о приходе турецкаго и татарскаго воинства под Астрахань в лето от Р. Х. 1677 //Записки Одесскаго общества истории и древностей. Одесса, 1872. Т. 8. C. $479-488$.

30. Карамзин Н.М. История государства Российского. Калуга: Золотая аллея, 1995. T. IX-XII. 592 c.

31. Каргалов В.В. Русь и кочевники. М.: Вече, 2004. 528 с.

32. Кром М.M. Судьба авантюриста: князь Семён Фёдорович Бельский // Очерки феодальной России. М., 2000. Вып. 4. С. 98-115.

33. Курбский Андрей. История о делах великого князя московского / Рыков Ю.Д. (ред.). М.: Наука, 2015. 943 с.

34. Курбский А.М. История о великом князе Московском / Сочинения князя Курбского, Т. 1: Сочинения оригинальные // Русская историческая библиотека, издаваемая Императорской Археографической комиссией. СПб., 1914. Т. 31. С. 161-354.

35. Лызлов А.И. Скифская история. М.: Наука, 1990. 519 с.

36. Малиновский А.Ф. Историческое и дипломатическое собрание дел, происходивших между российскими великими князьями и бывшими в Крыме татарскими царями с 1462 по 1533 год, приложение № 37 // Записки Одесского общества истории и древностей. Одесса, 1863. Т. 5. С. 178-419.

37. Малоизвестные летописные памятники XVI в. // Тихомиров М.Н. Русское летописание. М.: Наука, 1979. С. 220-229.

38. Миллер В.Ф. Исторические песни русского народа XVI-XVII вв. Пг.: Типография Императорской Академии наук, 1915. 793 с.

39. Моисеев М.В. Касимов, «Мещерские места» в русско-ногайских отношениях XVI столетия // Третьи Яхонтовские чтения. Материалы научно-практической конференции. Рязань, 2005. С. 414-422.

40. Моисеев М.В. Шертные грамоты в контексте русско-ногайских отношений в XVI веке // Средневековые тюрко-татарские государства. Казань, 2014. № 6. С. 84 90.

41. Молодинская битва // Славянская энциклопедия. Киевская Русь - Московия: в 2 т. М., 2005. Т. 1. С. 745-746. 
42. Мордовина С.П., Станиславский А. Л. Состав особого двора Ивана IV в период «великого княжения» Симеона Бекбулатовича // Археографический ежегодник за 1976 год. М., 1977. С. 153-191.

43. Некрасов А. М. Возникновение и эволюция Крымского государства в XVXVI веках // Отечественная история. 1999. № 2. С. 48-57.

44. Новосельский А.А. Борьба Московского государства с татарами в первой половине XVII века. М.; Л.: Академия наук СССР, 1948. 447 с.

45. Одерборн Павел. Жизнь Иоанна Васильевича, великого князя Московии. Немецкий пастор Одерборн и его памфлет об Иване Грозном (1585) // Полосин И.И. Социально-политическая История России XVI - начала XVII в. М., 1963. С. 191-217.

46. Опись Царского архива XVI века и архив Посольского приказа 1614 года / Шмидт С.О. (ред.). М.: Восточная литература, 1960. 195 с.

47. Пенской В. В. Иван Грозный и Девлет-Гирей. М.: Вече, 2012. 320 с.

48. Полное собрание русских летописей, Т. III: Новгородская II летопись. СПб., $1841.308 \mathrm{c}$.

49. Полное собрание русских летописей, Т. ХІІІ: Никоновская летопись. Первая половина. СПб., 1904. 302 с.

50. Полное собрание русских летописей, Т. ХХ. Ч. 2: Львовская летопись. СПб., 1914. C. 419-686.

51. Полное собрание русских летописей, Т. XXIX: Летописец начала царства. M., $1965.390 \mathrm{c}$.

52. Полное собрание русских летописей, T. XXXIV: Московский летописец. М., $1978.304 \mathrm{c}$.

53. Послания Ивана Грозного. М.; Л.: Академия наук СССР, 1951. 715 с.

54. Посольская книга по связям Московского государства с Крымом. 1567-1572 гг. / Моисеев М.В (ред.). М.: Фонд «Русские Витязи», 2016. 400 с.

55. Посольская книга по связям Московского государства с Крымом. 1571-1577 гг. / Зайцев И.В. и др. (ред.). М.: Издательский дом Марджани, 2016. 400 с.

56. Посольские книги по связям России с Ногайской Ордой. 1489-1549 гг. Махачкала, $1995.355 \mathrm{c}$.

57. Посольские книги по связям России с Ногайской Ордой 1551-1561 гг. / Мустафина Д.А., Трепавлов В.В. (ред.). Казань, 2006. 391 с.

58. Разрядная книга. 1475-1598 гг. М., 1966. 614 с.

59. Разрядная книга. 1475-1605 гг., Т. 2. Ч. 1: 1566-1567 гг. М., 1981. 220 с.

60. Разрядная книга. 1475-1605 гг., Т. 2. Ч. 2: 1567-1577 гг. М., 1982. С. 221-440.

61. Разрядная книга. 1475-1605 гг., Т. 2. Ч. 3: 1577 г. М., 1982. С. 441-666.

62. Разрядная книга. 1550-1636 гг. М., 1975. Т. 1. 430 с.

63. Разрядная книга. 1559-1605 гг. М., 1974. 436 с.

64. Россия героическая. Рассказы русских летописей и воинские повести XIVXVI веков. М.: Молодая гвардия, 1988. 176 с.

65. Русская историческая песня: Сборник / Емельянов Л.И. (ред.). Л.: Сов. писатель, 1987. 544 с.

66. Сказания князя Курбскаго. Изд. 3-е / Устрялов Н. (ред.). СПб., 1868. 460 с.

67. «Скажите всем, что Русь всегда жива...»: Ратные дела Отечества: Русь и юная Россия. VI-XVI вв. / Золотарёв В.А. (ред.). М.: Издательский центр МАНПО; Animi Fortitudo, 2004. $616 \mathrm{c.}$

68. Скрынников Р.Г. Великий государь Иоанн Васильевич Грозный: в 2 т. Смоленск: Русич, 1996. Т. 2. 448 с.

69. Смирнов В.Д. Крымское ханство под верховенством Отоманской Порты до начала XVIII века. М.: Издательский дом «Рубежи XXI», 2005. T. 1. 541 с.

70. Список опричников Ивана Грозного. СПб.: Российская национальная библиотека, 2003. 152 с. 
71. Трепавлов В.В. История Ногайской Орды. М.: Восточная литература, 2001. $752 \mathrm{c}$.

72. Флетчер Дж. О государстве русском. М.: Захаров, 2002. 176 с.

73. Штаден Г. О Москве Ивана Грозного. Записки немца опричника. Л., 1925. $183 \mathrm{c}$.

74. Штаден Г. Записки о Московии: в 2 томах / Хорошкевич А.Л. (ред.). М.: Древлехранилище, 2009. Т. 2. 527 с.

75. Яковлев В.В. Ироничные «послания» Посольского приказа турецкому султану. (О семантике тюрко-монгольской титулатуры в русской дипломатической практике XVI-XVII вв.) // Тюркологический сборник, 2002. М.: Восточная литература, 2003. C. 401-415.

76. Inalcik H. The Khan and the tribal aristocracy: The Crimean Khanate under Sahib Giray I // Harvard Ukrainian Studies. Cambridge, Mass. 1980. Vol. 3/4. P. 445-466.

77. Tàrih-i Sàhib Giray Han (Histoire de Sahib Giray, khan de Crimée de 1532 à 1551) / Gökbîlgîn Ö. (ed. et tr.). Ankara, 1973. 313 s.

Сведения об авторе: Александр Геннадьевич Бахтин - доктор исторических наук, профессор кафедры общенаучных дисциплин и методики их преподавания Марийского государственного университета (424002, ул. Кремлевская, 44, Йошкар-Ола, Российская Федерация). E-mail: abachtin@mail.ru

Поступила 13.03.2021 Принята к публикации 20.05.2021

Опубликована 29.06.2021

\section{REFERENCES}

1. Abduzhemilev R.R. Remmal' Khodzha. Khronika "Tarikh-i Sakhib Gerey khan" ("Istoriya o khane Sakhib Geraye"). Ch. 1 [Remmal Khoja. The Chronicle "Tarkih-i Sahib Gerey Khan" ("History of Sahib Gerey Khan"). Part 1]. Krymskoye istoricheskoye obozreniye [Crimean Historical Review]. Kazan; Bakhchisaray, 2018, no. 1 (10), pp. 179195; Part 2, no. 2 (11), pp. 193-233. (In Russian)

2. Akchurin M.M. Administrativno-territorial'noye ustroystvo Meshchery XV nachala XVII vekov (Etnopoliticheskiye aspekty) [Administrative and Territorial Structure of Meshchera from the fifteenth to the beginning of the seventeenth century (Ethnopolitical aspects)]. Kazan, 2019. 257 p. (In Russian)

3. Andreyev A.R. Neizvestnoye Borodino. Molodinskaya bitva 1572 goda. Dokumental'naya khronika XVI veka [An Unknown Borodino. The Battle of Molodino in 1572. Documentary Chronicle of the sixteenth century]. Moscow: Interregional Center for Industry Informatics of Gosatomnadzor of Russia, 1997. 252 p. (In Russian)

4. Buganov V.I. Povest' o pobede nad krymskimi tatarami v 1572 godu [The story of the victory over the Crimean Tatars in 1572]. Arkheograficheskiy ezhegodnik za 1961 god. [Archaeographic Yearbook for 1961]. Moscow, 1962, pp. 259-275. (In Russian)

5. Burdey G.D. Molodinskaya bitva 1572 goda [The Battle of Molodino in 1572]. Iz istorii mezhslavyanskikh kul'turnykh svyazey. Uch. zap. in-ta slavyanovedeniya [From the History of Inter-Slavic Cultural Relations. Academic Notes of the Institute of Slavic Studies]. Moscow, 1963, vol. 26, pp. 48-79. (In Russian)

6. Veselovskiy S.B. Issledovaniya po istorii klassa sluzhilykh zemlevladel'tsev [Studies in the History of the Servant Landowner Class]. Moscow: Nauka, 1969. 583 p. (In Russian) 
7. Veselovskiy S.B. Onomastikon. Drevnerusskiye imena, prozvishcha i familii [Onomasticon. Old Russian Names, Nicknames, and Surnames]. Moscow: Nauka, 1974. 382 p. (In Russian)

8. Vinogradov A.V. Russko-krymskiye otnosheniya Smutnogo vremeni [RussianCrimean relations of the Time of Troubles]. Istoriya Kryma: $v 2 t$. [History of Crimea in Two Volumes] Moscow: Foundation "Link of the Epochs", 2017, vol. 1, pp. 406-417. (In Russian)

9. Vinogradov A.V. Russko-krymskiye otnosheniya 50-e - vtoraya polovina 70-kh godov XVI veka [Russian-Crimean Relations from the 1550s to second half of 1570s]. Moscow: Institute of Russian History of the Russian Academy of Sciences, 2007, vol. 1. 199 p. (In Russian)

10. Vinogradov A.V. Russko-krymskiye otnosheniya 50-e - vtoraya polovina 70-kh godov XVI veka [Russian-Crimean Relations from the 1550s to second half of 1570s]. Moscow: Institute of Russian History of the Russian Academy of Sciences, 2007, vol. 2. 342 p. (In Russian)

11. Vinogradov A.V. Russko-krymskiye otnosheniya v 1570-1590-kh gg. v kontekste dinasticheskogo krizisa Gireyev [Russian-Crimean relations from the 1570s to 1590s in the context of the Gireys' dynastic crisis]. Srednevekovyye tyurko-tatarskiye gosudarstva. Sb. st. [Medieval Turkic-Tatar States. Collected Papers]. Kazan, 2010, iss. 2, pp. 274-299. (In Russian)

12. Vinogradov A.V. Severnoye Prichernomor'ye v XVI v. v kontekste razvitiya mezhdunarodnykh otnosheniy v Vostochnoy Evrope [Northern Black Sea region in the sixteenth century in the context of the development of international relations in Eastern Europe]. Istoriya Novorossii: (Krym v istorii, kul'ture $i$ ekonomike Rossii) [History of Novorossiya: Crimea in the History, Culture, and Economy of Russia]. Zakharov V.N. (ed.). Moscow; St. Petersburg: Center for Humanitarian Initiatives, 2017, pp. 55-69. (In Russian)

13. Vinogradov A.V., Malov A.V. "Soshlis' s nimi u Voskresen'ya v Molodekh": Materialy o pokhode Devlet-Gireya I na Moskvu 1572 g. v Krymskoy posol'skoy knige 1571-1578 gg. ["We got together with them at Sunday in Molodino": Materials about the campaign of Devlet Girey I to Moscow in 1572 in the Crimean ambassadorial book for 1571-1578]. Edinorog": Materialy po voyennoy istorii Vostochnoy Evropy epokhi Srednikh vekov i Rannego Novogo vremeni [Unicorn: Materials on the Military History of Eastern Europe in the Middle Ages and Early Modern Times]. Moscow: Quadriga, 2011, iss. 2, pp. 202-253. (In Russian)

14. Volkov V.A. Voyny $i$ voyska Moskovskogo gosudarstva [Wars and Troops of the Muscovy]. Moscow: Esmo, Algorithm, 2004. 576 p. (In Russian)

15. Gabdullin I.R. Diveyevy [Diveyevs]. Tatarskaya entsiklopediya: $v 6$ t., T. II: $G-Y$ [Tatar Encyclopedia in Six Volumes, Vol. 2: G-Y]. Khasanov M.Kh. (ed.). Kazan: Institute of Tatar Encyclopedia, 2005, p. 282. (In Russian)

16. Heidenstein R. Zapiski o Moskovskoy voyne [Notes on the Moscow War]. St. Petersburg, 1889. 312 p. (In Russian)

17. Giray Khalim Sultan. Rozovyy kust khanov, ili istoriya Kryma = Gulbun-i hanan yahut Qirim tarihi: istoricheskaya literatura (Tekst) [The Rose Bush of the Khans, or the history of Crimea = Gulbun-i hanan yahut Qirim tarihi: Historical Literature (Text)]. Useinov K., Seytyagyayev N.S. (eds). Simferopol: "Dolya", 2004. 228 p. (In Russian)

18. Grushko E.A., Medvedev Yu.M. Slovar' familiy [Dictionary of Surnames]. Nizhny Novgorod: "Three heroes" and "Brothers Slavs", 1997. 592 p. (In Russian).

19. Gusev V.I. "Chtoby chuzhiye lyudi... bezvestno ne prikhodili" ["So that strangers ... do not come unknown"]. Voyenno-istoricheskiy zhurnal [Military History Journal]. Moscow, 1997, no. 5, pp. 76-81. (In Russian) 
20. Dokumenty Krymskogo khanstva iz sobraniya Khuseyna Feyzkhanova [Documents of the Crimean Khanate from the Collection of Husein Feyzkhanov]. Abduzhemilev R.R., Mirgaleev I.M. (eds). Simferopol: Constanta, 2017. 816 p. (In Russian)

21. Dudin A.A. Molodinskaya bitva [The Battle of Molodino]. Moscow: Scientific library, 2016. 130 p. (In Russian)

22. Erusalimskiy K.Yu. Na sluzhbe korolya i Rechi Pospolitoy [In the Service of the King and the Commonwealth]. Moscow; St. Petersburg: Nestor-History, 2018. 1012 p. (In Russian)

23. Zhirmunskiy V.M. Tyurkskiy geroicheskiy epos [Turkic Heroic Epic]. Leningrad: Nauka, 1974. 727 p. (In Russian)

24. Zaytsev I.V. Krymskaya istoriograficheskaya traditsiya XV-XIX vekov: puti razvitiya: rukopisi, teksty $i$ istochniki [Crimean Historiographic Tradition from the fifteenth to the nineteenth century: Ways of Development: Manuscripts, Texts, and Sources]. Moscow: Oriental literature, 2009. 304 p. (In Russian)

25. Zaytsev I.V. Mezhdu Moskvoy i Stambulom. Dzhuchidskiye gosudarstva, Moskva $i$ Osmanskaya imperiya (nach. XV-per. pol. XVI vv.). Ocherki [Between Moscow and Istanbul. Jochid States, Moscow, and the Ottoman Empire (from the early fifteenth to first half of sixteenth century). Essays]. Moscow, 2004. 216 p. (In Russian)

26. Ivanishchev N.D. Zhizn' knyazya Andreya Mikhaylovicha Kurbskogo v Litve i na Volyni [The Life of Prince Andrei Mikhailovich Kurbsky in Lithuania and Volhynia]. Kyiv, 1849, vol. 2. 364 p. (In Russian)

27. Iz knigi grodskoy Vladimirskoy 1577 goda / Sochineniya knyazya Kurbskogo, T. 1; Sochineniya original'nyye [From the Book of the City of Vladimir for 1577 / Works of Prince Kurbsky, Vol. 1: Original Works]. Russkaya istoricheskaya biblioteka, izdavayemaya Imperatorskoy Arkheograficheskoy komissiyey [Russian Historical Library Published by the Imperial Archaeographic Commission]. St. Petersburg, 1914, vol. 31, col. 513-564. (In Russian)

28. Istoricheskiye pesni. Ballady [Historical Songs. Ballads]. Azbelev S.N. (ed.). Moscow: "Contemporary", 1986. 622 p. (In Russian)

29. Istoriya o prikhode turetskago i tatarskago voinstva pod Astrakhan' v leto ot R. Kh. 1677 [The story of the arrival of the Turkish and Tatar armies near Astrakhan in 1677]. Zapiski Odesskago obshchestva istorii i drevnostey [Notes of the Odessa Society of History and Antiquities]. Odessa, 1872, vol. 8, pp. 479-488. (In Russian)

30. Karamzin N.M. Istoriya gosudarstva Rossiyskogo [History of the Russian State]. Kaluga: "Golden alley", 1995, vol. IX-XII. 592 p. (In Russian)

31. Kargalov V.V. Rus' i kochevniki [Rus' and the Nomads]. Moscow: Veche, 2004. 528 p. (In Russian).

32. Krom M.M. Sud'ba avantyurista: knyaz' Semen Fedorovich Bel'skiy [The fate of an adventurer: Prince Semyon Fedorovich Belsky]. Ocherki feodal'noy Rossii [Essays on Feudal Russia]. Moscow, 2000, iss. 4, pp. 98-115. (In Russian)

33. Kurbsky A. Istoriya o delakh velikogo knyazya moskovskogo [History of the Affairs of the Grand Duke of Moscow]. Rykov Yu.D. (ed.). Moscow: Nauka, 2015. 943 p. (In Russian)

34. Kurbsky A.M. Istoriya o velikom knyaze Moskovskom / Sochineniya knyazya Kurbskogo, T. 1: Sochineniya original'nyye [History of the Grand Duke of Moscow / The works of Prince Kurbsky, Vol. 1: Original writings]. Russkaya istoricheskaya biblioteka, izdavayemaya Imperatorskoy Arkheograficheskoy komissiyey [Russian Historical Library Published by the Imperial Archaeographic Commission]. St. Petersburg, 1914, vol. 31, pp. 161-354. (In Russian)

35. Lyzlov A.I. Skifskaya istoriya [Scythian History]. Moscow: Nauka, 1990. 519 p. (In Russian)

36. Malinovskiy A.F. Istoricheskoye i diplomaticheskoye sobraniye del, proiskhodivshikh mezhdu rossiyskimi velikimi knyaz'yami i byvshimi v Kryme tatarskimi tsaryami 
s 1462 po 1533 god, prilozheniye № 37 [Historical and diplomatic collection of affairs between the Russian Grand Dukes and the Tatar Tsars who were in Crimea from 1462 to 1533, Appendix No. 37]. Zapiski Odesskogo obshchestva istorii i drevnostey [Notes of the Odessa Society of History and Antiquities]. Odessa, 1863, vol. 5, pp. 178-419. (In Russian)

37. Maloizvestnyye letopisnyye pamyatniki XVI v. [Little-known chronicle monuments of the sixteenth century]. Tikhomirov M.N. Russkoye letopisaniye [Russian Chronicles]. Moscow: Nauka, 1979, pp. 220-229. (In Russian)

38. Miller V.F. Istoricheskiye pesni russkogo naroda XVI-XVII vv. [Historical Songs of the Russian People of the sixteenth and seventeenth century]. Petrograd: Printing house of the Imperial Academy of Sciences, 1915. 793 p. (In Russian)

39. Moiseev M.V. Kasimov, "Meshcherskiye mesta" v russko-nogayskikh otnosheniyakh XVI stoletiya [Kasimov: "Meschera places" in Russian-Nogai relations of the sixteenth century]. Tret'i Yakhontovskiye chteniya. Mat. nauchno-prakticheskoy konf. [The Third Yakhontov Readings. Proceedings of the Research and Practical Conference]. Ryazan, 2005, pp. 414-422. (In Russian)

40. Moiseev M. V. Shertnyye gramoty v kontekste russko-nogayskikh otnosheniy v XVI veke [Oath charters in the context of Russian-Nogai relations in the sixteenth century]. Srednevekovyye tyurko-tatarskiye gosudarstva [Medieval Turkic-Tatar States]. Kazan, 2014, no. 6, pp. 84-90. (In Russian)

41. Molodinskaya bitva [The battle of Molodino]. Slavyanskaya entsiklopediya. Kiyevskaya Rus' - Moskoviya: v 2 t. [Slavic Encyclopedia. Kyivan Rus' - Muscovy. In Two Volumes]. Moscow, 2005, vol. 1, pp. 745-746. (In Russian)

42. Mordovina S. P., Stanislavskiy A.L. Sostav osobogo dvora Ivana IV v period "velikogo knyazheniya" Simeona Bekbulatovicha [The composition of the special court of Ivan IV during the reign of the "Grand Duke" Simeon Bekbulatovich]. Arkheograficheskiy ezhegodnik za 1976 god [Archeografic Yearbook for 1976]. Moscow, 1977, pp. 153-191. (In Russian)

43. Nekrasov A.M. Vozniknoveniye i evolyutsiya Krymskogo gosudarstva v XV-XVI vekakh [The emergence and evolution of the Crimean state in the fifteenth and sixteenth centuries]. Otechestvennaya istoriya [Domestic History]. 1999, no. 2, pp. 48-57. (In Russian)

44. Novosel'skiy A.A. Bor'ba Moskovskogo gosudarstva s tatarami v pervoy polovine XVII veka [The Struggle of the Muscovite State with Tatars in the first half of seventeenth century]. Moscow; Leningrad: Publishing house of the USSR Academy of Sciences, 1948. 447 p. (In Russian)

45. Oderborn P. Zhizn' Ioanna Vasil'yevicha, velikogo knyazya Moskovii. Nemetskiy pastor Oderborn i ego pamflet ob Ivane Groznom (1585) [The life of Ioann Vasilievich, Grand Duke of Muscovy. German pastor Oderborn and his pamphlet about Ivan the Terrible (1585)]. Polosin I.I. Sotsial'no-politicheskaya Istoriya Rossii XVI - nachala XVII v. [Socio-political History of Russia in the sixteenth and early seventeenth century]. Moscow, 1963, pp. 191-217. (In Russian)

46. Opis' Tsarskogo arkhiva XVI veka i arkhiv Posol'skogo prikaza 1614 goda [Inventory of the Tsar's Archive of the sixteenth century and the Archive of the Ambassadorial Office of 1614]. Schmidt S.O. (ed.). Moscow: "Oriental literature", 1960. 195 p. (In Russian)

47. Penskoy V.V. Ivan Groznyy i Devlet-Girey [Ivan the Terrible and Devlet Girey]. Moscow: Veche, 2012. 320 p. (In Russian)

48. Polnoye sobraniye russkikh letopisey: Novgorodskaya II letopis' [Complete Collection of Russian Chronicles, Vol. 3: Novgorod Second Chronicle]. St. Petersburg, 1841. 308 p. (In Russian)

49. Polnoye sobraniye russkikh letopisey: Nikonovskaya letopis'. Pervaya polovina [Complete Collection of Russian Chronicles, Vol. 13: Nikon Chronicle. The First Half]. St. Petersburg, 1904. 302 p. (In Russian) 
50. Polnoye sobraniye russkikh letopisey: L'vovskaya letopis' [Complete Collection of Russian Chronicles, Vol. 22. Part 2: Lvov Chronicle]. St. Petersburg, 1914, pp. 419-686. (In Russian)

51. Polnoye sobraniye russkikh letopisey: Letopisets nachala tsarstva [Complete Collection of Russian Chronicles, Vol. 30: Chronicle of the Beginning of Tsardom]. Moscow, 1965. 390 p. (In Russian)

52. Polnoye sobraniye russkikh letopisey: Moskovskiy letopisets [Complete Collection of Russian Chronicles, Vol. 34: Moscow Chronicle]. Moscow, 1978. 304 p. (In Russian)

53. Poslaniya Ivana Groznogo [Letters of Ivan the Terrible]. Moscow; Leningrad: Publishing house of the USSR Academy of Sciences, 1951. 715 p. (In Russian)

54. Posol'skaya kniga po svyazyam Moskovskogo gosudarstva s Krymom. 1567$1572 \mathrm{gg}$. [Ambassadorial Book on the Relations of the Muscovite State with Crimea. 15671572]. Moiseev M.V. (ed.). Moscow: "Russian Knights" foundation, 2016. 400 p. (In Russian)

55. Posol'skaya kniga po svyazyam Moskovskogo gosudarstva s Krymom. 1571-1577 gg. [Ambassadorial Book on the Relations of the Muscovite State with Crimea. 1571-1577] Zaytsev I.V. et al. (eds). Moscow: Marjani publishing house, 2016. 400 p. (In Russian)

56. Posol'skiye knigi po svyazyam Rossii s Nogayskoy Ordoy. 1489-1549 gg. [Ambassadorial Books on Russia's Relations with the Nogai Horde. 1489-1549]. Makhachkala, 1995. 355 p. (In Russian)

57. Posol'skiye knigi po svyazyam Rossii s Nogayskoy Ordoy 1551-1561 gg. [Ambassadorial Books on Russia's Relations with the Nogai Horde. 1551-1561]. Mustafina D.A., Trepavlov V.V. (eds). Kazan, 2006. 391 p. (In Russian)

58. Razryadnaya kniga. 1475-1598 gg. [Razriad Book. 1475-1598]. Moscow, 1966. 614 p. (In Russian)

59. Razryadnaya kniga. 1475-1605 gg. [Razriad Book. 1475-1605, Vol. 2. Part 1: 1566-1567]. Moscow, 1981. 220 p. (In Russian)

60. Razryadnaya kniga. 1475-1605 gg. [Razriad Book. 1475-1605, Vol. 2. Part 2: 1567-1577]. Moscow, 1982, pp. 221-440. (In Russian)

61. Razryadnaya kniga. 1475-1605 gg. [Razriad Book. 1475-1605, Vol. 2. Part 3: 1577]. Moscow, 1982, pp. 441-666. (In Russian)

62. Razryadnaya kniga. 1550-1636 gg. [Razriad Book. 1550-1636]. Moscow, 1975, vol. 1.430 p. (In Russian)

63. Razryadnaya kniga. 1559-1605 gg. [Razriad Book. 1559-1605]. Moscow, 1974. 436 p. (In Russian)

64. Rossiya geroicheskaya. Rasskazy russkikh letopisey $i$ voinskiye povesti XIV-XVI vekov [Heroic Russia. Stories of Russian Chronicles and Military Tales from the fourteenth to sixteenth century]. Moscow: Young guard, 1988. 176 p. (In Russian).

65. Russkaya istoricheskaya pesnya: Sbornik [Russian Historical Song: Collection]. Emel'yanov L.I. (ed.). Leningrad: Soviet writer, 1987. 544 p. (In Russian).

66. Skazaniya knyazya Kurbskago [Tales of Prince Kurbsky]. Third edition. Ustryalov N. (ed.). St. Petersburg, 1868. 460 p. (In Russian)

67. "Skazhite vsem, chto Rus' vsegda zhiva...": Ratnyye dela Otechestva: Rus' $i$ yunaya Rossiya. VI-XVI vv. ["Tell everyone that Russia is always alive ...": Warfare of the Fatherland: Russia and Young Russia. From the sixth to sixteenth century]. Zolotarev V.A. (ed.). Moscow: MANPO publishing centre; "Animi Fortitudo", 2004. 616 p. (In Russian).

68. Skrynnikov R.G. Velikiy gosudar' Ioann Vasil'yevich Groznyy: v 2 t. [Great Emperor Ioann Vasilievich the Terrible: In Two Volumes]. Smolensk: Rusich, 1996, vol. 2. 448 p. (In Russian).

69. Smirnov V.D. Krymskoye khanstvo pod verkhovenstvom Otomanskoy Porty do nachala XVIII veka [Crimean Khanate under the Rule of the Ottoman Port until the beginning of eighteenth century]. Moscow: Milestones XXI publishing house, 2005, vol. 1. 541 p. (In Russian). 
70. Spisok oprichnikov Ivana Groznogo [List of Ivan the Terrible's Oprichniki]. St. Petersburg: Russian National Library, 2003. 152 p. (In Russian)

71. Trepavlov V.V. Istoriya Nogayskoy Ordy [History of the Nogai Horde]. Moscow: Oriental literature, 2001. 752 p. (In Russian)

72. Fletcher J. O gosudarstve russkom [On the Russian State]. Moscow: Zakharov, 2002. 176 p. (In Russian)

73. Staden G. O Moskve Ivana Groznogo. Zapiski nemtsa oprichnika [About Moscow of Ivan the Terrible. Notes of the German Oprichnik]. Leningrad, 1925. 183 p. (In Russian)

74. Staden G. Zapiski o Moskovii: v 2 tomakh [Notes on the Muscovy: In Two Volumes]. Khoroshkevich A.L. (ed.). Moscow: Archives, 2009, vol. 2. 527 p. (In Russian)

75. Yakovlev V.V. Ironichnyye "poslaniya" Posol'skogo prikaza turetskomu sultanu. (O semantike tyurko-mongol'skoy titulatury $\mathrm{v}$ russkoy diplomaticheskoy praktike XVIXVII vv.) [Ironic "messages" of the Ambassadorial office to the Turkish sultan (On the semantics of the Turkic-Mongol titulature in the Russian diplomatic practice of the sixteenth and seventeenth century)]. Tyurkologicheskiy sbornik, 2002 [Turkological Collection, 2002]. Moscow: Oriental literature, 2003, pp. 401-415. (In Russian)

76. Inalcik $\mathrm{H}$. The Khan and the tribal aristocracy: The Crimean Khanate under Sahib Giray I. Harvard Ukrainian Studies. Cambridge, Mass. 1980, vol. 3/4, pp. 445-466.

77. Tàrih-i Sàhib Giray Han. (Histoire de Sahib Giray, khan de Crimée de 1532 à 1551). Gökbîlgîn Ö. (ed. et tr.). Ankara, 1973. 313 p. (In Turkish and French)

About the author: Alexander G. Bakhtin - Dr. Sci. (History), Professor of the Department of General Scientific Disciplines and Methods of Their Teaching of the Mari State University (44, Kremlevskaya Str., Yoshkar-Ola 424002, Russian Federation)

Received March 13, 2021 Accepted for publication May 20, 2021

Published June 29, 2021 


\title{
ХАНСКИЙ УКАЗ О НАЗНАЧЕНИИ МУФТИЯ: МУСУЛЬМАНЕ ПОД ВЛАСТЬЮ ВОЛЖСКИХ КАЛМЫКОВ
}

\author{
И.А. Мустакимов ${ }^{1,2}$, Г.М. Ханнанова ${ }^{3}$ \\ ${ }^{1}$ Казанский федеральный университет \\ Казань, Российская Федерация \\ ${ }^{2}$ Национальная библиотека Республики Татарстан \\ Казань, Российская Федерация \\ imus2007@mail.ru \\ ${ }^{3}$ Институт языка, литературы и искусства им. Г. Ибрагимова \\ Академии наук Республики Татарстан \\ Казань, Российская Федерация \\ ghan2003@mail.ru
}

Цель исследования: введение в научный оборот и предварительное исследование указа калмыцкого правителя Дондук-Даши-хана (правил в 1741-1761 гг.) о пожаловании некоему Мустафе-хаджи должности муфтия подвластных Дондук-Даши мусульман, а также должности казия и зайсанга ногаев.

Материаль исследования: указ, датированный 1750 годом, дошел до нас в копии XIX в., отложившейся в личном архиве татарского религиозного деятеля и просветителя конца XIX - начала XX в. Абдурахмана Умерова. В исследовании также используются картографические и лексикографические источники, привлекаются работы по тюркской и монгольской дипломатике.

Результаты и научная новизна исследования: В настоящее время правовой статус представителей тюрко-мусульманских подданных калмыцких правителей, методы управления ими изучены недостаточно. Во многом это обусловлено малочисленностью документальных источников, введенных в научный оборот. Публикация указа Дондук-Даши-хана в определенной степени восполняет пробел в наших знаниях о названной проблеме.

Ключевые слова: калмыки, ногаи, алабугатские татары, Дондук-Даши-хан, калмыцкая (монгольская) и тюрко-татарская дипломатика

Для цитирования: Мустакимов И.А., Ханнанова Г.М. Ханский указ о назначении муфтия: мусульмане под властью волжских калмыков // Золотоордынское обозрение. 2021. T. 9, № 2. С. 423-437. DOI: 10.22378/2313-6197.2021-9-2.423-437 


\title{
KHAN'S DECREE ON THE APPOINTMENT OF THE MUFTI: MUSLIMS UNDER THE RULE OF THE VOLGA KALMYKS
}

\author{
I.A. Mustakimov ${ }^{1,2}$, G.M. Khannanova ${ }^{3}$ \\ ${ }^{1}$ Kazan Federal University \\ Kazan, Russian Federation \\ ${ }^{2}$ National Library of the Republic of Tatarstan \\ Kazan, Russian Federation \\ imus2007@mail.ru \\ ${ }^{3}$ G.Ibragimov Institute of Language, Literature and Art \\ of Tatarstan Academy of Sciences \\ Kazan, Russian Federation \\ ghan2003@mail.ru
}

\begin{abstract}
Research objectives: This article is dedicated to preliminarily research and the publication of the decree of the Kalmyk ruler, Donduk-Dashi Khan (r. 1741-1761), assigning to Mustafa Hajji the position of the mufti of the Muslims - people which were dependent on Donduk-Dashi Khan - as well as the position of the qadi and zaisang of the Nogays.

Research materials: The decree (dated to 1750) reached us as a copy from the nineteenth century which was kept in the private archives of Abd al-Rahman Umerov - the Tatar religious leader and enlightener who was active at the end of nineteenth and beginning of twentieth century. Cartographic and lexicographic sources were used as well as works on Turkic and Mongolian diplomacy.

Results and novelty of the research: The legal status of the representatives of TurkicMuslim subjects of the Kalmyk rulers and the methods of their administration were not studied sufficiently up to the present. This is a result of the small number of the documentary sources which have been thus far introduced into scholarly circles. The publication of this decree of Donduk-Dashi Khan will fill the gaps in our knowledge of this problem.
\end{abstract}

Keywords: Kalmyks, Nogays, Alabugat Tatars, Donduk-Dashi Khan, Kalmyk (Mongol) and Turkic-Tatar diplomatics

For citation: Mustakimov I.A., Khannanova G.M. Khan's Decree on the Appointment of the Mufti: Muslims under the Rule of the Volga Kalmyks. Zolotoordynskoe obozrenie $=$ Golden Horde Review. 2021, vol. 9, no. 2, pp. 423-437. DOI: 10.22378/23136197.2021-9-2.423-437

Процессы, происходившие в Центральной Азии в XVI - начале XVII вв., привели к миграции части ойратских племен на запад, в основном на территорию бывшего улуса Джучи: к началу XVII в. западные ойраты расселились в Западном и Центральном Казахстане и вышли к Яику и Волге [26, с. 411413]. В течение первой половины XVII в. под контроль калмыцких предводителей перешли территории, ранее принадлежавшие Большой Ногайской Орде. Ойратская миграция сопровождалась вытеснением или подчинением наследников Золотой Орды - ногаев и казахов и завоеванием части туркмен [26, с. $415,429,448 ; 24$, с. 45, 165, примеч. 2 к док. № 27]. Время от времени в калмыцких владениях укрывались мятежные башкиры [21; 23, с. 555-558] и обретались татары [25, с. 51].

Свою экспансию, а позже власть над тюркскими наследниками Золотой Орды, калмыки обосновывали своей принадлежностью к потомкам и наслед- 
никам Чингис-хана [18, с. 34; 19, с. 264]. Как и первым монгольским ханамчингисидам, калмыцким правителям при осуществлении управления своими подданными приходилось учитывать наличие среди них большой доли иноэтничного и иноконфессионального населения. Известно, что по крайней мере в начале XVIII в. в Калмыцком ханстве существовала должность «главы мусульман». Так, в турецком переводе послания калмыцкого правителя Аюки османскому султану, датируемом 1703-1704 гг., в качестве главы доставившего эту грамоту калмыцкого посольства назван «глава (ага) мусульман нашей страны... Иш-Мухаммед-ага» [9, с. 253].

До наших дней дошло мало документальных источников, созданных в калмыцких канцеляриях, которые содержали бы подробные сведения о положении тюрко-мусульманского населения в составе Калмыцкого ханства в XVII-XVIII вв. Одним из них является копия или тюркский перевод жалованной грамоты калмыцкого правителя Дондук-Даши (правил в 1741-1761 гг.) некоему Мустафе-хаджи (ниже в тексте документа он упоминается просто как «Хаджи»). Этот документ сохранился в составе личного архива астраханского религиозного деятеля и просветителя конца XIX - начала XX в. Абдурахмана Умерова $^{1}$, составившего фонд Р-5406 Государственного архива Республики Татарстан.

Документ написан на половине листа довольно плотной нелощеной бумаги едва заметного зеленоватого оттенка размером $34 \times 22,5$ см, содержит следы реставрации, по-видимому, конца XIX в. или первой половины XX в. (сгибы подклеены кусочками бумаги). Лист имеет водяные знаки «СА», что позволяет датировать бумагу 1831 годом [17, с. 62, № 555]. Таким образом, документ написан не ранее 1831 г., но не позднее середины XIX столетия. Рукопись выполнена темно-коричневыми чернилами, широко применявшимися в обиходе мусульманского населения Волго-Уральского региона XVII-XIX вв. Почерк документа условно можно определить как насх с элементами таалика. Размер текста 15,5×15,5 см, высота букв по алифу - 0,3-0,4 см.

В фонде А. Умерова также имеется черно-белая фотокопия данного документа ${ }^{2}$. Кроме того, две черно-белые фотокопии этого же документа отложились в восточном секторе отдела рукописей и редких книг Научной библиотеки им. Н.И. Лобачевского ${ }^{3}$. Как следует из вложенной в дело записки, выполненной по-татарски на арабице, очевидно, сыном Абдурахмана Умерова - Абдулхамидом Умеровым - в 1975 г., эти фотокопии были переданы в вышеуказанную библиотеку ${ }^{4}$.

\footnotetext{
${ }^{1}$ См. о нем: [7].
}

${ }^{2}$ Государственный архив Республики Татарстан, ф. Р-5406, оп. 1, д. 44, л. 35.

${ }^{3}$ Отдел рукописей и редких книг Научной библиотеки им. Н.И. Лобачевского Казанского (Приволжского) федерального университета, ед. хр. 3262т.

${ }^{4}$ Вот полный текст записки, приложенной к фотокопиям: «18 нче гасыр урталарында Әстерхан тирәсендәге нугайларда кулланылган рәсми идарә теленең бер үрнәге. Әстерхан даласындагы Калмык ханлыгының башы булган Дундук Дашы ханның үз кул астында яшәүче нугай халкына Мостафа хажи дигән кешене казый һәм зайсаң итеп билгеләве турында 1749 нчы елда биргән фәрманының калмыкчадан төркичәгә шул вакытта ясалган тәржемәсе. Фотокүчермә. Тапшыручы: Габделхәмид Гомәрев. 9.VI.1975» («Образец официального языка [государственного] управления, использовавшегося у ногаев, [обретавшихся] около Астрахани в середине XVIII века. Перевод с калмыцкого на тюркский язык указа правителя Калмыцкого ханства в Астраханской степи Дондук- 
Имеющиеся данные и упомянутые в документе реалии не дают оснований сомневаться в существовании его протографа, составленного в середине XVIII в.

Учитывая довольно развитое делопроизводство на калмыцком языке [24, c. 15-17, 30], можно предполагать, что подлинник указа был написан покалмыцки и тогда же переведен на тюркский язык, чтобы быть понятнее мусульманским подданным Дондук-Даши 5 . Широкое бытование тюркского языка во владениях калмыцких правителей находит подтверждение и в калмыцких документах 6 .

Текст указа составлен весьма грамотно. Фонетическая структура языка и лексика документа близка к таковой современного ногайского языка и языка алабугатских татар. В части фонетики это выражается во встречающемся пере-

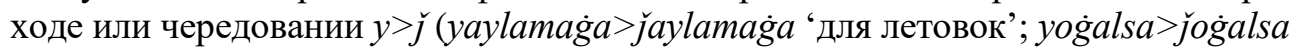
'если пропадет'; yürmäsün jürmäsün 'пусть не кочует'), в чередовании $\check{c} \sim \check{s}$ (čiqsa 'если появится', но šapsun [вместо čapsun] 'пусть карает’ [букв. 'пусть рубит']). В лексике ногайский и алабугатский элемент выражается в личном местоимении maga 'мне' [1; 4]. Калмыцкий лексический элемент представлен словами зайсаң 'зайсанг', darag்a 'секретарь; порученец', јиwïq 'вор' (соврем. калм. жсуук ‘пройдоха, жулик; мошенник’ [16, с. 233]).

Очевидно языковые особенности документа отражают разговорную речь кочевого тюркского (в своей основе ногайского) населения Калмыцкого ханства. Лишь несколько раз встречаются элементы османско-турецкой лексики (kändi älim вм. öz qolïm 'своя рука', титул ӓfändi 'господин' ${ }^{\text {,7 }}$ и морфологии (olan вм. bolgan 'находящийся', muțī' ola вм. muț̄' bolgay или muț̄' bolsïn 'да повинуются! ${ }^{8}$ ). Возможно, эти особенности обусловлены влиянием литературного языка и канцелярского стиля Крымского ханства, с конца XV в. находившихся под все усиливающимся влиянием османско-турецкого языка. В тексте грамоты сравнительно немного арабских и персидских заимствований. Среди них следует особо упомянуть мусульманское богословие Hüwä (араб. 'Он', т.е. Бог) - обычный атрибут начального протокола официальных и частных бумаг в странах ислама, несвойственный монгольским и калмыцким актам. По-видимому, это слово было введено мусульманином-переводчиком документа. Обращает на себя внимание, что формуляр и стилистика указа Дондук-Даши существенно отличается как от аналогичных джучидских грамот XIV-XVI вв. [27], так и от почти современных ему жалованной грамоты восточномонгольского (халхаского) правителя Шестого Далай-Сецен-хана, датируемой 1725 г. [10], и указа калмыцкого хана Убаши 1766 г. [32, p. 5-8]. Другие, аналогичные публикуемому, указы калмыцких правителей нам неиз-

Даши-хана, изданного в 1749 году, о назначении человека по имени Мустафа-хаджи кадием и зайсангом подвластных ему (Дондук-Даши-хану. - И.М., Г.Х.) ногаев, сделанный в то время. Фотокопия. Передал: Абдулхамид Умеров. 9.VI.1975»).

${ }^{5}$ Такое же мнение было высказано Абдулхамидом Умеровым (см. примеч. 4).

${ }^{6}$ В одном из писем Аюки-хана астраханскому обер-коменданту М.И. Чирикову просьба посылать в ханскую ставку русского гонца по имени Михаил обосновывается тем, что он «знает татарский (в ориг. мангhyд 'ногайский') язык» [24, с. 100]. См. также: $[28$, c. 69$]$.

${ }^{7}$ В XIX в. (очевидно, и ранее) термин «эфенди» у ногайцев обозначал духовное лицо [14, c. 148].

${ }^{8}$ Букв. «да повинуется!». 
вестны (не исключено, что они отложились в древлехранилищах Москвы, Санкт-Петербурга, Астрахани, Элисты или других городов).

Понимание текста грамоты усложняется наличием неизвестных терминов и топонимов. Нам не удалось найти сведения о держателе грамоты Мустафехаджи, упомянутом в тексте его отце Кышлау-эфенди, а также идентифицировать некоторые географические объекты, перечисленные в документе.

Исходя из упоминания о проезде через кочевья подданных Мустафыхаджи «в Крым, на Кубань, в Кабарду [и] Кизляр», можно заключить, что кочевья подвластных Мустафе-хаджи ногаев находились между Волгой и северокавказскими областями, близ каспийского побережья. Упоминание в документе топонима الابوغاط بوغطى (الابوغاط بوغظى (читаем 《Алабугатское устье», «Алабугатский рукав», «Алабугатский пролив» позволяет предполагать его связь с озером Алабуга, обозначенным на составленной в 1864 г. «Карте Калмыцкой степи Астраханской губернии с обозначением хозяйственного распределения земель» И. Крыжина под $45^{\circ} 20^{\prime}$ северной широты и $16^{\circ} 30^{\prime}$ восточной долготы [15, вклейка]. Это же озеро под названием Алабугат зафиксировано на карте Большой и Малой Кабарды 1744 г., составленной геодезистом С. Чичаговым, на $46^{\circ}$ северной широты и $66^{\circ}$ восточной долготы [13, вклейка между с. 114 и 115]. В изданном годом позднее «Атласе Российском...» оно обозначено как «оз[еро] соленое Лабуга» и зафиксировано между $45^{\circ}$ и $46^{\circ}$ северной широты и около $67^{\circ}$ восточной долготы [3, карта № 11 ]. Кажется, этот же топоним упомянут в донесении русского посланника в ногайские улусы Ф. Елагина (1640 г.), отметившего кочевание 3 ногайских мирз с 3 тысячами человек по «Елабуге» и к Кумскому кутлуку [22, с. 285]. Еще один топоним - الاغان ترنك - без труда отождествляется с озером Алагантернек, зафиксированным на карте С. Чичагова севернее озера Алабугат [13, вклейка между с. 114 и 115]. В «Атласе Российском...» этот географический объект обозначен как «оз[еро] Алаган Терник соленой» и зафиксирован также севернее озера Алабуга Алабугат Лабуга [3, карта № 11]. Очевидно, с этим озером связано название исчезнувшего села Алабуга и экзоэтноним алабугатские татары (ногайцы) / утары-алабугатцы ${ }^{9}$.

В публикуемом указе отразилось законоположение, введенное ДондукДаши-ханом, о необходимости извещать «знатных людей» или ханских чиновников обо всех проезжающих и приезжих (строки 4-5, 14-15) (во избежание похищений скота) [8, с. 65-66].

Отдельного упоминания заслуживает датировка документа. Для обозначения года в нем использован распространенный у народов Восточной и Центральной Азии циклический животный календарь. День и месяц составления указа обозначены по монгольской традиции. Что касается пометы в документе, то она, по-видимому, принадлежит татарскому переписчику, не очень хорошо знакомому с животным календарем, вовсе незнакомому с системой счета месяцев у монгольских народов, однако хорошо знакомому с порядком современного ему русского летосчисления. Поэтому дата «семнадцатый день первого осеннего месяца года лошади» была понята им как 17 сентября 1749 г., тогда как, согласно использовавшемуся калмыками восточноазиатскому лунно-

\footnotetext{
${ }^{9}$ Об этой этнографической группе см.: [1; 2, с. 348-350; 5, с. 529-530].
} 
солнечному календарю, она соответствует 18 августа 1750 г. григорианского летосчисления [29, с. 334] (7 августа 1750 г. по юлианскому календарю).

Вызывает некоторые сомнения правомерность использования ДондукДаши ханского титула: до 1757 г. этот правитель в русских документах носил звание наместника ханства калмыцкого, и лишь в 1757 г. русским правительством ему был пожалован ханский титул [6, с. 261; 8, с. 131]. Не было у него инвеституры на ханство и от Далай-ламы [30, с. 1058]. Вопрос, мог ли при этом Дондук-Даши в калмыцких и тюркоязычных актах, касающихся внутренних дел Калмыцкого ханства, титуловаться ханом, либо ханский титул в публикуемый список документа вставлен позднейшим переписчиком, остается открытым. Явно намеренный вынос слова «хан» над строкой в интитуляции указа (строка 2), и его повторное использование в конце документа (строка 19), кажется, говорит в пользу первой версии.

Ниже приводятся факсимиле, наборный текст документа на арабской графике и его перевод на русский язык. Начало строки в наборном тексте и переводе отмечено арабской цифрой в круглых скобках. В переводе в квадратные скобки заключены слова, подразумеваемые по контексту.

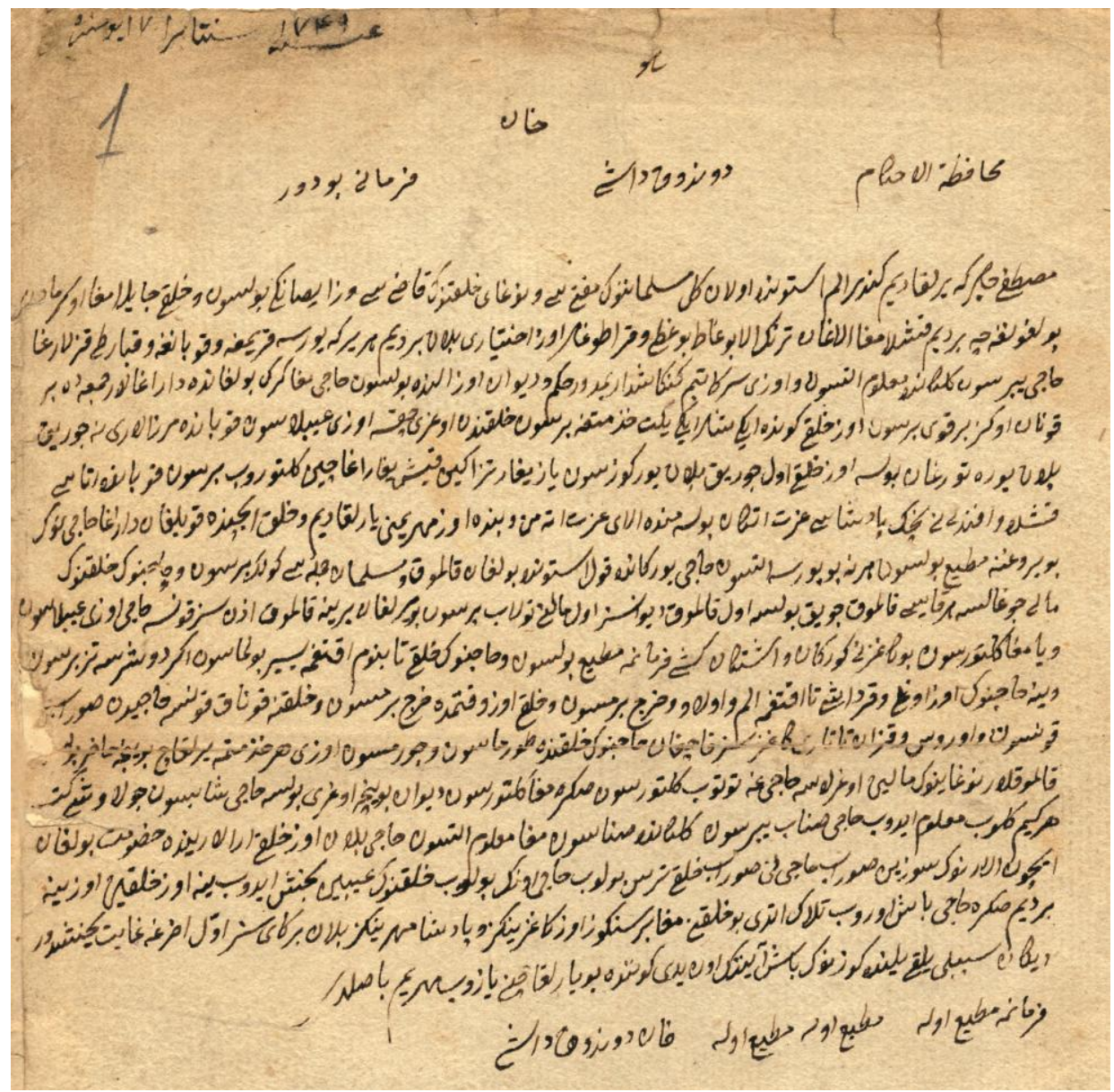

ГА РТ, ф. P-5406, оn. 1, д. 51, л. 1. Копия XIX 8. 


\section{Указ калмыцкого правителя Дондук-Даши-хана о пожаловании Мустафе-хаджи должности муфтия подвластных хану мусульман, а также казия и зайсанга ногаев}

18 августа 1750 2.

$$
\text { محافظة الاحكام دوندوق داشى خان } 10 \text { فر مانى بودور }
$$

(3) مصطفى حاجى كه يرلقاديم كندى الم استونده اولان كل مسلماننوك مفتى سى و نوغاى خلقنوك قاضى سى و زايصانكى بولسون و خلقى جايلامغا اوكرمادن (4) بولغونغه جه برديم

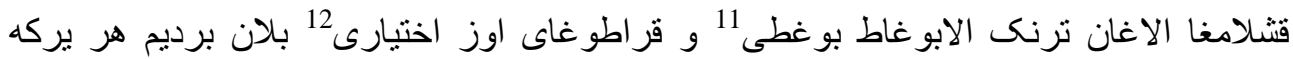

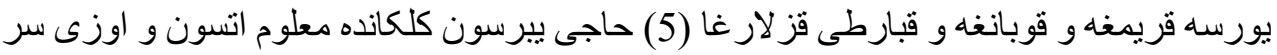

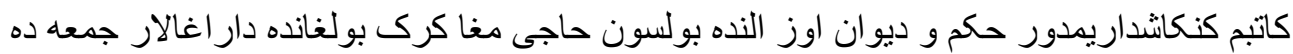
بر (6) قونان اوكز بر قوى برسون اوز خلقى كونده *|يكى شاى 13 ايكى يكت خذمتغه برسون

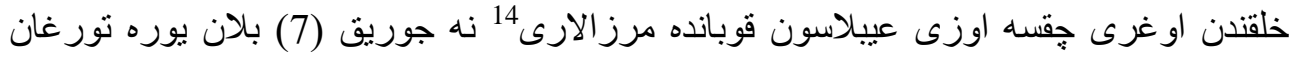

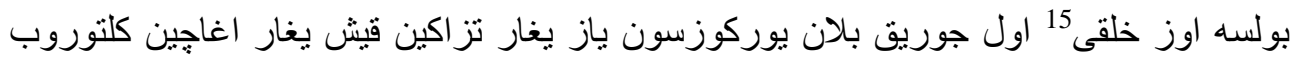

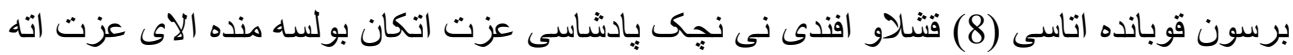

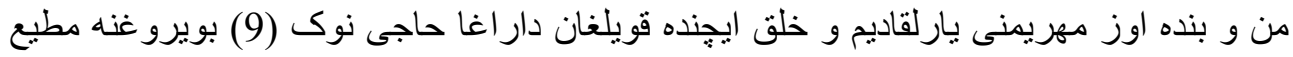
بولسون هر نه بويورسه اتسون حاجى يوركانده قول استونده بولغان قالموق و مسلمان جمله سى بـى لون كولك برسون و حاجنوى خلقنوى (10) مالى جوغالسه هر قايسى قالموق جويق بولسه اول

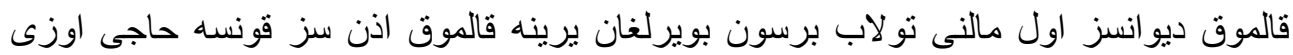

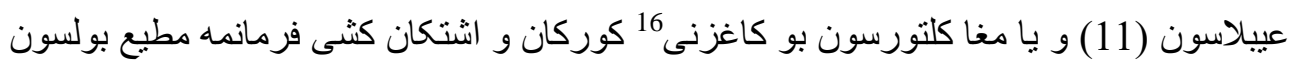
و حاجنوك خلقى تا بنوم اقتغمه يسير بولماسون اكر دوشرسه تز برسون (12) و ينه حاجنوك اوز

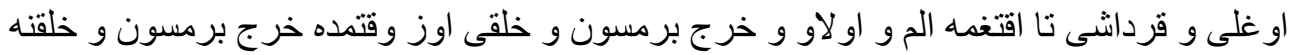

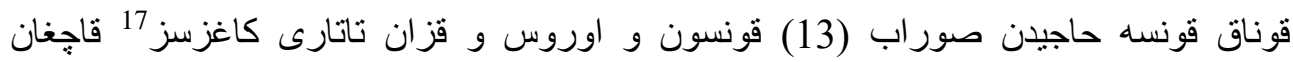

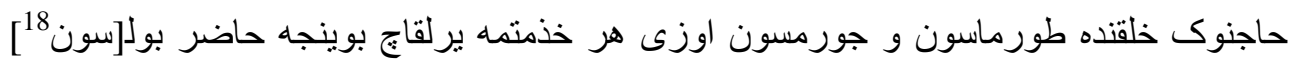
(14) قالموقلار نوغاينوك مالين اوغرلاسه حاجى غه نونوب كلتورسون صكره مغا كلتورسون ديوان بوينجه اوغرى بولسه حاجى شابسون جولاوشى كتسه (15) هر كيم كلوب معلوم ايدوب حاجى صناب يبرسون كلكانده صناسون مغا معلوم اتسون حاجى بلان اوز خلقى ارونى ار الارينده

\footnotetext{
${ }^{10}$ Слово خان вынесено над строкой.

${ }^{11}$ Recto بو غظى (?)

12 Recto اختياريم

* ايكى شار Recto (?)

ميرز الارى مئم

15 Recto خلقين

${ }^{16}$ Recto كاغذنى

${ }^{17}$ Recto كاغذنز

${ }^{18}$ Фрагмент, заключенный в квадратные скобки, в документе утрачен.
} 


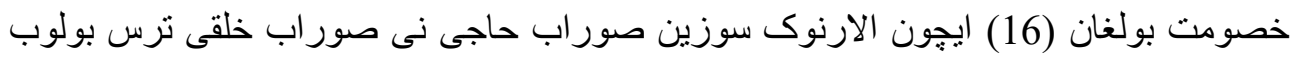

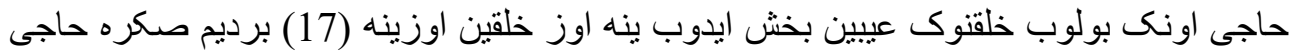

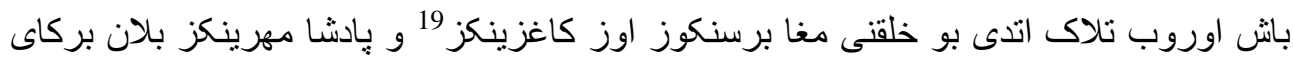

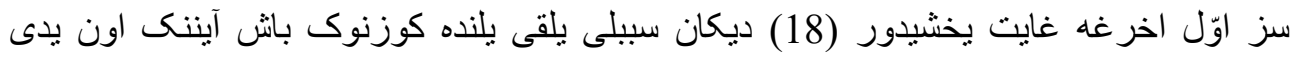

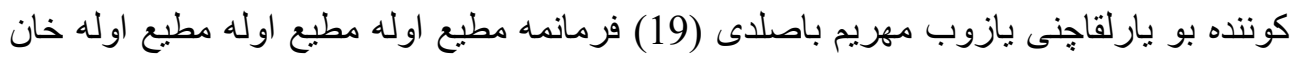

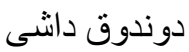

В верхней левой части листа той же рукой помета:

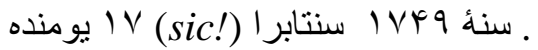

ГА РТ, ф. P-5406, on. 1, д. 51, л. 1. Копия XIX в.

\section{ПЕРЕВОД}

(1) $\mathrm{OH} !^{20}$

(2) Сие есть указ обладателя власти Дондук-Даши-хана

(3) Пожаловал я Мустафу-хаджи, дабы был он муфтием ${ }^{21}$ всех подвластных мне мусульман, а также казием ${ }^{22}$ и зайсангом ${ }^{23}$ ногайского народа. Своею волей дал его народу для летних кочевий [земли] от Угерме (4) до Булгуна, для зимних кочевий - Алаган-Тернек, *Алабугатское устье ${ }^{24}$ и КараТогай. [Кто бы] куда бы ни поехал - в Крым, на Кубань, в *Кабарду [и] Кизляр $(?)^{25}(5)$ - пусть Хаджи пропускает, когда [кто-либо] прибывает - пусть ставит в известность. Он же является моим [личным] секретарем (sirr kätibim) [и] советником (keךäšdārïm). Пусть суд и расправа [над его людьми] будут в его собственных руках. Когда мне понадобится, пусть дает мне дараг ${ }^{26}$, пусть

${ }^{19}$ Recto كاغذينكز

${ }^{20}$ T.е. Бог.

${ }^{21}$ Муфтий - мусульманский законовед, имеющий право издавать фетвы (решения по различным вопросам мусульманского вероучения).

${ }^{22}$ Казий (кадий) - мусульманский судья, отправляющий правосудие по законам шариата.

23 Зайсанг - родовой наследственный старшина у монголов и калмыков. Крымский хронист XVIII в. Абдулгаффар Кырыми термин «зайсанг» переводит как «великий князь» $(\ddot{a} m \bar{\imath} r-i k a ̈ b i r)$ [31, s. 18]. Российский чиновник XVIII в. Т.Г. Масленицкий именует зайсангов «дворянами» и отмечает, что они предводительствуют аймаками - группами населения, составляющими улус - владения каждого калмыцкого князя-нойона [20, с. 476]. См. также: [11, с. 7].

*24 الابو غاط بو غطى (الابو غاط بو غظى (читаю). Возможные переводы: «Алабугатский рукав»; «Алабугатский пролив».

*25 قبارطى قز لارغا. Возможно, имеется в виду Казыева Кабарда (قبارطى قازى) [33, p. 59; 12, passim].

26 Дарага (или дарга) - управляющий князя [8, с. 109]; секретарь, делопроизводитель или курьер, отправленный за делом от одного улуса к другому или в российские города и 
еженедельно дает одного (6) вола-двухлетку, одну овцу. Пусть его народ ежедневно дает [мне] на службу *дважды по два добрых молодца ${ }^{27}$. Если из его народа сыщется вор, пусть судит его сам. *[Во время кочевания] пусть водит свой народ тем же путем, (7) что и кубанские мирзы ${ }^{28}$. Летом на топливо пусть поставляет кизяк, зимой - дрова. Как его государь [крымский хан?] дорожил его отцом Кышлау-эфенди (8) на Кубани, так и я дорожу им, и я равным образом пожаловал ему свою печать ${ }^{29}$. И пусть назначенный над народом дарага ${ }^{30}$ повинуется (9) приказам Хаджи; пусть исполняет все, что [Хаджи] ни прикажет. Когда Хаджи будет передвигаться, пусть все попавшиеся ему на пути калмыки и мусульмане дают [ему] верховых лошадей. Если у народа Хаджи (10) пропадет скот $(m \bar{a} l)$, и если какой бы то ни было калмык окажется вором, пусть этот калмык без судебного разбирательства (dīwānsïz) выплатит [стоимость] этого скота. Если [какой бы то ни было] калмык зайдет на выделенную ${ }^{31}$ [Хаджи для кочевья] землю без разрешения, пусть Хаджи судит сам (11) либо приведет [его] ко мне. Пусть повинуются моему приказу видевшие либо слышавшие эту грамоту. Пусть не будет [никто из] народа Хаджи ясырем ${ }^{32}$ моим потомкам ${ }^{33}$; если захватит [кого-либо из подвластных Хаджи людей кто-либо из моих потомков], пусть немедленно вернет $^{34}$. (12) Также пусть свои сыновья и братья Хаджи не дают подвод (ilim wä ulaw) и не поставляют провианта ( arj) $)$ моим потомкам $^{35}$, и не поставляют провиант ( $\chi a r j)$ в мое правление. Если у его народа остановится на постой постоялец (qonaq), пусть останавливается с разрешения (13) Хаджи. Ни русские, ни казанские татары, бежавшие без листа ${ }^{36}$, пусть у людей Хаджи не живут и с ними не кочуют. Сам [Хаджи] пусть будет готов на любую мою службу в соответствии с [этим] пожалованием (yarlïqač boyïnča) ${ }^{37}$. (14) Если калмыки украдут скот $(m \bar{a} l)$ у ногаев, пусть [тот, у кого украли] схватит и приведет [вора] к Хаджи, затем приведет ко мне. Если в результате судебного разбирательства (dīwān boÿ̈nča) выяснится, что [обвиняемый] вор, пусть его

к каким-нибудь начальникам [20, с. 477]. Здесь слово «дарага», очевидно, использовано в последнем значении.

*27 Перевод предположительный. В документе: ايكى شاى (ايكى شار؟) ايكى يكت.

* ${ }^{28}$ Возможный перевод: Каким образом совериают походы [на подданных ДондукДаши?] кубанские мирзы, таким же образом пусть водит в походы [на кубанцев?] [свое войско].

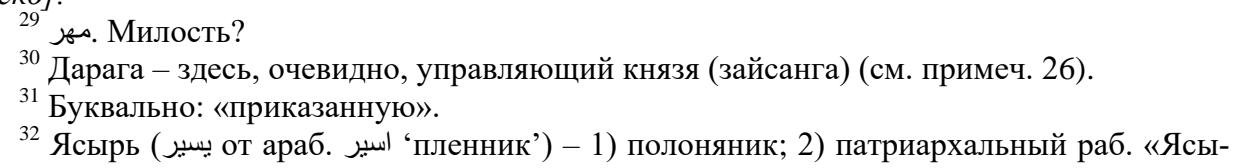
рами у ногайцев (в XVIII-XIX вв.) были полоняники, захваченные во время военных столкновений, а также преступники, отданные, если они не могли внести выкуп, в дом потерпевшего» [14, с. 149].

33 Буквально: «внукам».

${ }^{34}$ Буквально: «отдаст».

35 Буквально: «внукам».

${ }^{36}$ Т.е. без разрешительного документа, незаконно.

37 Очевидно, имеются в виду условия, на которых Мустафе-хаджи была пожалована его должность. 
карает ${ }^{38}$ Хаджи. Если будет проезжать путник, (15) по получении об этом известия от кого бы то ни было, пусть Хаджи отпустит его допросив, когда [кто-либо] прибудет, пусть [Хаджи также его] допросит, и известит меня.

По причине вражды, случившейся между Хаджи и его (16) народом, [я провел расследование], расспросил их ${ }^{39}$ и расспросил Хаджи. Народ оказался неправ, а Хаджи - прав, [после чего], отпустив вину народа, я вновь пожаловал $^{40}$ ему (17) его народ. Затем Хаджи, бив челом, попросил: "Если Вы пожалуете ${ }^{41}$ мне этот народ, дайте [его] своей грамотой и государевой печатью -

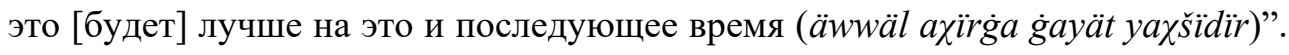
(18) Посему в год лошади в семнадцатый день первого осеннего месяца была написана и утверждена моей печатью эта жалованная грамота (yarlïqač).

(19) Моему приказу *да повинуются, да повинуются, да повинуются ${ }^{42}$.

Хан Дондук-Даши.

В верхней левой части листа той же рукой помета арабицей по-тюркски: В 1749 году сентября 17 дня.

\section{СПИСОК ЛИТЕРАТУРЫ}

1. Арсланов Л.Ш. Язык алабугатских татар Каспийского района Калмыцкой АССР: Учебное пособие. Казань, 1988. 105 c.

2. Арсланов Л.Ш., Викторин В.М. Астраханские татары // Материалы по истории татарского народа. Казань: Институт языка, литературы и истории им. Г. Ибрагимова AH PT, 1995. C. 334-366.

3. Атлас Российский, состоящий из девятнадцати специальных карт, представляющих Всероссийскую империю с пограничными землями. СПб.: Типография Императорской Академии наук, 1745. 20 л.

4. Баскаков Н.А. Ногайский язык и его диалекты: грамматика, тексты и словарь. М.; Л.: Издательство Академии наук СССР, 1940. 272 с.

5. Белоусов С.С. Калмыкия во второй половине XIX в. // История Калмыкии с древнейших времен до наших дней: в 3-х т. Элиста: ГУ «Издательский дом «Герел», 2009. T. 1. C. 514-559.

6. Бутков П.Г. Материалы для новой истории Кавказа с 1722 по 1803 год. СПб.: Типография Императорской Академии наук, 1869. Ч. 1. xxvi + 548 c.

7. Габдрахман Гомәри: Фәнни-биографик жыентык / Төзүче-автор С. Рәхимов. Казан: Рухият, 2002. 384 б.

8. Голстунский К.Ф. Монголо-ойратские законы 1640 года, дополнительные указы Галдан-Хун-Тайджия и законы, составленные для волжских калмыков при калмыцком хане Дондук-Даши. СПб.: Типография Императорской Академии наук, 1880. $16+144 \mathrm{c}$.

\footnotetext{
${ }^{38}$ Буквально: «казнит, рубит» (شابسون).

${ }^{39}$ Т.е. людей, подвластных Мустафе-хаджи.

${ }^{40}$ Буквально: «дал».

${ }^{41}$ Буквально: «дадите».

* 42 Буквально: «да повинуется, да повинуется, да повинуется».
} 
9. Документы по истории Волго-Уральского региона XVI-XIX веков из древлехранилищ Турции: сборник документов / Мустакимов И.А. (ред.). Казань: Гасыр, 2008. $464 \mathrm{c}$.

10. Жамщарано Ц. Жалованная грамота Сецен-хана, данная ламе ЛубсанБайдубу // Сергею Федоровичу Ольденбургу к пятидесятилетию научно-общественной деятельности (1882-1932): сборник статей. Л.: Издательство Академии наук CCCP, 1934. С. $185-194$.

11. Закруткин B.A. К истории изучения «Джангара» // Калмыцкий эпос «Джангар» / Закруткин В.А. (ред.). Ростов н/Д.: Областное книжное издательство, 1940. C. 6-88.

12. Кабардино-русские отношения в XVI-XVIII вв.: документы и материалы, T. 1: XVI-XVII вв. М.: Издательство Академии наук СССР, 1957. xvi + 478 c.

13. Кабардино-русские отношения в XVI-XVIII вв.: документы и материалы, T. 2: XVIII в. М.: Издательство Академии наук СССР, 1957. vii + 424 с.

14. Калмыков И.Х., Керейтов Р.Х., Сикалиев А.И. Ногайцы: Историко-этнографический очерк. Черкесск: Ставропольское книжное издательство; Карачаево-Черкесское отделение, 1988. 230 с.

15. Калмыцкая степь Астраханской губернии по исследованиям Кумо-Манычской экспедиции. СПб.: Министерство государственного имуществ, 1868. 300 с.

16. Калмыцко-русский словарь / Муниев Б.Д. (ред.). М.: Издательство «Русский язык», 1977. $765 \mathrm{c.}$

17. Клепиков C.A. Филиграни и штемпели на бумаге русского и иностранного производства XVII-XX века. М.: Издательство Всесоюзной Книжной палаты, 1959. $306 \mathrm{c}$.

18. Колесник В.И. Последнее великое кочевье: переход калмыков из Центральной Азии в Восточную Европу и обратно в XVII и XVIII веках: Автореф. дисс.... д.и.н. Волгоград, 2003. 54 с.

19. Лемерсье-Келькеже Ш. Волжские калмыки между Российской и Османской империями в период правления Петра Великого (по документам Османского архива) // Восточная Европа Средневековья и раннего Нового времени глазами французских исследователей: Сборник статей. Казань: Инст. истории АН РТ, 2009. С. 255-271.

20. Масленицкий Т.Г. Топографическое описание Симбирского наместничества 1785 г. // Научно-справочный фонд Государственного архива Ульяновской области. Режим доступа: http://www.simbir-archeo.narod.ru/Russian/18vek/maslenizkiy/ calmyki.htm (дата обращения: 11.06.2020).

21. Материалы по истории Башкирской АСCP, Часть I: Башкирские восстания в XVII и первой половине XVIII вв. / Чулошников А. (ред.). М.; Л.: Издательство Академии наук СССР, 1936. $631 \mathrm{c}$.

22. Новосельский А.А. Борьба Московского государства с татарами в первой половине XVII века. М.; Л.: Издательство Академии наук СССР, 1948. 447 с.

23. Соловьев С.М. Сочинения, Кн. VI: История России с древнейших времен. М.: Мысль, 1991. Т. 11-12. 671 с.

24. Сусеева Д.А. Письма хана Аюки и его современников (1714-1724): опыт лингвосоциологического исследования. Элиста: АПП «Джангар», 2003. 456 с.

25. Тепкеев B.T. Русско-калмыцкие переговоры и шерть 1673 г. // Вестник Калмыцкого института гуманитарных исследований РАН. 2010. № 1. С. 46-52.

26. Трепавлов В.В. История Ногайской Орды. М.: Восточная литература, 2001. $752 \mathrm{c}$.

27. Усманов М.A. Жалованные акты Джучиева Улуса XIV-XVI вв. Казань: Издательство Казанского университета, 1979. 321 с. 
28. Хисамова Ф.М. Татароязычные грамоты XVII-XVIII вв. // Истоки татарского литературного языка. Казань: Институт языка, литературы и истории им. Г. Ибрагимова Казанского филиала АН СССР, 1988. С. 57-71.

29. Цыбульский В.В. Лунно-солнечный календарь стран Восточной Азии с переводом на даты европейского календаря (с 1 по 2019 г.н.э.). М.: Наука, 1987. 382 с.

30. Цюрюмов А.В., Курапов А.А. Из истории калмыцко-тибетских контактов XVII-XVIII вв. // Oriental Studies. 2019. Vol. 46(6). P. 1050-1061. https://doi.org /10.22162/2619-0990-2019-46-6-1050-1061

31. Al-Hā̄ǰ 'Abd al-Ġaffār Qürīmī. 'Umdat al-Tawārīĥ / Nšr. N. 'Āsim. Istānbūl: Maṭba'a-i 'āmire, 1343/1924-25. $257 \mathrm{~s}$.

32. Kalmyk Old-script Documents of Isaac Jacob Schmidt 1800-1810: Todo Biciq Texts, Transcription, Translation from the Moravian Archives at Herrnhut / Krueger J.R., Service R.G. (eds). Wiesbaden: Harrassowitz Verlag, 2002. 214 p.

33. Matériaux pour servir à l'histoire du Khanat de Crimée. Extrait, par ordre de l'Académie impériale des sciences, des archives centrales du Ministère des affaires étrangères, à Moscou / Veliaminof-Zernof W. (ed.). St. Petersbourg: Academie des Sciences, 1864. ix $+940 \mathrm{p}$.

Сведения об авторах: Ильяс Альфредович Мустакимов - кандидат исторических наук, доцент Института международных отношений Казанского федерального университета (420008, ул. Пушкина, 1/55, Казань, Российская Федерация); старший научный сотрудник Национальной библиотеки Республики Татарстан (420111, ул. Кремлевская, 33, Казань, Российская Федерация); ORCID: 0000-0002-0052-5136, ResearcherID: AAG-5119-2020. E-mail: imus2007@mail.ru

Гульчира Махмутовна Ханнанова - научный сотрудник Института языка, литературы и искусства им. Г. Ибрагимова Академии наук Республики Татарстан (420111, ул. К. Маркса, 12/4, Казань, Российская Федерация); ORCID: 0000-0003-0488-6200. Email: ghan2003@mail.ru

Поступила 16.03.2021 Принята к публикации 28.05.2021

Опубликована 29.06.2021

\section{REFERENCES}

1. Arslanov L.Sh. Yazyk alabugatskikh tatar Kaspiyskogo rayona Kalmytskoy ASSR: Uchebnoe posobie [The Language of Alabugat Tatars Living in the Caspian Region of Kalmyk ASSR: Tutorial]. Kazan, 1988. 105 p. (In Russian)

2. Arslanov L.Sh., Viktorin V.M. Astrakhanskie tatary [The Astrakhan' Tatars]. Materialy po istorii tatarskogo naroda [Materials on the History of Tatar People]. Kazan: Institute for Language, Literature, and History of Tatarstan Academy of Sciences, 1995, pp. 334-366. (In Russian)

3. Atlas Rossiyskiy, sostoyashchiy iz devyatnadtsati spitsial'nykh kart, predstavlyayushchikh Vserossiyskuyu imperiyu s pogranichnymi zemlyami [Russian Atlas, Consisting of Nineteen Special Maps Representing the All-Russian Empire with Border Lands]. St. Petersburg: Imperial Academy of Sciences' Typography, 1745. 20 fol. (In Russian)

4. Baskakov N.A. Nogayskiy yazyk i yego dialekty: grammatika, teksty i slovar' [Nogay Language and Its Dialects: Grammar, Texts, and Vocabulary]. Moscow; Leningrad: Publishing house of the USSR Academy of Sciences, 1940. 272 p. (In Russian) 
5. Belousov S.S. Kalmykiya vo vtoroy polovine XIX v. [Kalmykia in the second half of nineteenth century]. Istoriya Kalmykii s drevneyshikh vremen do nashikh dney [History of Kalmykia from the Most Ancient Times to the Present Day]. Elista: GU Gerel, 2009, vol. 1, pp. 514-559. (In Russian)

6. Butkov P.G. Materialy dlya novoy istorii Kavkaza s 1722 po 1803 god [Materials for the New History of Caucasus from 1722 to 1803]. St. Petersburg: Imperial Academy of Sciences' Typography, 1869, part 1. xxvi + 548 p. (In Russian)

7. Gabdrakhman Gomari: Fanni-biografik jyentyk [Gabdrakhman Gomari: Scientific and biographic compilation]. Rakhimov S. (ed.). Kazan: Rukhiyat, 2002. 384 p. (In Tatar)

8. Golstunskiy K.F. Mongolo-oyratskie zakony 1640 goda, dopolnitel'nye ukazy Galdan-Khun-Tayjiya i zakony, sostavlennye dlya volzhskikh kalmykov pri kalmytskom khane Donduk-Dashi [The Mongol-Oyrat Laws of 1640, Additional Edicts of GaldanKhun-Tayji, and Laws Drawn Up for the Volga Kalmyks under the Kalmyk Donduk-Dashi Khan]. St. Petersburg: Imperial Academy of Sciences' Typography, 1880. $16+144$ p. (In Russian)

9. Dokumenty po istorii Volgo-Ural'skogo regiona XVI-XIX vekov iz drevlekhranilishch Turtsii: sbornik dokumentov [Documents on the History of the Volga-Ural Region from the sixteenth to nineteenth century from Tuskish Archives: Collection of Documents]. Mustakimov I.A. (ed.). Kazan: Gasyr, 2008. 464 p. (In Russian)

10. Zhamtsarano Ts. Zhalovannaya gramota Setsen-khana, dannaya lame LubsanBaydubu [Setsen Khan's charter issued to Lama Lubsan-Baydub]. Sergeyu Fedorovichu Ol'denburgu $k$ pyatidesyatiletiyu nauchno-obshchestvennoy deyatel'nosti (1882-1932): sbornik statey [To Sergey Fedorovich Oldenburg on the Fiftieth Anniversary of His Research and Public Activity (1882-1932): Collected Papers]. Leningrad: Publishing house of the USSR Academy of Sciences, 1934, pp. 185-194. (In Russian)

11. Zakrutkin V.A. K istorii izucheniya "Dzhangara" [Notes on the history of the study of "Jangar"]. Kalmytskiy epos "Dzhangar" [The Kalmyk Epic "Jangar"]. Zakrutkin V.A. (ed.). Rostov-on-Don: Regional publishing house, 1940, pp. 6-88. (In Russian)

12. Kabardino-russkie otnosheniya v XVI-XVIII vv.: dokumenty i materialy: XVI-XVII $v v$. [Kabardinian-Russian Relations from the sixteenth to eighteenth century: Documents and Materials, Vol. 1: The sixteenth and seventeenth centuries]. Moscow: Publishing house of the USSR Academy of Sciences, 1957. xvi +478 p. (In Russian)

13. Kabardino-russkie otnosheniya v XVI-XVIII vv.: dokumenty $i$ materialy [Kabardinian-Russian relations during the $16^{\text {th }}-18^{\text {th }}$ centuries: documents and materials]. Vol. 2: $18^{\text {th }}$ century. Moscow: Publishing house of the USSR Academy of Sciences, 1957. VII, 424 p. (In Russian)

14. Kalmykov I.Kh., Kereytov R.Kh., Sikaliev A.I. Nogaytsy: Istoriko-etnograficheskiy ocherk [The Nogays: Historical and Ethnographic Essay]. Cherkessk: Stavropol book publishing house, Karachay-Cherkessian branch, 1988. 230 p. (In Russian)

15. Kalmytskaya step' Astrakhanskoy gubernii po issledovaniyam Kumo-Manychskoy ekspeditsii [The Kalmyk Steppes of Astrakhan Province according to Research of the Kumo-Manych Expedition]. St. Petersburg: Ministry of State Property, 1868. 300 p. (In Russian)

16. Kalmytsko-russkiy slovar' [Kalmyk-Russian Dictionary]. Muniev B.D. (ed.). Moscow: Russian language publishing house, 1977. 765 p. (In Russian)

17. Klepikov S.A. Filigrani $i$ shtempeli na bumage russkogo $i$ inostrannogo proizvodstva XVII-XX veka [Watermarks and Stamps on Paper of Russian and Foreign Production from the seventeenth to twenties century]. Moscow: All-Union Book Chamber, 1959. 306 p. (In Russian)

18. Kolesnik V.I. Poslednee velikoe kochev'e: perekhod kalmykov iz Tsentral'noy Azii v Vostochnuyu Evropu i obratno v XVII i XVIII vekakh: Avtoref. diss.... d.i.n. [The Last 
Great Nomadism: the Transition of the Kalmyks from Central Asia to Eastern Europe and Back in the seventeenth and eighteenth centuries: Abstract of PhD Thesis]. Volgograd, 2003. 54 p. (In Russian)

19. Lemercier-Quelquejay Ch. Volzhskie kalmyki mezhdu Rossiyskoy i Osmanskoy imperiyami v period pravleniya Petra Velikogo (po dokumentam Osmanskogo arkhiva) [Les Kalmuks de la Volga entre l'Empire russe et l'Empire ottoman sous le règne de Pierre le Grand (d'après les documents des Archives Ottomanes)]. Vostochnaya Evropa Srednevekov'ya i rannego Novogo vremeni glazami frantsuzskikh issledovateley: Sbornik statey [Eastern Europe of the Middle Ages and Early Modern Times through the Eyes of French Researchers: Collection of Articles]. Kazan: Marjani Institute of History of Tatarstan Academy of Sciences, 2009, pp. 255-271. (In Russian)

20. Maslenitskiy T.G. Topograficheskoe opisanie Simbirskogo namestnichestva $1785 \mathrm{~g}$. [Topographical Description of the Simbirsk Viceroyalty of 1785]. Nauchno-spravochnyi fond Gosudarstvennogo arkhiva Ul'yanovskoy oblasti [Scientific Reference Fund of the State Archives of the Ulyanovsk Region]. Available at: http://www.simbirarcheo.narod.ru/Russian/18vek/maslenizkiy/calmyki.htm) (accessed: 11.06.2020). (In Russian)

21. Materialy po istorii Bashkirskoy ASSR, Chast' I: Bashkirskie vosstaniya $v$ XVII $i$ pervoy polovine XVIII vv. [Materials on the History of the Bashkir ASSR, Part I: Bashkir Revolts in the seventeenth and first half of eighteenth centuries]. Chuloshnikov A. (ed.). Moscow; Leningrad: Publishing house of the USSR Academy of Sciences, 1936. 631 p. (In Russian)

22. Novosel'skiy A.A. Bor'ba Moskovskogo gosudarstva s tatarami v pervoy polovine XVII veka [The Struggle of the Muscovite State with Tatars in the first half of seventeenth century]. Moscow; Leningrad: Publishing house of the USSR Academy of Sciences, 1948. 447 p. (In Russian)

23. Solov'yev S.M. Sochineniya, Kniga VI: Istoriya Rossii s drevneyshikh vremen [Essays, Book 6: History of Russia since the Most Ancient Times]. Moscow: Thought, 1991, vol. 11-12. 671 p. (In Russian)

24. Suseeva D.A. Pis'ma khana Ayuki i yego sovremennikov (1714-1724): opyt lingvosotsiologicheskogo issledovaniya [Letters of Ayuka Khan and His Contemporaries (1714-1724): Experience of Linguo-Sociological Research]. Elista: APP “Jangar”, 2003. 456 p. (In Russian)

25. Tepkeev V.T. Russko-kalmytskie peregovory i shert' 1673 g. [Russian-Kalmyk negotiations and shert' (treaty) of 1673]. Vestnik Kalmytskogo instituta gumanitarnykh issledovaniy RAN [Bulletin of the Kalmyk Institute for Humanitarian Research of the Russian Academy of Sciences]. 2010, no 1, p. 46-52. (In Russian)

26. Trepavlov V.V. Istoriya Nogayskoy Ordy [History of the Nogay Horde]. Moscow: Oriental literature, 2001. 752 p. (In Russian)

27. Usmanov M.A. Zhalovannye akty Dzhuchieva Ulusa XIV-XVI vv. [Granted Acts of the Ulus of Jochi, from the fourteenth to sixteenth centuries]. Kazan: Kazan University publishing house, 1979. 321 p. (In Russian)

28. Khisamova F.M. Tataroyazychnye gramoty XVII-XVIII вв. [Tatar-language charters of the seventeenth and eighteenth century]. Istoki tatarskogo literaturnogo yazyka [Origins of the Tatar Literary Language]. Kazan: Institute for Language, Literature, and History of the Kazan Branch of the USSR Academy of Sciences, 1988, pp. 57-71. (In Russian)

29. Tsybul'skiy V.V. Lunno-solnechnyi kalendar' stran Vostochnoy Azii s perevodom na daty yevropeyskogo kalendarya (s 1 po 2019 g.n.e.) [Lunar and Solar Calendar of East Asian Countries with Translation to the Dates of the European Calendar (from 1 to 2019 AD)]. Moscow: Nauka, 1987. 382 p. (In Russian) 
30. Tsyuryumov A., Kurapov A. Iz istorii kalmytsko-tibetskikh kontaktov XVIIXVIII vv. [From the history of Kalmyk-Tibetan Contacts of the seventeenth and eighteenth century]. Oriental Studies. 2019, vol. 46(6), pp. 1050-1061. (In Russian)

31. Al-Hāj̃̄ 'Abd al-Ġaffār Qürīmī. 'Umdat al-Tawārīĥ. Nšr. N. 'Āsim. Istānbūl: Maṭba'a-i 'āmire, 1343/1924-25. 257 p. (In Ottoman Turkish).

32. Kalmyk Old-script Documents of Isaac Jacob Schmidt 1800-1810: Todo Biciq Texts, Transcription, Translation from the Moravian Archives at Herrnhut. Krueger J.R., Service R.G. (eds). Wiesbaden: Harrassowitz Verlag, 2002. 214 p.

33. Matériaux pour servir à l'histoire du Khanat de Crimée. Extrait, par ordre de l'Académie impériale des sciences, des archives centrales du Ministère des affaires étrangères, à Moscou. Veliaminof-Zernof W. (ed.). St. Petersbourg: Academie des Sciences, 1864. ix + 940 p. (In Tatar and Ottoman Turkish)

About the authors: Ilyas I. Mustakimov - Cand. Sci. (History), Associate Professor of the Institute of International Relations, Kazan Federal University (1/55, Pushkin Str., Kazan 420008, Russian Federation); Senior Research Fellow of the National Library of the Republic of Tatarstan (33, Kremlevskaya Str., Kazan 420111, Russian Federation); ORCID: 0000-0002-0052-5136, ResearcherID: AAG-5119-2020. E-mail: imus2007@mail.ru

Gul'chira M. Khannanova - Research Fellow of the G.Ibragimov Institute of Language, Literature and Art of Tatarstan Academy of Sciences (12/4, Karl Marx Str., Kazan 420111, Russian Federation); ORCID: 0000-0003-0488-6200. E-mail: ghan2003@mail.ru 


\title{
РЕЦЕНЗИЯ НА КНИГУ:
}

\section{ЗЛЫГОСТЕВ В.А. ГЕРОИ «СОКРОВЕННОГО СКАЗАНИЯ»}

\author{
И.В. Антонов \\ Институт этнологических исследований им. Р.Г. Кузеева \\ Уфимского федерального исследовательского центра \\ Российской академии наук \\ Уфа, Российская Федерачия \\ igan73@yandex.ru
}

Цель исследования: в статье анализируется новая книга независимого историка Валерия Злыгостева, написанная в историко-биографическом жанре. Она посвящена выдающимся деятелям средневековой истории монголов, их союзников и противников, чьи имена донесли до нас письменные источники. Книга охватывает хронологический период VIII-XIII веков, ее географические рамки ограничены территорией Монгольской империи от Средиземного моря до Тихого океана. Прослежен процесс становления монгольской государственности, образования Монгольской империи и расширения ее границ (до окончания эпохи завоеваний в 1270-х годах).

На основе монгольской хроники 1240 года, традиционно называемой «Сокровенным сказанием», и других источников автор реконструирует биографии всех персонажей, действовавших в обозначенных пространственно-временных рамках.

Научная новизна исследования заключается в том, что впервые в российской историографии написаны биографии Героев монгольской истории второго и третьего плана, показана их роль в различных военно-политических событиях, завершившихся созданием величайшей мировой империи. Особое внимание уделено так называемому «темному» периоду истории монголов до середины XII века, то есть появления на свет Чингизхана. Этот период, до сих пор недостаточно разработанный в историографии, очень важен в плане выявления предпосылок последующего объединения Монголии, а также завоеваний Чингизхана и его преемников в Азии и Европе.

Автором проделана огромная работа, проведен сравнительный анализ всех доступных источников, выявлены все возможные, даже самые незначительные, детали биографии того или иного героя. Книга рекомендуется всем, интересующимся средневековой историей Евразии.

Ключевые слова: герои «Сокровенного сказания», история монголов, эпоха средневековья

Для цитирования: Антонов И.В. Рецензия на книгу: Злыгостев В.А. Герои «Сокровенного сказания» // Золотоордынское обозрение. 2021. Т. 9, № 2. С. 438-450. DOI: $10.22378 / 2313-6197.2021-9-2.438-450$ 


\title{
BOOK REVIEW: ZLYGOSTEV V.A. GEROI "SOKROVENNOGO SKAZANIYA" [HEROES OF THE "SECRET HISTORY”]
}

\author{
I.V. Antonov \\ Institute of Ethnological Studies named after R.G. Kuzeev \\ of the Ufa Federal Research Center of Russian Academy of Sciences \\ Ufa, Russian Federation \\ igan73@yandex.ru
}

\begin{abstract}
Research objectives: This article analyzes a new book by independent historian, Valery Zlygostev, written in the historical, biographical genre. The book is dedicated to outstanding figures in the medieval history of the Mongols, their allies, and opponents, as have been preserved in written sources. It discusses the territories eventually covered by the Mongol Empire, stretching from the Mediterranean Sea to the Pacific Ocean, during the period from the eighth to thirteenth century. Zlygostev traced the process of the establishment of Mongolian statehood, the formation of the Mongol Empire, and the expansion of its borders until the end of the era of conquests in the 1270s. The author reconstructs the biographies of all the characters of this period on the basis of the Mongol chronicle of c. 1240 , traditionally called the "Secret History," alongside other sources.

The scholarly novelty of the research lies in the presentation of the secondary and tertiary heroes of Mongolian history and their role in various military and political events that culminated in the creation of the greatest world empire in history. Particular attention is paid to the so-called "dark" period in the history of the Mongols stretching until the middle of the twelfth century, that is, the period of Chinggis Khan's birth. This period is still insufficiently analyzed in historiography and yet is very important for clarifying the prerequisite conditions which brought about the subsequent unification of Mongolia and the conquests of Chinggis Khan and his successors in Asia and Europe.

The author has done a tremendous job of analyzing all available sources and identifying all possible details of the biography of certain heroes. The book is recommended for everyone interested in the medieval history of Eurasia.
\end{abstract}

Keywords: heroes of the "Secret History", history of the Mongols, Middle Ages

For citation: Antonov I.V. Book Review: Zlygostev V.A. Geroi "Sokrovennogo skazaniya" [Heroes of the "Secret History"]. Zolotoordynskoe obozrenie=Golden Horde Review. 2021, vol. 9, no. 2, pp. 438-450. DOI: 10.22378/2313-6197.2021-9-2.438-450

Независимый уфимский историк Валерий Анатольевич Злыгостев уже известен в научном сообществе как автор и соавтор целого ряда монографий по истории Монгольской империи и Улуса Джучи $[1 ; 2 ; 4 ; 3 ; 5]$. Особенно плодотворно автор работает в историко-биографическом жанре. Его монографии о Субэдэе и Токтамыше, по нашему мнению, достойны публикации в серии биографий «Жизнь замечательных людей». В том же жанре написана и рецензируемая книга (Злыгостев В.А. Герои «Сокровенного сказания». Уфа: Альфа-реклама, 2018. 806 с.). Поскольку это не монография, я бы назвал ее научной энциклопедией. Эту книгу нельзя отнести к числу научнопопулярных, она написана непосредственно по источникам и поэтому рассчитана не на массового читателя, а на исследователя, работающего с источниками. Энциклопедией она является по широте охвата материала, любому, даже самому незначительному, персонажу «Сокровенного сказания» посвящена отдельная статья. Безусловно, первое, что необходимо отметить, это 
грандиозность проделанной работы. Над энциклопедией обычно работает целый коллектив, энциклопедии принято считать справочными изданиями, поскольку в научном плане в них нет ничего нового. Эта энциклопедия исключение. Она написана одним человеком и носит научно-исследовательский характер. Сама тема, за которую взялся автор, не является в историографии настолько разработанной, чтобы на материале широко известных работ можно было подготовить справочное издание. Многие, до сих пор никем не поставленные вопросы, автор поднимает впервые, рассматривает никем не замеченные обстоятельства, в чем, несомненно, заключается научная новизна рецензируемой работы. В отечественной историографии подобного рода работ не имеется. Рецензируемую книгу можно сравнить только с «Энциклопедией Монголии и Монгольской империи», изданной Кристофером Атвудом в США [15].

Спектр биографий поистине разнообразен. Прежде всего, необходимо обратить внимание на «многонациональный» состав участников коллективного действа. Это и сами монголы, одноплеменники Чингизхана, и представители других монгольских племен (татары, кераиты, найманы, джелаиры, меркиты и все прочие), и представители других стран и народов (цзиньские императоры, тангутские цари, уйгурские идикуты, кыпчакские ханы, хорезмские шахи, багдадские халифы, их приближенные, чиновники и полководцы). Разнообразен и социальный состав Героев: это представители не только потомственной знати, но и самых низших слоев общества - воины, слуги, пастухи. Таковы табунщики Бадай (С. 66-67) и Кишлик (С. 330), находившиеся в рабской зависимости у Еке-Церена, внука Хабул-хагана. Таков Сорган-Шира - рядовой арат, находившийся в «крепостной» зависимости от тайчиутского нойона Тодоге (С. 470-472), его сыновья Чилаун (С. 722-724) и Чимбай (С. 726) и дочь Хадаан (С. 618). Конечно, прославившись, эти люди были наделены Чингизханом высокими должностями и титулами, но так и остались выдвиженцами из низов. Хоахчин, служанка в семействе покойного Есугея, прославилась спасением Тэмуджина и преданной службой Борте, захваченной меркитами, но Чингизхан о ее заслугах даже не вспомнил, а ее имя после освобождения из плена исчезает со страниц «Сокровенного сказания» (С. 641-642). Но вот одинокий бродяга из племени татар Харгил-Шира прославился только тем, что попытался убить сына Чингизхана Толуя и был тут же прикончен (С. 627-628), хотя и успел войти в историю. Материал условно можно разделить на несколько групп по этнической и социальнопрофессиональной принадлежности Героев, месту и времени действия, конечно, определенная последовательность изложения была бы более удобной для читателя. Однако огромное количество Героев, исчисляемых сотнями, задает единственно возможный в таких условиях алфавитный принцип изложения. При упоминании других Героев даются ссылки на статьи с соответствующими названиями, что позволяет читателю сразу же «переключиться» на иных участников рассматриваемых событий. Естественно, объем статей неодинаков. Наряду с обширными биографиями сыновей и внуков Чингизхана некоторым его тысячникам уделено всего лишь по одному предложению. Ко всем своим Героям автор одинаково объективен - использует все доступные сведения, подвергая их критическому анализу. 
Правда, отсутствует биография самого главного Героя «Сокровенного сказания» - Чингизхана, кроме упоминания о нем (С. 727). Биографии Чингизхана в отечественной и зарубежной историографии давно уже написаны, и автор, как он сам признался в предисловии (С. 7), не счел нужным повторяться. Его задачей являлось написание биографий Героев второго и третьего плана. Что касается Чингизхана, то очерк о нем в 20-30, пусть даже 50 страниц, не сможет заменить специального монографического исследования. Тем не менее, главным Героем книги, бесспорно, остается Чингизхан.

В связи с тем, что самому знаменитому полководцу Чингизхана - Субэдэю - посвящена отдельная монография, его биография в книге дана обзорно (C. 484-495).

Все статьи написаны по строго определенным правилам. Вначале дается имя Героя во всех вариантах его написания на русском языке со ссылками на источники. Далее указывается племенная принадлежность. Затем следуют даты рождения и смерти. В тех случаях, когда эти даты в источниках не указаны, они рассчитываются предположительно, но с большой долей вероятности, исходя из дат первого и последнего упоминаний в источниках. Далее следуют сведения о родных и близких: родителях, братьях и сестрах, женах (мужьях), детях. Основная часть статьи представляет собой анализ всех дошедших до нас сведений о жизнедеятельности данного Героя, излагаемых в хронологическом порядке. При работе с источниками используется сравнительный метод, помогающий отделить достоверную информацию от сомнительной. Во многих случаях автор сталкивается с проблемой недостаточности имеющихся сведений, их отрывочности и противоречивости, что не помешало ему создать полноценные биографии всех вынесенных в заглавие Героев. Установив отдельные факты в жизни того или иного Героя, автор пытается восполнить образовавшиеся лакуны, хотя бы в предположительной форме определить, где находился и чем занимался его Герой, когда о нем нет никаких упоминаний в источниках. Таким образом, автор выстраивает собственную версию биографии каждого Героя. Это кропотливый, но необходимый труд, заслуживающий признания со стороны научной общественности.

Автором использованы все три издания памятника на русском языке $[11 ; 7$; 10]. Поскольку перевод П.И. Кафарова устарел, ссылки на него имеют характер уточнений. В основу книги положен академический перевод С.А. Козина, который выполнен по всем правилам современного языкознания, но, к сожалению, не сопровождается характеристикой памятника как исторического источника, комментариями и указателями. Новейший перевод А.В. Мелехина и Г.Б. Ярославцева использован в сравнительном плане. Этот перевод не заменяет собой перевода С.А. Козина (хотя в ряде случаев с ним расходится), но сопровождается характеристикой источника и историческими комментариями. Комментарии, однако, посвящены не всем изложенным событиям и носят далеко не полный характер. К сожалению, автор не использовал английский перевод с обширными историческими и филологическими комментариями Игоря де Рахевильца [16; 17]. Тем не менее, В.А. Злыгостев взял на себя смелость восполнить сложившуюся в отечественной историографии лакуну и написать полноценный комментарий, многократно превышающий объем самого памятника.

Из других источников использованы монгольские («Алтан тобчи» Лубсан Данзана), арабские и персидские (ан-Насави, ал-Асир, ал-Айни, Джузджани, 
Джувейни, Рашид ад-Дин, Вассаф, Хамдаллах Казвини, Гаффари, «Родословие тюрков», «Дополнительные сведения»), китайские («Юань ши», «Хэй-да шилюэ», «Мэн-да бэй-лу», «Шэн-у цинь-чжэн лу»), западноевропейские (Юлиан, Фома Сплитский, Иоанн де Плано Карпини, Гильом де Рубрук, Марко Поло, Клавихо), тюркские (Утемиш-хаджи, Абу-л-Гази, шеджере и предания), а также армянские и русские источники. Как видно, в распоряжении автора имелся полный набор сведений по истории Монгольской империи.

В списке литературы цитируемые издания расположены в порядке первого упоминания, что неудобно для больших работ. Источники не отделены от работ современных историков. Историография использована автором далеко не полностью. Автор избрал слишком широкую тему исследования. Изучить огромное количество литературы по этой теме никому не под силу. И все же избирательный подход автора вызывает удивление. Наряду с многочисленными ссылками на статьи из сборника «Татаро-монголы в Азии и Европе» [12] слабо использованы сборники научных трудов последних лет. Автор почему-то не использовал одну из последних монографий Р.Ю. Почекаева [9], имеющую самое непосредственное отношение к заявленной теме, несмотря на то, что эта монография вышла в свет за два года до окончания работы над книгой и продавалась в книжных магазинах г. Уфы. Это тем более странно, что многие другие монографии Р.Ю. Почекаева использованы, автор ссылается на них довольно часто, и даже сама книга, как мне показалось, написана стилем жизнеописаний, характерным для работ Р.Ю. Почекаева. Нет в списке литературы и книги А.Ю. Карпова, вышедшей уже вторым изданием [6]. Из работ иностранных авторов использованы только переведенные на русский язык, а это в основном научно-популярные работы. Знание иностранной литературы, безусловно, необходимо современному исследователю. В то же время не стоит предъявлять невыполнимых требований. Практически все источники по теме переведены на русский язык, новейшие переводы выполнены с учетом современных требований, имеется даже возможность сравнить разные варианты переводов для уточнения отдельных нюансов и деталей, что и сделано автором. Таким образом, источниковая база достаточно обширна и в полной мере доступна русскоязычному исследователю. Требование читать источники на языке оригинала представляется не только излишним, но и абсолютно нереальным. Другое дело - историография. Нельзя игнорировать работы на европейских языках по истории Монгольской империи. Имеются очень важные исследования на английском языке, непосредственно посвященные Героям «Сокровенного сказания». Например, в монографии Томаса Оллсена рассматривается период правления великого хана Мункэ [14], которому посвящен едва ли не самый крупный очерк книги (С. 390-419). Впрочем, выбор литературы дело автора. Книга написана главным образом на материале источников, а имеющиеся пробелы в историографии можно объяснить ограниченностью объема. Объем книги и без того составляет восемьсот страниц, набранных мелким шрифтом. Если расширить содержание книги за счет историографии, получился бы не один, а два или даже три тома.

Издание сопровождается авторским предисловием, вынесенными в приложения генеалогической и хронологической таблицами, глоссарием, а также указателем географических названий и списком литературы. Эпоха Героев «Сокровенного сказания», как видно из хронологического перечня дат и со- 
бытий, охватывает период с середины VIII века (упоминание в источнике о предках всех монголов Борте-Чино и Гоа-Марал) до 1276 года (падение державы Сун и конец эпохи монгольских завоеваний, о чем известно уже из других источников). Доведя повествование до 1270-х годов, автор, таким образом, прослеживает судьбы последнего поколения Героев «Сокровенного сказания». Необходимо отметить, что датировки событий ранней истории монголов в большинстве своем имеют условный характер. Таковы, например, даты рождения сыновей Чингизхана: Джучи - 1184 год, Чагатая - 1185 год, Угэдэя - 1186 год, Толуя - 1193 год. Даже дата рождения самого Тэмуджина - 1155 год - признается не всеми исследователями. Заслуга автора, конечно, не в том, что он рассчитал эти даты (точно их рассчитать невозможно из-за отсутствия прямых указаний в источниках), а в том, что он предложил собственную непротиворечивую версию хронологии событий, постоянно используемую в ходе изложения материала. Географические рамки исследования обозначены картами на форзацах книги, где показаны походы Чингизхана с 1184 года и монгольские завоевания до 1275 года. Это практически вся территория Евразии, включая Центральную и Восточную Европу, Сибирь и Дальний Восток (северная граница монгольских завоеваний условна), Ближний Восток, Индию и Вьетнам.

Трудно рецензировать работу, состоящую из отдельных очерков, каждый из которых имеет самостоятельный сюжет. В такой ситуации можно остановиться только на некоторых примерах, из которых видно, что автор выступает не просто как «статист», а как исследователь рассматриваемых событий. В.А. Злыгостев ставит «вопрос о поражении, которое поздней осенью 1223 года якобы понесли монголы от волжских булгар где-то в пределах среднего Итиля. Единственным источником, повествующим о поражении монголов, а по факту отступлении перед многократно превышавшем их численно противником, является сочинение Ибн ал-Асира». Ибн ал-Асир являлся современником описываемых событий, проживавшим в практически «прифронтовом» Мосуле, в непосредственной близости которого действовали тумены Джэбэ и Субэдэя. Жители города, избежавшие гибели, сами желали монголам смерти. «Поэтому информация о якобы неудачных действиях монголов в Среднем Поволжье в 1223 году, оказавшаяся через определенное время в руках Ибн ал-Асира, получила в его летописи должную оценку. Оценку побежденного. Разве не хотелось даже такому скрупулезному в своих сочинениях историку, как Инб ал-Асир, увидеть безжалостных злодеев-завоевателей поверженными? Ему захотелось, и он увидел» (Джэбэ. С. 269-270). Ибн алАсир пишет, что татары (монголы), разбив русских на Калке, «направились в Булгар в конце 620 года [4. II. 1223 - 23. I. 1224]. Когда жители Булгара услышали о приближении их к ним, они в нескольких местах устроили им засады, выступили против них (татар), встретились с ними и, заманив их до тех пор, пока они зашли за место засад, напали на них с тыла, так что они (татары) остались в середине; поял их меч со всех сторон, перебито их множество и уцелели из них только немногие. Говорят, что их было до 4000 человек» [13, с. 27-28]. Допустим, эти сведения Ибн ал-Асир получил непосредственно от волжских булгар. Они могли сосчитать количество погибших монголов, но не могли определить количество оставшихся в живых. У Ибн ал-Асира все получилось наоборот. Невольно возникает вопрос: а не поменял ли автор местами победителей и побеж- 
денных? Ведь он описал типично монгольскую тактику ведения боя с той лишь разницей, что применил ее по отношению не к монголам, а к их противникам. Даже если булгары тоже использовали подобную тактику, как ее могли не распознать такие испытанные полководцы, как Джэбэ и Субэдэй? Неужели они могли допустить такую досадную оплошность, пренебречь разведкой и зайти за место засад? Вопрос о том, кто победил в этой битве, остается открытым, но количество потерь среди монголов, несомненно, сильно завышено.

Много внимания справедливо уделено событиям Великого западного похода монгольских царевичей во главе с Бату. Как показал анализ событий, «фигура Бату в 1238-1240 годах исчезает из сводок военных действий». Как ни странно, именно в эти годы Бату вплотную занялся устройством своего улуса. Бури, Гуюк и Аргасун, возмущенные самоустранением Бату от текущих дел, выступили против него, собравшись на победный пир зимой 1239/40 года. Бату пожаловался Угэдэю, который отозвал зарвавшихся царевичей в Монголию (Бури. С. 132-133). Бату не упустил случая обвинить своих соперников в оскорблении и требовать их наказания по законам военного времени. Но кто же из них был прав: Бату, фактически отказавшийся исполнять свои прямые обязанности, или его соперники, «усердствовавшие» на ратном поприще? Ответ на этот вопрос автор оставляет открытым.

Автор отмечает: «В среде выходцев из “золотого рода" появилось крыло недовольных действиями (точнее, бездействием. - И.А.) Бату, и крыло это возглавил Гуюк». В донесении Бату Угэдэю о случившемся, «по-видимому, помимо основного текста, приведенного в “Сокровенном сказании”, присутствовал и откровенный наговор: вот, де, Гуюк плохо воевал...». Гуюк же, страхуясь от наговоров, отправил в Каракорум свой отчет о проделанных трудах, о чем записано в «Юань ши». По мнению В.А. Злыгостева, Гуюк «хотел преувеличить свои заслуги и смягчить гнев великого каана» (Гуюк. С. 187-188). Но надо ли было Гуюку преувеличивать свои заслуги: даже если он плохо воевал, то Бату вообще не воевал. Очевидно, за неимением достаточных аргументов для дискредитации Гуюка в глазах каана, Бату и состряпал свой наговор, т.е. использовал недопустимый прием фальсификации событий. Кстати, в книге постоянно используется не совсем корректное выражение «великий каан». Но каан - глава «золотого рода» - был один, единственный в своем роде, поэтому его нет необходимости называть еще и великим. В таком случае логичнее сказать «великий хан», если ханами могли титуловаться правители улусов.

По мнению В.А. Злыгостева, «Гуюк уже летом - осенью 1241 года прибыл ко двору Угэдэя, где его ожидал тяжелый разговор, чуть было не стоивший ему дальнейшей политической карьеры» (С. 189). Однако «Сокровенное сказание», сохранившее подробности этого тяжелого разговора, написано в 1240 году, поэтому Сказитель никак не мог описать события следующего года. Автор пишет, что «после унизительного для самолюбивого царевича приема в Каракоруме ему оставалось разве что удалиться в свой удел и ожидать позорного судилища» (С. 189), но, как сказано в источнике, Угэдэй отправил Гуюка не в свой удел, а отослал его обратно на Западный фронт.

Рассказывая о государе меркитов Тохтоа-беки, автор обращает внимание на то, что, согласно «Сокровенному сказанию», «Чиледу, первый муж Оэлун, 
и Чильгир-Боко, которому Борте была “передана на волю”, являлись братьями Тохтоа-беки. В последнем случае сомнения в правдивости информации излишни, так как Тохтоа не ввязался бы в войну с грозным триумвиратом (Ван-хан, Джамуха, Тэмуджин) из-за людей, далеких ему...» (С. 546). Очень краткий очерк посвящен младшему сыну Тохтоа-беки - Култукан-мэргэну. Рашид ад-Дин пишет, что Джучи просил Чингизхана сохранить жизнь Култукана, попавшего к нему в плен. Но Чингизхан это не одобрил, и Джучи пришлось казнить Култукана (С. 356-357). Не потому ли Джучи благоволил к Култукану, что тот мог быть его двоюродным братом? Однако появление на свет Джучи, не связанное в «Сокровенном сказании» с освобождением Борте из меркитского плена, не было для Чингизхана чем-то неожиданным; не приходится сомневаться в том, что он признал в нем родного сына. Автор показал, что официальная чингизидская идеология не допускает никаких сомнений относительно происхождения Джучи (Джучи. С. 242-243). Чего же еще можно ожидать от официальной идеологии?

Чингизхан не знал, чьим сыном был Джучи, но знал ли Чингизхан, чьим сыном был он сам? «Учитывая обстоятельства “умыкания” Есугеем Оэлун у ее законного мужа (Чиледу. - И.А.), невозможно не задаться вопросом: а был ли Есугей отцом Тэмуджина?» (Оэлун. С. 454, прим. 1). Правда, Чингизхана никто не подозревал в меркитском происхождении, хотя врагов у него было предостаточно, а враги могли пустить в ход любые средства, не только военные, но и пропагандистские. Неужели все недоброжелатели Чингизхана забыли использовать свой главный козырь? Автор смело ставит новые вопросы, не вписывающие в традиционные стереотипы. Разумеется, такие вопросы не прибавляют нам новых знаний, но заставляют несколько по-иному взглянуть на давно известные события истории монголов.

Разумеется, есть и такие моменты, где с автором можно поспорить. По мнению В.А. Злыгостева, меркиты, нашедшие убежище в Дешт-и Кыпчаке, не представляли никакой опасности для монголов: «нет в источниках и намека на желание Куду (меркитского предводителя. - И.А.) напасть на Чингизхана, располагавшего к тому времени более чем 100 тысячами сабель, зато есть масса фактов, подтверждающих обратное». Однако, как отмечает сам же В.А. Злыгостев, в Дешт-и Кыпчак вслед за меркитами «продолжали бежать все недовольные единовластием Чингизхана, и, кстати, не только единоплеменники Куду, но и представители самых разных родов». Кроме того, меркитов приняли под свое покровительство кыпчаки, отказав монголам в их выдаче (Куду. С. 337-338). Если сложить силы кыпчаков с силами меркитов и всех других монгольских родов, не пожелавших признать власть Чингизхана и бежавших от него в Дешт-и Кыпчак, ситуация получится более сложная. Еще неизвестно, у кого из них - нападавших или оборонявшихся - сабель было больше. В такой ситуации Чингизхан решил начать превентивную войну, не дожидаясь внезапного удара своих объединившихся противников. В источниках и в самом деле нет сведений о намерениях враждующих сторон, там описываются реальные исторические события.

Вряд ли можно считать представителем родовой знати башкир Майкыбия, который побывал в ставке Чингизхана с выражением полной покорности. Согласно шеджере рода ирякте, Майкы-бий входил в число визирей Чингизхана и ездил с ним на одной арбе, что у В.А. Злыгостева «вызывает улыб- 
ку» (С. 375-376). Кроме башкир-табынцев, к Майкы-бию возводят свою генеалогию не только казахские табынцы Младшего Жуза, но и все казахи Старшего Жуза, а также узбеки, каракалпаки и ногайцы. Уйшин Майкы-бий в кара-табынском шеджере - это Байку у Рашид ад-Дина, эмир тысячи в войске Джучи, происходивший из племени уйсун (ушин, хушин). Р.Г. Кузеев считал его собирателем и вождем племенной конфедерации во главе с табынцами в Дешт-и Кыпчаке, с началом монгольского вторжения вставшим на сторону завоевателей [8, с. 252-265]. В то время табынцы представляли собой единое целое и еще не влились в состав башкир и других народов. Поэтому считать Майкы-бия башкиром или казахом в одинаковой степени неправильно. Биография Байку в книге описана отдельно (С. 76). Майкы-бий отличался от него как будто тем, что пришел на службу к монголам после 1217 года (С. 76, прим. 1). Впрочем, дата его прихода на службу по имеющимся источникам не устанавливается.

Трудно согласиться с автором в том, что в новой политической ситуации, сложившейся после смерти Чингизхана, «если разобраться, Темуге (Темугеотчигин, младший сын Есугея - младший брат Чингизхана. - И.А.), как прямой наследник Есугея, имел все шансы занять великокаанский престол» (C. 521). Есугей не был кааном, а Темуге не был соперником Угэдэя, занявшего престол по завещанию Чингизхана. Поскольку Темуге не принадлежал к царскому роду Чингизхана, его, очевидно, нельзя называть царевичем. Его самовольная попытка захватить престол после смерти Угэдэя не получила поддержки со стороны царевичей.

В книге представлено достаточно много лиц, вовсе не упомянутых в «Сокровенном сказании». Алталун - любимая дочь Чингизхана; Алчжар полководец Угэдэя; Аньмухай - начальник камнеметной артиллерии; АригБука, третий сын Толуя; Ачжу - внук Субэдэй-бахадура; Бааритай-курчи тысячник правого крыла; Байдар - шестой сын Чагатая; Байджу - военачальник; Байку - тысячник Джучи; Барджу - тысячник левого крыла; Барулатай тысячник Чагатая; Бачман - кыпчакский вождь; Белькеши - третий сын Чагатая; Берке - третий сын Джучи; Беркечар - четвертый сын Джучи; Би-инь предполагаемый старший сын Чингизхана; Бувал - седьмой сын Джучи; Букур - тысячник левого крыла; Бурундай - племянник Боорчу. Список можно продолжить. Это личности, безусловно, значимые в монгольской истории, но не являющиеся Героями «Сокровенного сказания».

Стремление автора расширить список Героев за счет привлечения других источников понятно и вполне приемлемо. «Автор “Сокровенного сказания", порой не забывая упомянуть о ничтожнейшем персонаже, хотя бы единожды промелькнувшем на подмостках истории, ни словом не обмолвился о Елюй Чуцае» (С. 301). Так и автором рецензируемого издания во всех подробностях рассмотрены все персонажи «Сокровенного сказания», вплоть до самых «ничтожнейших». Но наряду с ними обширный очерк посвящен «архитектору» Монгольской империи - Елюй Чуцаю, который, возможно, непосредственно участвуя в создании «Сокровенного сказания», «лично о себе и своих свершениях решил скромно умолчать...» (С. 301). Другими предполагаемыми авторами главной книги монголов В.А. Злыгостев (вслед за монгольским исследователем С. Дуламом) считает Героев «Сокровенного сказания» - создателя уйгу- 
ро-монгольской письменности Тататунгу (С. 507) и его учеников - первого монгольского грамотея Шиги-Хутуху (C. 745) и нойона-тысячника Аргасунахорчи (С. 48). В таком случае допускается возможность коллективного авторства «Сокровенного сказания» (С. 750). Впрочем, все эти гипотезы уже известны в историографии. При современном состоянии источников мы, очевидно, так и не узнаем имя (имена) автора (авторов) «Сокровенного сказания».

К числу неупомянутых в «Сокровенном сказании» Героев относится сын Толуя Хубилай, очерк о котором получил название «Герой иной эпохи». Узнав о смерти Мункэ, его брат Ариг-Бука, остававшийся в Монголии «в качестве наместника, объявил себя регентом и занялся подготовкой съезда, на котором, как он надеялся, его объявят преемником почившего повелителя». Весной 1260 года он в срочном порядке созвал курултай, на котором был официально провозглашен кааном. Другой брат Хубилай, «имевший основания не признавать решение этого собрания в силу малочисленности участников, созвал собственный курултай в подконтрольных ему землях Северного Китая», 4 июня 1260 года он также был официально провозглашен кааном. Но «решение этого курултая тоже являлось незаконным - и из-за недостаточного кворума, и из-за проведения вне Монголии...» (С. 654). Таким образом, автор показал, что оба курултая были незаконными, созывались самими кандидатами, и победил тот из них, кто оказался сильнейшим. Ариг-Бука, хоть и созвал «свой» курултай в Монголии, сам не был заинтересован в соблюдении законности и торопился со своим избранием, пока не прибыли его соперники. Это была уже иная эпоха с иными стереотипами поведения, совсем не характерными для Героев «Сокровенного сказания».

В связи со сказанным могут возникнуть претензии не к содержанию книги, а к ее названию. Рассмотренные в ней персонажи являются Героями не только «Сокровенного сказания», но и «Истории завоевателя мира», «Сборника летописей», «Юань ши» и многих других источников. Суть, конечно, не в том, что они - Герои какого-либо произведения, а в том, что они - Герои монгольской истории. Автор, как уже отмечалось, привлекает все доступные источники, ни одному из них не отдавая предпочтения. Поэтому «Герои «Сокровенного сказания»» - весьма скромное название. Более адекватным названием могло быть такое: «Герои монгольской истории VIII-XIII веков». Впрочем, это всего лишь мнение рецензента. Автору, как говорится, виднее.

К сожалению, в тексте часто встречаются опечатки, что свидетельствует о невысоком уровне редакторской работы. Например, в очерке о Байдаре: «разорив этот главный опорный пункт поляков на Висле (Сандомир. - И.А.), монголы тогда же (13 февраля [1241 г. - И.А.]) нанесли поражение монгольскому (т. е. польскому. - И.А.) рыцарству в битве под Турском» (С. 68). В биографии Сангума: «Родился ок. 1250-х, погиб в 1203/04» (С. 462). В биографии Таян-хана: «Родился ок. 1260-х, убит летом 1204» (С. 509). Подобного рода опечатки (ясно, что не ошибки), когда вместо XII указан XIII век, встречаются и в других местах. Это, конечно, мелочи, но и мелочи имеют значение. В такой большой книге внимательному читателю нетрудно найти отдельные неточности и недоработки, но все они не умоляют впечатления большой работы, проделанной автором. 


\section{СПИСОК ЛИТЕРАТУРЫ}

1. Зльгостев В.А. Субэдэй. Всадник, покорявший вселенную. Уфа: ДизайнПолиграфСервис, $2011.396 \mathrm{c}$.

2. Зльггостев В.А. Тохтамыш. Уфа: ДизайнПресс, 2012. 472 с.

3. Злыгостев B.A. И нагрянула черная рать... Монгольское завоевание Южного Урала (1205-1245). Уфа: Китап, 2015. 132 с.

4. Иванов B.A., Зльгостев В.А., Антонов И.В. Южный Урал в эпоху средневековья (V-XVI века н. э.). Уфа: Башкирский государственный педагогический университет, 2013. $280 \mathrm{c}$.

5. Иванов В.А., Злыгостев В.А. Это были башкиры... Уфа: Китап, 2017. 128 с.

6. Карпов А.Ю. Батый. 2-е изд., испр. и доп. М.: Молодая гвардия, 2017. 348 с.

7. Козин C.A. Сокровенное сказание: монгольская хроника 1240 г. под названием Mongyol-un niyuca tobciyan. Юань чао би ши: монгольский обыденный изборник, Т. I: Введение в изучение памятника, перевод, тексты, глоссарии. М.; Л.: Институт востоковедения Академии наук СССР, 1941. 611 с.

8. Кузеев Р.Г. Происхождение башкирского народа: этнический состав, история расселения. М.: Наука, 1974. 571 с.

9. Почекаев Р.Ю. Узурпаторы и самозванцы «степных империй»: история тюрко-монгольских государств в переворотах, мятежах и иностранных завоеваниях. СПб.: Евразия, 2016. 378 с.

10. Сокровенное сказание монголов // Чингисиана: свод свидетельств современников / Мелехин А. (пер.). М.: Эксмо, 2009. С. 17-356.

11. Старинное монгольское сказание о Чингисхане / архимандрит Палладий (пер.). // Труды членов Российской духовной миссии в Пекине. СПб., 1866. T. IV. C. 3-260.

12. Татаро-монголы в Азии и Европе: сборник статей / Тихвинский С.Л. (ред.). Изд. 2-е, перераб. и доп. М.: Наука, 1977. 503 с.

13. Тизенгаузен В. Сборник материалов, относящихся к истории Золотой Орды, Т. I: Извлечения из сочинений арабских. СПб., 1884. хvi + 564 c.

14. Allsen T.T. Mongol Imperialism: The Policies of the Grand Qan Mongke in China, Russia, and the Islamic lands, 1251-1259. Berkeley; Los Angeles; London: University of California Press, 1987. 278 p.

15. Atwood C.P. Encyclopedia of Mongolia and the Mongol Empire. Bloomington: Indiana University, 2004. 678 p.

16. The Secret History of the Mongols: A Mongolian Epic Chronicle of the thirteenth century / Rachewiltz I. de (tr.). Leiden; Boston: Brill, 2006. Vol. 1-2. cxxvii + 1349 p.

17. The Secret History of the Mongols: A Mongolian Epic Chronicle of the thirteenth century / Rachewiltz I. de (tr.). Leiden; Boston: Brill, 2013. Vol. 3. xvi + 226 p.

Сведения об авторе: Игорь Владимирович Антонов - кандидат исторических наук, старший научный сотрудник отдела археологического наследия Южного Урала Института этнологических исследований им. Р.Г. Кузеева Уфимского федерального исследовательского центра РАН (450077, ул. Карла Маркса, 6, Уфа, Российская Федерация). E-mail: igan73@yandex.ru 


\section{REFERENCES}

1. Zlygostev V.A. Subedey. Vsadnik, pokoryavshiy vselennuyu [Subedei. Rider Who Conquered the Universe]. Ufa: Design Poligraph Service, 2011. 396 p. (In Russian)

2. Zlygostev V.A. Tohtamysh [Toqtamïsh]. Ufa: Design Press, 2012. 472 p. (In Russian)

3. Zlygostev V.A. I nagryanula chernaya rat'... Mongol'skoe zavoevanie Yuzhnogo Urala (1205-1245) [“And black army raided ...”. Mongol conquest of the Southern Urals (1205-1245)]. Ufa: Kitap, 2015. 132 p. (In Russian)

4. Ivanov V.A., Zlygostev V.A., Antonov I.V. Yuzhnyy Ural v epokhu srednevekov'ya (V-XVI veka n. e.) [The Southern Urals in the Middle Ages (from the fifth to sixteenth century)]. Ufa: Bashkir State Pedagogical University, 2013. 280 p. (In Russian)

5. Ivanov V.A., Zlygostev V.A. Jeto byli bashkiry... [These Were the Bashkirs]. Ufa: Kitap, 2017. 128 p. (In Russian)

6. Karpov A.Ju. Batyy [Batu]. Second edition. Moscow: Young guard, 2017. 348 p. (In Russian)

7. Kozin S.A. Sokrovennoe skazanie: mongol'skaya khronika 1240 g. pod nazvaniem Mongyol-un niyuca tobciyan. Yuan' chao bi shi: mongol'skiy obydennyy izbornik, Vol. I: Vvedenie v izuchenie pamyatnika, perevod, teksty, glossarii [The Secret History of the Mongols: Mongolian Chronicle of 1240 Titled Mongyol-un niyuca tobciyan, Vol. 1: Introduction to the Study of the Monument, Translation, Texts, Glossaries]. Moscow; Leningrad: Institute of Oriental Studies of the USSR Academy of Sciences, 1941. 611 p. (In Russian)

8. Kuzeev R.G. Proiskhozhdenie bashkirskogo naroda: etnicheskiy sostav, istoriya rasseleniya [Origin of the Bashkir People: Ethnic Composition, History of Resettlement]. Moscow: Nauka, 1974. 571 p. (In Russian)

9. Pochekaev R.Ju. Uzurpatory $i$ samozvantsy "stepnykh imperiy": istoriya tyurkomongol'skikh gosudarstv $v$ perevorotakh, myatezhakh $i$ inostrannykh zavoevaniyakh [Usurpers and Impostors of the "Steppe Empires": History of the Turkish-Mongol States in the Coups, Riots, and Foreign Conquests]. St. Petersburg: Eurasia, 2016. 378 p. (In Russian)

10. Sokrovennoe skazanie mongolov [The Secret History of the Mongols]. Chingisiana: svod svidetel'stv sovremennikov [Chinggisiana: Compilation of Testimonies of Contemporaries]. Melehin A. (tr.). Moscow: Eksmo, 2009, pp. 17-356. (In Russian)

11. Starinnoe mongol'skoe skazanie o Chingiskhane [Old Mongolian Tale of Chinggis Khan]. Archimandrite Palladij (tr.). Trudy chlenov Rossiyskoy dukhovnoy missii v Pekine [Works of Members of the Russian Spiritual Mission in Beijing]. St. Petersburg, 1866, vol. 4, pp. 3-260. (In Russian)

12. Tataro-mongoly v Azii i Evrope: sbornik statej [The Tatar-Mongols in Asia and Europe: Collected Papers]. Tikhvinskiy S.L. (ed.). Second edition. Moscow: Nauka, 1977. 503 p. (In Russian)

13. Tizengauzen V. Sbornik materialov, otnosyashchikhsya $k$ istorii Zolotoy Ordy, T. 1: Izvlecheniya iz sochineniy arabskikh [Collection of Materials Relating to the Golden Horde's History, Vol. I: Extracts from the Arabic Writings]. St. Petersburg, 1884. xvi + 564 p. (In Russian)

14. Allsen T.T. Mongol Imperialism: The Policies of the Grand Qan Mongke in China, Russia, and the Islamic lands, 1251-1259. Berkeley; Los Angeles; London: University of California Press, 1987. 278 p.

15. Atwood C.P. Encyclopedia of Mongolia and the Mongol Empire. Bloomington: Indiana University, 2004. 678 p. 
16. The Secret History of the Mongols: A Mongolian Epic Chronicle of the thirteenth century. Rachewiltz I. de (tr.). Leiden; Boston: Brill, 2006, vol. 1-2. cxxvii + 1349 p.

17. The Secret History of the Mongols: A Mongolian Epic Chronicle of the thirteenth century. Rachewiltz I. de (tr.). Leiden; Boston: Brill, 2013, vol. 3. xvi + 226 p.

About the author: Igor V. Antonov - Cand. Sci. (History), Senior Research Fellow of the Department of the Archaeological Heritage of the Southern Urals, Institute of Ethnological Studies named after R.G. Kuzeev of the Ufa Federal Research Center of Russian Academy of Sciences (6, Karl Marx Str., Ufa 450077, Russian Federation). E-mail: igan73@yandex.ru

Received March 16, 2021 Accepted for publication May 28, 2021 Published June 29, 2021 


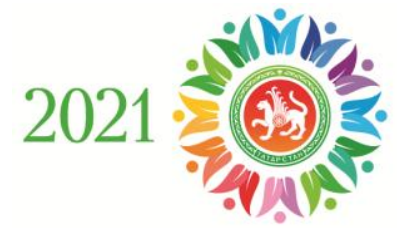

ГОД РОДНЫХ ЯЗЫКОВ И НАРОДНОГО ЕДИНСТВА В РЕСПУБЛИКЕ ТАТАРСТАН

ТАТАРСТАН РЕСПУБЛИКАСЫНДА

ТУГАН ТЕЛЛӘР ҺӘМ ХАЛЫКЛАР БЕРДӘМЛЕГЕ ЕЛЫ

Подготовка и издание журнала осуществлены в рамках

Государственной программы Республики Татарстан «Сохранение национальной идентичности татарского народа (2020-2023 годы)»

The preparation and publication of the journal were carried out within the framework of the State program of the Republic of Tatarstan "Preservation of the National Identity of the Tatar People (2020-2023)"

Институт истории им. Ш.Марджани АН РТ является правообладателем исключительных имущественных прав на свои издания.

Любое использование материала данного издания (размещение в Интернете, перепечатка, переиздание и т.д.), полностью или частично, без разрешения правообладателя запрещается.

The Marjani Institute of History of Tatarstan Academy of Sciences is a holder of exclusive property rights of its own publications. Any use of the material of this publication (publishing online, reprint, republish, etc.), in whole or in part, without permission of the rights holder is prohibited.

На обложке: Фрагмент архитектурной майолики из Сарая-Бату, XIV в.

On the cover: Fragment of architectural majolica from Saray-Batu, 14th century.

Материалы журнала доступны по лицензии Creative Commons "Attribution" («Атрибуция») 4.0 Всемирная (СС ВY 4.0)

All the materials of the "Golden Horde Review" are available under the Creative Commons License "Attribution" 4.0 International (CC BY 4.0)

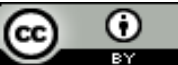


ЗОЛОТООРДЫНСКОЕ ОБОЗРЕНИЕ. 2021. Т. 9, № 2

GOLDEN HORDE REVIEW. 2021, vol. 9, no. 2

Территория распространения - Российская Федерация, зарубежные страны.

Distributed in Russian Federation and foreign countries.

Оригинал-макет подготовлен в Институте истории АН РТ

420111, г. Казань, ул. Батурина, 7А

Подписано в печать 20.06.2021 г. Дата выхода в свет 29.06.2021 г.

Формат $70 \times 108 \frac{1}{16} \quad$ Усл. печ. л. 14,0 Тираж 500 экз.

Свободная цена

Отпечатано с готового оригинал-макета

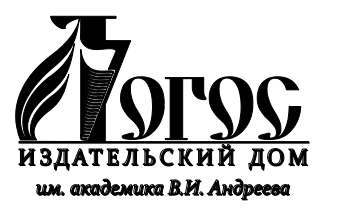

\section{Сайт т}

Института истории Академии наук PT

Татаровед.рф
420108, г. Казань, ул. Портовая, 25a Тел./факс: (843) 231-05-46, 231-08-71, 231-04-19

E-mail: citlogos@mail.ru www.logos-press.ru

ЦИЗОТХ ИИ АН РТ и его издания: http://татаровед.pф/departments/6

Сайт журнала: http://goldhorde.ru 